\title{
FHA ISOLATION AND CHARACTERISATION OF HUMAN EPIDERMAL STEM CELLS
}

\author{
PHILIP H JONES
}

UNIVERSITY COLLEGE LONDON

AND

IMPERIAL CANCER RESEARCH FUND, LONDON

Thesis presented for the degree of

Doctor of Philosophy

in the University of London

March 1995

Internal Supervisor: Prof Lewis Wolpert

External Supervisor: Dr Fiona M Watt 
ProQuest Number: 10106811

All rights reserved

\title{
INFORMATION TO ALL USERS
}

The quality of this reproduction is dependent upon the quality of the copy submitted.

In the unlikely event that the author did not send a complete manuscript and there are missing pages, these will be noted. Also, if material had to be removed, a note will indicate the deletion.

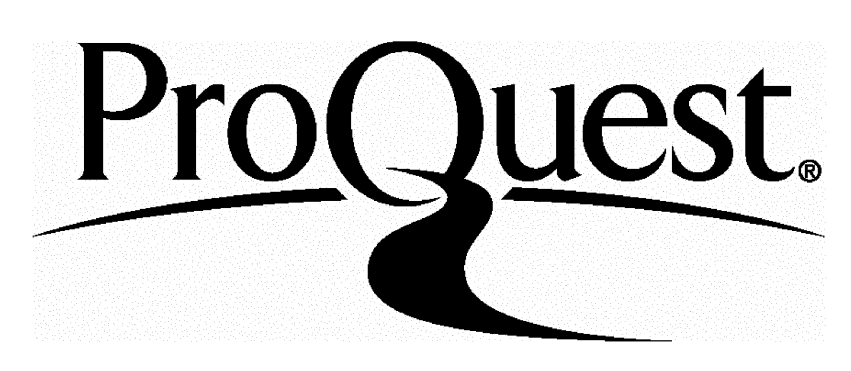

ProQuest 10106811

Published by ProQuest LLC(2016). Copyright of the Dissertation is held by the Author.

All rights reserved.

This work is protected against unauthorized copying under Title 17, United States Code. Microform Edition (c) ProQuest LLC.

\author{
ProQuest LLC \\ 789 East Eisenhower Parkway \\ P.O. Box 1346 \\ Ann Arbor, MI 48106-1346
}


All things counter, original, spare, strange;

Whatever is fickle, freckled (who knows how?)

With swift, slow; sweet, sour; adazzle, dim;

He fathers-forth whose beauty is past change;

Praise Him.

Gerard Manley Hopkins 


\begin{abstract}
The human epidermis is constantly being renewed. Post mitotic terminally differentiated cells are shed from the surface of the epidermis. They are replaced by a population of cells in the basal cell layer of the epidermis that keep proliferating throughout adult life. These cells are called stem cells. The study of stem cells has been hampered by the lack of stem cell markers. Many aspects of keratinocyte differentiation are regulated by members of the integrin family of extracellular matrix (ECM) protein receptors. I set out to investigate if stem cells can be identified on the basis of integrin expression or ECM adhesion.
\end{abstract}

I found that stem cells could be identified in vitro and in vivo by their high level surface expression of the $\beta_{1}$ integrins and their rapid adhesion to extracellular matrix proteins in vitro. These cells were clonogenic in vitro, able to self renew, generated terminally differentiated keratinocytes via a population of committed progenitor cells, reconstituted an epidermis when grafted into nude mice, and exhibited the cell kinetic behaviour predicted for stem cells in vitro and in vivo.

It was possible to localise stem cells in tissue sections stained with anti integrin antibodies. They had a patterned distribution in the epidermis, that varied with body site. The patterning could be reconsitituted in vitro in a manner that suggested it was regulated by interactions between keratinocytes.

I also describe an approach to isolate novel stem cell markers using subtractive hybridisation. This has yielded $50 \mathrm{cDNA}$ clones that await further characterisation. The potential applications of purified viable populations of epidermal stem cells are discussed. 


\section{TABLE OF CONTENTS}

\section{Chapter 1: Introduction}

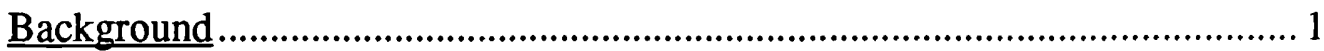

The Structure Of Human Skin ...................................................................... 1

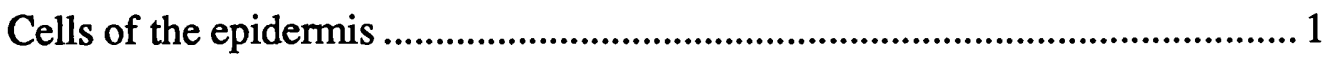

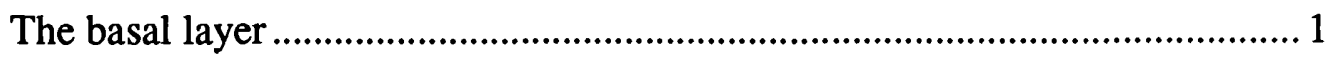

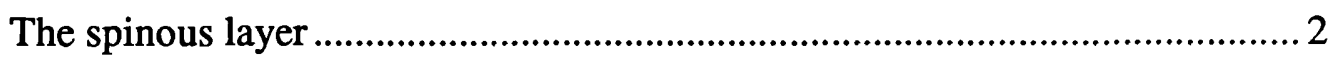

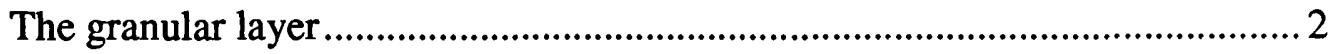

The cornified layer.................................................................................. 3

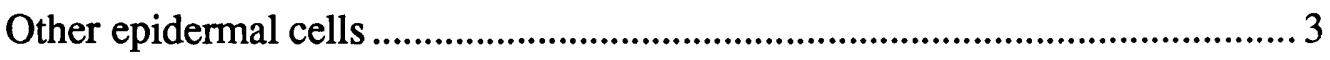

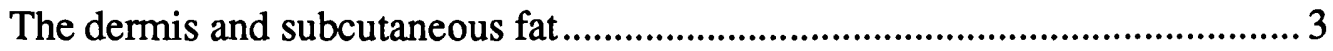

The basement membrane .................................................................... 4

Composition of basement membrane ............................................................ 5

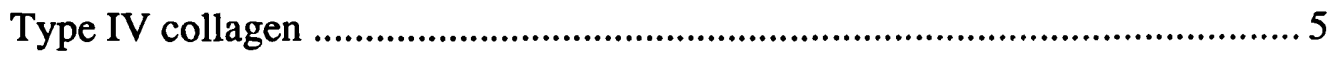

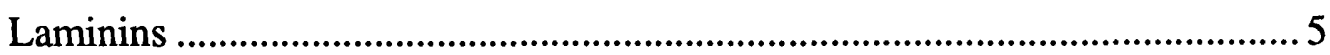

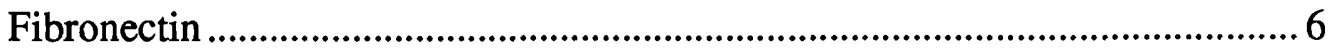

Other basement membrane proteins ........................................................ 6

Origin of the basement membrane ............................................................... 7

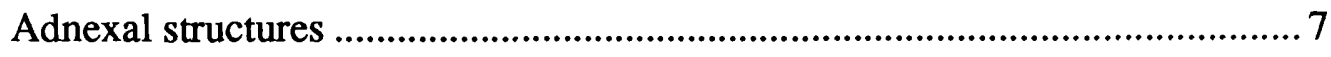

Cell-Cell and Cell-ECM Adhesion in the Epidermis .................................... 9

Cell Matrix adhesion................................................................................. 9

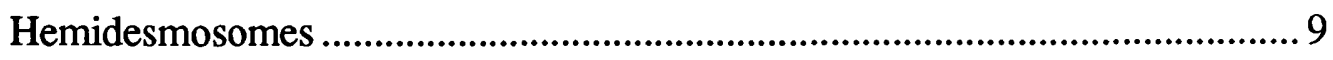

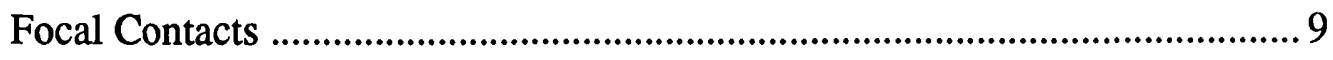

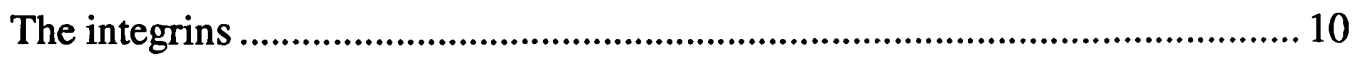

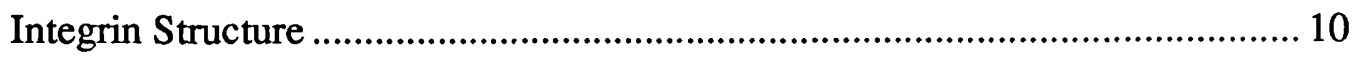

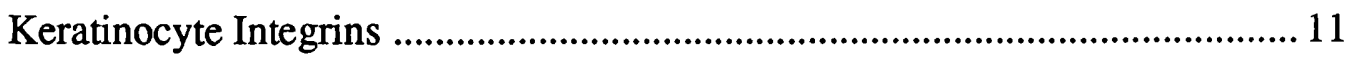

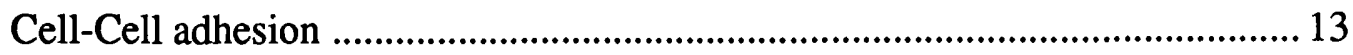




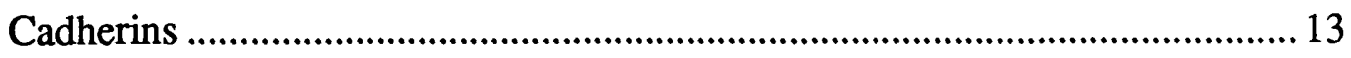

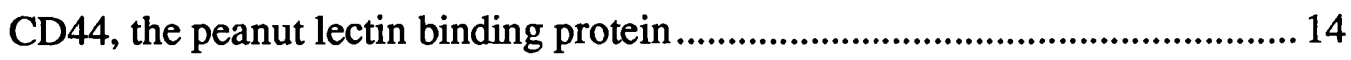

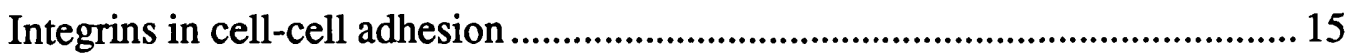

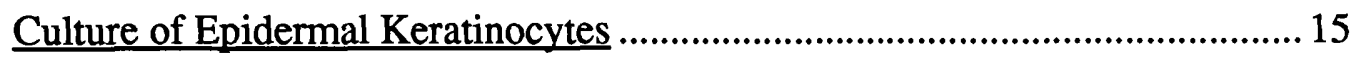

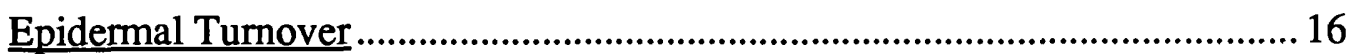

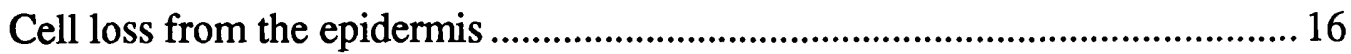

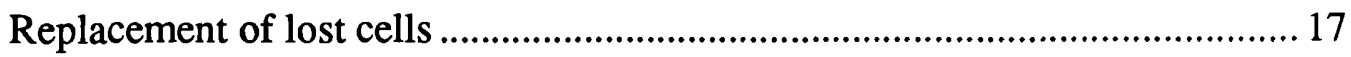

Stem cells and the maintenance of tissue turnover ....................................... 18

Stem cell theory …............................................................................................. 18

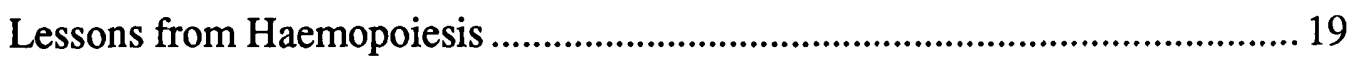

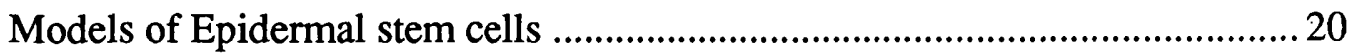

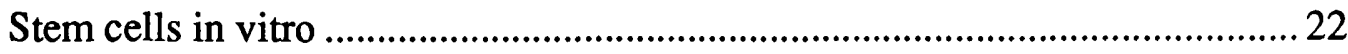

Stem cells in Hair Follicles ......................................................................... 23

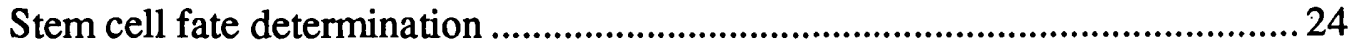

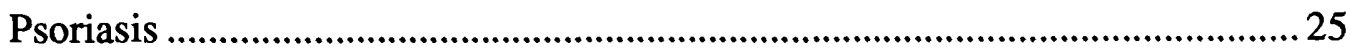

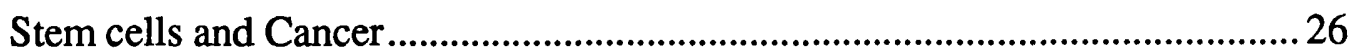

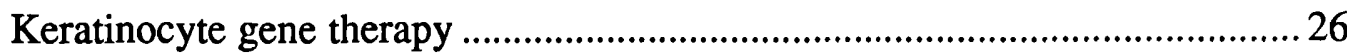

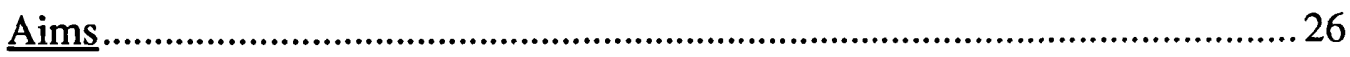

\section{Chapter 2: Materials and Methods}

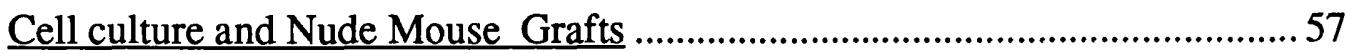

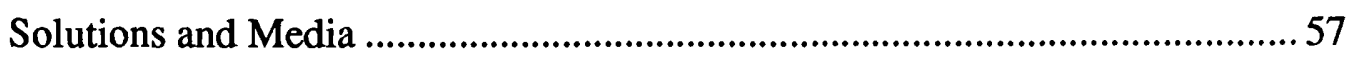

Phosphate Buffered Saline (PBS, ICRF) ..................................................... 57

Trypsin Solution (5X stock, ICRF) …......................................................... 57

EDTA solution (Versene, ICRF) ................................................................... 57

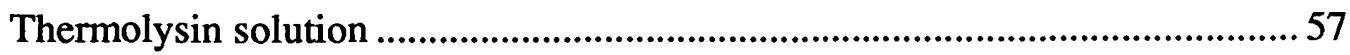

Keratinocyte growth medium (FAD/HICE/FCS) ............................................5 58

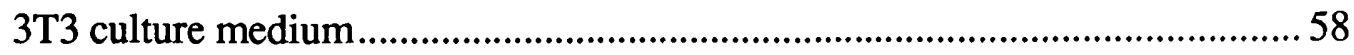

Medium for suspension culture of keratinocytes ............................................5 58 


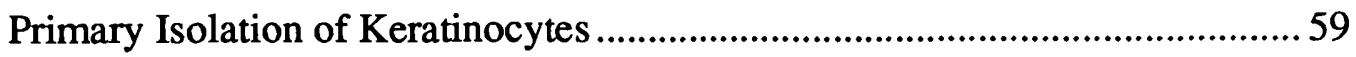

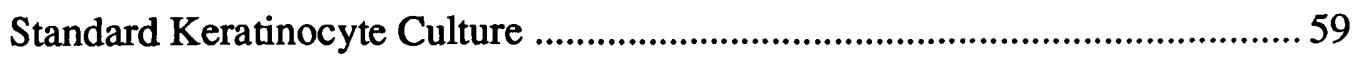

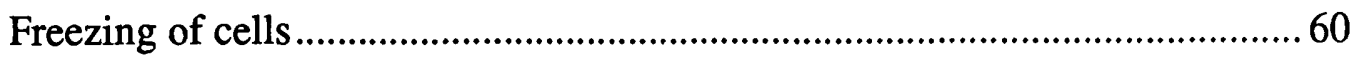

Grafting cultured keratinocytes into nude mice...........................................6 60

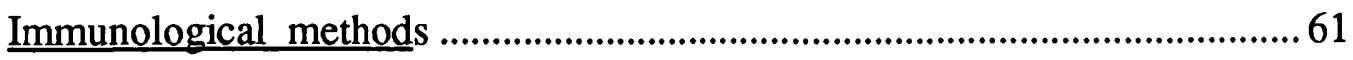

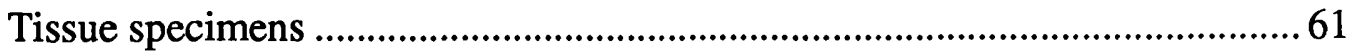

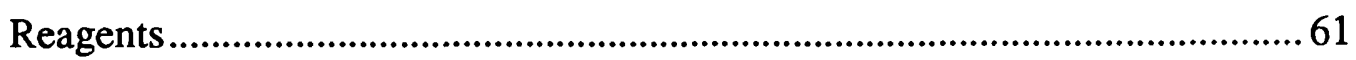

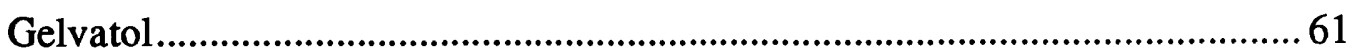

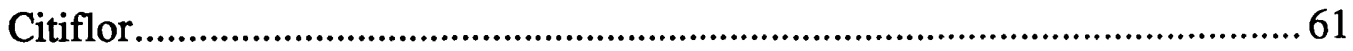

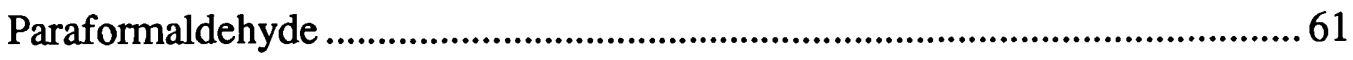

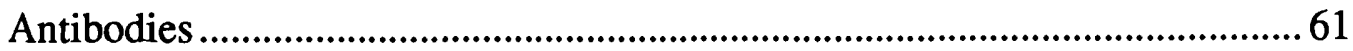

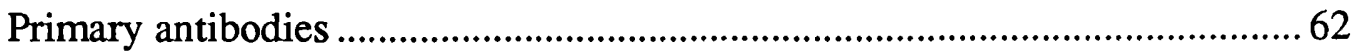

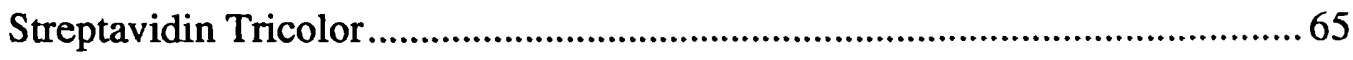

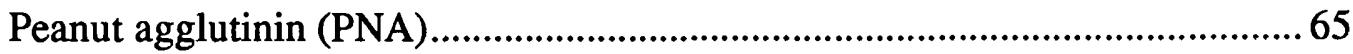

Biotinylation of antibodies .............................................................................6 65

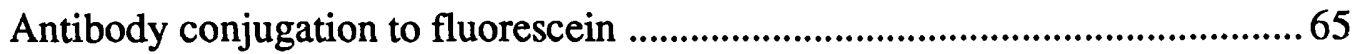

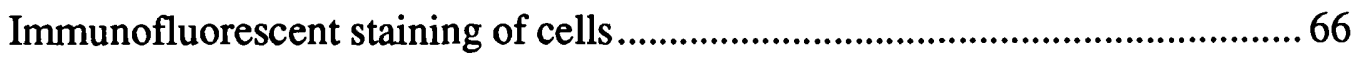

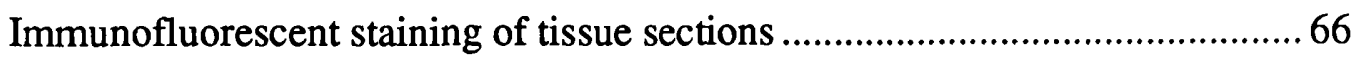

Quantification of fluorescence on tissue sections and keratinocyte cultures ....67

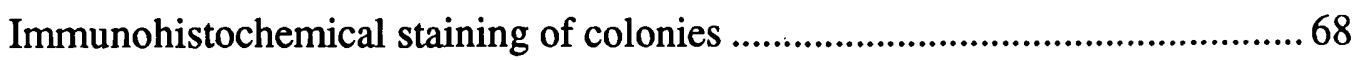

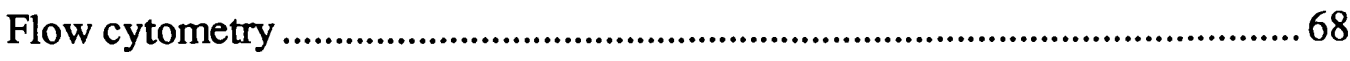

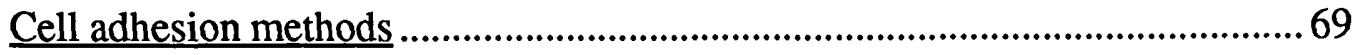

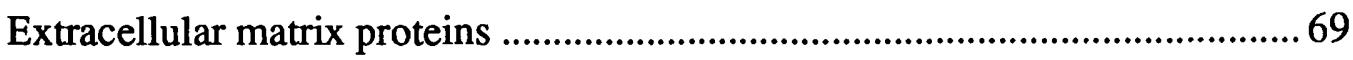

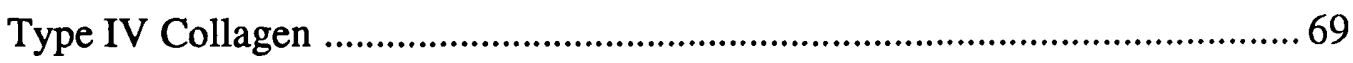

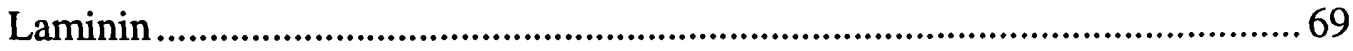

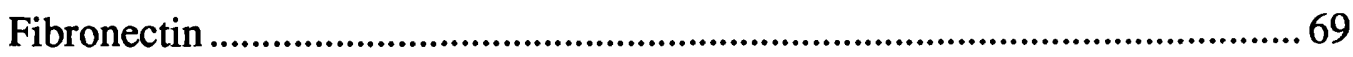

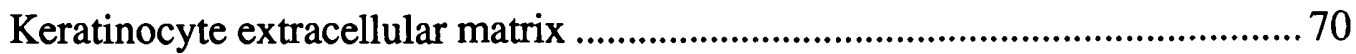

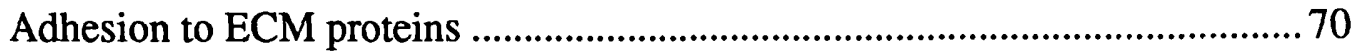


Coating dishes and plates....................................................................... 70

Adhesion blocking experiments .................................................................. 70

Determination of colony forming efficiency ............................................... 70

Suspension induced terminal differentiation ................................................. 71

Cell fate studies

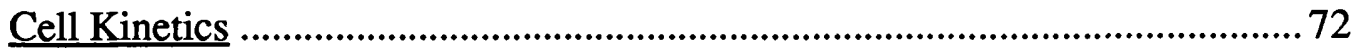

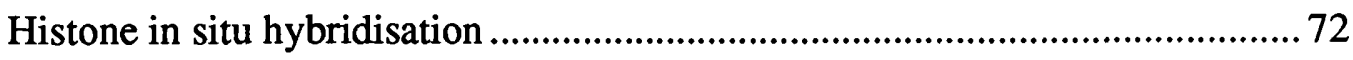

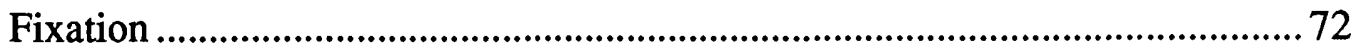

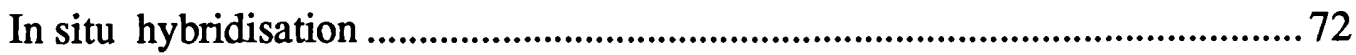

Tritiated thymidine incorporation in keratinocyte cultures ............................... 74

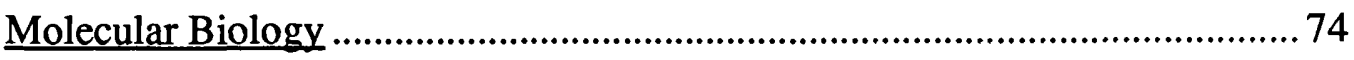

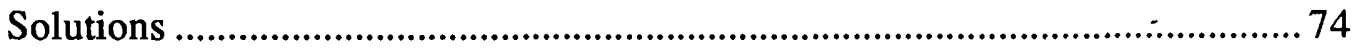

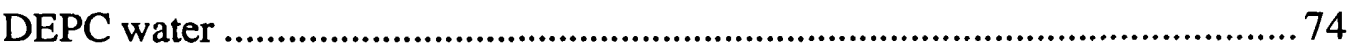

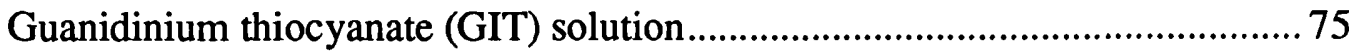

Caesium chloride /EDTA solution-(CsCl2/EDTA) ...................................... 75

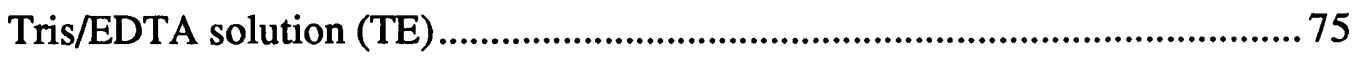

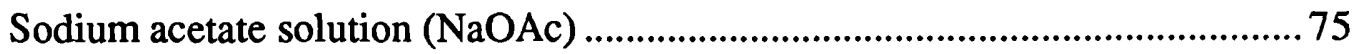

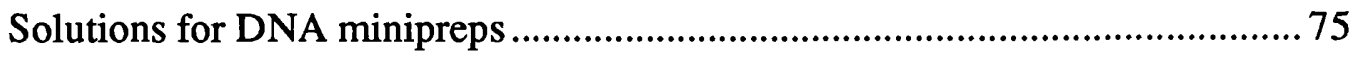

Ammonium acetate solution (NH4OAc) ....................................................... 75

Tris-Acetate EDTA buffer (TAE) ................................................................ 76

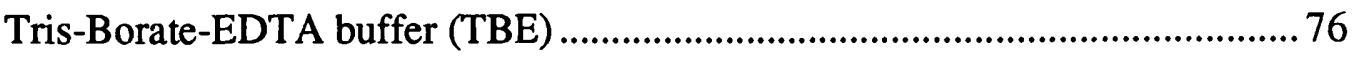

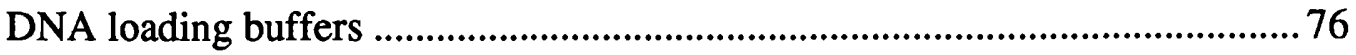

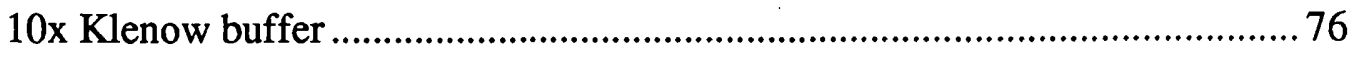

Solutions for replica plating on Hybond $\mathrm{N}$ filters .......................................... 76

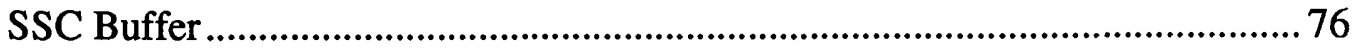

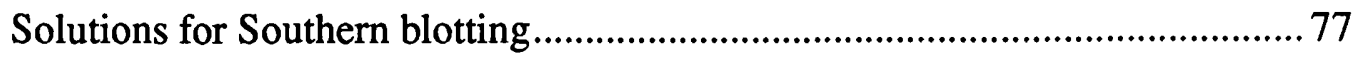

Solutions for polyacylamide gel electrophoresis of protein ........................... 77

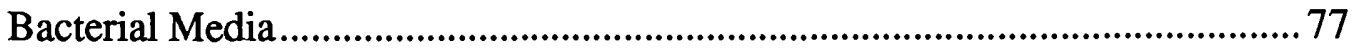

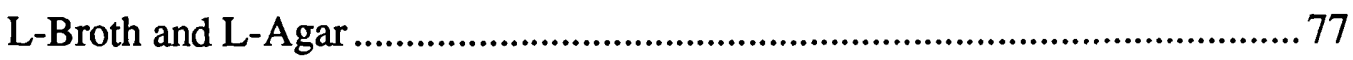




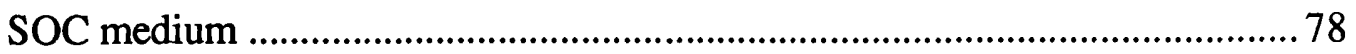

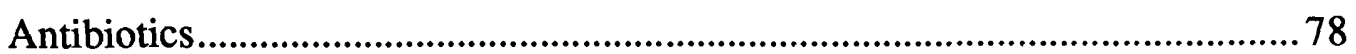

Molecular Biology- General procedures ...........................................................

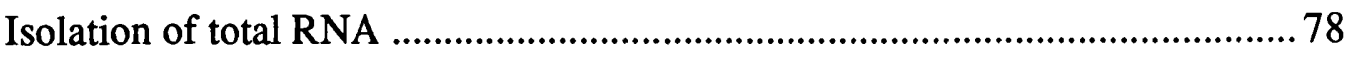

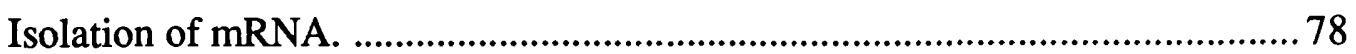

Phenol/chloroform extraction ............................................................................ 78

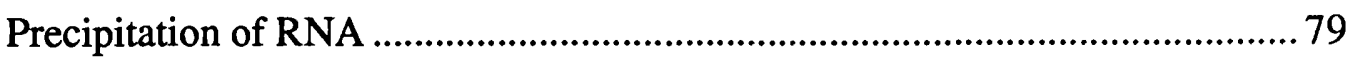

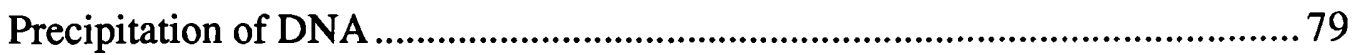

Quantification of nucleic acids in solution ........................................................ 79

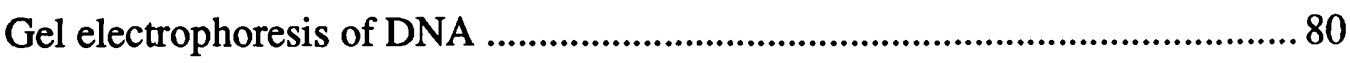

Alkaline Gel electrophoresis of single stranded DNA ………………………....... 80

Radioactive labelling of molecular weight markers ........................................... 80

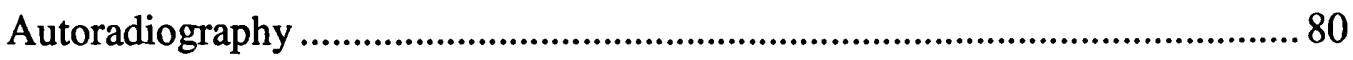

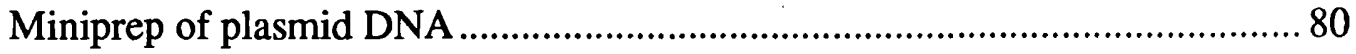

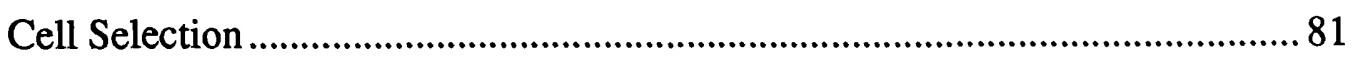

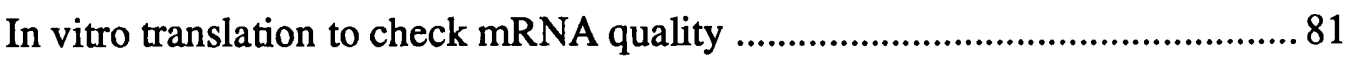

cDNA synthesis and ligation ............................................................................ 82

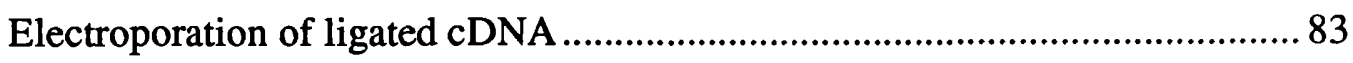

Assessment of cDNA library quality ………………………............................ 83

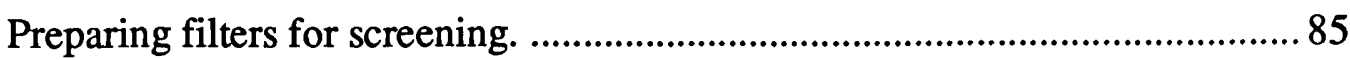

Preparation of a subtracted probe .................................................................... 85

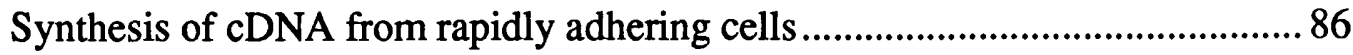

Determination of first strand reaction yield ....................................................... 86

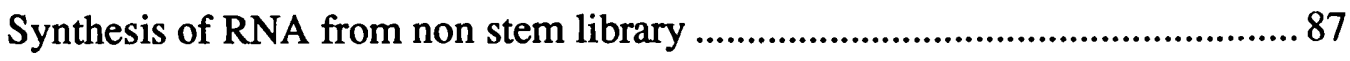

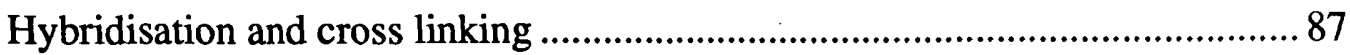

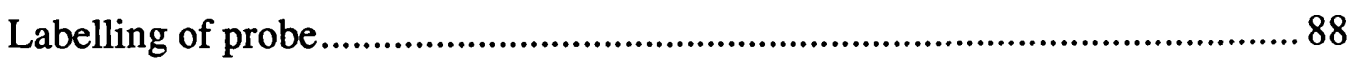

Screening of stem cell library .............................................................................. 88

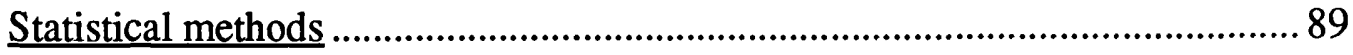




\section{Chapter 3: Epidermal Stem cells in vitro}

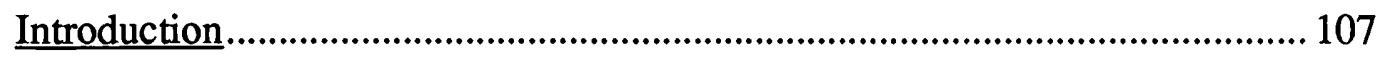

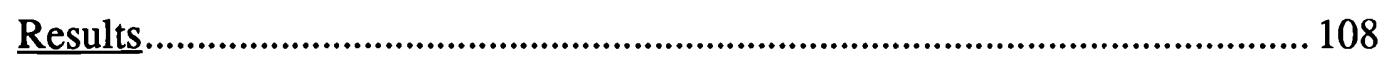

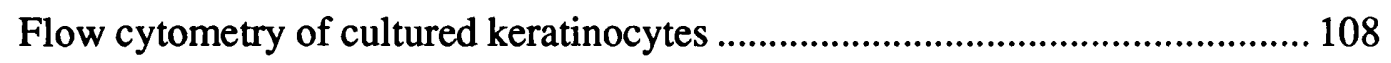

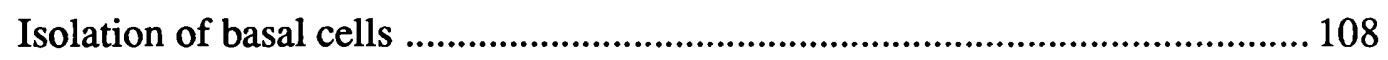

Integrin expression in keratinocytes ................................................................. 109

Colony forming efficiency (CFE) of basal cells fractionated on the basis of

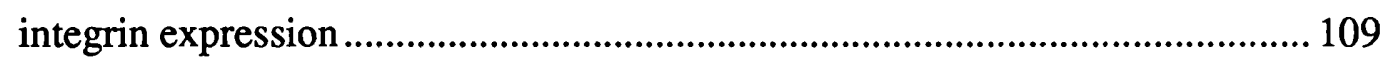

CFE of keratinocytes that adhere most rapidly to extracellular matrix

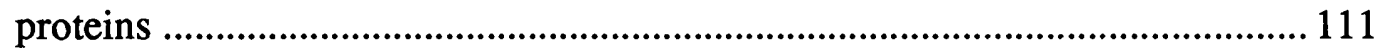

Differentiation and self renewal of rapidly adherent cells.................................. 113

Suspension culture of cells with high colony forming efficiency ..................... 113

Tritiated thymidine incorporation by integrin-bright cells in post confluent

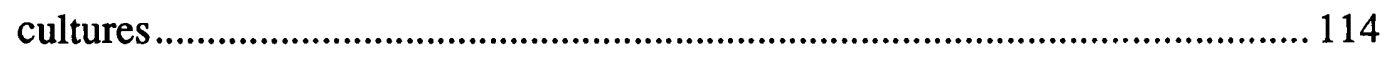

Fate of cells which attach slowly to ECM ....................................................... 114

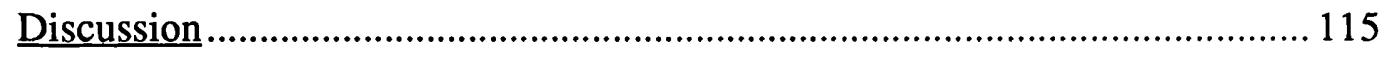

\section{Chapter 4; Epidermal Stem cells in vivo}

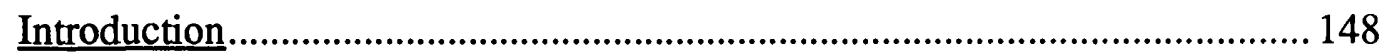

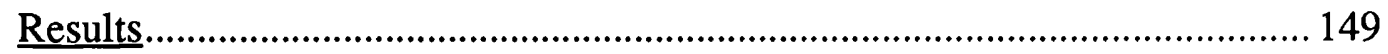

Variation of integrin levels within the basal layer of the epidermis................... 149

Isolation and cultivation of integrin-bright and -dull cells ................................. 152

Rapidly adhering keratinocytes are able to reconstitute an epidermis in vivo .. 153

Stem cell patterning in epidermis grafted into nude mice .................................... 153

The fate of slowly adhering basal cells............................................................... 153

Cell cycle kinetics of basal keratinocytes .......................................................... 154

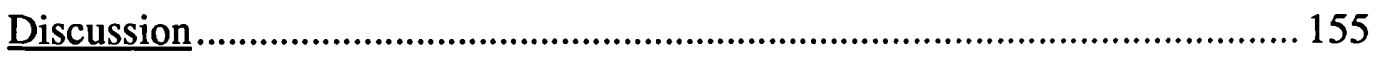




\section{Chapter 5: Stem cell fate and Patterning}

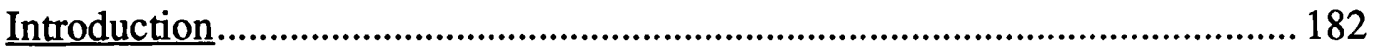

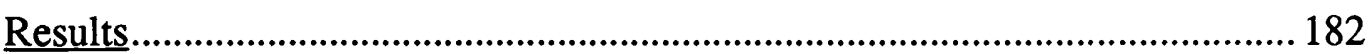

Reconstitution of stem cell patterning in vitro ................................................... 182

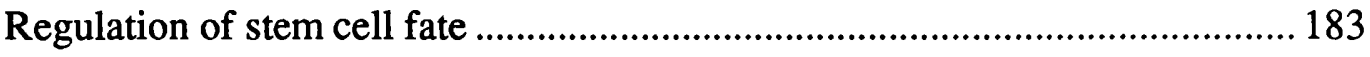

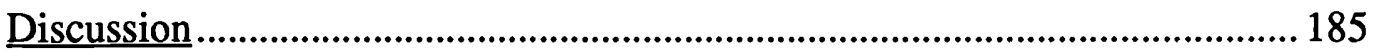

\section{Chapter 6: Strategy for identification of novel stem cell markers} and regulatory genes

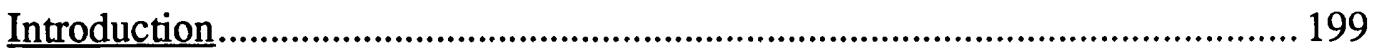

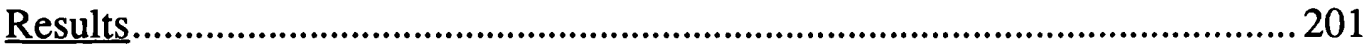

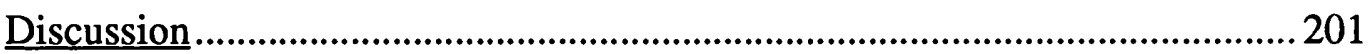

\section{Chapter 7: general discussion}

Stem cell fate

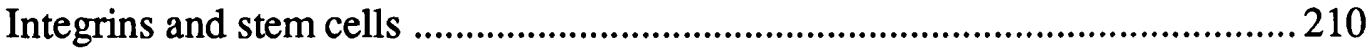

Novel stem cell markers ...................................................................................... 211

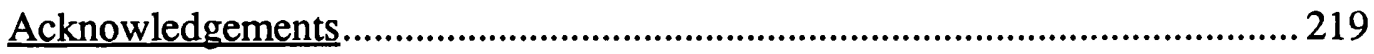

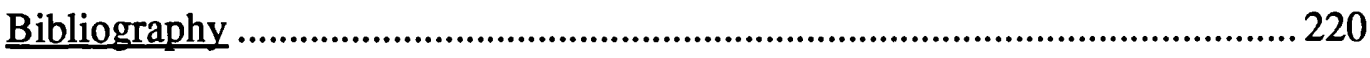




\section{LIST OF TABLES}

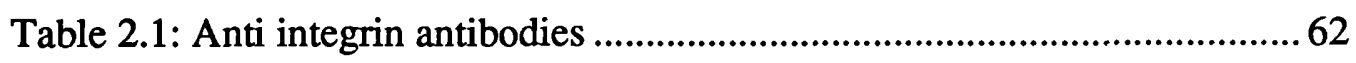

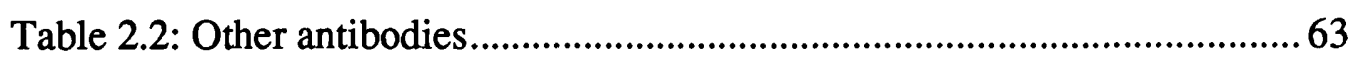

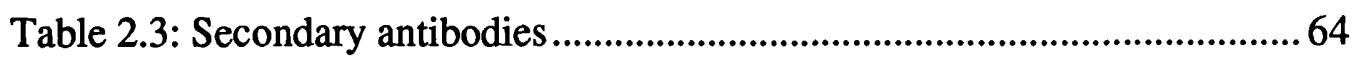

Table 2.4: cDNA libraries made with cultured keratinocytes .......................... 85

Table 3.1: Involucrin expression and CFE of keratinocytes sorted on the

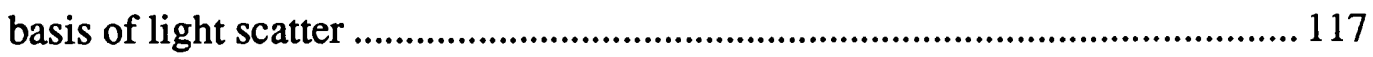

Table 3.2: Cell size and intensity of $\alpha_{2}$ integrin subunit staining in FACS

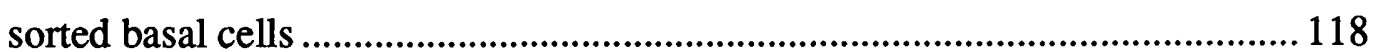

Table 4.1: Integrin expression in basal cells in different body sites................. 158

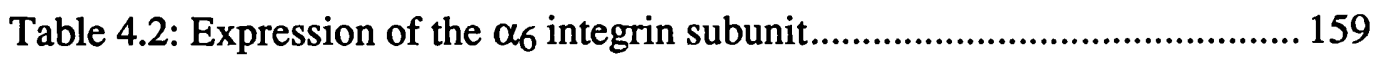

Table 4.3: Distribution of $S$ phase cells in the basal epidermal layer as determined by in situ hybridisation with histone probes ................................ 160

Table 5.1: Integrin-bright patches formed in sheets of cultured keratinocytes comparison of unselected and rapidly adhering cells ...................................... 186

Table 5.2: Integrin-bright patches formed in sheets of cultured keratinocytes . 187 


\section{LIST OF FIGURES}

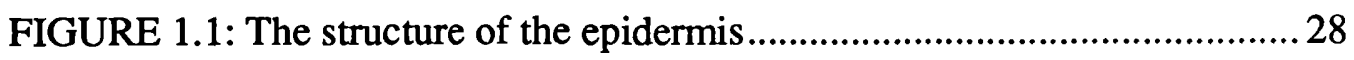

FIGURE 1.2: The structure of the hemidesmosome ......................................30

FIGURE 1.3: The arrangement of dermal papillae and rete ridges in the

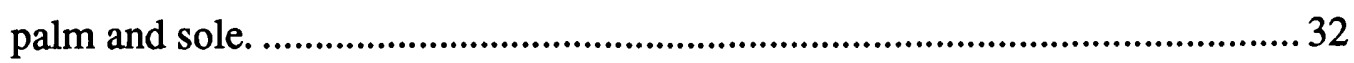

FIGURE 1.4: Dermal papillae in thin skin. .................................................... 34

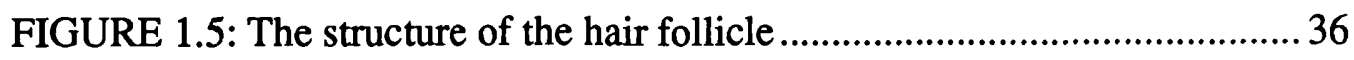

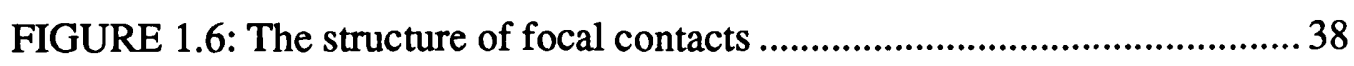

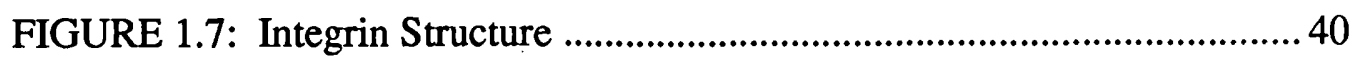

FIGURE 1.8: Structural relationships between integrin $\alpha$ subunits ................. 42

FIGURE 1.9: The development of models of tissue specific stem cells .......... 44

FIGURE 1.10: A current model of haempoietic progenitor cells ......................46

FIGURE 1.11: Behaviour of committed erythroid progenitor cells ................. 48

FIGURE 1.12: Use of radiobiological data to estimate the number of

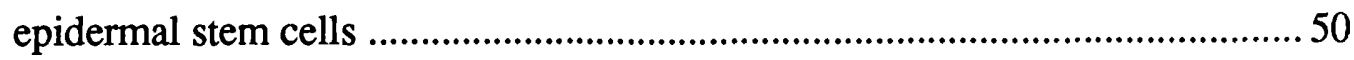

FIGURE 1.13: The epidermal proliferative unit...........................................52

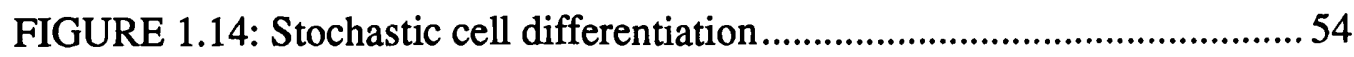

FIGURE 2.1: Method for grafting cultured human keratinocytes into nude

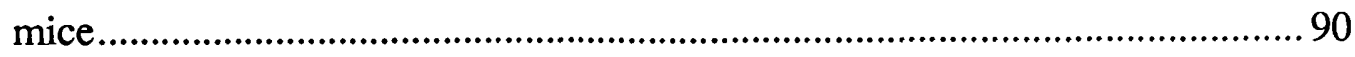

FIGURE 2.2: In vitro translation of RNA isolated from keratinocytes............ 92

FIGURE 2.3: Outline of method for construction of oligo dT primed

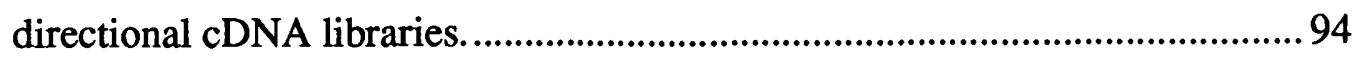

FIGURE 2.4: Method of cDNA library construction ......................................96

FIGURE 2.5: cDNA synthesis, size fractionation and ligation into plasmid. ...98

FIGURE 2.6: Plasmid Map of pSport 1 (Gibco-BRL) .................................... 100

FIGURE 2.7: The multiple cloning site of pSport ........................................... 102

FIGURE 2.8: Example of analysis of covariance........................................... 104 
FIGURE 3.1: Flow cytometry of cultured keratinocytes.

FIGURE 3.2: $\beta_{1}$ Integrin subunit expression and keratinocyte

differentiation.

FIGURE 3.3: $\beta_{1}$ Integrin subunit expression and keratinocyte

differentiation.

FIGURE 3.4: Expression of $\alpha_{2}, \alpha_{3}, \alpha_{5}$ and $\alpha_{6}$ integrin subunits and

keratinocyte differentiation.

FIGURE 3.5: Effect of suspension-induced differentiation on integrin

expression

FIGURE 3.6: Integrin expression and CFE in basal keratinocytes

FIGURE 3.7: Appearance of colonies formed by basal keratinocytes

FIGURE 3.8: CFE of basal keratinocytes sorted simultaneously for $\alpha_{2}, \alpha_{3}$

and $\alpha_{5}$ integrin subunit expression

FIGURE 3.9: CFE of basal keratinocytes adhering to ECM proteins at

different rates

FIGURE 3.10: CFE of unfractionated basal cells placed in suspension

culture for 0 to 5 hours

FIGURE 3.11: Self renewal and differentiation of rapidly adherent cells

FIGURE 3.12: Suspension induced differentiation of rapidly adherent and unselected basal cells

FIGURE 3.13: Cell cycle kinetics and integrin expression in post confluent

keratinocyte cultures.

FIGURE 3.14: Fate of cells that did not adhere rapidly to type IV collagen .... 145

FIGURE 4.1: Quantification of integrin levels by confocal microscopy 161

FIGURE 4.2: Variation in integrin levels in human skin from different body

sites 163

FIGURE 4.3: Relationship between integrin expression and CFE in keratinocytes isolated directly from neonatal foreskins 165 
FIGURE 4.4: Blocking adhesion of freshly isolated foreskin keratinocytes to type IV collagen with anti integrin antibodies.............................................. 167

FIGURE 4.5: Grafting of rapidly adherent cells onto nude mice .................... 169

FIGURE 4.6: Rapidly adherent cells reconstitute epidermis in nude mice ....... 171

FIGURE 4 .7: Fate of individual cells isolated from foreskin epidermis ......... 173

FIGURE 4.8: In situ hybridisation controls ................................................... 175

FIGURE 4.9: Distribution of S phase cells within the epidermis..................... 177

FIGURE 4.10: Implications of stem cell patterning for cell migration in the

epidermis

FIGURE 5.1: Integrin expression in cultured epidermal sheets ...................... 188

FIGURE 5.2: Pattern formation in cultured keratinocytes ............................... 190

FIGURE 5.3: Colony containing multiple integrin bright and dull patches..... 192

FIGURE 5.4: Analysis of PKH 26 dilution by FACS ...................................... 194

FIGURE 5.5: Appearance of PKH26 labelled colonies .................................. 196

FIGURE 6.1: Production of a subtracted probe..............................................202

FIGURE 6.2: Primary Screening of 0-20 cell library with subtracted probe .... 204

FIGURE 6.3: Secondary screening of positive isolates from primary screen ... 206

FIGURE 7.1: Stem cells, transit cells and committed cells in the epidermis ....214

FIGURE 7.2: Possible interactions between integrins, cadherins and the Wnt

signalling pathway 216 


\section{CHAPTER 1 \\ INTRODUCTION}

\section{Background}

The human epidermis is constantly being renewed. Post mitotic terminally differentiated cells are shed from the surface of the epidermis. They are replaced by a population of cells in the basal cell layer of the epidermis that keep proliferating throughout adult life. These cells are called stem cells. The study of stem cells has been hampered by the lack of stem cell markers. Many aspects of keratinocyte differentiation are regulated by members of the integrin family of extracellular matrix (ECM) protein receptors. I set out to investigate if stem cells can be identified on the basis of integrin expression or ECM adhesion.

\section{THE STRUCTURE OF HUMAN SKIN}

The nature of the skin varies with body site. Thick, hairless skin is found on the palms and soles. Thin, hair bearing skin covers most of the rest of the body. Histologically adult skin can be divided into three layers. The outermost layer is the epidermis, the middle layer is the dermis and the deepest layer is the subcutaneous fat (Ham and Cormack 1979). The epidermis is separated from the dermis by a basement membrane.

\section{Cells of the epidermis}

The epidermis consists of layers of epidermal keratinocytes, although it also contains three other cell types with specialist functions. Keratinocytes are arranged in four histologically distinct layers (Figure 1.1) (Odland 1991; Holbrook 1994). The cells in each layer show clear morphological differences.

\section{The basal layer}

Basal keratinocytes are cuboidal cells with a diameter of 6-8 $\mu \mathrm{m}$. The cytoplasm contains the distinctive network of keratin intermediate filaments which give keratinocytes their name. Keratin filaments are heterodimers of acidic (type I) and basic (type II) polypeptides. The subunits expressed in basal cells are keratin 5 and keratin 14 (Morely and Lane 1994). The arrangement of the keratin filaments resembles scaffolding; they form a cage round the nucleus from which filaments radiate to the cell membrane (Sun and Green 1978). The importance of the network 
of keratin filaments in basal cells is demonstrated in the inherited disease

Epidermolysis bullosa simplex. This disease is caused by mutations in keratin 5 and 14 genes which result in a failure of keratin filament assembly. The basal cells are fragile and are sheared apart when exposed to minimal mechanical stress, forming blisters. (Vassar et al. 1991; Lane et al. 1992; Fuchs 1994).

At the basal surface of basal keratinocytes the keratin filaments run into structures called hemidesmosomes (Figure 1.2, discussed below), which are only found in the basal layer (Briggaman and Wheeler 1975). At the lateral and apical surfaces of the cell the keratin filaments insert into structures called desmosomes which are involved in cell-cell adhesion and are found in all layers of the epidermis (Schwartz et al. 1990; Legan et al. 1992).

\section{The spinous layer}

The spinous layer consists of the 4-5 layers of keratinocytes above the basal layer. The cells become progressively larger the further they are from the basal layer. The spines which give this layer its name are the desmosomal junctions between cells (Holbrook 1994). The keratins expressed in the spinous layer are keratin 1 and keratin 10 in hair bearing skin and keratins 1 or 2 and keratin 9 in the palm and sole (Morely and Lane 1994). Mutations in spinous layer keratins cause blistering diseases; bullous congenital ichthyosiform erythroderma in hair bearing skin, and epidermolytic palmoplantar keratoderma in the palms and soles (Cheng et al. 1992; Reis et al. 1994).

The uppermost cells in the spinous layer contain precursors of the cornified layer. Membrane bound lamellar granules contain lipids destined to fill the inter cellular spaces between keratinocytes in the cornified (Wertz and Downing 1991; Holbrook 1994). The cytoplasm of spinous layer cells contains soluble protein precursors of the a structure known as the cornified envelope, which is assembled in the cornified layer. These proteins are involucrin (Rice and Green 1979; Banks Schlegel and Green 1981), cornifin, keratolinin and pancornulin (Simon 1994).

\section{The granular layer}

The granular layer overlies the spinous layer. It is 2-3 cells thick in hair bearing skin and thicker in the palms and soles. Keratinocytes in this layer are identified by the presence of electron dense keratohyalin granules (Holbrook 1994), which 
contain the proteins loricrin and profilaggrin (Dale et al. 1994). The lamellar granules fuse to the plasma membrane and discharge their contents into the intercellular space. The granular layer is 3-4 cells thick in thin skin and thicker in palms and soles (Holbrook 1994).

\section{The cornified layer}

The cornified layer is the outermost layer of the epidermis. It functions as a flexible impermeable barrier to protect the body from the environment (Polakowska and Goldsmith 1991; Wertz and Downing 1991). It is 10-30 cell layers thick in thin skin and hundreds of cell layers thick in the palms and soles (Holbrook and Odland 1974; Potten 1975; Mackenzie et al. 1981).

The keratinocytes of the cornified layer are known as squames. They are flattened, plate-like cells, $40 \mu \mathrm{m}$ in diameter but only $0.5 \mu \mathrm{m}$ in thickness (Odland 1991). The cytoplasm is filled with keratin filaments. The nucleus and other cell organelles are degraded as cells enter the comified layer (Karasek 1988; Odland 1991; Holbrook 1994). The cornified envelope of cross linked protein lies beneath plasma membrane. Sheets of squames are continually shed from the epidermal surface.

\section{Other epidermal cells}

The epidermis contains three cell types in addition to keratinocytes. Melanocytes synthesise melanin pigment, Merkel cells function as sensory receptors and Langerhans cells have a role in antigen presentation to the immune system (Hauser et al. 1991; Jimbow et al. 1991; Munger 1991; Haake and Polakowska 1993).

\section{The dermis and subcutaneous fat}

The dermis is the layer of connective tissue that lies between the epidermis and the subcutaneous fat (Odland 1991). The junction between the epidermis and the dermis undulates. Regions where the epidermis projects down into the dermis are called rete ridges, and areas where the dermis projects into the epidermis are called dermal papillae (Figure 1.3). Each dermal papilla contains a blood capillary loop and a terminal lymphatic vessel (Ryan 1991). In palm and sole there are 2 types of rete ridges. Deep rete ridges are interspersed with shallow ridges, where the ducts from sweat glands enter the epidermis (Chacko and Vaidya 1968; Lavker and Sun 1982). The term dermal papillae is a misnomer in palm and sole, where the 
epidermal-dermal junction is arranged in longitudinal ridges (Chacko and Vaidya 1968). In most other body sites, however, the dermis forms true papillae (Figure 1.4) (Briggaman et al. 1991).

The dermis is divided into two regions. The papillary dermis is the superficial part of the dermis that forms the dermal papillae. The deeper part of the dermis is called the reticular dermis. This comprises dense collagenous and elastic tissue containing dermal fibroblasts and mast cells (Tharp 1991). It is traversed by nerves and blood vessels. (Odland 1991).

\section{The basement membrane}

Basal keratinocytes are separated from the dermis by the epidermal basement membrane (Briggaman et al. 1991). Conventional electron microscopy of the basement membrane reveals 3 layers; from the epidermal side inwards these are termed the lamina lucida, lamina densa and the reticular layer (Briggaman and Wheeler 1975).

The lamina lucida is an electron lucent area lying between the basal surface of epidermal keratinocytes and the lamina densa (Briggaman and Wheeler 1975). The only discernible structures in the lamina lucida are fine filaments, known as anchoring fibrils, that run from hemidesmosomes to the lamina densa (Briggaman and Wheeler 1975). The lamina lucida is not seen in specimens prepared by cryofixation (Chan et al. 1993).

The lamina densa is an electron dense layer that runs parallel to basal cell membrane of basal keratinocytes. Viewed by scanning electron microscopy the epidermal surface of the lamina densa undulates, forming micro ridges and valleys (Mihara et al. 1992). At higher magnification the surface of each micro ridge is seen to be studded with discrete particles that contain type IV collagen. Partial trypsinisation to remove the surface structures reveals that the interior of the lamina densa consists of a 3 dimensional array of microfilaments (Mihara et al. 1992).

The reticular layer of the basement membrane is an electron lucent zone containing fibres running from the dermis to insert in the lamina densa, including the anchoring fibrils that connect the hemidesmosomes to the dermis. 


\section{Composition of basement membrane}

Several proteins interact to form the basement membrane, which in vivo probably lies against the basal surface of keratinocytes (Chan, et al. 1993).

\section{Type IV collagen}

In common with all other basement membranes the epidermal lamina densa contains abundant type IV collagen (Foidart and Yaar 1981; Briggaman, et al. 1991; Mihara et al. 1992). The molecule is a trimer. The isoform found in human epidermis, $[\alpha 1(\mathrm{IV})]_{2} \alpha 2(\mathrm{IV})$ is also found in many other basement membranes (Yurchenco and Schittney 1990; Yurchenco and O'Rear 1994). The molecule is very flexible and self assembles in vitro to form a complex network by interacting with other collagen molecules at carboxyl and amino terminal ends and by lateral associations (Yurchenco and Furthmayer 1984; Yurchenco and Schittney 1990).

The $\alpha 5$ (IV) collagen subunit is also found in the epidermal basement membrane, though its functional significance is unclear as mutations in the $\alpha 5$ (IV) gene in $\mathrm{X}$ linked Alport's Syndrome are not associated with any alteration in epidermal phenotype (Yoshioka et al. 1994).

\section{Type VII Collagen}

Type VII collagen forms the anchoring fibrils seen traversing the reticular layer of the basement membrane. The anchoring fibrils link the type IV collagen in the basement membrane to structures called anchoring plaques, composed of both type IV and type VII collagens (Figure 1.2) (Keene et al. 1987; Burgeson 1993). Mutations in type VII collagen result in the severe blistering disorder epidermolysis bullosa dystrophica (Ryynanen et al. 1992) in which anchoring fibrils are absent (Tidman and Eady 1985) and the epidermis becomes detached from the dermis beneath the lamina densa at sites of friction such as the palms and soles.

\section{Laminins}

The laminins are composed of 3 polypeptide subunits. The classification of laminin subunits and isoforms has recently been revised, the laminins are numbered and the subunits termed $\alpha, \beta$ and $\gamma$ (Burgeson et al. 1994). Several forms of laminin are found in the epidermal basement membrane. 
Laminin 1 is abundantly expressed in the epidermal lamina densa in vivo (Sollberg et al. 1992). It consists of 3 subunits, $\alpha 1, \beta 1$ and $\gamma 1$, arranged to form a cross shaped molecule (Yurchenco and Schittney 1990). Like type IV collagen, it is able to self assemble into a multi molecular network in vitro (Yurcheno et al. 1992). Laminin $2,(\alpha 2, \beta 2, \gamma 1)$, formerly known as merosin, is detectable in the epidermal basement membrane but expression is at a low level (Sollberg et al. 1992).

Laminin 5, previously known as epiligrin or kalinin, is a variant laminin ( $\alpha 3, \beta 3, \gamma 2$ subunits), that was first found in epidermal basement membranes (Verrando et al. 1988; Carter et al. 1991; Rousselle et al. 1991). It forms the anchoring filaments that are seen to run from the hemidesmosomes on the basal surface of basal keratinocytes into the basement membrane (Figure 1.2). Mutations in laminin 5 cause Herlitz's junctional epidermolysis bullosa in which basal cells are sheared off the basement membrane forming blisters (Verrando et al. 1991; Aberdam et al., 1994; Pulkkinen et al 1994).

Laminin 6 , formerly called $\mathrm{k}$-laminin, is composed of $\beta 1$ and $\gamma 1$ chains probably associated with an $\alpha 3$ subunit. It is found in the epidermal basement membrane and in the basement membranes of the lung and intestine (Marinkovitch et al. 1992).

\section{Fibronectin}

Fibronectin is a ubiquitous $540 \mathrm{kD}$ glycoprotein composed of two identical subunits found in plasma and serum and widely distributed in tissues. Each subunit contains domains that bind other fibronectin dimers, collagen types I and IV, heparin and the cytokine transforming growth factor $\beta$ (Fava and McClure 1987; Hynes 1989; Potts and Campbell 1994). Fibronectin can self assemble into fibrils in vitro (Schwartzbauer 1991). It is abundantly expressed in the dermis and at the dermalepidermal junction. In normal adult skin there is little fibronectin expressed in the basement membrane itself (Fleischmayer and Timpl 1984; Couchman et al. 1990).

\section{Other basement membrane proteins}

Proteoglycans are a large family of proteins that all contain one or more glysaminoglycan side chains linked to a core protein. Secreted proteoglycans are found in all basement membranes and tissue matrices (Hassel et al. 1986; Kjellen and Lindahl 1991). The epidermal basement membrane contains several proteoglycans, including perlecan, versican and heparan sulphate proteoglycans 
(HSPG), (Murdoch et al. 1994; Zimmermann et al. 1994; Caughman et al. 1987; Van den Born et al. 1994). One function of these molecules is to bind growth factors such as fibroblast growth factor (FGF) and platelet derived growth factor, and to present them to growth factor receptors at the cell surface (Aviezer et al. 1994).

Nidogen, also known as Entactin, is a dumbbell shaped $150 \mathrm{kD}$ glycoprotein, found in the basement membrane of the epidermis and other sites (Caughman et al. 1987; Yurchenco and O'Rear 1994). It has binding sites for type IV collagen, laminin 1, perlecan core protein and the basement membrane glycoprotein fibulin (Caughman et al. 1987; Fox et al. 1991; Yurchenco and O'Rear 1994). Nidogen is thought to play a role in the assembly of basement membrane proteins into a three dimensional network in vivo (Yurchenco and Schittney 1990; Yurchenco and O'Rear 1994).

\section{Origin of the basement membrane}

The proteins in the basement membrane seem to be secreted by both keratinocytes and fibroblasts (Marinkovich et al. 1993). In co-culture experiments with bovine keratinocytes and human fibroblasts a basement membrane was only formed when both cell types were present together. Using species specific antibodies it was possible to determine that the keratinocytes contributed type IV collagen, type VII collagen, laminins 1,5 and 6 and basement membrane associated HSPG in the presence or absence of fibroblasts. The fibroblasts produced laminin 1 and type IV and type VII collagen. Studies of basement membrane protein synthesis in mouse embryos also support the idea of epithelial/mesenchymal co-operation in basement membrane production (Thomas and Dziadek 1993).

\section{Adnexal structures}

Hair follicles are found all over the body apart from the palms, soles and foreskin. The basic structure of a follicle is shown in Figure 1.5. The follicle is enveloped in a connective tissue sheath of type I and type III collagen (Messenger et al. 1991). This is continuous with the papilla, the protrusion of the dermis into the base of each follicle. A basement membrane containing type IV collagen, laminin, HSPG, nidogen, laminin 1 and proteoglycans, (Messenger et al. 1991; Holbrook et al. 1993), separates the epithelial cells of the follicle from the papilla and the connective tissue sheath. 
The epithelial components of the follicle are the outer root sheath, the inner root sheath, and the cells lying around the dermal papilla which are called the matrix. Proliferation is confined to cells in the matrix and in the outer root sheath below the insertion of the arrector pili muscle (Chapman 1986). The central matrix cells give rise to the hair cortex which produces the hair fibre. The cells in the peripheral matrix form the outermost layer of the hair, the cuticle. The inner root sheath cells, that line the follicle next to the hair cuticle resemble cornified keratinocytes (Kealy and Philpot 1994).

The upper hair follicle is marked by the insertion of the arrector pili muscle and the sebaceous gland. Outer root sheath cells above the sebaceous gland differentiate in the same manner as basal cells in the inter follicular epidermis (Coulombe et al. 1989). In some species, such as the rat, the region adjacent to the insertion of the arrector pili muscle is marked by a clear bulge (Kobayashi et al. 1993). The bulge is not seen in humans but the cells of this region and the outer root sheath cells just below it may be identified as they express keratin 19 (Stasiak et al. 1989; Lane et al. 1991).

Hair follicles are continually cycling, going through three phases of growth. In anagen active hair growth occurs. In catagen, mitotic activity in the matrix ceases. The matrix cells detach from the basal lamina (Parakkal 1969) and are degraded by macrophages. In the telogen phase the follicle becomes dormant. A new anagen phase then begins; the old hair is expelled and a new one is formed (Chapman 1986; Kealy and Philpot 1994).

The skin contains two types of sweat glands. Eccrine glands are tubular structures that secrete sweat onto the surface of the skin via a sweat duct. They are found in all body sites. Apocrine glands are found on the axillae, groin and scalp, and discharge via a duct into the upper hair follicle (Odland 1991). 


\section{Cell-Celland Cell-ECM AdHesion IN THE EPIDERMIS}

\section{Cell Matrix adhesion}

Basal keratinocytes adhere to basement membrane proteins via two sorts of adhesive junction, hemidesmosomes and focal contacts.

\section{Hemidesmosomes}

In hemidesmosomes adhesion to basement membrane is mediated by the $\alpha_{6} \beta_{4}$ integrin (Carter et al. 1990; Stepp et al. 1990) (see below). The other protein that may have a role in adhesion to the basement membrane is the $180 \mathrm{kd}$ bullous pemphigoid antigen 2 (BPAG2) a transmembrane protein with an extracellular domain that contains a collagen like domain (Figure 1.2). Auto antibodies against BPAG2 produce the disease bullous pemphigoid in which blisters arise from the separation of basal cells from that basement membrane (Stanley 1995).

Hemidesmosomes are not formed in standard keratinocyte cultures. Structures called stable anchoring contacts on the basal surface of cultured keratinocytes which may represent precursors of hemidesmosomes, since they contain both $\alpha_{6} \beta_{4}$ integrin and $230 \mathrm{kD}$ hemidesmosomal plaque protein, bullous pemphigoid antigen (Carter, Kaur et al. 1990; Marchisio et al. 1990).

\section{Focal Contacts}

Focal contacts were originally identified as sites at which the basal surface of cultured cells is closely apposed to the culture substrate (Turner and Burridge 1991). They can be visualised by interference reflection microscopy. Adhesion to ECM at focal contacts is mediated by integrins, which are linked to actin microfilament bundles by intermediate proteins such as talin, vinculin and $\alpha$ actinin (Figure 1.6, Otey et al. 1990; Johnson and Craig 1995). The types of integrins found in focal contacts vary according to the nature of the ECM on the culture substrate (Carter et al. 1990). As well as having a mechanical role components of focal contacts are also involved in integrin mediated signalling (see Chapter 7). Integrins, talin, vinculin and focal adhesion kinase are localised at the basal surface of basal keratinocytes in the epidermis, suggesting that focal contacts may also exist in vivo (Kaiser et al. 1993; Kubler and Watt 1993; Gates et al. 1994). 


\section{The integrins}

The integrins are a family of cell surface glycoproteins involved in cell-ECM and cell-cell adhesion. They are very widely expressed in many cell types and are found in vertebrates and in invertebrates. Integrins mediate numerous cell-ECM interactions in development and differentiation, including the induction of gene expression by ECM proteins (Hynes 1992; Adams and Watt 1993). Several pathological processes such as leukocyte migration, platelet aggregation and invasion and metastasis in cancer also involve integrins (Hynes 1992).

\section{Integrin Structure}

All integrins are heterodimers comprising an $\alpha$ and a $\beta$ subunit. Many different $\alpha$ and $\beta$ subunits have been identified and over 20 different pairs of subunits have been found in vivo (Hynes 1992). $\alpha$ subunits range from $120-180 \mathrm{kD}$ and $\beta$ subunits from $90-110 \mathrm{kD}$ in size. Each subunit has a short transmembrane domain and a cytoplasmic tail that is usually less than $\mathbf{5 0}$ amino acids in length except in the case of $\beta_{4}$ where it is over 1000 amino acids. The extracellular domains of the $\alpha$ and $\beta$ subunits interact non covalently to form the receptor (Figure 1.7).

The $\alpha$ subunits can be sub classified into subtypes on the basis of the structure of the extracellular region (Figure 1.8). Some such as $\alpha_{2}$ contain a conserved region known as the I domain which has a role in ligand binding (Haas and Plow 1994). Other $\alpha$ subunits that lack the I domain are post translationally cleaved into a light chain and a heavy chain which are linked by a disulphide bond (Hynes 1992).

Most $\beta$ subunits form heterodimers with several different $\alpha$ subunits. The $\alpha$ subunits confer ligand specificity. For example in keratinocytes $\beta_{1}$ binds fibronectin when partnering $\alpha_{5}$ and collagen and laminin when partnering $\alpha_{2}$ (Hynes 1992). Ligand specificity is also dependent on the cell type in which an integrin is expressed: $\alpha_{2} \beta_{1}$ for example binds only to collagen in MRC5 fibroblasts, but will bind collagen and laminin in a bladder carcinoma cell line (Hemler et al. 1990; Kirchhofer et al. 1990).

Integrins can be functionally active or inactive (Adams and Watt 1990). There is evidence that both subunits contribute to the regulation of integrin activity. Monoclonal antibodies against the $\beta_{1}$ subunit can either inhibit or activate ligand 
binding (Akiyama et al. 1989; Kovach et al. 1992). Function modulating antibodies all bind to epitopes within a region of the $\beta_{1}$ subunit that lies between the 2 putative ligand binding domains (Figure 1.7) (Shih et al. 1993). It is thought that these antibodies induce conformational changes in the binding site that affect its ability to bind ligand. This hypothesis is supported by the existence of antibodies that only recognise the $\beta_{1}$ subunit in its active state (Kovach et al. 1995), presumably by binding to an epitope only exposed in the active conformation. Ligand binding affinity is also modulated by extracellular cations (Kirchhofer et al. 1990; Kirchhofer et al. 1991). Each $\alpha$ subunit contains at least 3 repeats of a cation binding motif, which appear to be directly involved in ligand binding interactions (D'Souza et al. 1994; Haas and Plow 1994).

The cytoplasmic tails of both subunits also play a role in regulating integrin function. The $\alpha$ subunit tail is essential for maintaining integrins in their active conformation and is required for the upregulation of integrin function by signals from within the cell, so called "inside out" signalling (Kassner and Hemler 1993; Kawaguchi and Hemler 1993). The $\beta_{1}$ subunit tail is required both for adhesive function and for the migration of $\beta_{1}$ integrins into focal contacts. These functions are mediated by separate regions of the cytoplasmic tail (Reszka et al. 1992; Hemler et al. 1994). There are several potential phosphorylation sites on the $\beta_{1}$ tail. Correlative evidence suggests that changes in phosphorylation are associated with changes in the activity of $\beta_{1}$ integrins (Hemler et al. 1994).

\section{Keratinocyte Integrins}

Several integrins are expressed in keratinocytes. $\alpha_{2} \beta_{1}, \alpha_{3} \beta_{1}$ and $\alpha_{6} \beta_{4}$ are abundantly expressed in vivo and in vitro. Their ligands have been identified using affinity chromatography and function blocking monoclonal antibodies in vitro adhesion assays. In cultured keratinocytes the ligands for $\alpha_{2} \beta_{1}$ are type 1 collagen, type IV collagen and laminin 1. $\alpha_{3} \beta_{1}$ binds laminin 1 and laminin 5 (Carter et al. 1990a,b; Adams and Watt 1991; Carter, et al. 1991). $\alpha_{6} \beta_{4}$ is the integrin found in the hemidesmosome complex, discussed above (Stepp et al. 1990). The ligands recognised by $\alpha_{6} \beta_{4}$ in cultured cells are laminin 1 and laminin 5 (Lee et al. 1992; Sonnenberg et al. 1993). The large cytoplasmic tail of the $\beta_{4}$ subunit may be involved with interactions with plaque proteins (Legan et al. 1992). Keratinocytes isolated directly from epidermis adhere readily to collagen types I and IV and laminins 1 and 5 (Toda and Grinnell 1987; Rousselle and Aumailley 1994), presumably via the same integrins as cultured keratinocytes. It has been shown that 
freshly isolated keratinocytes bind to laminin 5 via the $\alpha_{3} \beta_{1}$ integrin (Rousselle and Aumailley 1994).

$\alpha_{5} \beta_{1}$ and $\alpha_{v} \beta_{5}$ are also readily detectable in cultured keratinocytes where they function as fibronectin and vitronectin receptors respectively (Adams and Watt 1990; Adams and Watt 1991). In vivo the expression of both integrins is very low (Hertle et al. 1991; Hertle et al. 1992), or undetectable (Peltonen et al. 1989; Pellegrini et al. 1992). This parallels the availability of ligand - fibronectin is only found at very low level in the basement membrane and vitronectin is undetectable (Reily and Nash 1988). Freshly isolated keratinocytes do not adhere to fibronectin; but after 1 week in culture cells adhere rapidly (Toda and Grinnell 1987). This has led to the proposal that exposure to dermal fibronectin is one of the signals that activates keratinocyte migration and proliferation in wound healing (Grinnell 1992).

The other integrins expressed in keratinocytes are $\alpha_{1} \beta_{1}$, which is only just detectable, and $\alpha_{8} \beta_{1}$ and $\alpha_{9} \beta_{1}$. The ligands recognised by these integrins in keratinocytes are unknown (Belkin et al. 1990; Buck et al. 1990; Bossy et al. 1991; Hertle, Adams et al. 1991; Palmer et al. 1993).

Keratinocytes express the splice variant $\left(\beta_{1 B}\right)$ form of the $\beta_{1}$ integrin subunit. In $\beta_{1 \mathrm{~B}}$ the 21 carboxy terminal amino acids of $\beta_{1 \mathrm{~A}}$ are replaced by a unique 12 amino acid domain (Balzac et al. 1993). The function of $\beta_{1 B}$ in keratinocytes is unknown. The $\alpha_{6 \mathrm{~B}}$ splice variant of $\alpha_{6}$ is not found in the epidermis which only expresses the classical form. The form of $\beta_{4}$ found in the skin contains a 53 amino acid insert not found in $\beta_{4}$ from retinal pigment cells or carcinoma cells (Suzuki and Naitoh 1990; Tamura et al. 1990)

Integrin expression is almost entirely confined to cells in the basal layer, both in normal adult epidermis and in cultured keratinocytes (De Strooper et al. 1988; Peltonen et al. 1989; De Luca et al. 1990; Adams and Watt 1991). Expression of the $\alpha_{6} \beta_{4}$ integrin is mostly confined to the basal surface of the basal cells. Some $\alpha_{2} \beta_{1}$ and $\alpha_{3} \beta_{1}$ is found on the basal cell surface, but the level of expression of these integrins appears to be higher at the lateral and apical borders of basal cells in vivo and in vitro (De Strooper, Saison et al. 1988; Peltonen et al. 1989; De Luca et al. 1990; Hertle, et al. 1991). This has led to the proposal that integrins are involved in cell-cell adhesion (discussed below). 


\section{Integrins and keratinocyte differentiation}

Some of the earliest events in the differentiation of basal cells involve changes in function of integrins. Freshly isolated or cultured basal cells adhere to ECM whereas suprabasal cells do not (Stanley et al. 1980; Toda and Grinnell 1987; Adams and Watt 1991). As cells leave the basal layer they lose expression of integrin ECM receptors (Larjava et al. 1990; Adams and Watt 1991; Hertle et al. 1991; Hertle et al. 1992). The process of receptor loss has been studied in detail and involves transcriptional and post transcriptional mechanisms (Hotchin and Watt 1992).

Depriving basal cells of contact with ECM by placing them in suspension causes them to differentiate. By 24 hours in suspension basal keratinocytes express the terminal differentiation marker involucrin; by three days in suspension many cells have synthesised a cornified envelope (Green 1977; Rice and Green 1978; Rice and Green 1979; Simon and Green 1984). Basal cells can be rescued from differentiation by the addition of fibronectin to the suspension culture (Adams and Watt 1989). Antibodies against the fibronectin receptor, the $\alpha_{5} \beta_{1}$ integrin also block suspension induced differentiation (Adams and Watt 1989). The time at which fibronectin is added is crucial; if cells have been in suspension for five hours or more it has no effect (Adams and Watt 1990), despite the fact that surface expression of the $\alpha_{5} \beta_{1}$ integrin is unchanged. Thus deprivation of ECM sends a signal to basal cells that results in their differentiation. Differentiation results in a loss in the ligand binding ability of the $\alpha_{5} \beta_{1}$ integrin (Adams and Watt 1990). This is an example of "inside out signalling" in which intracellular events alter integrin function (Hynes 1992). The loss of integrin function is a marker of commitment to terminal differentiation in keratinocytes (Adams and Watt 1990; Hotchin et al. 1993).

\section{Cell-Cell adhesion}

\section{Cadherins}

Keratinocytes express several members of the cadherin superfamily of cell-cell adhesion molecules. E cadherin is expressed by keratinocytes in all cell layers while $P$ cadherin expression is confined to the basal layer (Nose and Takeichi 1986; Shimoyama et al. 1989). E and $P$ cadherins are found in adherens junctions, which link the actin cytoskeleton of adjoining cells. Desmosomes, which link the keratin 
filament network of adjoining cells, contain the desmosomal cadherins, desmoglein and desmocollin (Legan et al. 1992).

Cell-cell adhesion is mediated through homotypic interaction of cadherin extracellular domains (Geiger and Ayalon 1992; Overduin et al., 1995), and is dependent on the presence of extracellular calcium. The cytoplasmic tail of the cadherin molecule interacts with cytoplasmic proteins called catenins. Three catenins have been identified: $\alpha$ catenin; $\beta$ catenin and plakoglobin (Cowin et al. 1986; Cowin 1994). There is evidence that catenins regulate cadherin function (Hinck et al. 1994a).

One role of cadherins in keratinocyte differentiation has been identified by studies of keratinocyte stratification in vitro. Keratinocytes were cultured at low $(0.1 \mathrm{mM})$ calcium ion concentrations. Under these conditions differentiated keratinocytes, identified by their expression of the terminal differentiation marker involucrin, adhere to ECM via integrins (Watt and Green 1982; Hodivala and Watt 1994). When the calcium ion concentration is raised to $1.8 \mathrm{mM}$, the involucrin positive cells stratify, cease integrin transcription and lose surface expression of integrins within 6 hours (Hodivala and Watt 1994). Treating the cells with antibodies to P and $E$ cadherin prevents the loss of integrin mRNA and protein from differentiating cells (Hodivala and Watt 1994). Microinjection of antibodies to $\beta$ catenin and plakoglobin also blocks integrin loss whereas antibodies to $\alpha$ catenin do not (K Hodivala, V Braga and F M Watt, unpublished observations). This suggests that cadherins, acti via catenins to regulate the loss of integrin expression that occurs on stratification.

\section{CD44, the peanut lectin binding protein}

The peanut lectin (PNA), which recognises the disaccharide DGal $\beta$ (1-3)DgalNAc (Lotan et al. 1975) binds more strongly to suprabasal than basal keratinocytes in vitro and in vivo, making it a useful differentiation marker (Watt 1993b). The core protein whose glycosaminoglycan side chains are bound by PNA is CD44 (Hudson and Watt In press). CD44 is present in both basal and suprabasal layers. The increase in PNA binding in suprabasal cells is due to the loss of terminal sialic acid from CD44 glycosaminoglycan side chains, which occurs as cells leave the basal layer (Morrison et al. 1988; Keeble and Watt 1990). The function of CD44 is unclear. One of its splice variants is able to confer metastatic ability to tumour lines (Arch et al. 1992). In keratinocytes it may be involved in hyluronate dependent 
cell-cell adhesion (Milstone et al. 1994). It may also have a role in signalling (Isacke 1994). The functional significance of the change in sialiation with differentiation is unknown.

\section{Integrins in cell-cell adhesion}

The expression of $\alpha_{2} \beta_{1}$ and $\alpha_{3} \beta_{1}$ integrins at the lateral surface basal keratinocytes has led to the proposal of that these integrins might function in cell-cell adhesion (Marchisio et al. 1990). Function blocking anti $\beta_{1}$, anti $\alpha_{2}$ and anti $\alpha_{3}$ integrin subunit antibodies are known to disrupt cell-cell adhesion in keratinocytes cultured in low (0.1mM) concentrations of extracellular calcium ions (Larjava et al. 1990). However these antibodies have no effect on cell-cell adhesion at more physiological extracellular calcium ion concentrations (1.8mM) (Tenchini et al. 1993). As the function of integrins and cadherins is affected by the extracellular calcium ion concentration, it is difficult to interpret the result of experiments performed at $0.1 \mathrm{mM}$ calcium ion concentration.

Other workers have proposed that the $\alpha_{2} \beta_{1}$ and $\alpha_{3} \beta_{1}$ integrins in keratinocytes mediate cell-cell adhesion by binding to each other. However their results do not demonstrate a direct interaction between these integrins in vivo (Symington et al. 1993). However there is recent evidence the $\alpha_{4} \beta_{1}$ integrin on lymphocytes can bind directly to $E$ cadherin on epithelial cells. It remains to be seen if the $\beta_{1}$ integrins of keratinocytes can bind directly to cadherins.

\section{CULTURE OF EPIDERMAL KeRATINOCYTES}

There are several methods of keratinocyte culture, each suited to the study of a different aspect of keratinocyte behaviour (Watt 1993a). The method used most extensively for the study of epidermal stem cells is that developed by Rheinwald and Green, which permits culture of keratinocytes at clonal densities. In this technique a single cell suspension of keratinocytes harvested from neonatal foreskin epidermis is seeded onto a feeder layer of irradiated 3T3 embryo mouse fibroblasts in an appropriate medium with $10 \%$ foetal calf serum (Rheinwald and Green 1975; Rheinwald 1989). The growth medium is supplemented with insulin, hydrocortisone, and cholera toxin which stimulate cell proliferation (Rheinwald and Green 1975; Green 1978), and epidermal growth factor, which delays senescence of cultures and promotes migration of the cells at the edge of colonies (Rheinwald and Green 1977; Barrandon and Green 1987a). Cells grown under these conditions can 
be repeatedly subcultured, though cultures senesce after about 8 rounds of passage (Rheinwald 1989).

The keratinocyte colonies eventually fuse to form a confluent stratified sheet 6-8 cells in thickness. Desmosomes and adherens junctions are formed (Watt et al. 1984; Magee et al. 1987; O'Keefe et al. 1987). The suprabasal layers exhibit an accelerated program of differentiation. Cells in the first suprabasal layer are negative for integrins but express involucrin and show increased binding to PNA (Watt and Green 1982; Morrison et al. 1988; Adams and Watt 1991). The uppermost cell layer consists of squames complete with a cornified envelope (Green 1977; Rice and Green 1979), though these cells still contain nuclei (Green 1977). Many of the ultrastructural features of keratinocytes in vivo such as desmosomes and keratin filaments are preserved, though hemidesmosomes are not formed in basal cells (Holbrook and Hennings 1983). When confluent Rheinwald and Green cultures are transplanted as skin grafts onto burns patients (Compton et al. 1989) or onto nude mice (Barrandon et al. 1988), they rapidly assume an appearance almost identical to normal human epidermis.

\section{EPIDERMAL TURNOVER}

\section{Cell loss from the epidermis}

There are two possible routes of cell loss from the epidermis, cell shedding from the cornified layer and apoptotic cell death. The rate of shedding decreases with age and increases with frictional stress, but in normal adult hair bearing body skin the rate of loss is such that the all the cells outermost cornified cell layer are shed in about 24 hours (Baker and Kligman 1967; Jansen et al. 1974; Roberts and Marks 1980). Apoptosis was originally defined as a process distinct from cell shedding, in which a cell within a tissue detaches from its neighbours, involutes, undergoes degradation of the nucleus and other organelles and then disintegrates to be engulfed by a tissue macrophage (Kerr et al. 1972). Thus defined there is no evidence for apoptosis in normal epidermis, though it does occur in disease, for example in sunburn (Ziegler et al. 1994).

In cells undergoing apoptosis, the nucleus is degraded by endogenous nucleases, producing a characteristic "ladder" pattern of DNA fragments that can be seen on gel electrophoresis (Wyllie 1980). Terminally differentiating keratinocytes degrade their nuclei as they enter the cornified layer, resulting in a ladder pattern of DNA 
fragments in granular layer cells (Karasek 1988; McCall and Cohen 1991; Polakowska et al. 1994). This observation has led to the proposal that apoptosis is part of normal keratinocyte differentiation (Polakowska et al. 1994). This requires broadening the original definition of apoptosis, to any process in which a cell degrades its nucleus by endogenous nucleases.

\section{Replacement of lost cells}

The cells that are lost from the cornified layer are replaced by cell division. When human subjects were injected with a pulse of tritiated thymidine to determine the location of $S$ phase cells, the labelled cells were confined to the basal and first suprabasal cell layers (Epstein and Maibach 1965; Penneys et al. 1970). 70\% of labelled cells lie in the basal layer (Penneys et al. 1970). Using this technique, estimates of the proportion of $S$ phase cells in adult hair bearing skin range from 15\% (Dover 1994). Other markers of cell proliferation, such as proliferating cell nuclear antigen expression, Ki67 antigen expression and AgNor staining give very similar results (Pierard-Franchimont and Pierard 1989; Jakic-Razumovic et al. 1992; Hall et al. 1993; Barker et al. 1993). These results are consistent with the observation that each squame occupies the same area as 25 basal cells (Holbrook 1994). In the steady state, assuming cell shedding is the only means of cell loss from the epidermis, $4 \%$ of cells in the basal cell layers should divide every day.

In culture proliferation is also confined to basal cells (Dover and Potten 1983; Choi and Fuchs 1990). In preconfluent Rheinwald and Green cultures pulsed with tritiated thymidine most positive cells are found at the edges of colonies and $30 \%$ of the cells are labelled (Dover and Potten 1983). As the culture approaches confluence the proportion of labelled cells falls to $5 \%$, close to what is seen in vivo (Dover and Potten 1983; Watt et al. 1989).

The proportion of actively cycling epidermal cells is subject to considerable diurnal variation. The mean mitotic rate in neonatal foreskins is twice as high in specimens removed at 10 pm compared with those collected at 9 am (Cooper and Franklin 1938). In a study of mitotic rate in shoulder epidermis in young adults a similar pattern was found - in the same individual proliferation was 2-6 fold higher at 9 am than at midnight (Scheving 1959). 
It has long been known that proliferating cells are not evenly distributed along the basal layers of the epidermis but occur clustered together in patches. In his study of mitosis in neonatal foreskins Thuringer noted that he could count as many as 10-14 mitotic figures per $\times 400$ field at the centre of a "growth wave", and that in adjacent fields the number of mitoses per field tapered off to zero (Thuringer 1928). A similar phenomenon is described by Scheving (Scheving 1959).

\section{STEM CELLS AND THE MAINTENANCE OF TISSUE TURNOVER}

\section{Stem cell theory}

The epidermis is able to replace the outermost cornified layer at least once a day for up to a century. This requires regenerating the basal layer at least once per month. Two theories have been put forward to explain the maintenance of the epidermis. The first was that basal cells arose from the differentiation of more primitive cells in the dermis or in the hair follicle (Scheving 1959). There was no evidence of cells migrating into the epidermis, and the ability of grafted human sole keratinocytes to maintain their pattern of keratin expression when grafted onto abdominal skin (Compton 1993) is powerful evidence against this model.

The other explanation is that the basal layer contains stem cells. The term stem cell was originally coined to describe the germ cells which both self renew and generate progeny that differentiate to become somatic cells (Figure 1.9A) (Wilson 1896; Wilson 1927). The proliferative cells that maintained tissue integrity were not described as stem cells in the early literature. However, writing in 1901, Adami stated that in normal tissues such as the epidermis "the actively-functioning and fully-developed cell, as such, does not undergo mitosis or show evidences of multiplication". Lying within the epidermis were " proliferous or 'mother cells', cells which themselves throughout life do not attain full differentiation but which give off daughter cells and the daughter cells it is which develop into the fully differentiated functional cells". The proliferation of mother cells is regulated by signals from "the surrounding daughter. cells. Ewing endorses these ideas: "in most organs certain groups of cells are set aside for growth, and from these are derived the more specialised functionating cells... Examples are...the cells at the bases of intestinal villi and the basal cells of the epidermis" (Ewing 1907).

Later Berenblum applied the term stem cell to the mother cells in the basal epidermis, as their behaviour resembled that of germ cells (Figure 1.9C) 
(Berenblum 1954). In the steady state each stem cell division will generate one stem cell and one differentiating cell. The number of basal cells remains constant because the differentiating cells move out of the basal layer. Subsequently cells in responsible for maintaining various tissues have been described as stem cells (Lajtha 1979).

\section{Lessons from Haemopoiesis}

The first direct evidence for the existence of stem cells came not from the epidermis but from the haemopoietic system. In 1956 Ford et al showed that cells in donated marrow were able to reconstitute the entire haempoietic system in lethally irradiated recipient mice (Ford et al. 1956). Till and McCulloch then showed that single bone marrow cells, termed spleen colony forming units (CFU-S ), founded colonies of haemopoietic cells in the spleens of recipient mice. The colonies contained over $10^{6}$ cells and contained cells that had the morphology of blood cell precursors of different lineages (Till and McCulloch 1961; Becker et al. 1963; Curry and Trentin 1967). Serial transplantation of cells from the spleen colonies showed that CFU-S had a high capacity to self renew.

Further in vitro studies showed that haemopoietic stem cells (HSC) do not give rise to differentiated cells directly, but via populations of committed progenitor cells (CPC), which are restricted to a single lineage and have a limited capacity to self renew. For example, there are three committed progenitors of erythrocytes which found three sizes of erythroid colonies in vitro. Burst forming cells (BFU-E) give rise to the large colonies containing over 10,000 terminally differentiated red cell precursors. Erythroid colony forming units, CFU-E, are derived from BFU-E and form smaller colonies. CFU-E differentiate into erythroblasts, the third type of CPC which found microscopic colonies (Metcalf 1984; Castoldi and Beutler 1988). In each lineage a similar hierarchy of CPC's is seen. The current model of stem cells and CPC's in the bone marrow is shown in Figures 1.10 and 1.11.

The existence of the hierarchy of CPC explains how HSC, which only make up $0.1 \%$ of cells in the bone marrow can sustain the enormous rate of cell turnover of the haemopoietic system. In humans $2 \times 10^{11}$ erythrocytes and $7 \times 10^{10}$ neutrophils have to be produced each day, merely to maintain the steady state (Ogawa 1993). The HSC maintain a small population of early CPC, but each early CPC generates a large number of differentiated progeny. In the erythrocyte lineage, for example, there are about 6 BFU-E to each HSC. A single BFU-E cell can generate 9400 
erythrocytes per day via CFU-E and proerythroblasts (Figures 1.9, 1.10) (Metcalf 1984).

How do HSC function in normal animals as opposed to those recovering from bone marrow transplantation? Since stem cells only have to maintain a small number of early CPC in each lineage Lajtha argued that stem cells must divide relatively rarely in the steady state. The majority stem cells would be withdrawn from the cell cycle in a resting state, called Go (Lajtha 1979). Studies in which high dose tritiated thymidine is used to ablate cycling cells in normal mice, support this hypothesis. Most HSC are unaffected by the pulse of thymidine (Becker et al. 1965) whereas the majority of CPC's died. This suggests most CPCs are proliferating in the steady state, while most HSC are not (Gregory and Eaves 1977; Brandt et al. 1988 ).

Thus the early studies on haemopoiesis suggested that tissue specific stem cells were highly proliferative with an extensive capacity to self renew. HSC generated post mitotic terminally differentiated blood cells via committed progenitors. In the steady state the stem cells were unlikely to be cycling compared with the CPC.

\section{Models of Epidermal stem cells}

Several authors attempted to apply these principles from haemopoiesis to stem cells in the epidermis. They relied on two basic assumptions. The first was that the basal layer contains sub populations of cells analogous to the populations of stem cells and committed precursors in the haemopoietic system (Potten 1974; Potten 1976; Lajtha 1979; Potten 1981). Stem cells were proposed to have a high capacity to proliferate and would self renew. The committed progenitors, which were termed "transit amplifying cells" (TA) by Potten, would execute several rounds of division and then differentiate to form post mitotic cells. The second assumption was that the basal cell subpopulations would have the same cell kinetic properties as blood cell precursors. Thus in the steady state epidermal stem cells would be expected to be slowly cycling while the TA cells would be actively dividing.

There is some experimental evidence that is claimed to be consistent with both assumptions. Potten examined the published radiobiological data on the epidermis, to try to determine the number of clonogenic cells in the basal layer. He estimated that only 3-7\% of basal cells in the mouse are clonogenic (Potten and Hendry 1973; Potten 1975), and inferred that the basal epidermis does indeed contain 
subpopulations of cells which differ in their proliferative potential. However the method used by Potten has been questioned, as the margin of error in his calculations is likely to be over 10 fold (see Figure 1.12) (Wright and Alison 1984). Other authors state that the calculating of the number of clonogenic cells present in epidermis prior to irradiation from cell survival curves is impossible (Withers 1967; Archambeau 1987).

There do appear to be some basal cells that divide less frequently than others in the steady state in vivo. When mice are given a series of tritiated thymidine injections almost $100 \%$ of the cells in the epidermis are labelled (Bickenbach 1981). Three months later some cells in the epidermis still retained label. These cells were termed label retaining cells (LRC). As cell division would be expected to dilute out the thymidine, it was argued that LRC were slowly cycling and therefore might be stem cells (Potten 1981). LRC have also been found in the bulge of the hair follicle (Cotsarelis et al. 1990).

The first model built from these assumptions was the epidermal proliferative unit (Potten 1974). Mackenzie had observed that the squames in the cornified layer of the dorsal mouse epidermis are arranged in ordered columns, and unlike human epidermis the alignment of cells in the basal layer corresponded to the shape of the column (Figure 1.13) (Mackenzie 1970). Fewer of the basal cells lying under the centre of each cornified cell were in mitosis than the cells under the edge of the cornified cell. Some of the central cells were later found to be LRC (Potten and Morris 1988). From these observations Potten suggested that the central cells were stem cells, which maintained the cornified cells in the column above (Potten 1974; Potten 1975; Potten 1976; Potten 1981; Potten and Morris 1988). This theory is not consistent with observations in chimeric mice, where epidermal cells migrate across the boundaries of the supposed EPU (Schmidt et al. 1987), and cannot be applied to human epidermis where there is no alignment between the columns of squames and particular basal cells (Mackenzie et al. 1981).

A similar approach was applied to human epidermis by Lavker and Sun. They noted that there are two populations of basal keratinocytes which differ in their ultrastructure. In some cells, numerous small processes project from the basal surface of the cell into the basement membrane. In other cells the basal surface of the cell is parallel to the basement membrane (Odland 1958). These cells are termed serrated and non serrated respectively (Lavker and Sun 1982). In human 
abdominal skin and in monkey palm, serrated cells have been seen overlying the dermal papillae, whereas non serrated cells lie in the rete ridges (Hibbs and Clark 1959; Lavker and Sun 1982). Lavker and Sun argued that stem cells ought to be well protected, and therefore be situated deep in the epidermis, while terminally differentiating cells should lie close to the skin surface. The non serrated cells were deepest in the epidermis and had "primitive" ultrastructural features, so might be stem cells (Lavker and Sun 1983). Further, only $0.5 \%$ of the basal cells at the deepest part of the rete ridges in the monkey palm were found to be in $S$ phase, as assayed by tritiated thymidine uptake, compared with $3.5 \%$ of cells on the sides of the rete ridge. It was not stated whether this difference was statistically significant, but these results were interpreted as supporting the idea that stem cells lay in the deep rete ridges in the palm (Lavker and Sun 1983). Equating the non serrated cells with stem cells it was inferred that stem cells in trunk skin resided in the rete ridges (Cotsarelis et al. 1989). However, others have concluded that, in view of the lack of firm evidence, "we are really ignorant" about the organisation of stem cells the epidermis, particularly in humans (Wright and Alison 1984).

\section{Stem cells in vitro}

The long term survival of cultured grafts suggests that keratinocyte stem cells persist in RG cultures. When the colonies formed by keratinocytes were examined after 2 weeks in culture they differed markedly in size (Rheinwald and Green 1975; Barrandon and Green 1985; Barrandon and Green 1987b). This demonstrated that not all basal cells have the same proliferative potential.

Barrandon investigated the colonies in more detail by culturing single cells and then sub culturing the cells in the resulting clones. Three sorts of colonies were identified based on their appearance and their behaviour when sub cloned. Holoclones (HC) contain 2-5 X $10^{4}$ cells, both basal cells, and suprabasal cells, which express the terminal differentiation marker involucrin. Paraclones contain up to 1000 cells, all of which became involucrin positive after 12 days in culture. Paraclone colonies are highly irregular in shape. Meroclones have intermediate characteristics between holoclones and paraclones, containing several thousand cells but having an irregular shape. When cells from each type of colony are passaged after 6 days in culture, the colonies founded by cells in holoclones are mostly holoclones with a few meroclones. Meroclones found meroclone and paraclone colonies. Paraclones only found a few colonies, all of which were paraclones. Thus the basal cell population contains a hierarchy of colony forming 
cells analogous to the hierarchy of haematopoietic progenitors but confined to the keratinocyte lineage. This is in accordance the theories of Potten. Cells that found holoclones have a high proliferative potential and can undergo extensive self renewal. The founders of paraclones are only able to divide a maximum number of 10-15 times, even if sub cloned, after which all of their progeny undergo terminal differentiation. Once a cell has become a meroclone, it cannot revert to being a holoclone. Paraclones are never able to produce meroclones or holoclones, unless they are transformed with a viral oncogene (discussed below) (Barrandon and Green 1987b).

When the proportions of colony types formed by second passage keratinocytes isolated from neonatal skin were analysed $28 \%$ were holoclones, $49 \%$ meroclones and $23 \%$ paraclones. In a 78 year old there were no holoclones, $10 \%$ meroclones and $90 \%$ paraclones. The loss of holoclones from elderly skin may reflect senescence of holoclones, such as occurs in vitro, or damage and loss of holoclones caused by agents such as ultraviolet radiation (Barrandon and Green 1987b).

\section{Stem cells in Hair Follicles}

The evidence for the existence of a population of cells that can generate large numbers of epidermal keratinocytes in the hair follicle is much more robust. In partial thickness burns that islands of regenerating epidermis are seen growing outwards from the remnants of hair follicles (Bereiter-Hahn 1986). LRC are found in the bulge region (Cotsarelis et al. 1990). The bulge is clearly defined in rodents and by using micro dissection techniques it was possible to demonstrate that in the rat almost all the cells that founded keratinocyte colonies in vitro were located in the bulge (Kobayashi et al. 1993). The bulge is not visible in human hair follicles but is thought to correspond to the area immediately below the insertion of the arrector pili muscle. Two groups have used micro dissection to shown that the area corresponding to the bulge and the region just deep to it contain numerous cells that found keratinocyte colonies in vitro (Yang et al. 1993; Rochat et al. 1994). Whether these cells normally support hair production and are induced to differentiate into keratinocytes by in vitro culture or whether they are dedicated epidermal stem cells is not known. 


\section{THENEED FOR EPIDERMAL STEM CELL MARKERS}

The study of epidermal stem cells has been greatly restricted because of the lack of markers that would enable the isolation of viable stem cells from the epidermis. The ability to purify viable stem cells would be a step towards answering several questions of major biological importance, which are set out below.

\section{Stem cell fate determination}

An area of lively debate in the study of stem cells concerns the cell fate decisions of stem cells, whether they self renew or differentiate. This may be a random, stochastic process, may be regulated by the microenvironment, or may be predetermined. Most of the studies of this question are from the haemopoietic field where HSC can be isolated for study using combinations of molecular markers (Spangrude et al. 1988; Charbord 1994).

Evidence for the stochastic view comes from the finding that the observed distribution of the number of HSC and their differentiated progeny in vivo or in vitro can be precisely reproduced by a computer model which assumes cell differentiation occurs at random with a probability of 0.4 (Till et al. 1964; Nakahata et al. 1982). Typical cell fate trees produced in the model are shown in Figure 1.11. The ability HSC to divide asymmetrically to produce daughter cells with different fates, assumed by the model, has been demonstrated in vitro. For example, in one case the 2 daughters of a single stem cell generated a $10^{4}$ cell colony containing only erythroid cells and a 500 cell neutrophil/macrophage lineage colony (Suda et al. 1984).

Observations of keratinocytes cultured in vitro with time lapse video microscopy provide some evidence that keratinocyte differentiation may be stochastic. The cell fate trees of cultured keratinocytes have a striking resemblance to the behaviour of cells in a stochastic model (see Figure 1.14) (Till et al. 1964; Dover and Potten 1988). The interpretation of these results is difficult. Cell fate trees have been determined for three cells, and these are incomplete. Furthermore it is not clear if the keratinocytes being observed were stem cells or transit cells. However these observations do suggest that one daughter of a keratinocyte can continue to 
proliferate while the other undergoes terminal differentiation (Dover and Potten 1988). This contrasts with cells such as oligodendrocyte precursors where the decision to terminally differentiate appears to be regulated by an intrinsic cellular clock. The clock counts the number of divisions a cell has undergone; once a certain number of divsions has occurred, the clock signals to the cell, instructing it to terminally differentiate. If the daughter cells of a single oligodendrocyte precursor are separated and cultured apart from each other they undergo the same number of rounds of cell division and then terminally differentiate (Temple and Raff 1986).

An alternative model is that the fate of a stem cell is determined by its environment. There are a multiplicity of growth factors that control the survival, proliferation and differentiation of haemopoietic stem cells and there progeny (Metcalf 1992; Metcalf 1993; D'Andrea 1994). Stromal cell interactions are also essential for haemopoiesis (Flanagan et al. 1991; Morisson-Graham and Takahashi 1993; Funk et al., 1994; Miyake et al. 1991; Yanai et al. 1994; Williams et al. 1991). Even so HSC lines enabled to survive in the absence of growth factors by introduction of the BCL2 proto oncogene were still able to differentiate (Fairburn and Cowling 1993), suggesting growth factors are not an essential requirement for differentiation.

There are also numerous growth factors and cytokines that either stimulate or inhibit keratinocyte proliferation in vitro and in vivo (Rheinwald and Green 1977; Barrandon and Green 1987 ; Dominey et al. 1993; Guo et al. 1993; Strange et al. 1993; Shipley et al. 1986; Sellheyer et al. 1993; Parkinson et al. 1993). The extent to which such factors modulate epidermal stem cell fate decisions is likely to remain unclear until stem cells can be isolated.

\section{Psoriasis}

Psoriasis is a benign disorder of keratinocyte proliferation. Patients develop red scaly plaques on extensor surfaces, which appear and disappear spontaneously. Histologically the disease is characterised by hyperproliferation and thickening of the epidermis and the presence of a lymphocytic infiltrate (Lever and Schaumberg -Lever 1983). The labelling index of keratinocytes in psoriatic plaques is two to three fold that of cells in normal epidermis (Dover 1994). Keratinocytes hyperproliferate in response to stimuli from the plaque infiltrating lymphocytes (Nicholas et al. 1991; Prinz et al. 1991; Nickoloff et al. 1994; Prinz et al. 1994). It is not known if the cells that respond to cytokines are stem cells or transit 
amplifying cells. Purification of stem cells would offer the prospect of an improved understanding of the pathogenesis of psoriasis.

\title{
Stem cells and Cancer
}

A connection between stem cells and cancer was proposed by Adami as long ago as 1901 (Adami, 1901). He postulated that cancer arose from the "mother cells" in the basal layer of the epidermis. This hypothesis is attractive as an explanation of 2 step carcinogenesis in mice (Berenblum 1954; Hennings et al. 1993). Only an initiated stem cell could persist in the epidermis to be transformed by the later application of a promoter (Cairns 1975; Pierce and Speers 1988). However there is experimental evidence that keratinocyte stem cells are not the only targets for carcinogens. Introduction of a viral oncogene into paraclone cells, which normally differentiate within a few round of cell division, is able to restore their growth potential (Barrandon et al. 1989). If stem and transit cells could be separated the target cells for carcinogenic agents and the nature of growth regulation of stem and transit cells could be more clearly defined.

\section{Keratinocyte gene therapy}

Keratinocytes have been shown to be a potential vehicle for the gene therapy of clotting factor IX deficiency (Haemophila B) and $\alpha 1$ antitrypsin deficiency in a nude mouse model (Gerrard et al. 1993; Setoguchi et al. 1994). Circulating factor IX and $\alpha 1$ antitrypsin are detected initially, but expression is short lived. One factor that might improve the possibility of achieving long term expression of genes in keratinocyte grafts is the availability of purified populations of epidermal stem cells (Greenhalgh et al. 1994).

\begin{abstract}
AIMS
The aim of this study was to isolate and characterise human epidermal stem cells in vitro and in vivo. In view of the relationship between keratinocyte differentiation and the loss of integrin function in basal keratinocytes it seemed possible that the least differentiated keratinocytes, the stem cells, might be the most adhesive. I therefore set out to investigate if there was a relationship between the integrin mediated adhesiveness of basal keratinocytes and their proliferative potential.
\end{abstract}


It was essential to define criteria that could be used to identify an epidermal stem cell. From the evidence presented above several characteristics can be suggested. An epidermal stem cell should have a high proliferative potential, and thus be clonogenic in vitro. It should generate differentiated progeny and self renew, and be able to reconstitute an epidermis in vivo. If epidermal stem cells gave rise to differentiated keratinocytes via a population of committed progenitors, they would be expected to be slowly cycling in the steady state in vivo. Finally any putative stem cell marker might be expected to identify cells in the bulge region of the hair follicle as well as stem cells in the interfollicular epidermis. I began the search for stem cells in vitro using keratinocyte cultures (see Chapter 3) 
FIGURE 1.1: The structure of the epidermis

The cell layers and changes in keratinocyte morphology are shown. Note that basal cells express keratins 5 and 14 (in green) whereas keratinocytes in other layers express 1 and 10 (in pink). In hair bearing skin the cells in the stratum corneum are arranged in columns (Mackenzie et al. 1981), and are 6-7 times the diameter of basal cells. Figure adapted from (Fuchs 1990). 


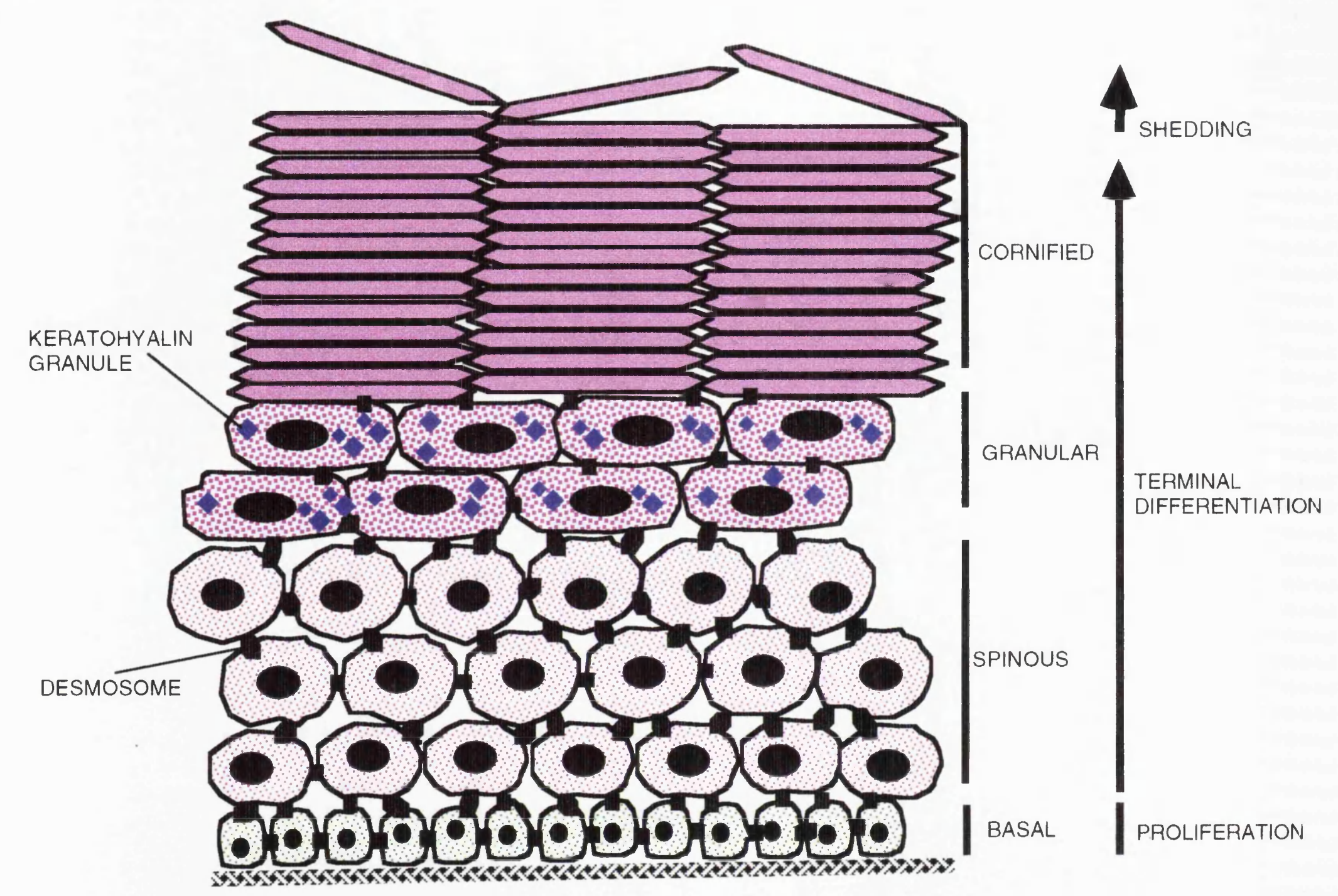


FIGURE 1.2: The structure of the hemidesmosome

Bundles of keratin intermediate filaments insert into an electron dense plaque, which contains the $230 \mathrm{kD}$ bullous pemphigoid antigen (BP230). The cytoplasmic tail of the $\beta_{4}$ subunit of the $\alpha_{6} \beta_{4}$ integrin may bind to proteins in the plaque, while its extracellular portion binds to laminin in the basement membrane. Another possible cell adhesion molecule in the hemidesmosome is bullous pemphigoid antigen 2, (BPAG2).

The anchoring filaments are composed of laminin 5, anchoring fibrils from type VII collagen and the anchoring plaques from collagen types IV and VII.

Figure adapted from Legan et al. (1992). 
CYTOPLASM

MEMBRANE

BASEMENT MEMBRANE

DERMIS

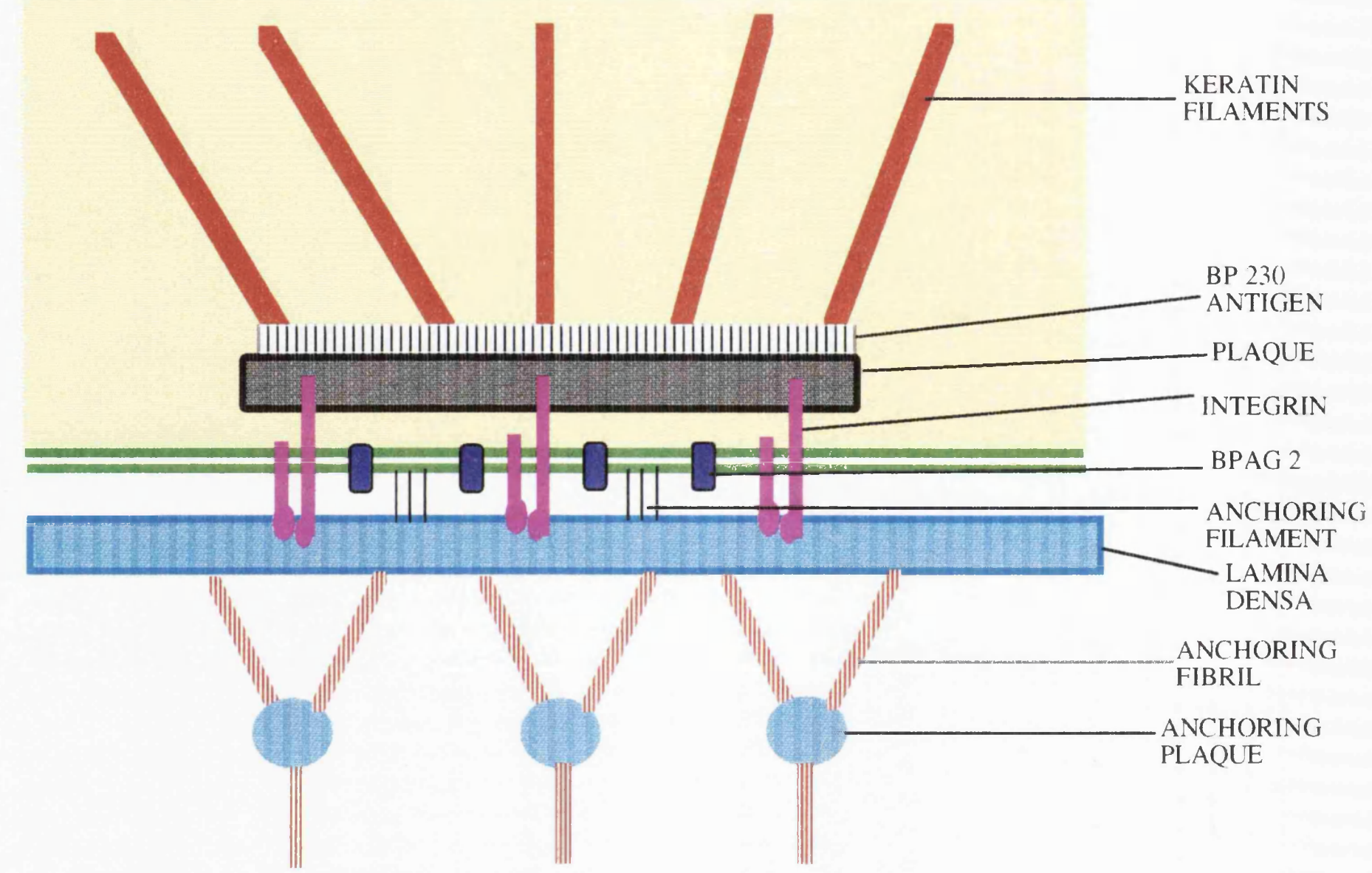


FIGURE 1.3: The arrangement of dermal papillae and rete ridges in the palm and sole.

The epidermis is in pink and dermis in blue. Figure after Chacko and Vaidya (1968).

In the palm and sole the dermal papillae are in the form of longitudinal ridges. 


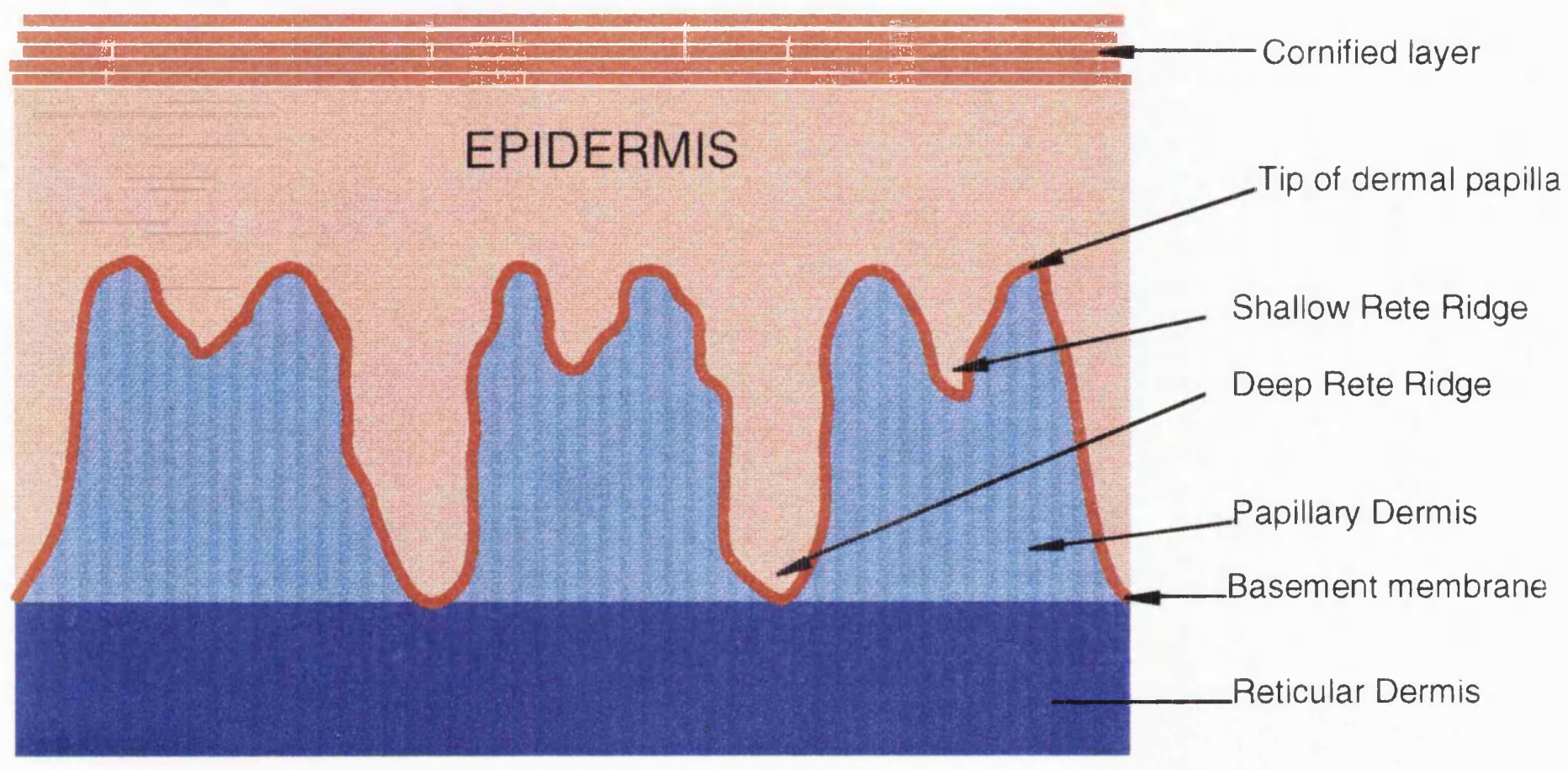

DERMIS 
FIGURE 1.4: Dermal papillae in thin skin.

True papillae are present, unlike the palm and sole. Figure from Scothorne and Hunter (1981) Reproduced by permission of Blackwell Scientific Publications. 


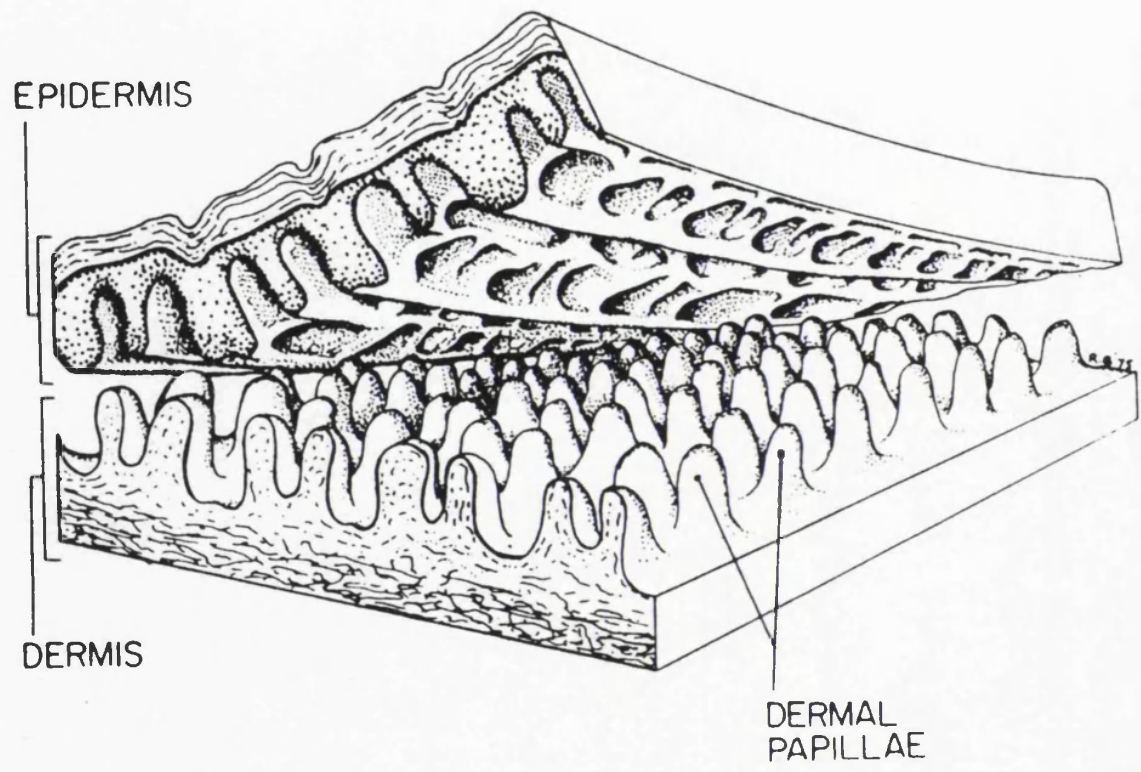


FIGURE 1.5: The structure of the hair follicle

Figure adapted from Fuchs and Byrne (1994). 


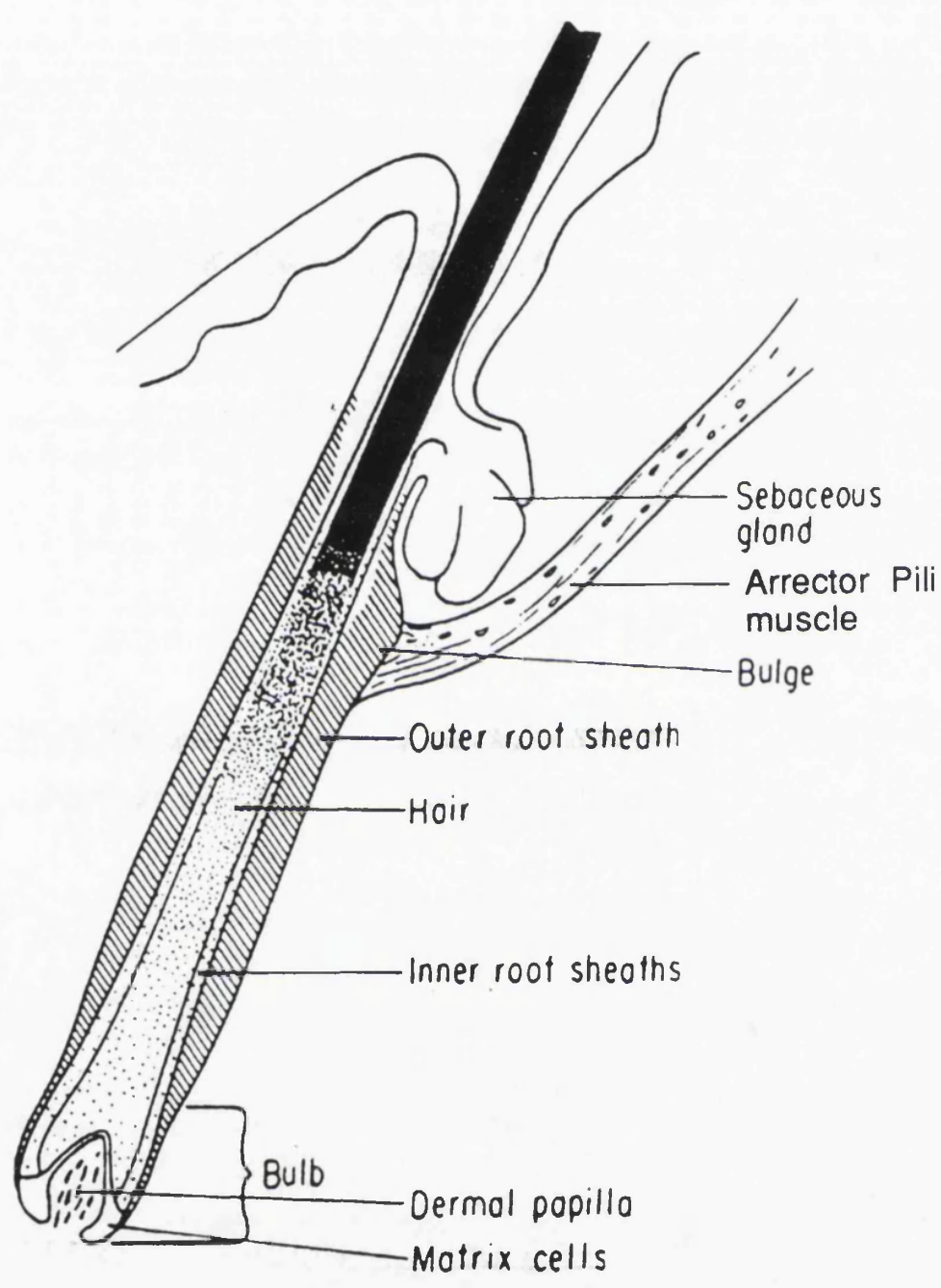


FIGURE 1.6: The structure of focal contacts

Some of the proteins involved in focal contacts are shown. Figure adapted from Luna and Hitt (1992); Johnson and Craig (1995); Schlaepfer et al (1994); and Schaller and Parsons (1994). 


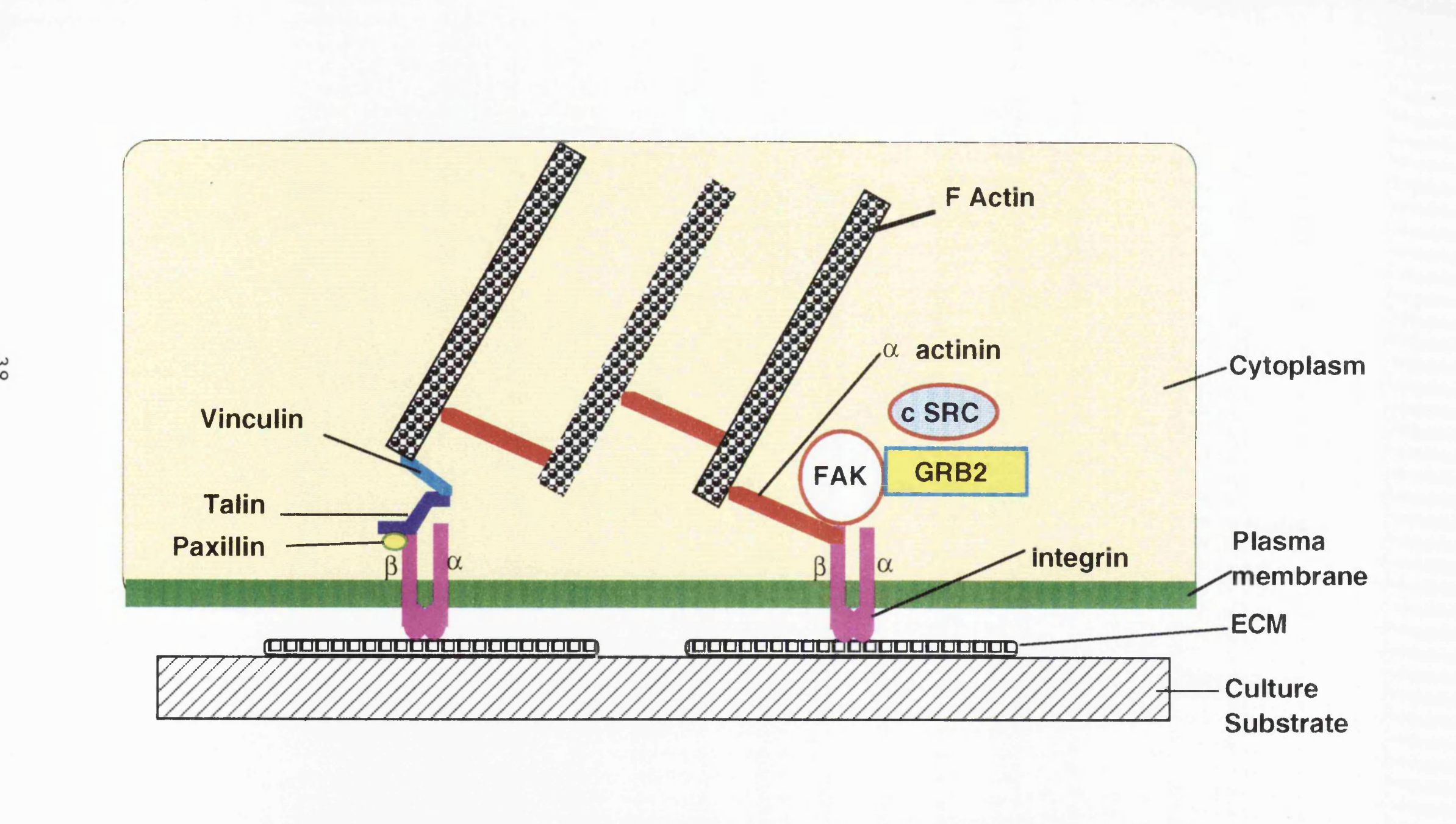




\section{FIGURE: 1.7 Integrin Structure}

A The arrangement of $\alpha$ and $\beta$ integrin subunits in the cell membrane, based on their electron microscopic appearance. Figure adapted from Hynes, (Hynes 1992).

B The nature of the integrin ligand binding site. Both subunits contribute to ligand binding. The $\alpha$ subunit binding domain contains cation binding sites. The $\beta$ domain has 2 areas thought to interact directly with ligand (ligand binding domains, LBD) separated by a region containing epitopes of integrin function regulating antibodies (in red). Numbers are the number of amino acid residues from the $\mathrm{N}$ terminus of the $\beta$ subunit. Figure adapted from Haas and Plow (1994). 
A

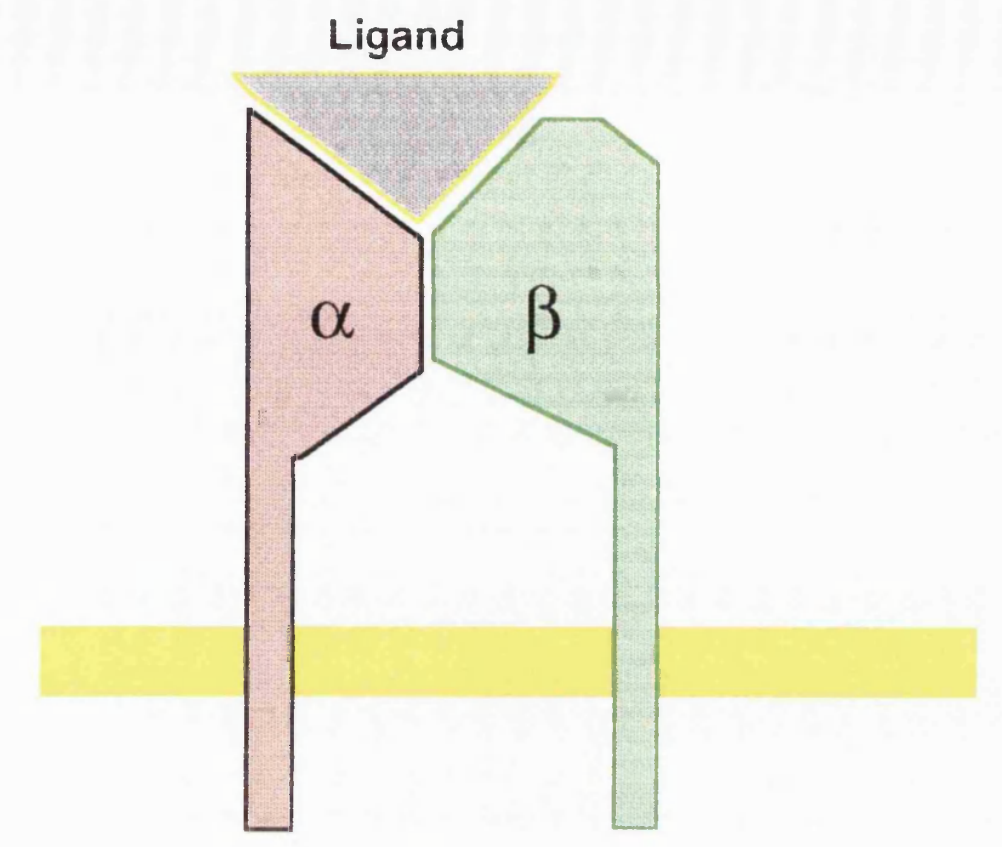

B

Cytoplasm

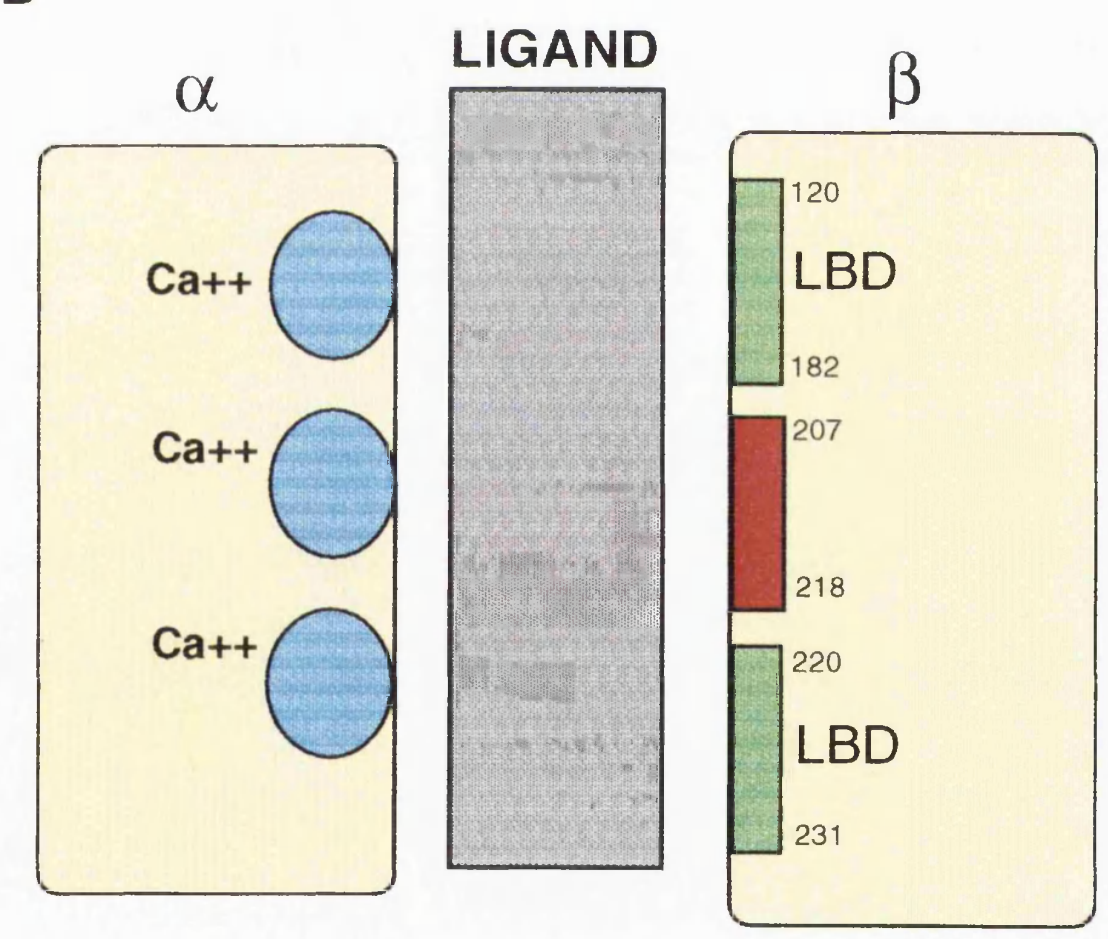


FIGURE 1.8: Structural relationships between integrin $\alpha$ subunits The cleaved and I domain sub families are shown. The tree is branched according to the degree of sequence identity. The $\beta$ subunits which partner the different $\alpha$ subunits are shown on the right of the figure. The integrins expressed in keratinocytes are shown in red. Figure adapted from Hynes (1992) and Palmer et al. (1993). 


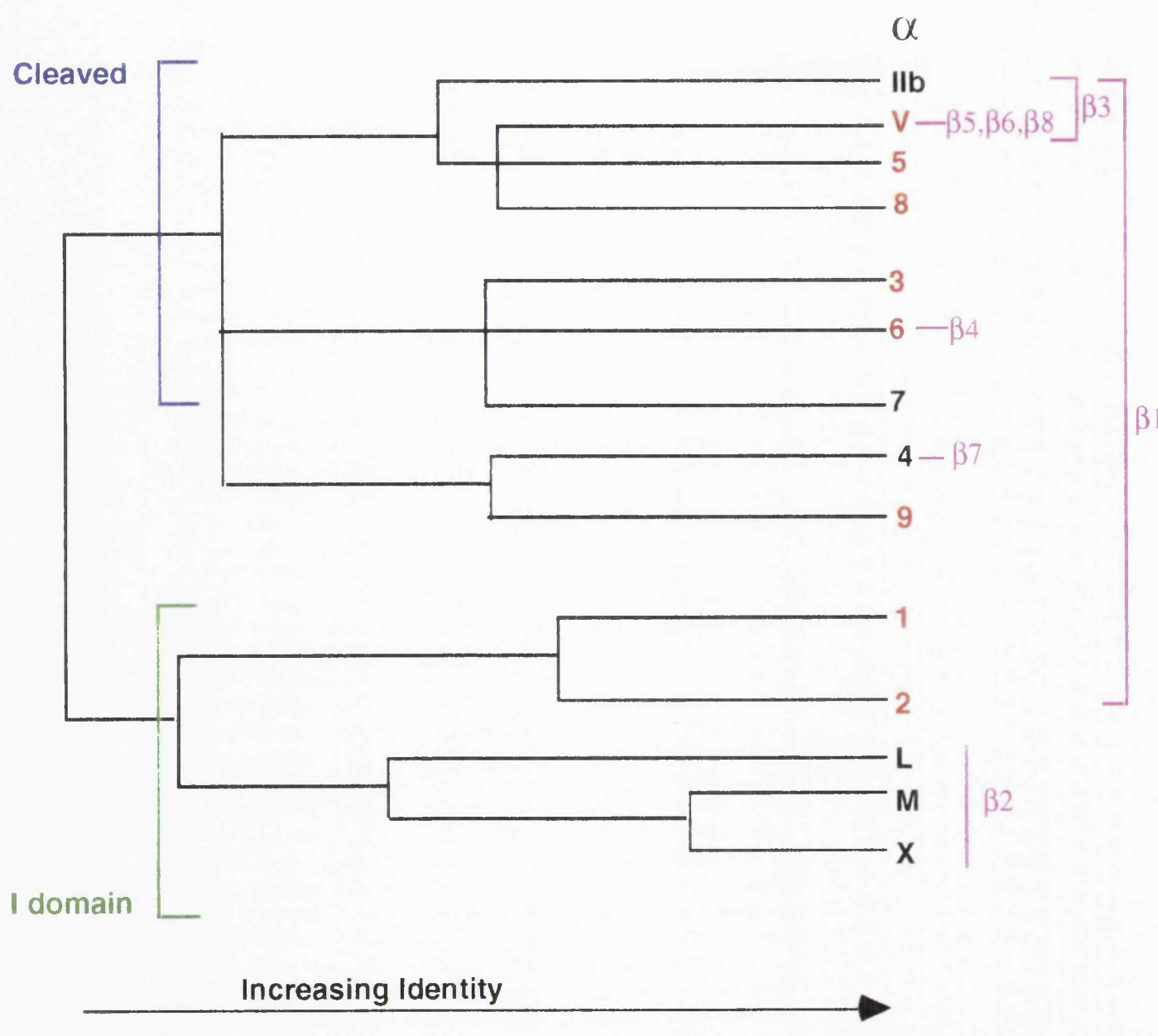


FIGURE 1.9: The development of models of tissue specific stem cells

A Stem cells as cells that generate both somatic and germ cells in the developing Ascaris (Wilson 1927).

B The existence of a hierarchy of lineage committed precursor cells with progressively diminishing proliferative potential generating differentiated cells in spermatogenesis (Wilson 1896). The existence of similar populations of progenitors was demonstrated in the haemopoietic system over 60 years later.

C The epidermal stem cell model of Berenblum. Berenblum proposed the existence of epidermal subpopulations as follows:

(k): keratin shed from surface

$\mathbf{k}$ : adherent keratin

d: dying cells (in stratum spinsosum and lucidum) $\mathrm{m}_{2}, \mathrm{~m}_{3:}$ maturing cells ( in stratum spinosum) $\mathrm{M}_{1:}$ maturing cell still possessing capacity to divide S: Stem cell (in stratum germinatum), not yet begun maturing Boxed in groups: cells still capable of division Solid arrow: progression by division

Interrupted arrow: progression by moving to surface Figure adapted from Berenblum (1954). 
A

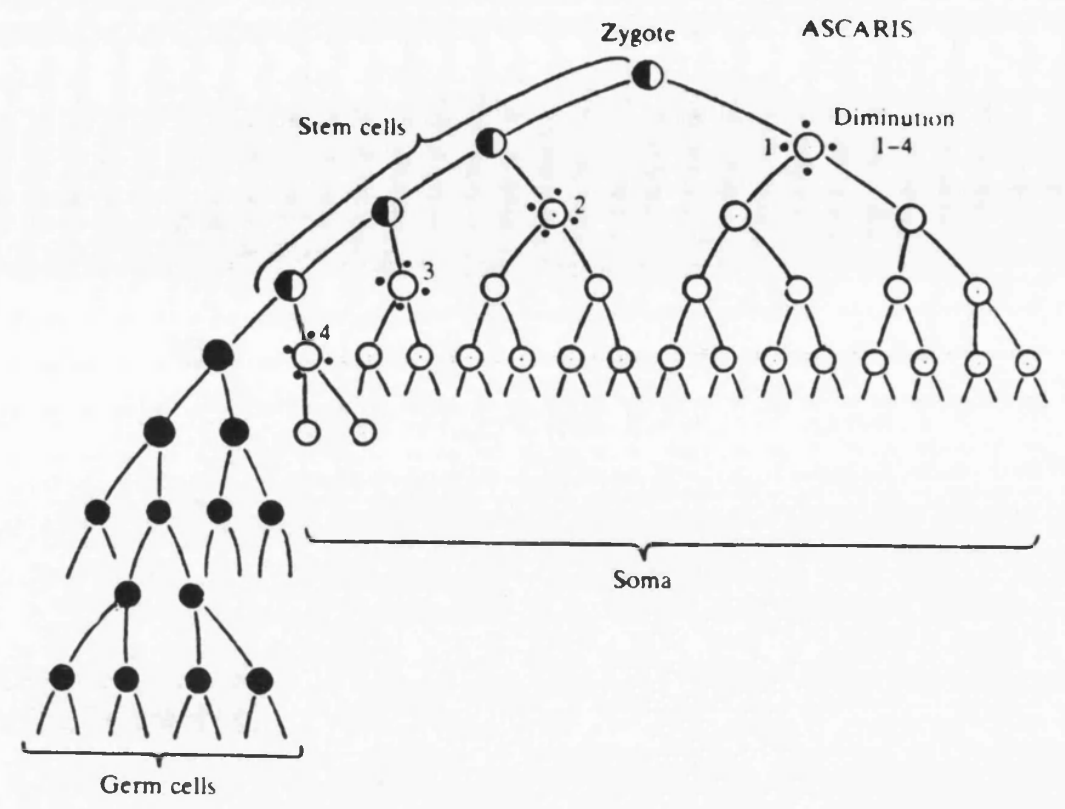

B

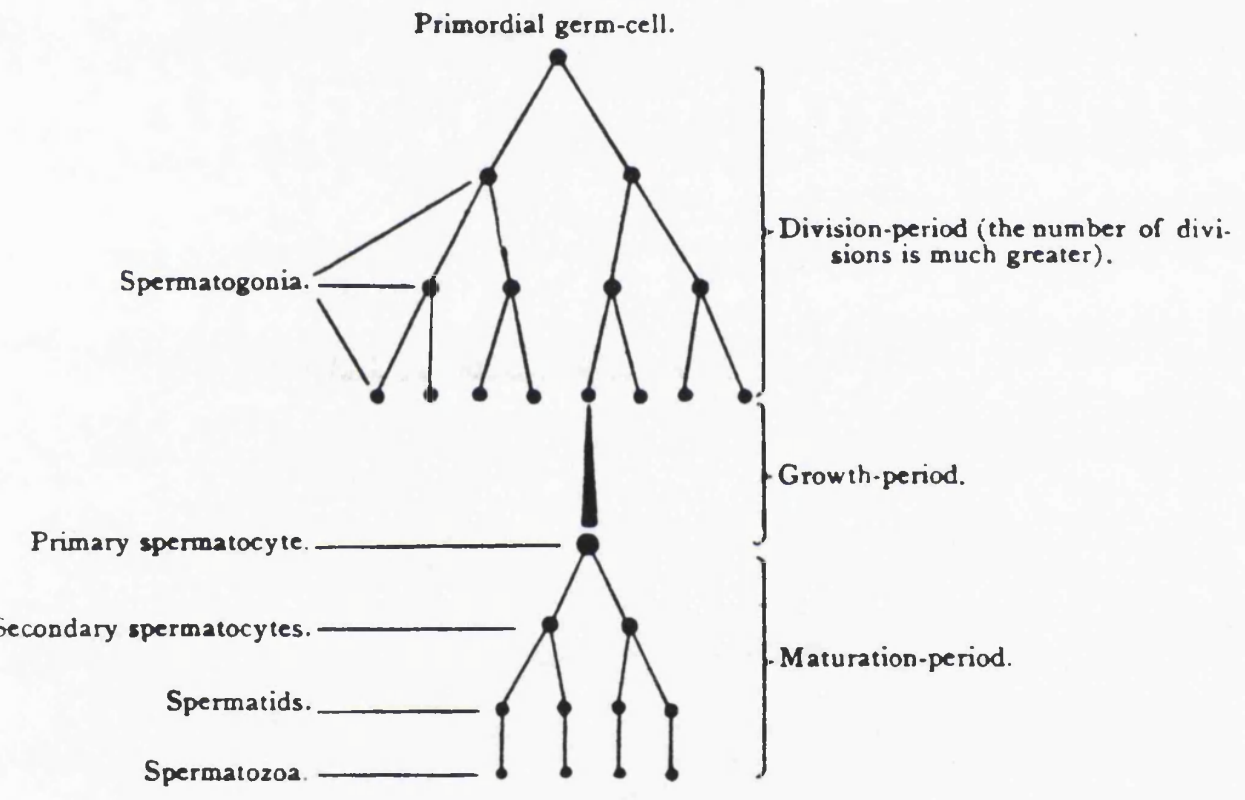

C

(n)


FIGURE 1.10: A Current model of haempoietic progenitor cells

Adapted from Chervenick et al. (1988) and Ogawa (1993).

CFU-S - spleen colony forming unit

BFU-E - burst forming unit, erythroid

CFU-E - colony forming unit erythroid

CFU-NM - colony forming unit neutrophil/monocytic

CFU-EOS - colony forming unit eosinophillic

CFU-BASO - colony forming unit basophillic

CFU-MEG - colony forming unit megakaryocytic

PLSC - primitive lymphoid stem cell 


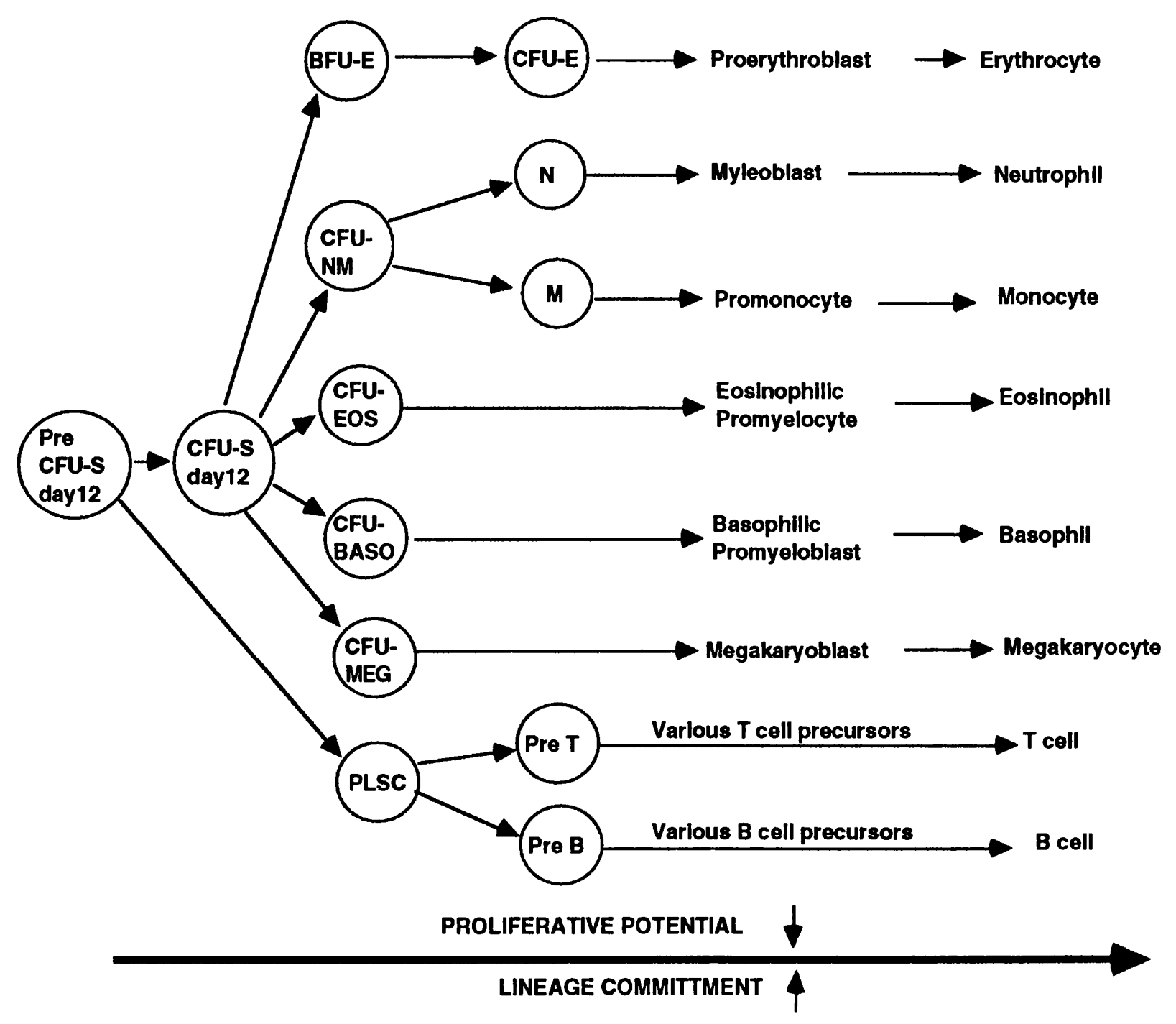


FIGURE 1.11: Behaviour of committed erythroid progenitor cells Figure adapted from Castoldi and Beutler (1988). E1 to E5 are different stages of proerythroblast. After the E5 stage the cells differentiate into reticulocytes and leave the bone marrow as anucleate erythrocytes. 


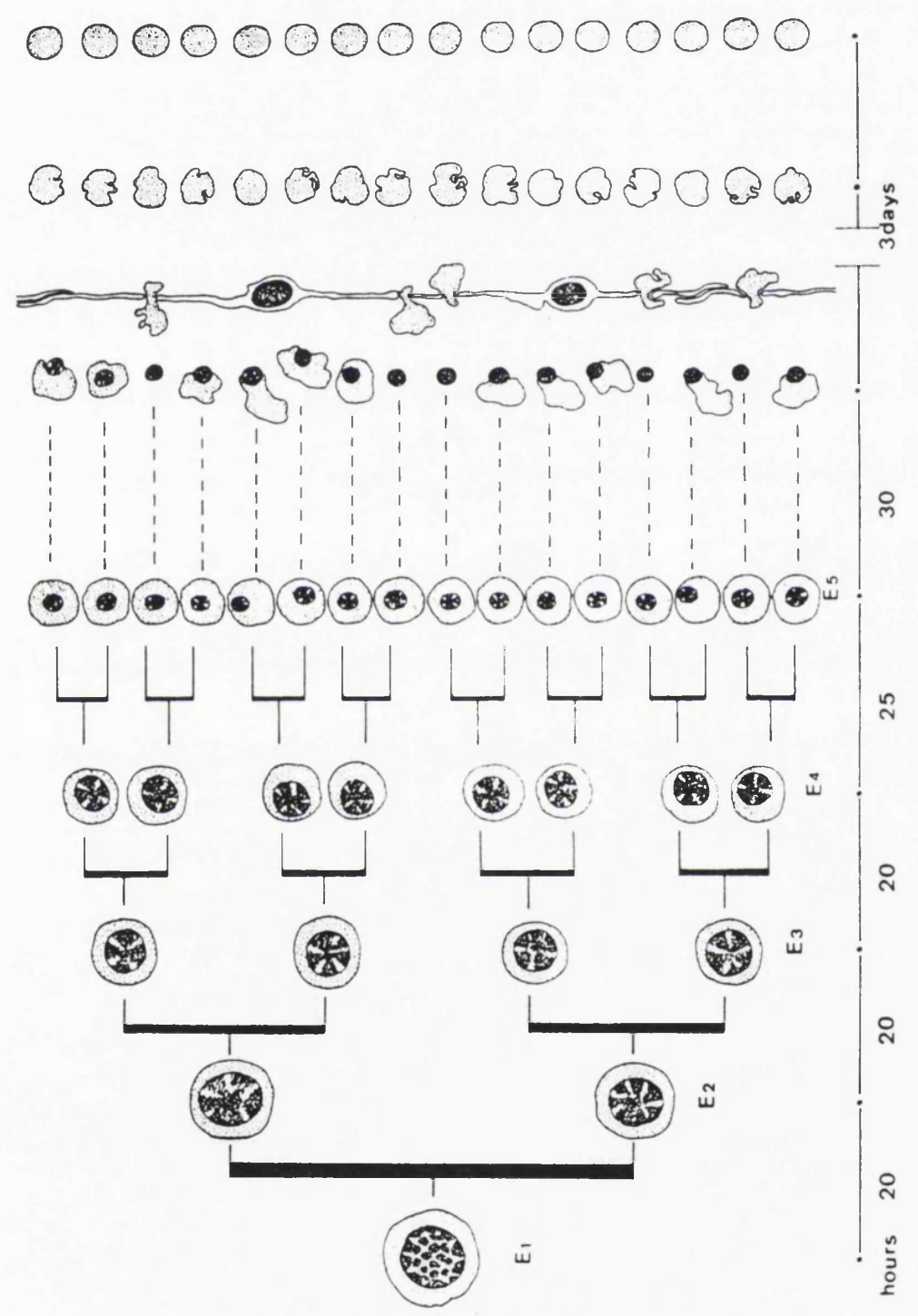


FIGURE 1.12: Use of radiobiological data to estimate the number of epidermal stem cells

Potten and Hendry (1973) extrapolated from known clonogenic cell survival data, shown in black solid line (for a single fraction of radiation) and dotted black line (for the same total dose, given as 2 fractions, 24 hours apart). They assumed that the intercepts of these 2 lines with the $y$ axis are at A and $B$ as shown and that these are a constant multiple of the number of stem cells prior to irradiation. The survival curve is thought to be non linear at small doses (shown in red), due to the cell's ability to recover from low doses of radiation. From the difference between the $y$ axis intercepts at points A and B, Potten and Hendry estimated the number of clonogenic cells in mouse skin prior to irradiation. There are problems with this approach:

1) It assumes that the linear quadratic model of cell survival extends over the whole range of cell survival values, as well as that measured.

2) The assumption that the split dose curve is parallel to the single fraction curve is not known to be true at low doses.

3) A small error in estimating the slope of either line will produce a very large error in the intercept with the $y$ axis as the $y$ axis units are logarithmic.

Other authors maintain it is not possible to estimate the number of cells at zero dose with this approach (see text). Figure adapted from Potten and Hendry (1973). 


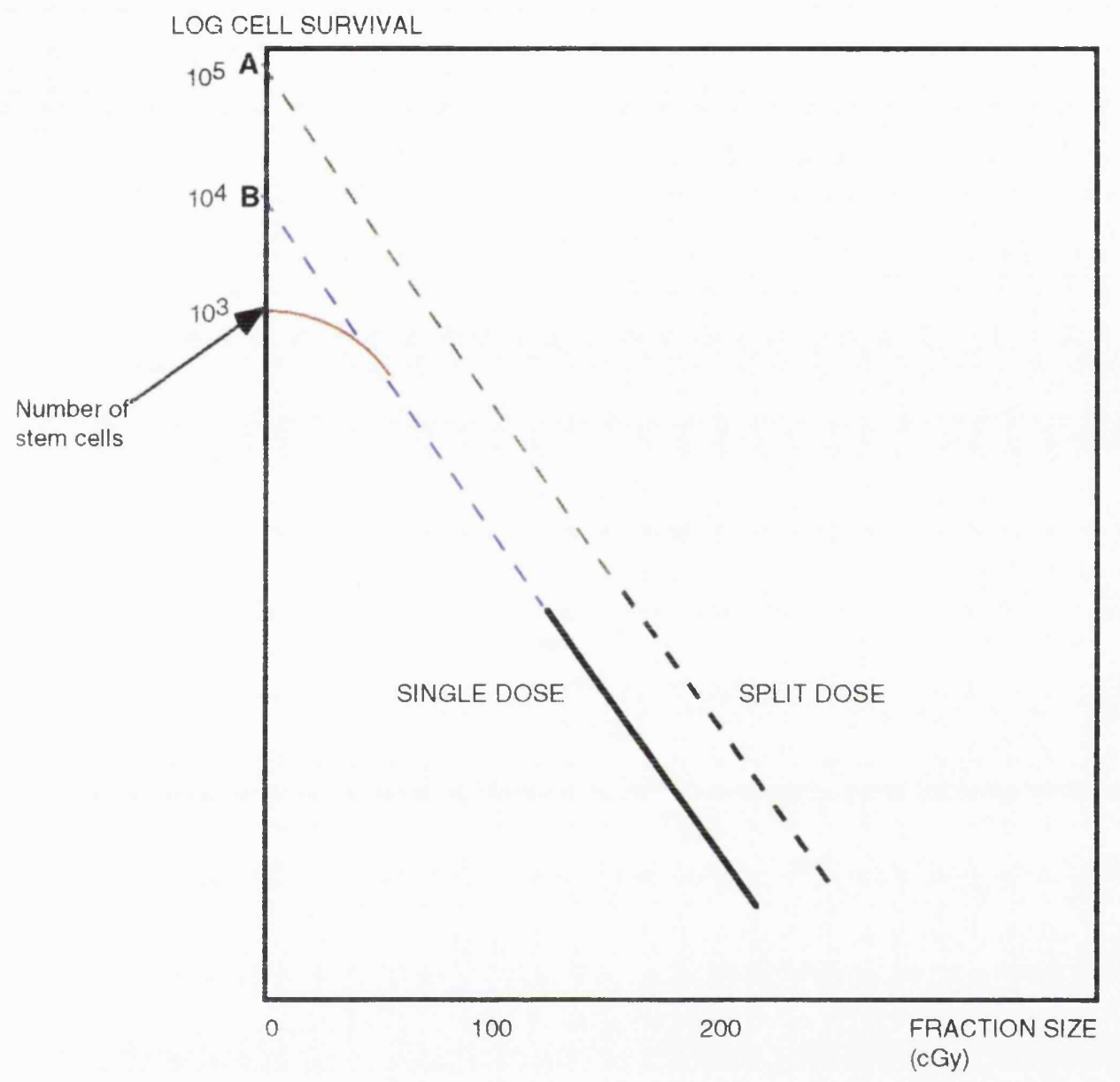


FIGURE 1.13: The epidermal proliferative unit

Mackenzie observed that in the dorsal epidermis of the mouse cells in the basal layer were clearly aligned with the columns of squames in the cornified cell layer (Mackenzie, 1970). This is apparent both when the epidermis is viewed enface (A) and in cross section (B). He found that the peripheral basal cells (shown in green) were more likely to be in mitosis than the central cell (shown in red). Potten later suggested that the central cells were stem cells which maintained the overlying column of squames. In this model the committed progenitors, called transit amplifying cells by Potten, are the peripheral basal cells. Figure adapted from Potten and Morris (1988). 
ш
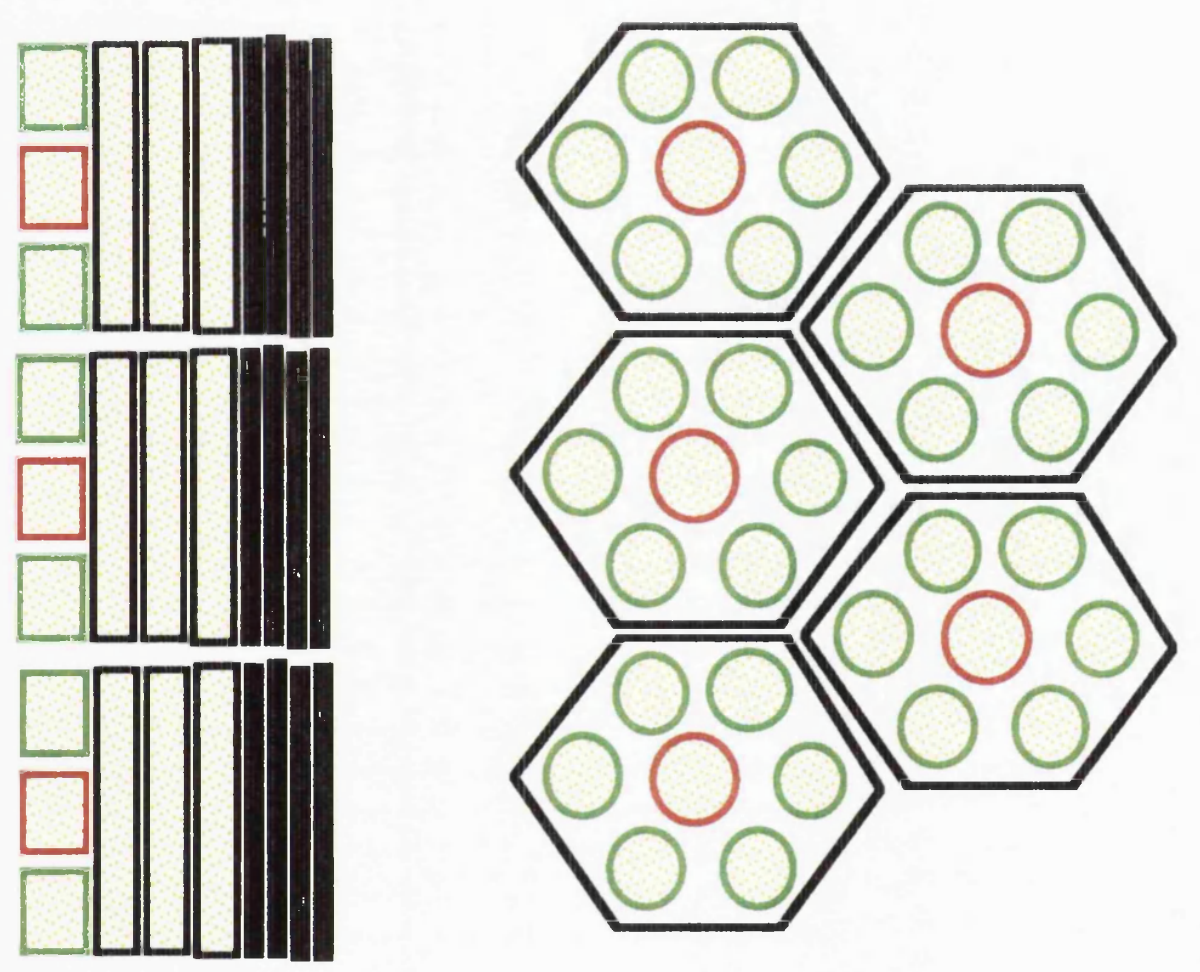


\section{FIGURE 1.14: Stochastic cell differentiation}

A Computer generated cell fate trees of haemopoietic cell differentiation.

Closed circles represent CFU-S that self renew, differentiating cells are shown by open circles. By assigning a probability of 0.4 to differentiation the model was able to reproduce the observed distribution of CFU-S in spleen colonies. Figure adapted from Till et al. (1964).

B Behaviour of keratinocytes in growing colonies in vitro followed by time lapse photography. Time is on the vertical axis, $S$ denotes cells lost from the field of view through differentiation and suprabasal migration. Note there is no relationship between the number of rounds of division and differentiation and that the 2 cell fate trees are markedly different. Figure adapted from Dover and Potten (1988). 
a
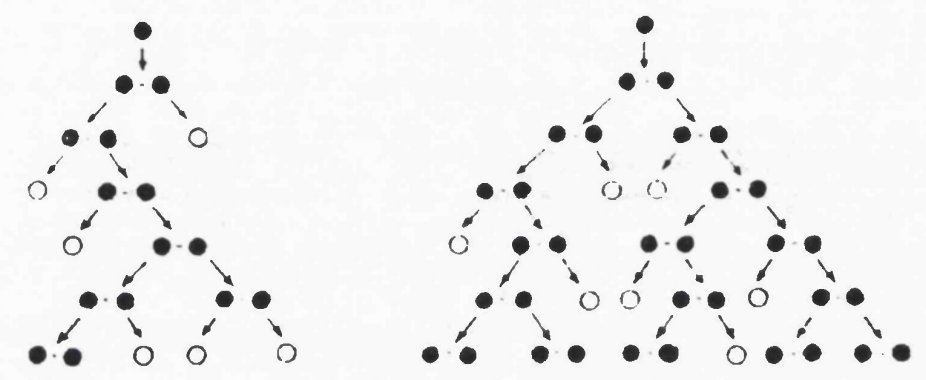

b
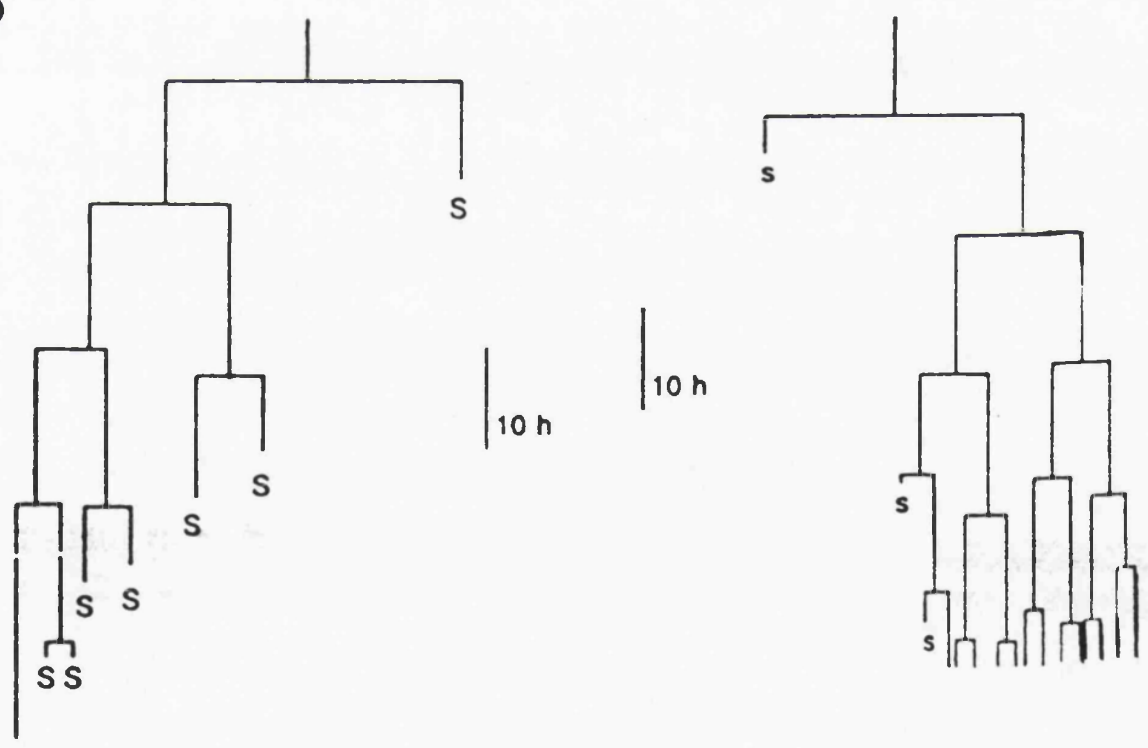


\section{CHA P T E R 2 \\ MATERIALS AND METHODS}

\section{CELLCULTURE AND NUDE MOUSE GRAFTS}

\section{Solutions and Media}

"ICRF" indicates the reagent was prepared by the Central Cell Services Unit at Imperial Cancer Research Fund, London.

\section{Phosphate Buffered Saline (PBS, ICRF)}

$8 \mathrm{~g} \mathrm{NaCl}, 2.5 \mathrm{~g} \mathrm{KCl}, 1.43 \mathrm{~g} \mathrm{NaH}_{2} \mathrm{SO}_{4}$ and $0.25 \mathrm{~g} \mathrm{KH}_{2} \mathrm{PO}_{4}$ were dissolved in 11 distilled water (d/w), the $\mathrm{pH}$ was adjusted to 7.2 and the solution autoclaved. PBSABC was PBS supplemented with $1 \mathrm{mM} \mathrm{CaCl} 2$ and $1 \mathrm{mMgCl}_{2}$.

\section{Trypsin Solution (5X stock, ICRF)}

$8 \mathrm{~g} \mathrm{NaCl}, 0.1 \mathrm{~g} \mathrm{Na}_{2} \mathrm{HPO}_{4}, 1 \mathrm{~g} \mathrm{D}$-glucose, $3 \mathrm{~g}$ Trizma base, $2 \mathrm{ml} 19 \%$ (w/v) $\mathrm{KCl}$ solution and $1.5 \mathrm{ml}$ of $1 \%(\mathrm{w} / \mathrm{v})$ phenol red were dissolved in $200 \mathrm{ml} \mathrm{d} / \mathrm{w}$, the $\mathrm{pH}$ was adjusted to 7.7 and $0.06 \mathrm{~g}$ penicillin and $0.1 \mathrm{~g}$ streptomycin were added. $2.5 \mathrm{~g}$ of pig trypsin (Difco, 1:250) was dissolved in $200 \mathrm{ml} \mathrm{d} / \mathrm{w}$; air was bubbled through the solution until the trypsin dissolved. The trypsin solution was added to the Tris saline solution, made up to 11 with $\mathrm{d} / \mathrm{w}$, filtered through a $0.2 \mu \mathrm{m}$ filter (Pall), bottled and stored at $-20^{\circ} \mathrm{C}$.

\section{EDTA solution (Versene, ICRF)}

$8 \mathrm{~g} \mathrm{NaCl}, 0.2 \mathrm{~g} \mathrm{KCl}, 1.15 \mathrm{~g} \mathrm{Na}_{2} \mathrm{HPO}_{4}, 0.2 \mathrm{~g} \mathrm{KH}_{2} \mathrm{PO}_{4}, 0.2 \mathrm{~g}$ ethyldiaminotetracetic acid (EDTA) and $1.5 \mathrm{ml} 1 \%$ phenol red solution were dissolved in $\mathrm{d} / \mathrm{w}$, the $\mathrm{pH}$ adjusted to 7.2 and the volume made up to 11 with $d / w$.

\section{Thermolysin solution}

$0.5 \mathrm{mg} / \mathrm{ml}$ Thermolysin (Sigma) was dissolved in a solution of $10 \mathrm{mM} \mathrm{N}$-[2hydroxyethyl]piperazine-N'-[2-ethanesulphonic acid] (HEPES), $142 \mathrm{mM} \mathrm{NaCl}$, $6.7 \mathrm{mM} \mathrm{KCl}, 0.43 \mathrm{mM} \mathrm{NaOH}, 1.0 \mathrm{mM} \mathrm{CaCl}_{2}$, pH 7.4 (Germain et al. 1993). 1/50th volume penicillin and streptomycin solution (Pen/strep, $10^{4} \mathrm{IU}$ penicillin/ml, $10^{4} \mu \mathrm{g}$ 
streptomycin/ml, Gibco BRL) was added, the solution passed through a $0.2 \mu$ filter (Costar) aliquoted and stored at $-20^{\circ} \mathrm{C}$.

\section{Keratinocyte growth medium (FAD/HICE/FCS)}

For 11 FAD medium (ICRF), 250ml Ham's F12 medium was added to $750 \mathrm{ml}$ Dulbecco's modification of Eagle's medium (DMEM). To this was added $20 \mathrm{ml}$ Pen/strep, $20 \mathrm{ml} 200 \mathrm{mM}$ glutamine solution (Gibco) and $24.3 \mathrm{mg}$ adenine dissolved in $5 \mathrm{mls} 0.005 \mathrm{M} \mathrm{HCl}$. The medium was gassed with $\mathrm{CO}_{2}$ until orange and then filtered through a $0.2 \mu \mathrm{m}$ filter, and stored at $4^{\circ} \mathrm{C}$.

Stock solutions of additives were prepared. $10^{-5} \mathrm{M}$ Cholera enterotoxin (CT, $1 \mathrm{mg}$ in $1.18 \mathrm{ml} \mathrm{d} / \mathrm{w}, \mathrm{ICN} / \mathrm{Flow}$ ) was stored at $4^{\circ} \mathrm{C}$. Hydrocortisone (HC, Calbiochem), was dissolved in ethanol at $5 \mathrm{mg} / \mathrm{ml}$ and stored at $-20^{\circ} \mathrm{C}$. $1 \mathrm{mg}$ epidermal growth factor (EGF, Austral Biologicals) was dissolved in $100 \mu \mathrm{l} 0.1 \mathrm{M}$ acetic acid (BDH) and then added to $10 \mathrm{ml}$ FAD medium containing $10 \%(\mathrm{v} / \mathrm{v})$ foetal calf serum (FCS, Imperial Laboratories) and stored at $-20^{\circ} \mathrm{C}$. Additives were combined into a $1000 \mathrm{x}$ cocktail (HICE): $100 \mu \mathrm{l} \mathrm{CT,} 1 \mathrm{ml} \mathrm{HC}$ and $1 \mathrm{ml}$ EGF stock solutions were added to $7.9 \mathrm{ml}$ FAD medium with $10 \%$ FCS and stored at $-20^{\circ} \mathrm{C} .1000 \mathrm{x}$ insulin stock solution $\left(5 \mathrm{mg} / \mathrm{ml}\right.$ in $0.005 \mathrm{M} \mathrm{HCl}$, Sigma) was stored at $-20^{\circ} \mathrm{C}$.

Complete keratinocyte medium (FAD/HICE/FCS) was prepared by adding $200 \mu \mathrm{l}$ cocktail, $200 \mu 1$ stock insulin solution (HICE) and $20 \mathrm{ml}$ FCS to $180 \mathrm{ml} \mathrm{FAD} \mathrm{medium}$ immediately prior to use. Complete medium was stored at $4^{\circ} \mathrm{C}$ for up to 5 days. In some experiments serum free medium (FAD/HICE) was used.

\section{$3 T 3$ culture medium}

This was DMEM (ICRF) with 10\% (v/v) added donor calf serum (DCS, Imperial Laboratories).

\section{Medium for suspension culture of keratinocytes}

3.3g methylcellulose (Mecel, viscosity 4000 centipoises, Aldrich Chemical Co.), was autoclaved in a $400 \mathrm{ml}$ centrifuge tube together with a magnetic stirrer bar. $200 \mathrm{ml}$ FAD medium with $10 \%$ FCS was heated to $60^{\circ} \mathrm{C}$, then added to the tube and the contents stirred at room temperature for 30 minutes and then at $4{ }^{\circ} \mathrm{C}$ overnight (Green 1977; Adams and Watt 1988). The tube was centrifuged for 30 minutes at 
$15000 \mathrm{xg}$, and the supernatant decanted into aliquots and stored at $-20^{\circ} \mathrm{C}$ until use. Immediately before use HICE was added as for keratinocyte medium.

\section{Primary Isolation of Keratinocytes}

Two methods were used, the first to obtain keratinocytes for in vitro culture and the second method for experiments requiring the use of keratinocytes isolated directly from foreskins. Keratinocytes were isolated from foreskins, mostly from neonates but occasionally from children up to 3 years in age, within 24 hours of circumcision. Specimens were kept dry at $4^{\circ} \mathrm{C}$ until use.

To obtain keratinocytes for in vitro cultivation, neonatal foreskins were washed extensively in PBSABC, and as much as possible of dermis removed from the epidermis by scraping with a scalpel. The epidermis was then cut into $5 \mathrm{~mm}$ diameter pieces and placed in a Wheaton Cellstir (Jencons) containing 1 volume 5x trypsin solution and 1 volume versene (Watt 1994a). The cells were incubated with stirring for 1-2 hours. The trypsin/versene solution was changed every 20 minutes; after removal the cells were washed with FAD/HICE/FCS, and plated into flasks, $10^{5}$ cells per $25 \mathrm{~cm}^{2}$ flask. Cells were cultured until just confluent, harvested, counted, aliquoted and frozen as described below. 1 flask of cells was sent to be tested for mycoplasma infection by the cell production unit at ICRF. Positive cells were discarded.

To obtain keratinocytes for experimental use, foreskins were washed extensively in PBSABC, dissected into $4-9 \mathrm{~mm}^{2}$ pieces, and placed in thermolysin solution either at $4^{\circ} \mathrm{C}$ overnight or at $37^{\circ} \mathrm{C}$ for 2 hours. The epidermis was then peeled away from the dermis with sterile fine forceps and placed in a Wheaton CellStir containing 15 $\mathrm{ml}$ trypsin/versene solution (1 volume $5 \mathrm{x}$ trypsin solution: 4 volumes versene), and stirred for 20-30 minutes at $37^{\circ} \mathrm{C}$, to form a single cell suspension. Cells were then washed in FAD/HICE/FCS or serum free FAD/HICE with soybean trypsin inhibitor (1ml of a $10 \mathrm{mg} / \mathrm{ml}$ solution to per $\mathrm{ml}$ of $5 \mathrm{x}$ trypsin solution, Sigma), and then used for experiments.

\section{Standard Keratinocyte Culture}

Keratinocytes were grown on a feeder layer of 3T3 cells, clone J2 (Rheinwald and Green 1975; Rheinwald 1989). 3T3 cells were cultured in DMEM/DCS until confluent, treated for 2 hours with $4 \mu \mathrm{g} / \mathrm{ml}$ mitomycin $\mathrm{C}$, harvested with versene 
and split $1: 3$ (i.e. to give a one third confluent cell density) into $25 \mathrm{~cm}^{2}$ or $75 \mathrm{~cm}^{2}$ tissue culture flasks (Falcon) containing FAD/HICE/FCS. Keratinocytes were seeded at densities of $2 \times 10^{4}-1 \times 10^{5}$ cells per flask, and cultured in a humidified $37^{\circ} \mathrm{C}$ incubator in a $5 \% \mathrm{CO}_{2}$ atmosphere. The medium was changed every $2-3$ days. Keratinocytes were harvested by removing the 3T3 cells with versene, adding trypsin/versene ( 1 volume of $5 x$ trypsin to 4 volumes of versene), incubating for $10-15$ minutes at $37^{\circ} \mathrm{C}$, and adding 9 volumes in FAD/HICE/FCS. For cell adhesion experiments, trypsin was neutralised by washing the cells in serum free FAD/HICE containing $1 \mathrm{mg} / \mathrm{ml}$ soybean trypsin inhibitor (Sigma). The cell suspension was then centrifuged at $400 \mathrm{xg}$ and the keratinocytes resuspended in FAD/HICE with or without serum as required.

\section{Ereezing of cells}

Freshly isolated or cultured cells were harvested, resuspended in FCS containing $10 \%$ dimethylsulphoxide (DMSO), placed in Nunc cryovials, frozen at $-80^{\circ} \mathrm{C}$ and stored in liquid nitrogen.

\section{Grafting cultured keratinocytes into nude mice}

Keratinocytes were harvested from neonatal foreskin. The cells adherent to type IV collagen within 5 minutes were isolated in $35 \mathrm{~mm}$ tissue culture dishes (Nunc) as described below. Feeder cells were added and the cells cultured until 2 days post confluence. The cultures were then washed with serum free E4. A solution of $0.5 \mathrm{mg} / \mathrm{ml}$ Dispase (Boehringer Mannheim) in E4 was passed through a $0.2 \mu \mathrm{m}$ filter (Costar) and added to the dish. After 45 minutes to 1 hour the sheet of confluent cells could be separated from the dish with sterile forceps. The cells were washed twice in FAD/HICE/FCS and once in serum free FAD/HICE. A $1.5 \mathrm{~cm} \times 1.5 \mathrm{~cm}$ sheet of Silastic was placed in contact with the suprabasal side of the sheet of keratinocytes. The Silastic was then inverted and placed within a skin flap in a female $\mathrm{Nu} / \mathrm{Nu}$ strain nude mouse and the flap closed with staples (see Figure 2.1, (Barrandon, et al. 1988). Surgery was performed by G Hutchinson, in the ICRF Animal Unit. After 7-8 days the animal was sacrificed and the graft removed. Grafts were cut in two with a cryotome blade. One piece was fixed in formol saline pH 7.0 and processed for paraffin sections by the Histopathology Unit, ICRF, and the other piece was used to prepare cryosections as described below. 


\section{IMMUNOLOGICAL METHODS}

\section{Tissue specimens}

Human neonatal foreskins, and cadaver scalp and palm were used. Post mortem specimens were collected and fixed within 24 hours of death. Specimens were not collected from bodies with cutaneous disease, systemic illnesses known to affect the skin such as uraemia, or if the cause of death was AIDS or hepatitis.

\section{Reagents}

\section{Gelvatol}

2.4g of gelvatol (Monsanto, (Harlow and Lane 1988)) was mixed with $6 \mathrm{~g}$ of glycerol (Sigma) and vortexed. $6 \mathrm{ml}$ of $\mathrm{d} / \mathrm{w}$ was added and the mixture left to stand for 90 minutes at room temperature. $12.5 \mathrm{ml}$ of $200 \mathrm{mM}$ Tris $\mathrm{pH} 8.5$ was then added and the solution vortexed, heated to $50^{\circ} \mathrm{C}$ and vortexed again. Heating and vortexing were repeated 3 times and the solution then placed on an end over end mixer overnight at room temperature. The solution was then centrifuged at $400 \mathrm{xg}$ for 10 minutes at room temperature and stored in aliquots at $4^{\circ} \mathrm{C}$.

\section{Citiflor}

Citiflor (Amersham) was prepared according to the Manufacturer's instructions.

\section{Paraformaldehyde}

A 5\% solution of paraformaldehyde (PFA, BDH)) was prepared by adding 5g PFA to $100 \mathrm{ml}$ PBS. The solution was heated to $60^{\circ} \mathrm{C}$ in a fume hood and $1 \mathrm{M} \mathrm{NaOH}$ added dropwise until the PFA had completely dissolved. Aliquots were then stored at $-20^{\circ} \mathrm{C}$.

\section{Antibodies}

Antibodies used are set out below (Tables 2.1, 2.2, 2.3). Optimal dilutions of all antibodies were titrated by staining tissue cryosections or by flow cytometry of cultured cells. 
Primary antibodies

Table 2.1: Anti integrin antibodies

\begin{tabular}{|c|c|c|c|c|}
\hline $\begin{array}{l}\text { Integrin } \\
\text { Subunit } \\
\text { Recognised }\end{array}$ & $\begin{array}{l}\text { Antibody } \\
\text { Name }\end{array}$ & Species & Source & Reference \\
\hline$\beta_{1}$ & CD29 & mouse & $\begin{array}{c}\text { Jansen } \\
\text { Biochime }\end{array}$ & $\begin{array}{l}\text { (Koenigsmann } \\
\text { et al. 1992) }\end{array}$ \\
\hline$\beta_{1}$ & $\begin{array}{l}\text { BD15 (FITC } \\
\text { conjugate }\end{array}$ & mouse & Serotec & \\
\hline$\beta_{1}$ & DH12 & mouse & $\begin{array}{l}\text { Gift from J } \\
\text { Cassiman }\end{array}$ & $\begin{array}{l}\text { (De Strooper et } \\
\text { al. 1988) }\end{array}$ \\
\hline$\beta_{1}+$ & $\mathrm{mAb} 13$ & rat & $\begin{array}{l}\text { Gift from K } \\
\text { Yamada, MIT, } \\
\text { Boston USA }\end{array}$ & $\begin{array}{l}\text { (Akiyama et al. } \\
1989)\end{array}$ \\
\hline$\alpha_{2}+$ & $5 \mathrm{E} 8$ & mouse & $\begin{array}{c}\text { Gift from R } \\
\text { Bankert, } \\
\text { Roswell Park } \\
\text { Memorial } \\
\text { Institute, } \\
\text { Buffalo, USA }\end{array}$ & $\begin{array}{l}\text { (Chen et al. } \\
1991)\end{array}$ \\
\hline$\alpha_{2}$ & Has 6 & mouse & $\begin{array}{l}\text { Keratinocyte } \\
\text { Laboratory, } \\
\text { ICRF }\end{array}$ & $\begin{array}{l}\text { (Tenchini, et al. } \\
\text { 1993) }\end{array}$ \\
\hline$\alpha_{3}$ & VM2 & mouse & $\begin{array}{l}\text { American } \\
\text { Tissue Culture } \\
\text { Collection }\end{array}$ & $\begin{array}{l}\text { (Kaufmann et } \\
\text { al. 1989) }\end{array}$ \\
\hline$\alpha_{5}+$ & BIIG2 & rat & $\begin{array}{l}\text { Gift from C } \\
\text { Damsky, }\end{array}$ & $\begin{array}{l}\text { (Werb et al. } \\
1989)\end{array}$ \\
\hline
\end{tabular}




\begin{tabular}{|c|c|c|c|l|}
\hline$\alpha_{5}+$ & mAb16 & rat & $\begin{array}{c}\text { Donated by K } \\
\text { Yamada, MIT, } \\
\text { Boston USA }\end{array}$ & $\begin{array}{l}\text { (Akiyama, et al. } \\
\text { 1989) }\end{array}$ \\
\hline$\alpha_{6}$ & GoH3 & rat & Serotec & $\begin{array}{c}\text { (Sonnenberg et } \\
\text { al. 1986) }\end{array}$ \\
\hline
\end{tabular}

NOTE: + adhesion blocking antibody

Table 2.2: Other antibodies

\begin{tabular}{|c|c|c|c|c|}
\hline $\begin{array}{c}\text { Antigen } \\
\text { Recognised }\end{array}$ & $\begin{array}{l}\text { Antibody } \\
\text { Name }\end{array}$ & Species & Source & Reference \\
\hline Keratins & LP34 & mouse & $\begin{array}{l}\text { Hybridoma } \\
\text { Unit, ICRF }\end{array}$ & $\begin{array}{l}\text { (Lane and } \\
\text { Alexander } \\
\text { 1990) }\end{array}$ \\
\hline Keratin 19 & LP2K & mouse & $\begin{array}{l}\text { Gift from I } \\
\text { Leigh, Royal } \\
\text { London } \\
\text { Hospital }\end{array}$ & $\begin{array}{l}\text { (Stasiak, Purkis } \\
\text { et al. 1989) }\end{array}$ \\
\hline Involucrin & DH1 & $\begin{array}{c}\text { rabbit } \\
\text { polyclonal }\end{array}$ & $\begin{array}{l}\text { Keratinocyte } \\
\text { Laboratory, } \\
\text { ICRF }\end{array}$ & $\begin{array}{l}\text { (Dover and } \\
\text { Watt 1987) }\end{array}$ \\
\hline Involucrin & SY3,SY5,SY7 & mouse & $\begin{array}{l}\text { Keratinocyte } \\
\text { Laboratory, } \\
\text { ICRF }\end{array}$ & $\begin{array}{l}\text { (Hudson et al. } \\
\text { 1992) }\end{array}$ \\
\hline CD3 & UCHT1 & mouse & $\begin{array}{c}\text { Jansen } \\
\text { Biochime }\end{array}$ & $\begin{array}{l}\text { (Beverly and } \\
\text { Callard 1981) }\end{array}$ \\
\hline $\mathrm{CD} 8$ & UCHT4 & mouse & Sigma & \\
\hline
\end{tabular}




\begin{tabular}{|l|l|l|l|l|}
\hline CD8 & $\begin{array}{c}\text { UCHT4, FITC } \\
\text { conjugate }\end{array}$ & mouse & Sigma & \\
\hline
\end{tabular}

\section{Secondary antibodies}

Table 2.3: Secondary antibodies

\begin{tabular}{|c|c|c|c|}
\hline $\begin{array}{c}\text { Antigen } \\
\text { Recognised }\end{array}$ & Conjugate & Species & Source \\
\hline $\begin{array}{c}\text { Mouse IgG, whole } \\
\text { molecule }\end{array}$ & FITC & Sheep & Sigma \\
\hline $\begin{array}{l}\text { Mouse IgG, whole } \\
\text { molecule }\end{array}$ & FITC & Rabbit & ICN \\
\hline $\begin{array}{l}\text { Rat IgG, whole } \\
\text { molecule }\end{array}$ & FITC & Rabbit & $\mathrm{ICN}$ \\
\hline $\begin{array}{l}\text { Rat IgG, whole } \\
\text { molecule }\end{array}$ & FITC & $\begin{array}{l}\text { Rabbit, Fab } \\
\text { fragments }\end{array}$ & Zymed \\
\hline $\begin{array}{l}\text { Rat IgG, whole } \\
\text { molecule }\end{array}$ & R Phycoerythrin & Goat & Calbiochem \\
\hline $\begin{array}{l}\text { Mouse IgG, whole } \\
\text { molecule }\end{array}$ & Biotin & Goat & Amersham \\
\hline $\begin{array}{l}\text { Rat IgG, whole } \\
\text { molecule }\end{array}$ & Biotin & Goat & Amersham \\
\hline $\begin{array}{l}\text { Rabbit IgG, whole } \\
\text { molecule }\end{array}$ & HRP & Goat & Sigma \\
\hline $\begin{array}{l}\text { Mouse IgG, whole } \\
\text { molecule }\end{array}$ & HRP & Goat & Sigma \\
\hline
\end{tabular}

NOTE - FITC - Fluorescein isothiocyantate, HRP - Horse Raddish Peroxidase 


\section{Streptavidin Tricolor}

A streptavidin conjugate of the fluorochrome Tricolor (Caltag, Bradshaw Biologicals) was used in 3 colour labelling.

Tricolor has an absorption peak at $488 \mathrm{~nm}$ and an emission peak at over $650 \mathrm{~nm}$. This means the tricolor fluorescent signal can be separated from the signals of FITC (absorption peak $488 \mathrm{~nm}$, emission peak $520 \mathrm{~nm}$ ) and $\mathrm{R}$ phycoerythrin (which has absorption peak at $550 \mathrm{~nm}$, but is excitable at $488 \mathrm{~nm}$ and an emission peak at $560 \mathrm{~nm}$ ). Thus 3 colour flow cytometry can be performed with a single $488 \mathrm{~nm}$ laser.

\section{Peanut agglutinin (PNA)}

Biotinylated and FITC conjugated forms of the lectin PNA were obtained from Vector. Cells were stained with PNA using the same conditions as for antibody staining.

\section{Biotinylation of antibodies}

The anti $\alpha 3$ integrin subunit antibody VM2 was biotinylated for use in 3 colour labelling experiments (Gretch et al. 1987; Harlow and Lane 1988). 10mg of purified IgG was concentrated to $10 \mathrm{mg} / \mathrm{ml}$ using an Amicon B15 minicon concentrator and passed through a Pharmacia PD10 column pre equilibrated with $50 \mathrm{mM} \mathrm{NaHCO} 3$ buffer $\mathrm{pH} 8.5$. The eluate was again concentrated to $10 \mathrm{mg} / \mathrm{ml}$ using a minicon concentrator. $1 \mathrm{mg}$ of NHS LC biotin (Pierce) was then added in $80 \mu l$ of $d / w$ and incubated on ice for 2 hours. The free biotin was removed by making the volume of the mixture up to $5 \mathrm{ml}$ with $\mathrm{PBS}$, concentrating the sample to $100 \mu \mathrm{l}$ in a minicon concentrator and then adding a further 5ml PBS and repeating the concentration step. The antibody was then recovered, diluted to $2 \mathrm{mg} / \mathrm{ml}$, passed through a $0.2 \mu \mathrm{m}$ filter (Costar) and stored at $4^{\circ} \mathrm{C}$.

\section{Antibody conjugation to fluorescein}

Two methods were used. Conjugation of FITC to HAS6 and VM2 antibodies was by the method described by Goding (Goding 1976). 5mg of each antibody was concentrated into $0.5 \mathrm{ml}$ volume with a minicon concentrator. 4-6 drops of $0.1 \mathrm{M}$ $\mathrm{Na}_{2} \mathrm{CO}_{3}$ buffer were then added to bring the $\mathrm{pH}$ to 9.5 . $0.5 \mathrm{mg}$ of FITC/ polystyrene 
mixture (Sigma) was added to each antibody and the solution placed on an end over end mixer for 2 hours at room temperature. Free FITC was removed with a PD10 column (Pharmacia) pre equilibrated with PBS, according to the Manufacturer's instructions. The antibody was eluted in PBS and stored at $4^{\circ} \mathrm{C}$.

To conjugate GoH3 (Serotec) $300 \mu \mathrm{l}$ of antibody $(0.2 \mathrm{mg} / \mathrm{ml})$ was placed in a $1.5 \mathrm{ml}$ Eppendorf tube; dialysis membrane (Spectrapore no. 1, MW cutoff 6000-8000) was placed over the open end of the tube and secured with a rubber band. The antibody then dialysed against $800 \mathrm{ml} \mathrm{d} / \mathrm{w}$. The sample was evaporated to dryness over 90 minutes in a Speedvac freeze dryer. The pellet was resuspended in $30 \mu \mathrm{l} 0.1 \mathrm{M}$ $\mathrm{Na}_{2} \mathrm{CO}_{3}$ buffer $\mathrm{pH}$ 9.0. FITC (Sigma) was dissolved in DMSO (Sigma) at $1 \mathrm{mg} / \mathrm{ml}$; $3 \mu \mathrm{l}$ of this solution were added slowly to the antibody and mixture left at $4^{\circ} \mathrm{C}$ overnight (Harlow and Lane 1988). The free FITC was removed by dialysing against 3 changes of $500 \mathrm{ml}$ each of PBS over 8 hours in an Eppendorf tube as before. The antibody was diluted to $100 \mathrm{ml}$ with PBS, sodium azide added to $0.02 \%$ and $\mathrm{BSA}$ to $1 \%$ and the antibody stored at $4^{\circ} \mathrm{C}$.

\section{Immunofluorescent staining of cells}

Cells air dried onto coverslips were fixed with $3.7 \%$ formaldehyde, permeabilised with methanol, rinsed in PBS, and incubated with an anti involucrin antibody for 30 minutes at room temperature (Read and Watt 1988). After extensive washing in PBS the appropriate second layer antibody was added and incubated for 30 minutes at room temperature. The cells were washed again in PBS, mounted in Gelvatol and examined and photographed using a Zeiss Axiophot microscope.

The same method was used to stain cells for keratins with LP34 anti keratin antibody and for the $\beta 1$ integrin subunit using anti CD29 first antibody except that the methanol permeabalisation step was omitted when staining for integrins.

\section{Immunofluorescent staining of tissue sections}

Tissue was frozen in an isopentane (BDH, Poole, Dorset, UK) bath in liquid nitrogen, embedded in O.C.T. compound (BDH) and cryosectioned into $6 \mu \mathrm{m}$ sections. Frozen sections of palm, scalp and neonatal foreskin were incubated with $10 \%$ foetal calf serum (FCS) in PBSABC for 30 minutes. Sections were then incubated for 30 minutes with antibodies conjugated to FITC diluted in 10\% FCS in PBSABC, washed extensively in PBSABC, fixed in 1\% paraformaldehyde (PFA), 
washed again in PBSABC and mounted in Citiflor or in Gelvatol. For double labelling of keratin 19 and integrins in hair follicles staining was as above but sections were incubated first with LP2K, washed, incubated with an anti-mouse IgG rhodamine conjugate, washed and then incubated with directly conjugated anti integrin antibody. Tissue sections were examined using a BioRad MRC 600 confocal microscope (BioRad, Watford, Herts UK), using the $25 x$ objective with an optical section thickness of $1 \mu \mathrm{m}$, or photographed using a Zeiss Axiophot microscope.

\section{Quantification of fluorescence on tissue sections and keratinocyte cultures}

To quantification of fluorescence of tissue sections or keratinocyte cultures stained with anti integrin antibodies conjugated to FITC was by confocal microscopy. The $25 \mathrm{x}$ objective was used with an optical section thickness of $1 \mu \mathrm{m}$.

For tissue sections only rete ridges and dermal papillae in which all the cell borders of all basal cells could be seen were included to ensure against artefacts due to the plane of sectioning. Basal cells were scored as either bright or dull by eye. The size of integrin-bright and -dull patches was calculated from at least 30 rete ridges (deep rete ridges in palm) and 30 dermal papillae for each body site and for each subunit. The fluorescence of at least 100 cells in dull and bright patches was determined. Fluorescence of the $\alpha_{2}$ and $\alpha_{3}$ subunits was quantitated from the confocal image by measuring pixel intensity along a line drawn through the lateral cell-cell borders. In contrast to the $\alpha_{2}$ and $\alpha_{3}$ subunits the $\alpha_{6}$ integrin subunit was found principally on the basal surface of the cells and so expression was measured on the basal surface.

The fluorescence of cultured keratinocyte sheets labelled with fluorescein conjugated antibodies to the $\alpha_{2}$ or $\alpha_{3}$ integrin subunits was also determined. In vertical sections, the ratio of fluorescence between integrin-bright and -dull patches was calculated as described above for tissue sections; the fluorescence of over 50 cells in dull and bright patches was determined. To determine patch size, sections were viewed on the confocal microscope. The histogram function was used to colour cells according to intensity fluorescence. The fluorescence was measured on a scale from 0 to 254 arbitrary fluorescence units. This scale was divided into 6 bands, increasing in intensity from band 1 to band 6 . The bands were of equal width apart from the lowest one, which was set just to colour the dullest staining 
cell membranes. Cells which contained regions coloured with bands $3 / 4$ for $\alpha_{2}$ (the brightest staining seen with this subunit) or bands $5 / 6$ for $\alpha_{3}$ were scored as bright. Dull cells were coloured by bands $1 / 2$ for $\alpha_{2}$ and $1-3$ for $\alpha_{3}$ and contained no areas of more intense staining. At least 50 patches in each specimen were analysed. For whole mounts, a series of $1 \mu \mathrm{m}$ optical sections through the entire thickness of the sheet was obtained using the $25 \mathrm{x}$ objective of the confocal microscope. A composite image ( $\mathrm{Z}$ series) was constructed from these sections.

\section{Immunohistochemical staining of colonies}

Dishes were fixed in $3.7 \%$ formaldehyde (10 minutes at room temperature) followed by methanol containing $0.18 \%$ hydrogen peroxide (Fisons) ( 5 minutes on ice). The dishes were incubated in 10\% FCS in PBSABC for 30 minutes at room temperature to prevent non-specific binding and washed in PBS. Dishes were then incubated sequentially with the SY3 anti involucrin antibody, anti mouse-HRP, diaminobenzidine (DAB) $(0.5 \mathrm{mg} / \mathrm{ml}$ in PBS containing $0.02 \%$ cobalt chloride; $\mathrm{Hsu}$ and Soban 1982), LP34, an keratin antibody, anti mouse-HRP and 4 amino 9 ethyl carbazole $(0.4 \mathrm{mg} / \mathrm{ml}$ in acetate buffer according to the manufacturers instructions, Sigma). Dishes were washed extensively in PBSABC between incubations and antibodies were diluted in 10\% FCS in PBSABC. With this staining protocol, keratinocytes that lacked involucrin were stained red and keratinocytes that expressed involucrin were stained blue-black.

\section{Elow cytometry}

Cells were resuspended in PBSABC at $4^{\circ} \mathrm{C}$ and filtered through a $63 \mathrm{~mm}$ nylon mesh (R. Cadish and Sons, London, UK). For immunofluorescent labelling cells were incubated on ice with a saturating concentration of FITC conjugated antibody for 10-20 minutes. The cells were then washed in cold PBSABC $\left(4^{\circ} \mathrm{C}\right)$ and either analysed immediately or fixed in $1 \%$ paraformaldehyde in PBS. Immediately before analysis of unfixed cells propidium iodide (PI, $5 \mu \mathrm{g} / \mathrm{ml}$, Sigma) was added for viability gating (Krishan 1975).

Cells were analysed for integrin expression using a Becton-Dickinson FACScan and sorted on a Becton-Dickinson FACStar Plus. In both machines excitation of fluorochromes was via a single $488 \mathrm{~nm}$ argon laser. At least 10,000 events were acquired in list mode for each sample. With unfixed samples cells positive for PI were gated out. For sterile sorts the FACStar plus was flushed through with $7 \mathrm{X}$ 
detergent for 60 minutes, followed by $70 \%$ ethanol for 30 minutes and then penicillin, streptomycin and gentamicin for 30 minutes (Gibco BRL) before use.

For single colour cell sorting of cells stained with FITC conjugates, gates were set using forward light scatter (FSC), side light scatter (SSC), and the FL3 channel was used to gate out PI positive cells. The FL 3 channel had a $620 \mathrm{~nm}$ long pass filter on the FACScan and a 650-670nm band pass filter on the FACStar plus. The FITC signal was detected on the FL1 channel (520nm to $560 \mathrm{~nm}$ band pass filter). The same filter arrangement was used for 2 colour analysis of cells stained with anti integrin subunit antibodies detected with FITC and PNA detected with tricolor, adjusting the gain on the FL3 channel amplifier to allow resolution of the PNA signal from the brighter PI signal used for viability gating. In 3 colour experiments the FACStar plus was used. The FITC signal was detected with the FL1 channel, the R-Phycoerythrin signal with the FL2 channel (580nm long pass and 640nm short pass filters) and the tricolor and PI signals with the FL3 channel.

In experiments for determining colony forming efficiency cells were sorted directly into $60 \mathrm{~mm}$ diameter dishes (100 cells /dish) using the Automatic Cell Deposition Unit facility on the FACStar plus. Dishes were seeded with mitomycin C treated feeder cells 24 hours before use. In some experiments cells were also sorted for involucrin staining and examination of cell size (2-5x105 cells per tube)

\section{CELLADHESIONMETHODS}

\section{Extracellular matrix proteins}

\section{Type IV Collagen}

Human placental type IV collagen (Sigma) was dissolved in sterile filtered $0.25 \%$ acetic acid at $2 \mathrm{mg} / \mathrm{ml}$ by placing on an end over end mixer at $4^{\circ} \mathrm{C}$ for $2-4$ hours. The solution was then stored at $-20^{\circ} \mathrm{C}$ and thawed at room temperature.

\section{Laminin}

Mouse Engelbreth-Holm-Swarm sarcoma derived laminin (EHS laminin) was purchased from Sigma, stored at $-80^{\circ} \mathrm{C}$ and thawed at $4{ }^{\circ} \mathrm{C}$ prior to use.

\section{Fibronectin}


Human plasma derived fibronectin was obtained from BPL, stored at $-20^{\circ} \mathrm{C}$ and thawed at $37^{\circ} \mathrm{C}$ for 2 hours.

\section{Keratinocyte extracellular matrix}

Keratinocytes were grown to confluence under standard culture conditions, washed with cold PBS, and then placed at $4^{\circ} \mathrm{C}$ for 20 minutes in $10 \mathrm{mM}$ EDTA, $25 \mathrm{mM}$ Tris $\mathrm{HCl}$ and 1\% Triton X-100 (Sigma, Rousselle et al. 1991). The keratinocyte lysate was then removed, the culture dishes washed extensively in cold PBSABC, and used immediately.

\section{Adhesion to ECM proteins}

\section{Coating dishes and plates}

Petri dishes (Falcon) were coated overnight at $4^{\circ} \mathrm{C}$ with ECM proteins in PBSABC, using the concentrations of each protein shown below, incubated with $0.5 \mathrm{mg} / \mathrm{ml}$ heat denatured BSA (Sigma) in PBSABC at $37^{\circ} \mathrm{C}$ for 1 hour and washed in serumfree medium before use. Bacteriological plastic dishes were used in experiments in which adherent cells were to be subsequently removed and tissue culture plastic dishes used in experiments where adherent cells were cultured in the same dish.

\section{Adhesion blocking experiments}

For antibody adhesion blocking experiments 96 well bacteriological plastic plates (Falcon) were coated overnight at $4^{\circ} \mathrm{C}$ with type IV collagen $(100 \mathrm{mg} / \mathrm{ml}$ in PBSABC) or with PBSABC alone as in the control. Wells were then incubated with $0.5 \mathrm{mg} / \mathrm{ml}$ heat denatured bovine serum albumin (Sigma) in PBSABC for 1 hour at $37^{\circ} \mathrm{C}$. $10^{4}$ cells freshly isolated from neonatal foreskin epidermis were then plated onto control and collagen coated wells, either alone or with one of the following antibodies: mAb 13, DH12, HAS6, 5E8. After $1 \mathrm{hr}$ the wells were rinsed with PBSABC, fixed with $3.7 \%$ formaldehyde and counted after staining with $1 \%$ methylene blue.

\section{DETERMINATIONOF COLONYFORMING EFEICIENCY}

Cells harvested for adhesion experiments were recovered from trypsin/EDTA by centrifugation in the presence of soybean trypsin inhibitor $(1 \mathrm{mg} / \mathrm{ml})$ (Sigma), washed in serum free medium and counted with a haemocytometer. The cells were 
plated onto dishes coated with type IV collagen. At intervals dishes were washed with serum free medium and 3T3 feeder cells were added to the coated dishes. For flow cytometry, adherent cells were harvested by incubation with versene at $4^{\circ} \mathrm{C}$. To determine the number of cells attached duplicate dishes were prepared and the number of adherent cells counted after staining with the anti keratin antibody LP34 visualised with DAB as described above. Dishes were cultured for 2 weeks in colony forming experiments, and colonies then stained with anti involucrin and anti keratin antibodies.

In experiments to determine the fate of cells which adhered to type IV collagen but did not form colonies larger than 32 cells in size, cells were allowed to attach to collagen coated dishes for 5 minutes. The cells which did not attach were transferred to another collagen coated dish, feeders added and the cells cultured as above. Dishes were fixed and stained for involucrin and LP34 at 3 hours and 1, 3, 5,7 and 14 days. The size and number of colonies were counted using a Leitz inverted microscope.

Control colony forming efficiencies were expressed as the percentage of basal cells plated; for cultured cells this was calculated by multiplying the number of cells plated by the proportion of involucrin-negative cells in the population and for freshly isolated cells by multiplying the number of cells plated by the proportion of integrin-positive and keratin-positive cells in the population.

\section{SUSPENSIONINDUCED TERMINAL DIEEERENTIATION}

Keratinocytes can be induced to undergo differentiation by placing them in suspension culture in medium made viscous with methyl cellulose (Green 1977; Watt 1994b). As cell numbers were limited, the cells were cultured in drops of methyl cellulose on coverslips.

Cultured keratinocytes were harvested and $10^{5}$ cells were placed in $1 \mathrm{ml}$ of suspension culture medium onto $35 \mathrm{~mm}$ coverslips which had been siliconised by being dipped in Repelcote (BDH), washed in $\mathrm{d} / \mathrm{w}$ and autoclaved. The coverslips were placed in a humidified incubator for 24 hours at $37^{\circ} \mathrm{C}$ when the cells were scraped from the coverslips, washed twice in 50ml PBSABC, resuspended in FAD/FCS/HICE and air dried onto multiwell slides or coverslips (previously 
washed in $7 \mathrm{X}$ detergent (Flow Laboratories) followed by $\mathrm{d} / \mathrm{w}$ ). Cells were then stained for involucrin.

\section{CELL FATE STUDIES}

Cells were labelled with the fluorescent dye PKH26, using the red fluorescent cell labelling kit (Sigma), according to the Manufacturer's instructions. PKH26 has 2 excitation maxima, at $515 \mathrm{~nm}$ and $551 \mathrm{~nm}$, and an emission maximum at $567 \mathrm{~nm}$. $2.5 \times 10^{6}$ cells were labelled in $1 \mathrm{ml} 5 \mu \mathrm{M}$ PKH26 solution. The viability of labelled cells was checked by PI exclusion and found to be in excess of $90 \%$.

Labelled keratinocytes were allowed to adhere to 8 chamber tissue culture plastic slides (1000 cells per well) and $35 \mathrm{~mm}$ diameter dishes ( $2 \times 10^{4}$ cells per dish), coated with $100 \mu \mathrm{g} / \mathrm{ml}$ type IV collagen and blocked with BSA as described above. After 20 minutes, non adherent keratinocytes were removed, feeder cells were added and the cells cultured for 1,3,5,7 and 9 days by which time the cultures were confluent. Colonies on the 8 chamber slides were stained with VM2-FITC antibody, fixed in $1 \%$ paraformaldehyde and examined on the confocal microscope. A series of optical sections was taken through each colony, and the images superimposed (in a " $\mathrm{Z}$ series") and photographed. Cells in dishes were harvested, stained for VM2 and analysed by flow cytometry using the FACStar plus: one laser was tuned to $488 \mathrm{~nm}$ (to excite FITC) and the other was tuned to $515 \mathrm{~nm}$ to excite the PKH26.

\section{CellakineuCs}

\section{Histone in situ hybridisation}

\section{Fixation}

Formol Saline (ICRF) was prepared by dissolving $5 \mathrm{~g} \mathrm{NaCl}$ and $15 \mathrm{~g}$ of $\mathrm{Na}_{2} \mathrm{SO}_{4}$ in $800 \mathrm{ml}$ of distilled water. $100 \mathrm{ml} 40 \%$ formaldehyde solution was filtered through Whatman $113 \mathrm{~V}$ filter paper and then added to the salt solution. The final volume was made up to 11 with distilled water. The $\mathrm{pH}$ was adjusted to 7.0.

Specimens were fixed in formol saline for 24 hours.

\section{In situ hybridisation}


$6 \mu \mathrm{m}$ paraffin sections of each specimen were cut by the department of Histopathology, Leicester General Hospital, Leicester UK. In situ hybridisation for mRNA of histones 2B, 3 and 4 was performed by Dr S Harper, Leicester General Hospital, Leicester, UK, using a cocktail of nine different, 30 base deoxyoligonucleotides, in which 3 oligonucleotides were complementary to each histone gene. The method used was a modified version of that developed by Pringle (Pringle et al. 1990). Deoxynucleotide design (UK patent no. 9220777.8) was based on previously published sequence data (Zhong et al. 1983). Sections were dewaxed with fresh xylene, rehydrated through graded alcohols and treated with proteinase $\mathrm{K}, 2-10 \mu \mathrm{g} / \mathrm{ml}$, (Boehringer Mannheim, Lewes, E Sussex, UK). Samples were post fixed in $0.4 \%$ paraformadlehyde in PBS. Probe cocktails were $3^{\prime}$ labelled with digoxigenin-11-deoxyuridine triphosphate using terminal deoxynucleotidyl transferase (Boehringer Mannheim). Samples were hybridised overnight at $37^{\circ} \mathrm{C}$ with $200 \mathrm{ng}$ probe cocktail per $\mathrm{ml}$ of hybridisation solution. The hybridisation solution consisted of $600 \mathrm{mM}$ sodium chloride, 1xpolyvinylpyrrodilone.EDTA (unmodified, Sigma), 10\% dextrose sulphate (Sigma), 30\% formamide (Fisons, Loughborough, UK). Posthybridisation washes were as follows: $2 \times \mathrm{SSC} / 30 \%$ formamide, twice, 10 minutes each wash at $37^{\circ} \mathrm{C} ; 2 \times S S C$ at room temperature, twice, 10 minutes each; one 15 minute wash in blocking solution (3\% BSA, $0.1 \%$ Triton-X-100 (Sigma), in Tris buffered saline). Hybrids were detected using an alkaline phosphatase conjugated sheep polyclonal anti-digoxigenin antibody (Boehringer Mannheim) diluted in blocking solution. Alkaline phosphatase was visualised by overnight incubation with a substrate solution comprising: $10 \mathrm{ml} 0.6 \mathrm{M}$ Tris-HCL pH 9.5 (Fisons) in $0.6 \mathrm{M}$ sodium chloride and $0.3 \mathrm{M}$ magnesium chloride; $44 \mu \mathrm{l}$ nitroblue tetrazoleum (Sigma, $75 \mathrm{mg} / \mathrm{ml}$ in $70 \%$ dimethylformamide); $33 \mu \mathrm{l} \mathrm{5-}$ bromo-4-chloro-3-indolyl phosphate (Sigma, $50 \mathrm{mg} / \mathrm{ml}$ in dimethylformamide), $10 \mu 1$ 1M levamisole (Sigma). Positive cells stained dark purple.

Several negative controls were performed on different specimens from each site. Four controls were used for the hybridisation step. RNAse A1 (Sigma) pretreatment was used to degrade RNA. The probe was omitted altogether. A digoxigenin labelled random 30 base oligonucleotide cocktail was used in the place of the histone probes (unlabelled oligonucleotides were a gift from Pathway services Leicester, UK). Finally a digoxigenin labelled non homologous probe cocktail to immunoglobulin kappa light chain mRNA, containing nine deoxyoligoprobes all 30 bases in length with the same guanine-cytosine content as the histone cocktail (55\%), was substituted for the histone probes. As a control for non specific antibody binding the alkaline phosphatase reaction was performed with 
no antidigoxigenin antibody. No positively stained cells were seen with any negative control.

The sections were analysed by myself. Each section was photographed under phase contrast on a Ziess Axiophot microscope and the total number of basal cells and positively stained basal cells counted in the areas corresponding to bright integrin staining patches in each site, ie. the most superficial 13 cells in foreskin or 9 cells in scalp in each dermal papilla, and in the intervening regions corresponding to areas with dull integrin staining. All basal cells in all regions that were vertically sectioned were counted, areas that were not vertically sectioned were excluded.

\section{Tritiated thymidine incorporation in keratinocyte cultures}

Post confluent cultures of neonatal foreskin keratinocytes were incubated with FAD/HICE/FCS medium containing $20 \mu \mathrm{Ci} / \mathrm{ml}$ added tritiated thymidine (specific activity $25 \mathrm{Ci} / \mathrm{mmol}$, Amersham) for $1 \mathrm{hr}$. The cells were then harvested, washed in PBSABC, and stained with HAS6-FITC antibody, washed in PBSABC and fixed in $1 \%$ paraformaldehyde solution. Cells were then sorted into 3 groups: the $20 \%$ with highest integrin expression, the mid $40 \%$ of the population and the $20 \%$ with lowest expression. After sorting, cells were centrifuged and resuspended in 5\% Trichoroacetic acid (TCA, BDH), containing 1\% sodium pyrophosphate (Sigma), and placed at $4^{\circ} \mathrm{C}$ for 30 minutes. The solution was then passed through a Whatman GF/C glass fibre filter which was then washed with 10\% TCA followed by ice cold absolute ethanol. The TCA precipitable counts on each disc were measured in Ecolume scintillant using a Beckton-Dickinson scintillation counter.

\section{MOLECULAR BIOLOGY}

\section{Solutions}

Unless otherwise stated methods were taken from Sambrook et al., (Sambrook et al. 1989).

\section{DEPC water}

Diethyl pyrocarbonate (DEPC) (Sigma) was added to distilled water (d/w) to a final concentration of $0.1 \%$, and autoclaved. 


\section{Guanidinium thiocyanate (GIT) solution}

$189 \mathrm{~g}$ GIT (BRL), $10 \mathrm{ml} 1 \mathrm{M}$ sodium citrate $(\mathrm{BDH}), 2.8 \mathrm{ml} \beta$-mercaptoethanol (Sigma) and $6.7 \mathrm{ml} 30 \%$ sodium $\mathrm{N}$ lauryl sarcosine (Sigma) were made up to $400 \mathrm{ml}$ with $d / w$, filtered through Whatman number 1 filter paper, aliquoted and frozen at $-20^{\circ} \mathrm{C}$.

\section{Caesium chloride /EDTA solution-(CsCl2/EDTA)}

96.0 $\mathrm{g}_{\text {of }} \mathrm{CsCl}_{2}$ (BRL) was dissolved in $90 \mathrm{ml}$ of $0.01 \mathrm{M}$ EDTA pH 7.5, DEPC added to a final concentration of $0.1 \%$, and the solution autoclaved. After autoclaving, the volume was adjusted to $100 \mathrm{ml}$ with DEPC treated water.

\section{Tris/EDTA solution (TE)}

Tris base (Sigma) was dissolved in $1 \mathrm{mM}$ EDTA to a concentration of $10 \mathrm{mM}$ and the $\mathrm{pH}$ adjusted to 7.6 .

\section{Sodium acetate solution $(\mathrm{NaOAc})$}

A $3 \mathrm{M}$ solution was prepared by dissolving $40.8 \mathrm{~g}$ of sodium acetate. $3 \mathrm{H}_{2} \mathrm{O}$ in $80 \mathrm{ml}$ $\mathrm{d} / \mathrm{w}$, adjusting the $\mathrm{pH}$ to 5.2 with glacial acetic acid. The volume was made up to $100 \mathrm{ml}$ with $\mathrm{d} / \mathrm{w}$ and the solution autoclaved.

\section{Solutions for DNA minipreps}

Solution I: a solution of $50 \mathrm{mM}$ glucose and $10 \mathrm{mM}$ EDTA in $25 \mathrm{mM}$ Tris- $\mathrm{HCl} \mathrm{pH}$ 8.0.

Solution II: a freshly prepared solution of $0.2 \mathrm{M}$ sodium hydroxide and $1 \%$ sodium dodecyl sulphate (SDS, BDH).

Solution III: Potassium hydroxide pellets were added to $29.5 \mathrm{ml}$ glacial acetic acid $(\mathrm{BDH})$ to give a $\mathrm{pH}$ of 4.8 and diluted to $100 \mathrm{ml}$ with $\mathrm{d} / \mathrm{w}$.

\section{Ammonium acetate solution $\left(\mathrm{NH}_{4} \mathrm{OAc}\right)$}


7.5 M Ammonium acetate was prepared in DEPC water and the solution filtered through a $0.22 \mu \mathrm{m}$ filter (Nalgene).

\section{Tris-Acetate EDTA buffer (TAE)}

A 50x stock solution was prepared by dissolving $242 \mathrm{~g}$ Tris base in $57.1 \mathrm{ml}$ glacial acetic acid and $100 \mathrm{ml} 0.5 \mathrm{M}$ EDTA (pH 8.0), making the volume up to 11 with $\mathrm{d} / \mathrm{w}$. When diluted this gave $0.04 \mathrm{M}$ tris-acetate in $1 \mathrm{mM}$ EDTA.

\section{Tris-Borate-EDTA buffer (TBE)}

A 10x stock solution was prepared by dissolving $54 \mathrm{~g}$ Tris base and $27.5 \mathrm{~g}$ acetic acid in $20 \mathrm{ml} 0.5 \mathrm{M}$ EDTA. The volume was made up to $11 \mathrm{with} \mathrm{d} / \mathrm{w}$. When diluted this gave $0.045 \mathrm{M}$ Tris-borate in $1 \mathrm{mM}$ EDTA.

\section{DNA loading buffers}

For conventional electrophoresis (in TAE or TBE) 10x loading buffer comprised $20 \%$ Ficoll 400 (Sigma), 0.1M EDTA pH 8.0, 1\% SDS, 0.25\% bromophenol blue (Sigma) and $0.25 \%$ xylene cyanol (Sigma) in distilled water.

For alkaline gel electrophoresis $10 \mathrm{x}$ loading buffer comprised $30 \mathrm{mM}$ sodium hydroxide, 1mM EDTA, 10\% (v/v) glycerol (Sigma) and 0.01\% bromophenol blue (BDH).

\section{0x Klenow buffer}

A solution of $0.1 \mathrm{M}$ magnesium chloride in $0.5 \mathrm{M}$ Tris. $\mathrm{Cl} \mathrm{pH}$ 7.6.

\section{Solutions for replica plating on Hybond $\mathbf{N}$ filters}

Denaturing solution was $1.5 \mathrm{M} \mathrm{NaCl}, 0.5 \mathrm{M} \mathrm{NaOH}$. Neutralising solution was $1.5 \mathrm{M}$ $\mathrm{NaCl}, 0.5 \mathrm{M}$ Tris- $\mathrm{HCl} \mathrm{pH} 7.4,0.001 \mathrm{M}$ EDTA.

\section{SSC Buffer}

20x SSC was $3 \mathrm{M} \mathrm{NaCl}, 0.3 \mathrm{M}$ sodium citrate $\mathrm{pH} 7.0$. 


\section{Solutions for Southern blotting}

Prehybridisation (Prehyb) solution was $200 \mathrm{mM}$ sodium phosphate buffer $\mathrm{pH} 7.0$, $1 \mu \mathrm{M}$ ETDA, 1\% BSA, 7\% SDS (Church and Gilbert 1984). Freshly boiled, sonicated salmon sperm DNA (Sigma) was added to $100 \mu \mathrm{g} / \mathrm{ml}$ immediately before use. The same solution was used for hybridisations.

\section{Solutions for polyacylamide gel electrophoresis of protein}

Proteins from in vitro translation experiments were electrophoresed as described by Laemmli (Lammeli 1970).

Solution A: $30 \%$ acrylamide (w/v) with $0.8 \%(w / v)$ bis acrylamide (Scotlab)

Solution B: $1.5 \mathrm{M}$ Tris. $\mathrm{HCl} \mathrm{pH} 8.8$, stored at $4^{\circ} \mathrm{C}$

Solution C: $10 \%$ SDS in $d / w$

Solution D: $0.5 \mathrm{M}$ Tris pH 6.8 , stored at $4^{\circ} \mathrm{C}$

$2 \mathrm{x}$ sample buffer was made up of $2.5 \mathrm{ml}$ solution $\mathrm{D}, 2.0 \mathrm{ml}$ solution $\mathrm{C}, 2.0 \mathrm{ml}$ glycerol (Sigma), $0.1 \mathrm{ml}$ of $0.4 \%(\mathrm{w} / \mathrm{v})$ bromophenol blue (BDH), $3.2 \mathrm{ml} \mathrm{d} / \mathrm{w}$ with $10 \%(v / v) \beta$-mercaptoethanol.

$1 \mathrm{x}$ running buffer was $6 \mathrm{~g}$ Tris $\mathrm{HCl}, 28.8 \mathrm{~g}$ glycine (Sigma) and $10 \mathrm{ml}$ solution $\mathrm{C}$ made up to $1 \mathrm{~L}$ with $\mathrm{d} / \mathrm{w}$.

Coomassie stain is $0.1 \%$ Coomassie blue (Sigma) in $10 \%$ (v/v) acetic acid (BDH), $50 \%(\mathrm{v} / \mathrm{v})$ methanol $(\mathrm{BDH})$ in $\mathrm{d} / \mathrm{w}$. Destaining was with $10 \%$ acetic acid, $5 \%$ methanol in $\mathrm{d} / \mathrm{w}$.

\section{Bacterial Media}

\section{L-Broth and L-Agar}


These were prepared by the Media Production Unit, ICRF. $10 \mathrm{~g}$ of Bacto-tryptone, $5 \mathrm{~g}$ of Bacto-yeast extract and $10 \mathrm{~g}$ of sodium chloride were dissolved in $11 \mathrm{~d} / \mathrm{w}$ and autoclaved. For L-agar $15 \mathrm{~g}$ of agar was added/1.

\section{SOC medium}

$20 \mathrm{~g}$ Bacto-tryptone, $5 \mathrm{~g}$ Bacto-yeast extract, $0.6 \mathrm{~g}$ sodium chloride, $0.2 \mathrm{~g}$ potassium chloride, $2 \mathrm{~g}$ magnesium chloride, $2.5 \mathrm{~g}$ magnesium sulphate and $3.6 \mathrm{~g} \mathrm{D}$-glucose were dissolved in $1 \mathrm{~L} \mathrm{~d} / \mathrm{w}$ and autoclaved.

\section{Antibiotics}

Ampicillin (Sigma) was added to L-broth or $\mathrm{L}$ agar plates to a final concentration of $60 \mu \mathrm{g} / \mathrm{ml}$.

\section{MOLECULAR BIOLOGY-GENERALPROCEDURES}

Unless otherwise stated methods used were as described in (Sambrook, et al. 1989).

\section{Isolation of total RNA}

Cell lysates were fractionated by centrifugation in caesium chloride solution. $5 \mathrm{ml}$ of cell lysate was layered on top of $8 \mathrm{ml}$ of $\mathrm{CsCl}_{2} / \mathrm{ETDA}$ solution in a Beckman $14 \times 95 \mathrm{~mm}$ Polyallomer ultracentrifuge tube. Tubes were spun at $32000 \mathrm{rpm}, 20^{\circ} \mathrm{C}$ for 21 hours in a Beckman ultracentrifuge using an SW40 swinging bucket rotor. The supernatant was removed, the pellet washed in $70 \%$ ethanol and the pellet dissolved in TE containing $0.1 \%$ SDS. The RNA was precipitated with sodium acetate and ethanol, the pellet washed with $70 \%$ ethanol and then air dried. The RNA was dissolved in DEPC treated water, and the quantity of RNA determined using a spectrophotometer (see below). RNA was stored at $-80^{\circ} \mathrm{C}$ in $70 \%$ ethanol, and recovered by precipitation after addition of sodium acetate.

\section{Isolation of mRNA.}

mRNA was isolated using oligo deoxythymidine (oligo dT) coupled magnetic beads, according to the manufacturers' instructions (oligo dT Dynabeads, Dynal).

\section{Phenol/chloroform extraction}


DNA was purified from protein in minipreps or cDNA library construction by phenol/chloroform extraction. 1 volume of phenol/chloroform/isoamyl alcohol equilibrated with Tris buffer, $\mathrm{pH} 8.0$ (25:24:1 by volume, Amresco) was mixed with 1 volume of DNA solution, vortexed thoroughly and centrifuged at $16000 \times \mathrm{xg}$ for 5 minutes at room temperature in a microfuge. 0.8 volumes of the upper aqueous phase were removed and placed in a fresh microcentrifuge tube. The remaining organic and aqueous phases were then back extracted: 0.8 volumes of TE was added to the organic layer, vortexed and centrifuged as before. 0.8 volumes of the upper phase was removed and added to the previously recovered aqueous phase.

\section{Precipitation of RNA}

$\mathrm{NaOAc}$ was added to a final concentration of $0.3 \mathrm{M}$ followed by 2 volumes of absolute ethanol $(\mathrm{BDH})$ at $-20^{\circ} \mathrm{C}$. The mixture was then vortexed thoroughly and centrifuged at $16000 \mathrm{xg}$ for 20 minutes at $4^{\circ} \mathrm{C}$ in a microfuge.

\section{Precipitation of DNA}

0.5 volumes of $\mathrm{NH}_{4} \mathrm{OAc}$ solution followed by 2 volumes of absolute ethanol (kept at $\left.-20^{\circ} \mathrm{C}, \mathrm{BDH}\right)$ were added to DNA in solution. If the concentration of DNA was less than $1 \mu \mathrm{g} / \mathrm{ml}, 1 \mu \mathrm{l}$ of glycogen $(20 \mathrm{mg} / \mathrm{ml}$, Boehringer Mannheim) was added as a carrier before the addition of ethanol. If the volume of ethanol was large 1 volume of isopropanol (at room temperature, BDH) was added in place of ethanol. The mixture was then vortexed and allowed to stand on dry ice for 10 minutes or placed at $-20^{\circ} \mathrm{C}$ for 30 minutes. The precipitate was centrifuged at $16000 \times g$ for 20 minutes in a microfuge at $4^{\circ} \mathrm{C}$ and the pellet washed in $0.5 \mathrm{ml} 70 \%$ ethanol (made up in DEPC treated water and kept at $-20^{\circ} \mathrm{C}$ ). The ethanol was removed and the pellet allowed to dry for 10 minutes at $37^{\circ} \mathrm{C}$.

\section{Quantification of nucleic acids in solution}

An aliquot of DNA or RNA in solution was placed in a quartz cuvette (Sigma) and the optical density at $260 \mathrm{~nm}$ and $280 \mathrm{~nm}\left(\mathrm{OD}_{260}\right.$ and $\mathrm{OD}_{280}$ respectively) determined in a spectrophotometer. The quantity of RNA or DNA was calculated from the $\mathrm{OD}_{260}$; in a cuvette with a $1 \mathrm{~cm}$ path length, an $\mathrm{OD}_{260}$ of 1 corresponds to $40 \mu \mathrm{g} / \mathrm{ml}$ RNA or $50 \mu \mathrm{g} / \mathrm{ml}$ of DNA. The purity of the solution was determined from the ratio of $\mathrm{OD}_{260}: \mathrm{OD}_{280}$ : the ratio for a pure solution of RNA is $1.8: 1$ and for a pure solution of DNA is $2.0: 1$. 


\section{Gel electrophoresis of DNA}

Gels were cast using $1 \%$ agarose in TBE or TAE buffer; ethidium bromide solution was added to $0.5 \mu \mathrm{g} / \mathrm{ml}$ (Sigma) before casting the gel. Samples were loaded in DNA loading buffer. Electrophoresis was performed in the same buffer as used to cast the gel. The DNA fragments were visualised using an ultraviolet transilluminator and photographed with a Polaroid camera. Molecular weight was determined by comparison with a 1kb DNA ladder (Gibco-BRL). Radiolabelled DNA and molecular weight markers were detected by autoradiography.

\section{Alkaline Gel electrophoresis of single stranded DNA}

A $1.4 \%$ agarose gel was cast in $30 \mathrm{mM}$ sodium chloride, $2 \mathrm{mM}$ EDTA and allowed to equilibrate with alkaline electrophoresis buffer ( $30 \mathrm{mM}$ sodium hydroxide, $2 \mathrm{mM}$ ETDA) for 2-3 hours. First strand cDNA and labelled molecular weight markers were loaded in alkaline loading buffer.

\section{Radioactive labelling of molecular weight markers}

DNA molecular weight markers were end labelled for use in autoradiographs of gels. $2.5 \mu \mathrm{l}$ of $1 \mathrm{~kb}$ DNA ladder (100ng/ $\mu \mathrm{l}$, Gibco BRL) was mixed with $1 \mu \mathrm{l} 10 \mathrm{x}$ Klenow buffer, $1 \mu$ l of dGTP, dATP and dTTP (1mM solution of each nucleotide, Pharmacia), $1 \mu$ l of $\mathrm{P}^{32}$ labelled dCTP (specific activity $3000 \mathrm{Ci} / \mathrm{mM}$, Amersham), $4 \mu \mathrm{l}$ of $\mathrm{d} / \mathrm{w}$ and $0.5 \mu \mathrm{l}$ Klenow fragment of DNA polymerase (Amersham), incubated for 5 minutes at room temperature and than placed on ice. $0.5 \mu l$ of labelled ladder was loaded with $10 \mu 11 \mathrm{x}$ sample buffer. The $1.6 \mathrm{~kb}$ fragment labels weakly compared with the other fragments under these conditions (see Figure 2.5).

\section{Autoradiography}

Preflashed Kodak XAR film was used: dried acrylamide gels were exposed at $-80^{\circ} \mathrm{C}$ and dried agarose gels at room temperature. Films were developed with a Fuji RGII developer.

\section{Miniprep of plasmid DNA}

$5 \mathrm{ml}$ of L-broth containing the appropriate antibiotic was inoculated with bacteria from a single colony and grown with shaking overnight at $37^{\circ} \mathrm{C}$. Bacteria from $1.5 \mathrm{ml}$ or $5 \mathrm{ml}$ cultures were pelleted by centrifugation at $1000 \mathrm{xg}$ for 10 minutes. 
The pellet was resuspended in 100 or $200 \mu \mathrm{l}$ of solution I and allowed to stand for 5 minutes at room temperature. 200 or $400 \mu$ l of solution II was then added, the tube inverted 4-6 times to gently mix the contents and placed on ice for 5 minutes. 150 or 300 $\mu$ l of solution III was then added, the tube was inverted 4-6 times and placed on ice for 5 minutes and then centrifuged at $16000 \mathrm{xg}$ for 10 minutes at $4^{\circ} \mathrm{C}$. 0.4 or $0.8 \mathrm{ml}$ of the supernatant was carefully removed avoiding the white precipitate. The DNA was then phenol/chloroform extracted, ethanol precipitated and the pellet washed in $70 \%$ ethanol, dried and dissolved in 20 or $40 \mu \mathrm{TE}$. $1 \mu \mathrm{l}$ of $10 \mathrm{mg} / \mathrm{ml}$ DNAse free RNAse A was added. 5 or $10 \mu$ l was used for each restriction digest.

\section{Construction of cDNA libraries}

\section{Cell Selection}

The rationale behind keratinocyte subpopulation selection is discussed in chapter 6 . Preconfluent cultured keratinocytes were plated on $150 \mathrm{~mm}$ diameter dishes coated with $100 \mu \mathrm{g} / \mu \mathrm{l}$ type IV collagen blocked with BSA. Cells were allowed to attach for 20 minutes, after which time the adherent cells (0-20 cells) were lysed in $2 \mathrm{ml}$ GIT solution. The lysate was scraped off the dish with a disposable cell scraper (Costar) and the dish rinsed with a further $3 \mathrm{ml}$ GIT solution which was added to the original GIT extract. The non adherent cells were transferred to another collagen coated dish for 1 hour. The cells that failed to attach were transferred to a third dish that had been coated with $100 \mu \mathrm{g} / \mathrm{ml}$ fibronectin and allowed to adhere for 3 hours. Cells that adhered $(60+$ cells) were lysed with GIT solution. As a control duplicate $100 \mathrm{~mm}$ diameter dishes coated were prepared, and an aliquot of 5000 of the keratinocytes allowed to adhere for the same time intervals as used for RNA isolation. The adherent cells in the $100 \mathrm{~mm}$ diameter dishes were counted, cultured for 2 weeks and their CFE scored as described above. mRNA was prepared from the cell lysates as above.

\section{In vitro translation to check mRNA quality}

To ensure that mRNA prepared as above was undegraded, $1 \mu \mathrm{g}$ of mRNA was translated in vitro using an Amersham reticulocyte lysate kit according to the Manufacturer's instructions. Incorporation of $35 \mathrm{~S}$ radiolabelled cysteine and methionine (specific activity $1000 \mathrm{Ci} / \mathrm{mmol}, \mathrm{ICN}$ ) into protein was measured over time by TCA precipitation of samples of the reaction mixture (Figure 2.2). 
After completion of the reaction the products were electrophoresed on a $7.5 \%$ polyacrylamide gel under reducing conditions (Lammeli 1970). A 7.5\% separating gel was prepared from $12.5 \mathrm{ml}$ solution $\mathrm{A}, 12.5 \mathrm{ml}$ solution $\mathrm{B}$ and $0.5 \mathrm{ml}$ solution $\mathrm{C}$ made up to $49.5 \mathrm{ml}$ in $\mathrm{d} / \mathrm{w}$. $0.5 \mathrm{ml}$ of a freshly prepared solution of $10 \%(\mathrm{w} / \mathrm{v})$ ammonium persulphate (Am Per) solution (Sigma) and $50 \mu \mathrm{l}, \mathrm{N}, \mathrm{N}^{\prime}, \mathrm{N}^{\prime}$ -tetramethylethylenediamine (TEMED, BioRad) were added and the gel poured immediately in a vertical gel tank (The Sturdier, Hoefer Scientific Instruments). The gel was overlaid with $0.1 \%$ SDS to ensure a flat surface on gelling. Once the separating gel had set the separating gel was poured above it: $3 \mathrm{ml}$ solution $\mathrm{A}, 0.2 \mathrm{ml}$ solution C, $5 \mathrm{ml}$ solution D, $11.6 \mathrm{ml} \mathrm{d} / \mathrm{w}, 0.2 \mathrm{ml}$ Am Per and $20 \mu \mathrm{l}$ TEMED were mixed and poured immediately. A comb was then inserted. Once the gel had set the gel tank was assembled and filled with running buffer.

Samples were loaded in sample buffer, with ${ }^{14} \mathrm{C}$ labelled protein molecular weight markers (Biorad). Electrophoresis was at a constant voltage of $40 \mathrm{~V}$ overnight, until the dye front reached the end of the gel. The gel was then stained with Coomassie stain for 30 minutes, destained for 2 hours, placed on Whatman 3MM filter paper and dried on a vacuum gel dryer (BioRad) at $80^{\circ} \mathrm{C}$ for 2 hours. Autoradiography was with preflashed XAR film (Kodak) at $-20^{\circ} \mathrm{C}$. Figure 2.2 shows the result with specific proteins produced from the keratinocyte mRNA.

\section{cDNA synthesis and ligation}

The Gibco-BRL Superscript system was used to construct directional cDNA libraries from keratinocyte mRNA. Three cDNA libraries were made; one from unfractionated cultured keratinocytes, another from keratinocytes that adhered to type IV collagen within 20 minutes and a third from keratinocytes that took over 60 minutes to adhere to type IV collagen. An outline of the method is shown in Figures 2.3 and 2.4. The Manufacturer's instructions were followed exactly except that phenol/chlorofrom extractions were back extracted with DEPC water and glycogen was used as a carrier for precipitation of DNA. The efficiency of first strand cDNA synthesis was $25-30 \%$. An aliquot of first strand CDNA was analysed by alkaline gel electrophoresis in a $1.4 \%$ agarose gel and samples of the gel chromatography column fractions were electrophoresed in a $1 \%$ agarose gel in TBE. The gels were dried on a BioRad gel dryer for 3-4 hours at $60^{\circ} \mathrm{C}$. Typical examples of these gels are shown in Figure 2.5. Double stranded cDNA was ligated into the plasmid pSport, see Figures 2.6 and 2.7. Ligation was carried out for 2 hours at room temperature or overnight at $16^{\circ} \mathrm{C}$. 


\section{Electroporation of ligated cDNA}

E coli strain SCS1 (sup E44; lac-;rec A1;end A1; gyr A96; thi-1; rel A1, (Hanahan 1983)) was streaked on LB agar plates and incubated overnight at $37^{\circ} \mathrm{C}$. Bacteria were eluted in $\mathrm{L}$ broth, placed in $100 \mathrm{ml} \mathrm{L}$ broth in a 11 flask and grown with shaking at $37^{\circ} \mathrm{C}$ to an optical density of 0.4 at $600 \mathrm{~nm}$ with a $1 \mathrm{~cm}$ pathlength. The bacteria were then chilled for 15 minutes in a salt water ice bath, centrifuged at $1000 \mathrm{xg}$ for 20 minutes at $4^{\circ} \mathrm{C}$, washed twice in ice cold $1 \mathrm{mM}$ HEPES pH 7.0 and once in distilled water, and then resuspended in distilled water (half the volume of the bacterial pellet) and placed on ice.

$1 \mu \mathrm{l}$ of ligated $\mathrm{cDNA}$ solution or $10 \mathrm{pg}$ control plasmid (Bluescript, gift from Christiana Ruhberg) were mixed with $40 \mu$ l of E.Coli on ice, placed in an ice cold electroporation cuvette $(0.2 \mathrm{~cm}$ electrode gap, BioRad) and electroporated using a BioRad Gene Pulser set at $25 \mu \mathrm{F}$ capacitance, $200 \mathrm{Ohms}$ resistance, and $2.5 \mathrm{KV}$ voltage. Time constants of 4.5 or 4.6 milliseconds were obtained. Bacteria were resuspended in $1 \mathrm{ml} \mathrm{SOC}$ medium prewarmed to $37^{\circ} \mathrm{C}$ and incubated at $37^{\circ} \mathrm{C}$ with vigorous aeration for 1 hour, and then spread on L-agar plates containing $60 \mu \mathrm{g} / \mathrm{ml}$ ampicillin (Sigma). $20 \mu \mathrm{l}$ of the ligated cDNA and control plasmid samples were spread on a $100 \mathrm{~mm}$ Petri dish (Sterilin) to determine the transformation efficiency: the rest of each sample was spread on a $22.5 \mathrm{~cm}$ square bioassay plate (Nunc), and incubated overnight at $37^{\circ} \mathrm{C}$. Transformation efficiencies of $9 \times 10^{8}$ to $5 \times 10^{9} / \mu \mathrm{g}$ plasmid DNA were obtained.

Each bioassay plate was eluted with $10 \mathrm{ml}$ L-broth, the eluate from 2 plates pooled (typically $2 \times 10^{5}$ independent transformants) and the bacteria recovered by centrifugation. Half the bacteria were then resuspended in 1x Hogness modified freezing medium (gift from S Meyer-Ewart, ICRF) and stored at $-80^{\circ} \mathrm{C}$. Plasmid DNA was prepared from the remaining E coli using Quiagen columns according to the Manufacturer's instructions. One Quiagen 500 column was used for each pool of $2 \times 10^{5}$ colonies, typically yielding $300 \mu \mathrm{g}$ of plasmid DNA. The plasmid DNA was dissolved in TE and stored at $-20^{\circ} \mathrm{C}$.

\section{Assessment of cDNA library quality}

Minipreps of plasmid DNA from 12-15 single colonies of the $x 1$ amplified libraries were prepared as described. The plasmids were then digested with the restriction endonucleases Not 1 (10 units/ $\mu \mathrm{l})$ and Sal 1 (10 units/ $\mu \mathrm{l})$ (Boehringer Mannheim) to 
release the cDNA insert. $10 \mu \mathrm{l}$ of RNAse treated miniprep was mixed with $2 \mu \mathrm{l}$ of high salt buffer (Boehringer Mannheim), $1 \mu$ l of each enzyme and $6 \mu l$ of $d / w$, and incubated for 2 hours at $37^{\circ} \mathrm{C}$. $10 \mu \mathrm{l}$ of the digest was electrophoresed in a $1 \%$ agarose gel with ethidium bromide in TBE and photographed with a Polaroid camera on an ultraviolet transilluminator. A typical gel is shown in Figure 2.5. The distance of migration of the inserts and the molecular markers was measured and insert size calculated from the formula

Distance migrated $=\mathrm{K} \times 1 /(\log$ (molecular weight)

where $\mathrm{K}$ is a constant determined from a regression analysis of the migration distances of the molecular weight markers using the computer program Cricket Graph III.

The mean insert size and number of independent transformants of each cDNA library is shown in Table 2.4. 
Table 2.4: cDNA libraries made with cultured keratinocytes

\begin{tabular}{|c|c|c|}
\hline Source of mRNA & Mean insert size (kb) & $\begin{array}{c}\text { Number of independent } \\
\text { transformants }\end{array}$ \\
\hline Unfractionated cells & 1.4 & $1.5 \times 10^{6}$ \\
\hline Rapidly adhering cells & 2.5 & $4 . \times 10^{5}$ \\
\hline Slowly adhering cells & 1.5 & $1.5 \times 10^{6}$ \\
\hline
\end{tabular}

\section{Preparing filters for screening.}

An aliquot of E Coli containing the rapidly adhering (0-20) cell library was thawed and the colony forming efficiency determined by spreading serial 10 fold dilutions of a $1 \mu \mathrm{l}$ aliquot onto $82 \mathrm{~mm}$ diameter Hybond $\mathrm{N}$ gridded filters (Amersham) incubated overnight at $37^{\circ} \mathrm{C}$ on $\mathrm{LB}$ agar plates with added ampicillin. The rest of the $\mathrm{E}$ coli were stored at $4^{\circ} \mathrm{C}$ overnight and then the volume needed to produce $10^{5}$ colonies spread over a $22 \times 22 \mathrm{~cm}$ Hybond $\mathrm{N}$ filter (Amersham) on LB agar with added ampicillin in a Nunc $22.5 \times 22.5 \mathrm{~cm}$ bioassay dish. The filter was incubated at $37^{\circ} \mathrm{C}$ overnight until the colonies were $1 \mathrm{~mm}$ in diameter. The filter was then placed colony side up on a sheet of Whatman 3MM filter paper which had been moistened with $\mathrm{L}$ broth. A second filter was placed directly on to the first filter, the filter paper folded over the filters and the filters placed between 2 perspex sheets on the floor. The filters were pressed together by standing on the upper perspex sheet. The replica filter was then marked at each corner by making holes with a 21 gauge needle, ensuring the holes went through to the master filter. The process was then repeated to produce a second replica filter. All three filters were then incubated for 2 hours at $37^{\circ} \mathrm{C}$. The master filter was then stored at $4^{\circ} \mathrm{C}$, while the replica filters were placed on filter paper soaked in denaturing solution for 7 minutes, and twice on to filter paper soaked in neutralising solution for 3 minutes. The filters were then washed in $2 \times S S C$, dried for 2 hours at $80^{\circ} \mathrm{C}$, and stored dry until use.

\section{Preparation of a subtracted probe}


The method used was that of Hampson et al (Hampson et al. 1992), and is discussed in Chapter 6. Single strand cDNA was reverse transcribed from mRNA from rapidly adhering cells. This was then hybridised in solution with RNA translated in vitro from a DNA template prepared from the cDNA library derived from slowly adhering keratinocytes described above. DNA/RNA hybrids were irreversibly cross linked using 2,5 diaziridinyl-1,4-benzoquinone (DZQ, Chemical Abstracts no. 52662-5, MW 100). Unique cDNA species were left in solution, radiolabelled and used to screen the cDNA library derived from rapidly adherent cells.

\section{Synthesis of cDNA from rapidly adhering cells}

mRNA was prepared from $50 \mu \mathrm{g}$ total RNA derived from rapidly adhering keratinocytes using oligo dT dynabeads, ethanol precipitated with glycogen and resuspended in $8 \mu \mathrm{l}$ DEPC treated water. $1 \mu \mathrm{g}$ of oligo dT $\left((\mathrm{T})_{18}\right.$, ICRF Oligonucleotide synthesis service) in $2 \mu \mathrm{l}$ DEPC water was added and the tube heated to $70^{\circ} \mathrm{C}$ for 10 minutes and then chilled on ice. The following were then added: $4 \mu$ l first strand buffer (Gibco BRL), $2 \mu$ l 0.1M DTT (Gibco BRL), $1 \mu \mathrm{l}$ $10 \mathrm{mM}$ dTNP mix and $1 \mu$ l of [ $\alpha-32 \mathrm{P}] \mathrm{dCTP}$, specific activity $3000 \mathrm{Ci} / \mathrm{mmol}$, diluted to $30 \mu \mathrm{Ci} / \mu \mathrm{l}$ (Amersham). After incubation at $37^{\circ} \mathrm{C}$ for 3 minutes $2 \mu \mathrm{l}$ of Superscript RT reverse transcriptase was added and incubation continued at $37^{\circ} \mathrm{C}$ for 1 hour. The final composition of the reaction was $50 \mathrm{mM}$ Tris-HCL pH 8.3,75mM KCL, $3 \mathrm{mM} \mathrm{MgCl}_{2}, 10 \mathrm{mM}$ DTT, $500 \mu \mathrm{M}$ of each of dATP, dTTP, dCTP, dGTP, $50 \mu \mathrm{g} / \mathrm{ml}$ oligodT primer, $100-200 \mu \mathrm{g} / \mathrm{ml} \mathrm{mRNA}$ and $20,000 \mathrm{U} / \mathrm{ml}$ Superscript RT.

The mRNA was than hydrolysed by addition of $20 \mu \mathrm{l} 1 \mathrm{M} \mathrm{NaOH}$ and incubation at $55^{\circ} \mathrm{C}$ for 15 minutes. The solution was neutralised by addition of $20 \mu \mathrm{l} 1 \mathrm{M} \mathrm{HCL}$. A $1.2 \mu \mathrm{l}$ aliquot was then withdrawn, spotted onto a nitrocellulose filter (Whatman), allowed to dry, counted in scintillant on a gamma counter and used to calculate the specific activity and reaction yield. The rest of the solution was passed down an autoclaved, pre spun Biospin 30 spin column (BioRad), used according to the Manufacturer's instructions. The eluate was counted in a gamma counter without scintillant, ethanol precipitated with glycogen as a carrier, allowed to dry and dissolved in $0.5 \mathrm{M} \mathrm{NaCl}, 25 \mathrm{mM}$ HEPES buffer $\mathrm{pH} 7.5,5 \mathrm{mM}$ EDTA, $1 \%$ SDS at 50ng cDNA/ $\mu \mathrm{l}$, for hybridisation with driver RNA (see Figure 6.1).

\section{Determination of first strand reaction yield}


The specific activity (SA) of dCTP in the first strand reaction is the activity of an aliquot (A) of the reaction divided by the quantity of dCTP in the sample.

Thus SA $(\mathrm{cpm} / \mathrm{pmol} \mathrm{dCTP})=\mathrm{A} / 200 \mathrm{pM} \mathrm{dCTP}$

The yield of the reaction can then be calculated from the activity of the eluate (X), assuming that on average dCTP represents one quarter of incorporated nucleotides and that $1 \mu \mathrm{g}$ of single stranded cDNA is equivalent to $3030 \mathrm{pmol} \mathrm{dNTP}$.

Thus, reaction yield $(\mu \mathrm{g})=(\mathrm{Xx} 4) /(\mathrm{SAx} 3030)$

Typically $1-2 \mu \mathrm{g}$ of single stranded (ss) cDNA was produced from $50 \mu \mathrm{g}$ of total RNA.

\section{Synthesis of RNA from non stem library}

Driver RNA was transcribed in vitro using SP6 RNA polymerase. The template was prepared by ethanol precipitation of $100 \mu \mathrm{g}$ plasmid DNA from 3 aliquots of the 1xamplified non stem cell cDNA library representing $10^{6}$ independent transformants. Each sample was digested overnight at $37^{\circ} \mathrm{C}$ with Sal 1 (Boehringer Mannheim), 100 units of enzyme were used in a total volume of $200 \mu l$. Proteinase $\mathrm{K}$ (Promega) was then added to $200 \mu \mathrm{g} / \mathrm{ml}$ and the samples incubated for 1 hour at $50^{\circ} \mathrm{C}$, phenol/chloroform extracted, ethanol precipitated and dissolved in DEPC water.

To produce RNA an Ambion Megascript SP6 kit was used according to the Manufacturer's instructions, typically yielding 20-40 $\mu \mathrm{g}$ of RNA per $20 \mu \mathrm{l}$ reaction. RNA was stored in ethanol solution at $-80^{\circ} \mathrm{C}$.

\section{Hybridisation and cross linking}

$20 \mu \mathrm{g}$ of driver RNA was precipitated and allowed to air dry. $10 \mu \mathrm{l}$ of stem cell ss cDNA solution (containing 500ng DNA) was added and the mixture incubated for 24-36 hours at $68^{\circ} \mathrm{C}$. The solution was then diluted with $40 \mu \mathrm{l}$ DEPC water and precipitated with $\mathrm{NH}_{4} \mathrm{OAc}$ and ethanol. The pellet was dissolved in $40 \mu \mathrm{l}$ Tris $\mathrm{HCl}$ pH 7.0 and $5 \mu 120 \mathrm{mM}$ ascorbic acid (Sigma) and $2.5 \mu \mathrm{l}$ fresh DMSO (Sigma) added. The mixture was incubated at $68^{\circ} \mathrm{C}$ for 3 minutes and then transferred to $45^{\circ} \mathrm{C}$. $1 \mu \mathrm{l}$ 
of a fresh $10 \mathrm{mM}$ solution of DZQ in DMSO was added. After 20 minutes the solution was chloroform extracted once, ethanol precipitated and the cross linking reaction repeated with a fresh $20 \mu \mathrm{g}$ of RNA.

\section{Labelling of probe}

$400 \mathrm{ng}$ of subtracted probe was labelled with $400 \mu \mathrm{Ci} \alpha^{32} \mathrm{P}$ dCTP (Amersham) using the Boehringer Mannheim random priming kit according to the Manufacturer's instructions, except that $6.5 \mathrm{U}$ of Sequenase II (USB) was substituted for the Klenow fragment and that the probe was not preboiled before labelling. The reaction was incubated for 20 minutes at room temperature, diluted to $100 \mu \mathrm{l}$ with STE buffer and passed through a Biospin 30 column. The probe was boiled for 5 minutes immediately before use.

\section{Screening of stem cell library}

The replica filters were wetted with $10 \mathrm{mls}$ of prehyb solution and placed colony side together in a Hybaid hybridisation cylinder, separated by $69 \mu \mathrm{m}$ nylon mesh $(R$ Cadish and Son's). A further $10 \mathrm{ml}$ of prehyb solution was added and the cylinder placed in a Hybaid hybridisation oven for 2 hours at $65^{\circ} \mathrm{C}$. The prehyb solution was then poured off, a fresh $10 \mathrm{ml}$ added and the boiled subtracted probe added to the cylinder, taking care that drops of undiluted probe did not contact the filters. The cylinder was then placed in the hybridisation oven at $65^{\circ} \mathrm{C}$ overnight. The probe solution was then poured off and the filters were washed in $1 \mathrm{xSSC}, 0.1 \%$ SDS at room temperature for 15 minutes, $1 \times$ SSC, $0.1 \%$ SDS at $65^{\circ} \mathrm{C}$ for 15 mins and three times in $0.1 \%$ SSC, $0.1 \%$ SDS at $65^{\circ} \mathrm{C}$ for 15 minutes each wash. Filters were then wrapped in Saran wrap (Dow Corning) and autoradiographed at $-80^{\circ} \mathrm{C}$. Positive clones were identified by marking the positions of the holes at the corners of the replica filters and using these to precisely align both X-ray films. A signal present at the same point on both filters was taken to be positive and was marked. Clones were picked from the master filter by aligning the filter and the marked $\mathrm{X}$ ray film on a light box. 50 clones were picked from a master filter with approximately $10^{5}$ colonies. Each clone was eluted into $750 \mu \mathrm{l}$ of $\mathrm{L}$ Broth with ampicillin and $0.5 \mu \mathrm{l}-1 \mu \mathrm{l}$ of this solution diluted in $200 \mu \mathrm{l}$ and spread over a $100 \mathrm{~mm}$ diameter LB agar plate with added ampicillin and incubated overnight at $37^{\circ} \mathrm{C}$ (see Figure 6.2). 
10 discrete colonies from each plate were picked, eluted into $0.2 \mathrm{ml} \mathrm{LB}$ with ampicillin, and grown for 2 hours at $37^{\circ} \mathrm{C}$. $20 \mu \mathrm{l}$ of each clone was spotted onto a gridded Hybond filter and grown for 2 hours; the remainder was stored at $4{ }^{\circ} \mathrm{C}$ in a 96 well plate (see Figure 6.3). The filter was then denatured and baked, screened with subtracted probe as before. Positive clones were identified by aligning the autoradiograph with the gridded filter. Miniprep DNA was cultured from each positive clone and digested with the restriction enzymes Pstl and Hinf 1 (New England Biolabs). The restriction fragments were examined by ethidium bromide /agarose gel electrophoresis, to ensure the identity of the positive clones from each isolate. The secondary screen positives await use as probes in Northern blotting of RNA from keratinocyte subpopulations, to confirm that they are differentially expressed.

\section{STATISTICAL METHODS}

The following tests of statistical significance were used applied as described by Altmann and carried out using the computer programs Excel 4.0 and Statview SE: $\chi^{2}$ test for paired proportions; standard error of a proportion; Mann Witney $U$ test and Student's t-test.

In addition 2 tests were carried out by D Altmann, head statistician, ICRF. Analysis of covariance was used to examine the probability of a log-linear relationship between CFE and $\alpha_{2}$ and $\beta_{1}$ integrin subunit expression. The $p$ value is the probability that the observed data would have arisen by chance (see Figure 2.8). Analysis of multiple, small paired proportions from histone in situ hybridisation experiments (see chapter 4 ) was performed by D Altmann using the method of Greenland and Robbins. 
FIGURE 2.1: Method for grafting cultured human keratinocytes into nude mice

A confluent sheet of keratinocytes was inserted basal side uppermost as shown, resting on 2 sheets of Silastic, under a flap raised on the dorsum of the mouse. Flaps were secured with surgical clips. Figure adapted from Barrandon et al (1988). 


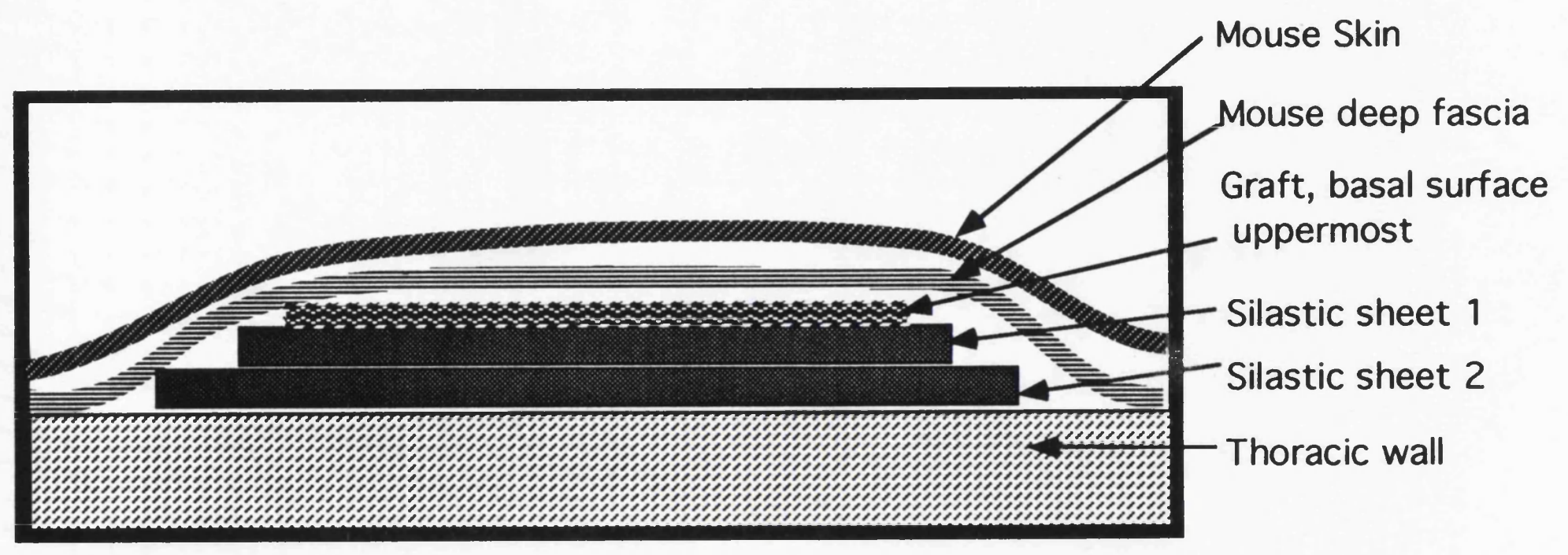




\title{
FIGURE 2.2: In vitro translation of RNA isolated from keratinocytes
}

mRNA from keratinocytes was translated in vitro using reticulocyte lysate.

\author{
A) Incorporation of ${ }^{35} \mathrm{~S}$ labelled cysteine and methionine into protein products of in \\ vitro translation.
}

The $\mathrm{x}$ axis shows time of reaction in minutes. The $\mathrm{y}$ axis shows TCA precipitable counts per minute (CPM) per microgram of RNA added to the lysate.

Open squares: no added RNA (negative control)

Filled diamonds: keratinocyte mRNA

Open circles: Tobacco Mosaic Virus (TMV)RNA (positive control).

B) Autoradiograph of polyacylamide gel electrophoresis of products of in vitro translation.

Products were electrophoresed under reducing conditions in a 7.5\% polyacrylamide gel. Lanes were loaded as follows:

Lane M: C14 labelled molecular weight markers with molecular weights as shown.

Lane 1: no added RNA.

Lane 2: TMV RNA.

Lane 3: Keratinocyte mRNA. 
A

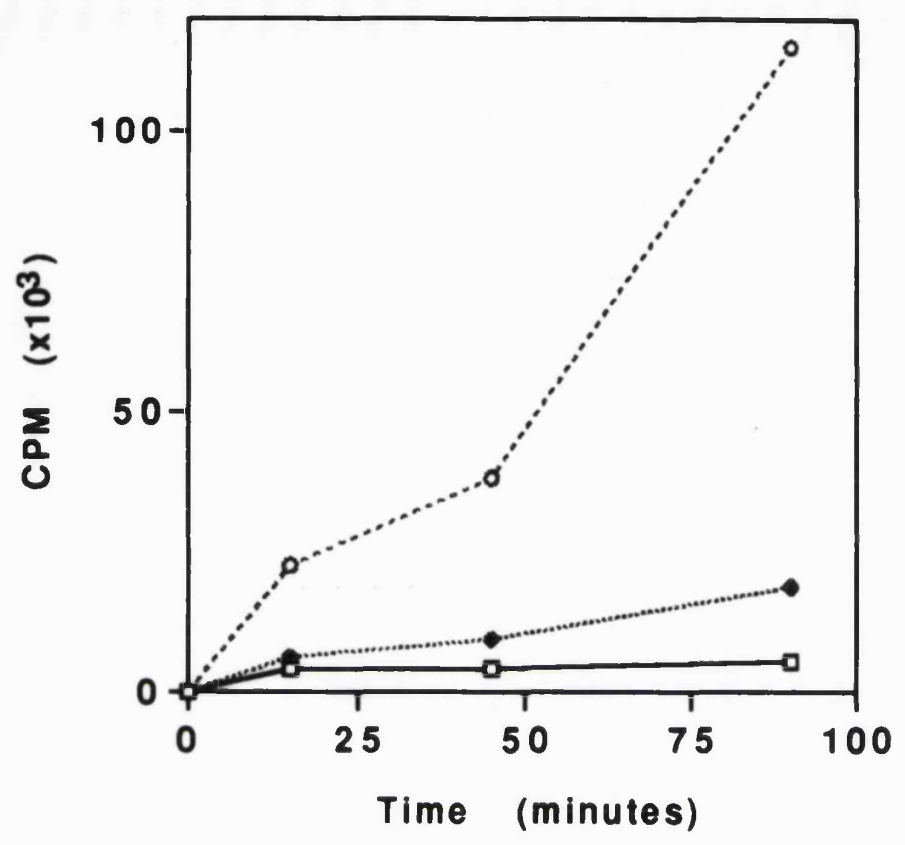

B

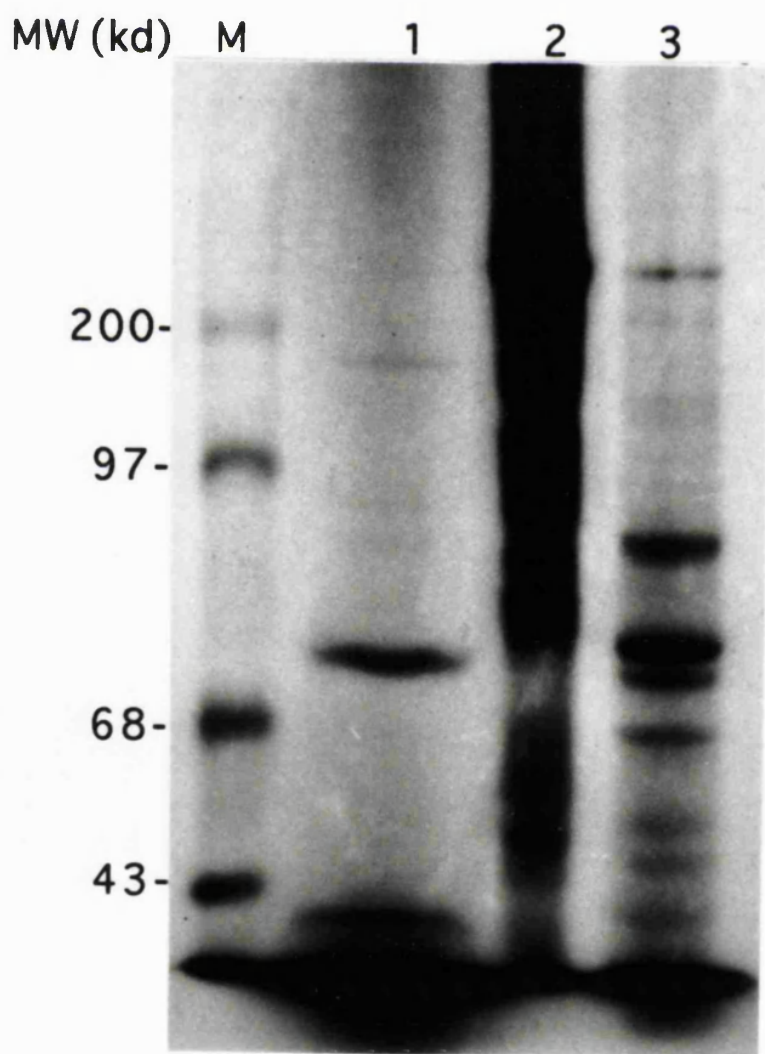


FIGURE 2.3: Outline of method for construction of oligo dT primed directional cDNA libraries.

See Figure 2.4 for detailed protocol. Figure reproduced from Manufacturer's handbook (Gibco BRL). 

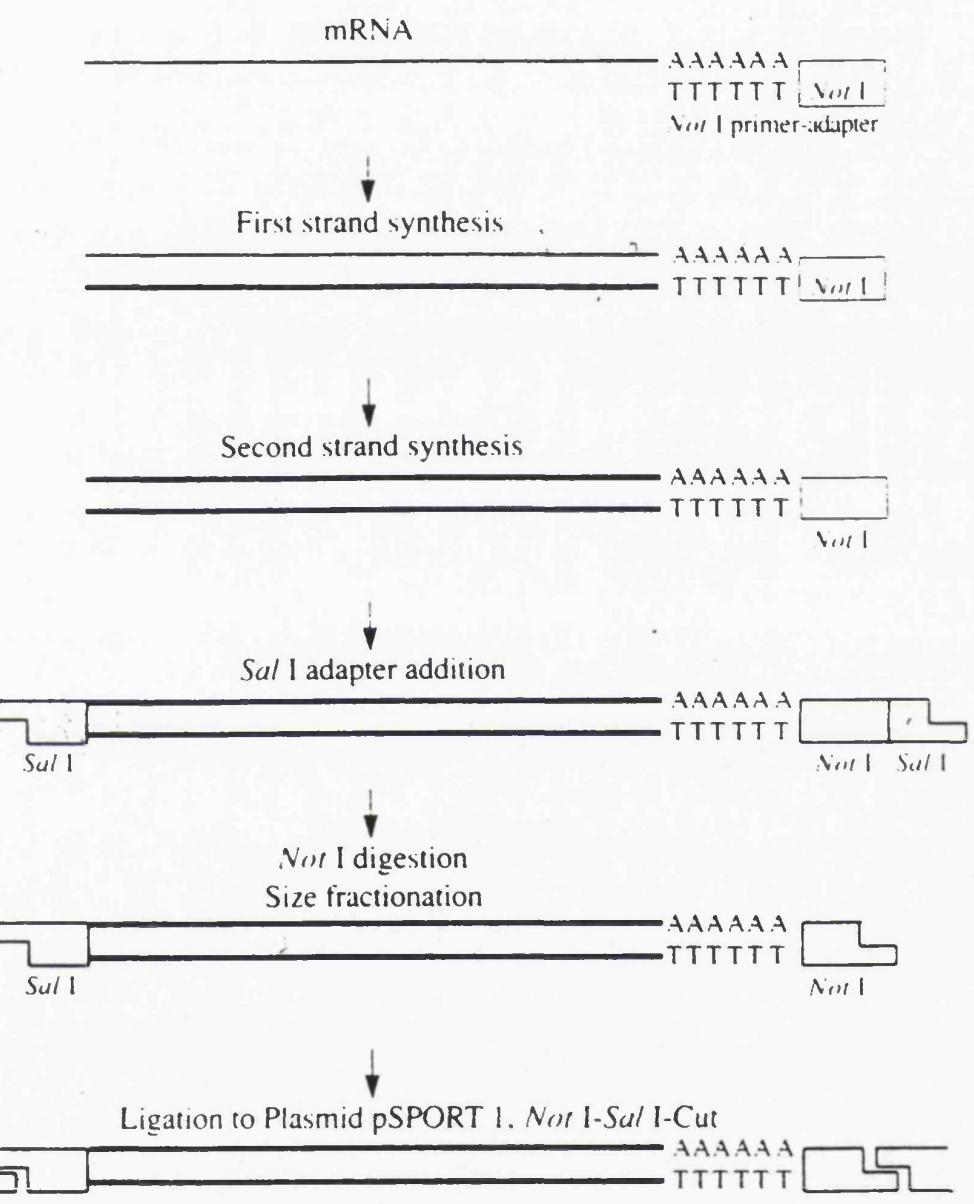

cDNA ready for transformation 
FIGURE 2.4: Method of cDNA library construction

Reactions used to synthesise a directional cDNA library are shown. The procedure was completed within 3 days to minimise the effects of radioactivity on the cDNA.

Notes

1 The Not 1 primer adapter sequence was-

5'-pGACTAGTTCTAGATCGCGAGCGGCCGCCC(T) 15 -3'

Not1

2 Superscript RT is a modified form of the Moloney mouse murine leukaemia virus that lacks RNase $\mathrm{H}$ activity and so does not hydrolyse RNA-primer hybrids.

3 ds - double stranded

4 The Sal 1 adapter sequence was-

5'-TCGACCCACGCGTCCG -3'

3'- GGGIGCGCAGGCp-5'

Sal1 Mlu 1 


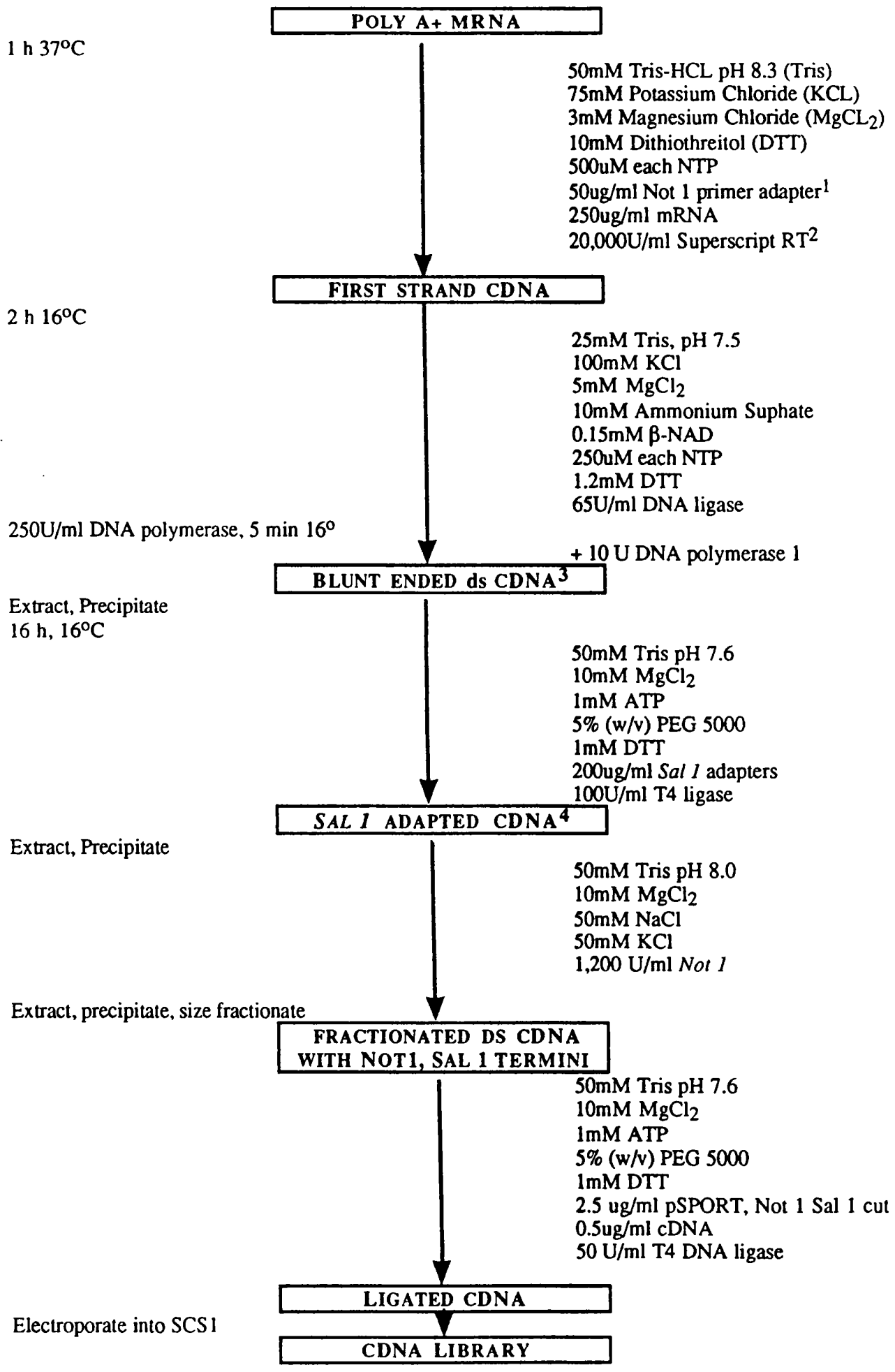


FIGURE 2.5: cDNA synthesis, size fractionation and ligation into plasmid.

A) Agarose gel electrophoresis of first strand cDNA.

An aliquot of first strand cDNA was ethanol precipitated and then run on a $1.4 \%$ alkaline agarose gel (Lane 1).

Molecular weight was determined with $\alpha$ 32P dCTP labelled $1 \mathrm{~kb}$ DNA ladder (BioRad, lane M).

B) Size fractionation of cDNA.

Consecutive fractions from a Sephacryl S-500 column were ethanol precipitated, from the first fraction with radioactivity above background (Lane 1) to the fraction at which the total column run off was $550 \mu 1$ (Lane 7). $10 \%$ of each fraction was electrophoresed on a $1 \%$ agarose gel with a $32 \mathrm{P}$ labelled $1 \mathrm{~kb}$ DNA ladder $(\mathrm{M})$.

C) Ethidium bromide stained DNA gel showing restriction digests of plasmid DNA from $x 1$ amplified keratinocyte cDNA library.

Plasmid DNA was extracted from randomly picked colonies of a x1 cDNA library by alkaline lysis miniprep, and then digested with Not1 and Sal1 restriction endonucleases (Boehringer Mannheim), electrophoresed in a 1\% agarose gel containing $0.5 \mu \mathrm{g} / \mathrm{ml}$ ethidium bromide, and the gel viewed on an ultraviolet transilluminator. A $1 \mathrm{~kb}$ DNA ladder was run in lane $\mathrm{M}$, other lanes contain plasmid (4.2kb upper band) and the cDNA insert (lower band). 


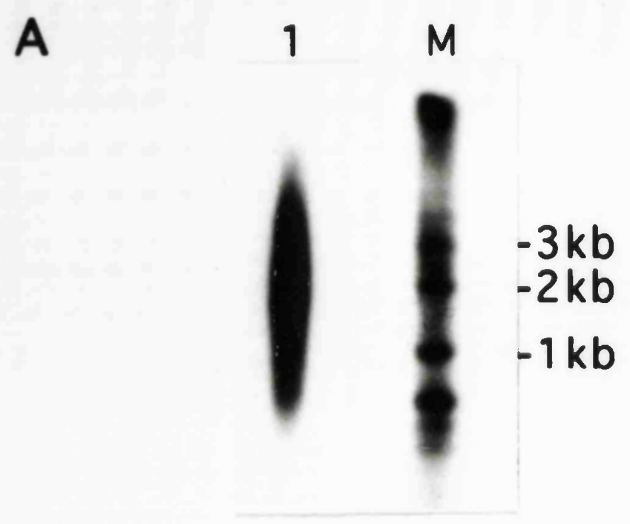

B

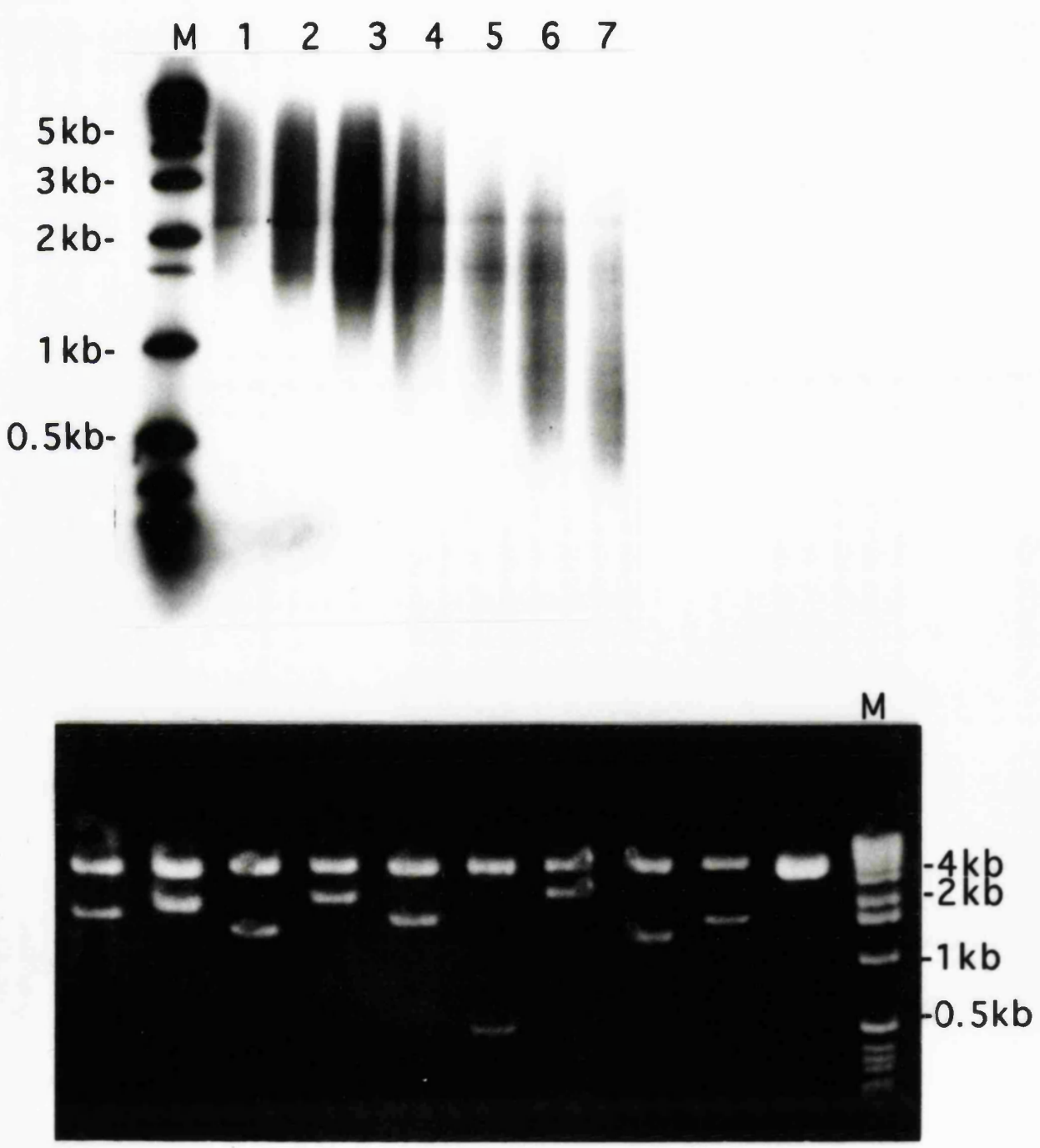




\section{FIGURE 2.6: Plasmid Map of pSport 1 (Gibco-BRL)}

Figure reproduced from Manufacturer's handbook (Gibco BRL).

The features of this 4084 base pair plasmid are-

Replicon: colE1

Antibiotic resistance: Ampicillin

lac operon elements: lacI, lac $\mathrm{P}$, lac $\mathrm{O}, \operatorname{lac} \mathrm{Z}$ ( $\alpha$-peptide fragment)

These elements allow transcription of cDNA inserts by inducing the lac promoter (lacP) by addition of $1 \mathrm{mM}$ isopropylthio- $\beta$-galactoside (IPTG) to the growth media. In the abscence of IPTG transcription of inserts is repressed by the lac repressor gene (lacI)

SP6 and T7 RNA polymerase promoters

These allow synthesis of RNA in vitro from either cDNA strand.

\section{Bacteriophage $\mathbf{f 1}$ intergenic region}

This can be used to synthesise the single stranded form of the plasmid. 


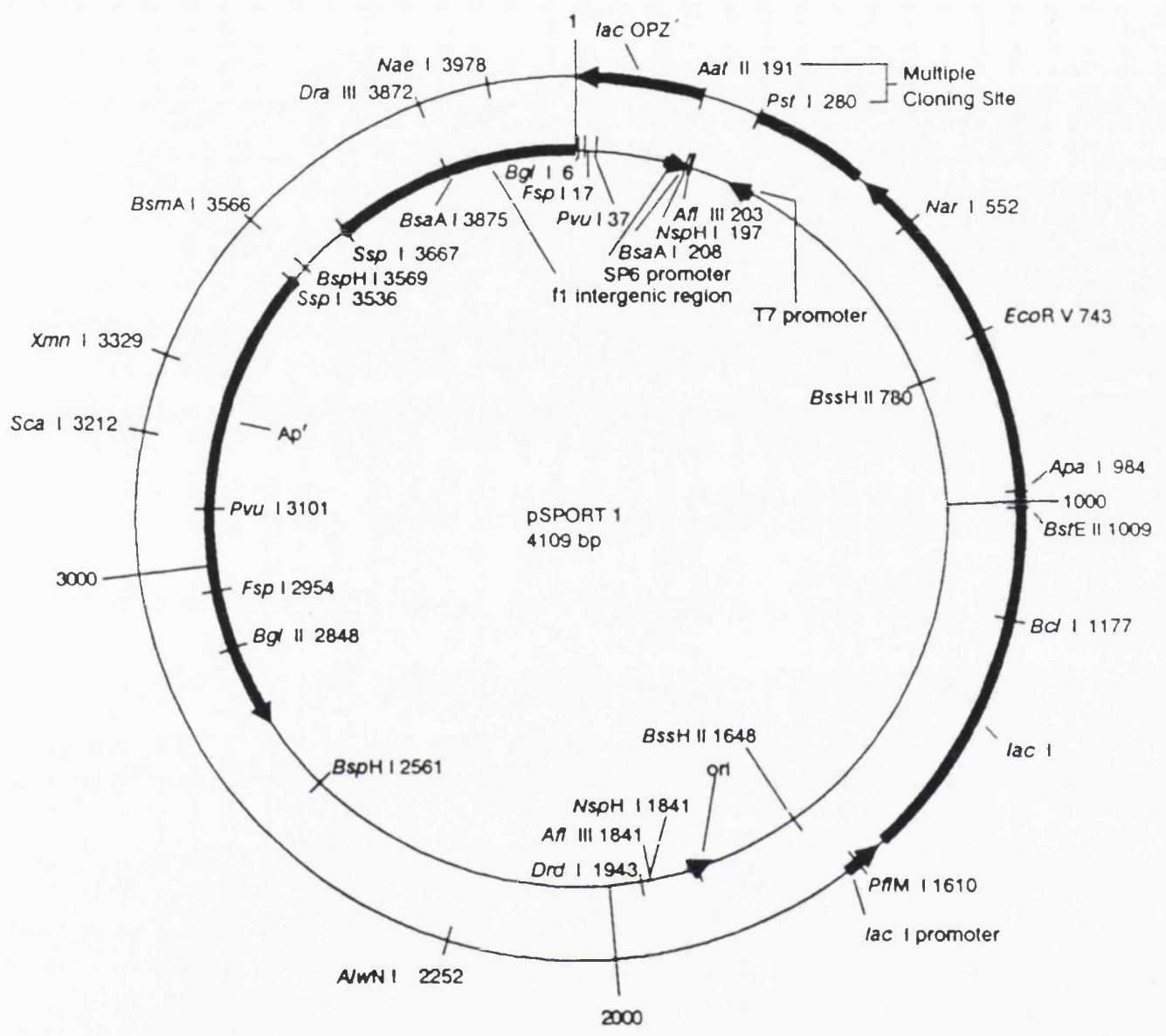


FIGURE 2.7: The multiple cloning site of pSport

Figure reproduced from Manufacturer's handbook (Gibco BRL). 


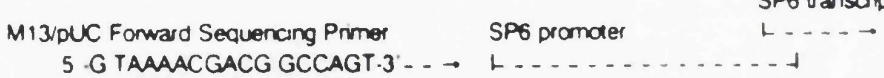

5 CCCAGT CACGACGITG TAAAACGACG GCCAGTGAAT TGAATTIAGG TGACACTATA GAMGAGCTAT GACGTCGCAT GCACGCGTAC GTAAGCTGG ATCCTCTAGA

5 CCCAGT CACGACGTTG TAAAACG-3

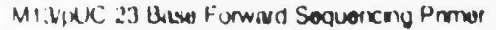

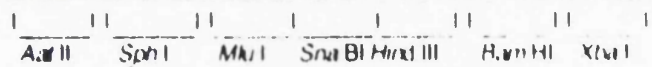$$
\text { Sor1 }
$$

21 bases removed trom

NaI. Sall cur vector

7 promoter

a-pepode stan

GCGGCCGCCG ACTAGTGAGC TCGTCGACCC GGg AATTCCG GACCGGTACC TGCAGGCGTA CCAGCTTCC CTATAGTGAG TCGTATTAGA GCTTGGCGTA ATCATGGTCA TAGCTGITC.3

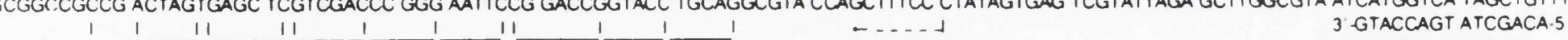

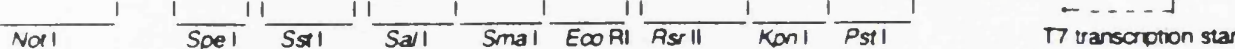

JT3 Sequenco Pna

xma III

Qsp MII 
FIGURE 2.8: Analysis of covariance of the relationship between integrin expression and CFE

Data from 3 FACS sorts of basal cells stained with HAS6-FITC antibody against the $\alpha_{2}$ integrin subunit are shown. The mean fluorescence of the sorted cells is in arbitrary units on a log scale on the $\mathrm{x}$ axis and the CFE each group of sorted cells on the y axis.

Analysis of covariance gives the probability that the observed relationship arose by chance. This is $<0.0001$ (calculated by D Altman, head statistician, ICRF). 


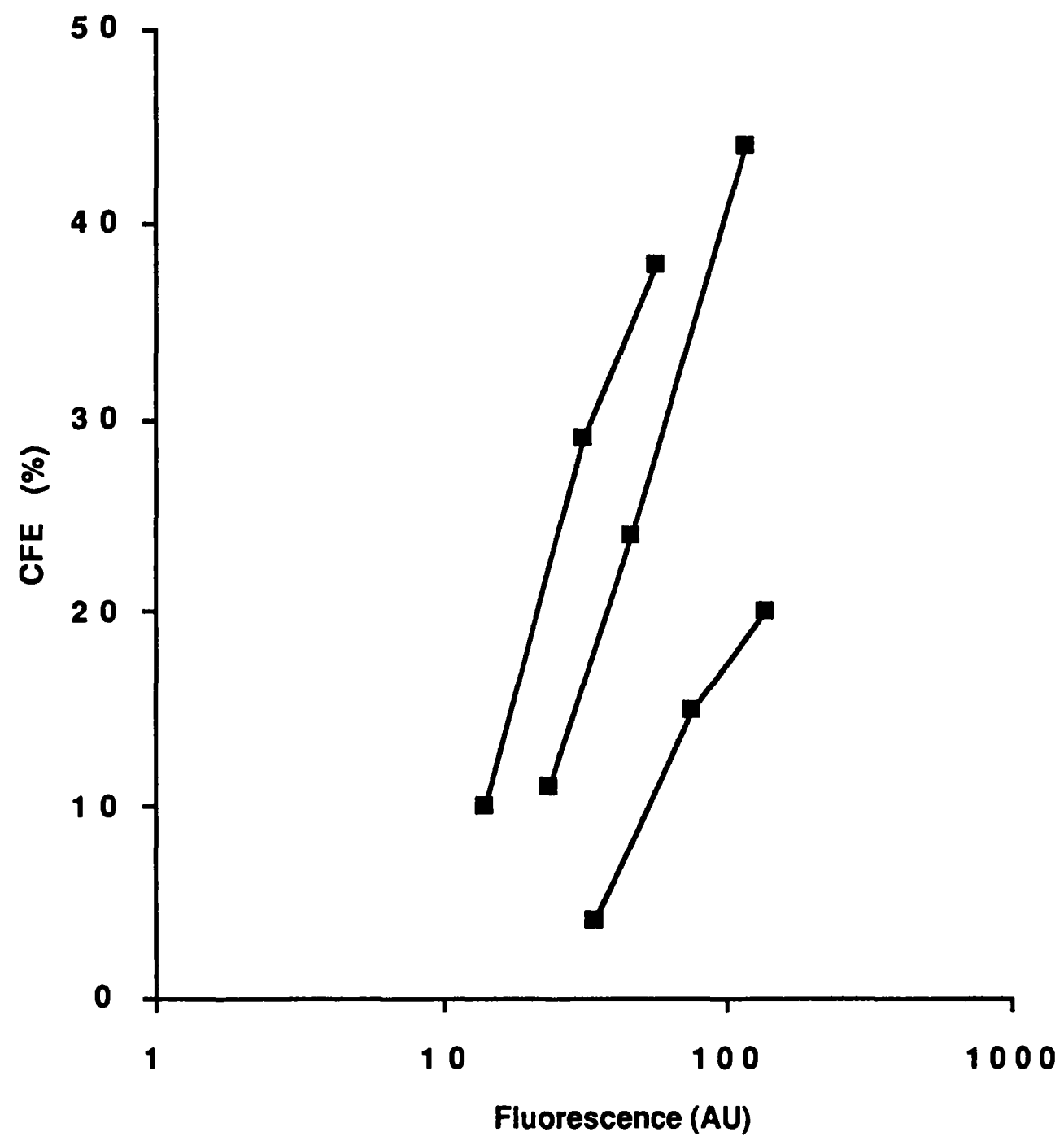




\section{CHA P T E R 3 \\ EPIDERMAL STEM CELLS IN VITRO}

\section{INTRODUCTION}

Differentiation of basal keratinocytes is accompanied by loss of adhesion to extracellular matrix (ECM) as discussed in Chapter 1. It seemed possible that the least differentiated keratinocytes, the stem cells, might be the most adhesive to ECM. I set out to investigate if there was a link between the proliferative potential of basal keratinocytes and their adhesiveness to extracellular matrix which could be used to isolate human epidermal stem cells.

A convenient source of keratinocytes was epidermis cultured in vitro. I decided to use the culture method of Rheinwald and Green (Rheinwald and Green 1975; Rheinwald 1989). The Rheinwald and Green (RG) model offered several advantages. Firstly, keratinocyte proliferation had been studied extensively and the cultures shown to contain clonogenic cells of different types ((Barrandon and Green 1987b), and see discussion in Chapter 1). The adhesive characteristics of RG keratinocytes were known. Both the integrin ECM receptors present on basal cells and their ligands had been defined (Adams and Watt 1991). Finally there was evidence from clinical studies that epidermal stem cells persisted within this culture system. When sheets of RG keratinocytes were grafted onto patients they give rise to a near normal epidermis that persists for many years (Gallico III et al. 1984; Compton et al. 1989; Compton 1992).

The first problem was how to define a stem cell. Clonogenicity is the characteristic of stem cells that is simplest to assay in culture. I opted for a working definition of a stem cell based on clonogenicity: a stem cell was a cell that founded a keratinocyte colony visible under a dissecting microscope after 14 days in culture. In practice this means a colony of at least 32 cells, though most colonies were much larger, containing over 5000 cells.

I used two methods to fractionate basal keratinocytes on the basis of their adhesiveness to ECM. The first was to sort cells according to the level of surface expression of integrin ECM receptors using flow cytometry. The other approach was 
to exploit the fact that cultured keratinocytes adhere progressively to ECM proteins over 3 hours (Adams and Watt 1991). I reasoned that the rapidly adhering cells may have different properties from those that adhered more slowly. Keratinocytes fractionated by either method were then cultured and their colony forming efficiency (CFE) calculated by dividing the number of colonies containing at least 32 cells by the number of cells that attached. As a control unfractionated basal cells were plated out and the control CFE calculated by dividing the number of colonies by the number of basal cells plated.

\section{RESULTS}

\section{Flow cytometry of cultured keratinocytes}

\section{Isolation of basal cells}

Flow cytometric cell sorting (FACS) offered a means to sort viable cells on the basis of integrin expression, but the cells had to be in a single cell suspension. Keratinocyte cultures contain both basal cells and suprabasal cells. It was essential to be able to identify basal and suprabasal cells in suspension in order to be able to purify the basal cells. A convenient marker of suprabasal cells in culture is the cytoplasmic protein involucrin, which is expressed in all suprabasal cells (Banks Schlegel and Green 1981). Basal cells were identified by their size and their lack of involucrin expression - cells under 14 microns in diameter are involucrin negative (Watt and Green 1981).

Work done by $\mathrm{C}$ Linge at King's College, London (unpublished) suggested that suprabasal cells differ in their light scattering characteristics from basal cells. I examined the forward and side light scatter (FSC and SSC respectively) of single cell suspension of cultured keratinocytes (Figure 3.1a). FSC is the laser light scattered parallel to the laser beam, and is related cell size (Mullaney and Dean 1970; Salzman et al. 1979; Kerker 1983). SSC is the laser light scattered at $90^{\circ}$ to the laser beam, and is a function of nuclear size and shape (Benson et al. 1984) and the arrangement of cytoplasmic proteins, such as the degree of actin polymerisation (Sklar et al. 1985). Despite the large number of factors that affect SSC, for a given cell type it is highly reproducible and is a useful parameter for cell sorting (Salzman et al. 1975; Ward et al. 1986; Spangrude et al. 1988). Dead cells were gated out using propidium iodide (Krishan 1975), viability ranged from $85-98 \%$. 
2 populations of keratinocytes which differed in side light scatter were seen; group A with low side light scatter, and group B with higher forward and side light scatter. This pattern is highly reproducible and has been seen in each of over 50 experiments. Cells from these regions were sorted into dishes for assessing their CFE and air dried on to coverslips and stained for involucrin. Table 3.1 shows the results. Over $95 \%$ of the cells in region A were involucrin-negative and therefore basal cells. Region A contained almost all of the clonogenic cells. Over $50 \%$ of cells in region B were involucrin-positive suprabasal cells, the others were non clonogenic basal cells.

\section{Integrin expression in keratinocytes}

I then stained suspensions of keratinocytes with antibodies to most of the major integrin subunits expressed by keratinocytes $\left(\alpha_{2}, \alpha_{3}\right.$, and $\alpha_{5}$, and their partner $\beta_{1}$, and $\alpha_{6}$, which partners $\beta_{4}$ ), and analysed them by FACS. In each case when the basal cells in region A were examined there was a single peak of fluorescence (Figure 3.1B, and data not shown). In contrast the fluorescence histogram of unfractionated keratinocytes contained a second peak or shoulder of cells with lower surface integrin levels. When keratinocytes are double labelled for integrin and with another marker of suprabasal cells, peanut agglutinin (PNA), (Figures 3.2, 3.3, 3.4, Watt and Jones 1992; Watt and Jones 1993; Jones and Watt 1994), it can be seen that the left hand peak represents suprabasal cells. Furthermore when keratinocytes are induced to differentiate in suspension culture the number of integrin dull cells rises in parallel with the increase in the number of suprabasal cells in the population (Figure 3.5).

\section{Colony forming efficiency (CFE) of basal cells fractionated on the basis of integrin expression}

Basal keratinocytes in region A were fractionated by FACS into 3 or 4 groups on the basis of integrin expression and replated onto feeder cells to determine their CFE. The first subunit examined was $\alpha_{2}$. Basal cells were sorted into three categories: the $20 \%$ of cells with the highest level of $\alpha_{2}$ fluorescence (80-100; Figure 3.1B) the mid $40 \%$ of the population (30-70; Figure 3.1B) and the 20\% of cells with least $\alpha_{2}$ fluorescence (0-20; Figure 3.1B). All the cells within region A were sorted as a control group. After 14 days the number of colonies was scored. There was a 4 fold difference in CFE between the groups with highest and lowest levels of $\alpha_{2}$ fluorescence (Figure 3.6A, Figure 3.7A) -these groups differed 3 fold in their mean $\alpha_{2}$ fluorescence (Figure 3.1B). 
The flow cytometer measures the total fluorescence of a cell rather than the fluorescence per unit area. Thus a large cell with a low density of integrins per unit area on the cell surface could have the same fluorescence as a small cell with a high density of surface integrins. To determine if the differences in fluorescence of basal keratinocytes reflected differences in cell size, the diameter of cells in each fluorescence category was measured (Table 3.2). There was less than $1 \mu \mathrm{m}$ difference in the mean diameter of the high and low fluorescence groups but a 3 fold difference in their average relative fluorescence intensity. Colony forming efficiency was thus related to receptor density and not to cell size. When CFE was plotted directly against the logarithm of fluorescence a linear relationship was seen $(p<0.0001$ by an analysis of covariance using data from 3 experiments, performed by D Altman, see Figure 2.8).

Although the number of colonies varied with the level of surface integrin the types of colonies formed by integrin-bright basal cells did not differ from those formed by integrin-dull basal cells. Large colonies (over $2 \mathrm{~mm}$ diameter, containing over 5000 cells (Barrandon and Green 1987b)) and small colonies (less than $2 \mathrm{~mm}$ diameter) were found in all sort groups (Figure 3.7).

To see whether it was possible to enrich further for colony forming cells by sorting for other integrin subunits I performed three colour labelling experiments where keratinocytes were stained simultaneously with antibodies to the $\alpha_{2}, \alpha_{3}$ and $\alpha_{5}$ integrin subunits. The levels of all three subunits varied together in the basal cell population (Figure 3.6, d-f): cells with high surface expression of $\alpha_{2}$ also had high levels of $\alpha_{3}$ and $\alpha_{5}$. When cells with the highest surface levels of all 3 subunits were sorted we obtained no significant enrichment in CFE compared with that obtained when cells were sorted on the basis of $\alpha_{2}$ expression alone ( $p>0.10$ by $\chi 2$ test, Figure 3.8).

These results suggested that if cells were sorted on the basis of $\beta_{1}$ (the $\beta$ subunit common to $\alpha_{2}, \alpha_{3}$ and $\alpha_{5}$ ) expression the cells with the highest levels of $\beta_{1}$ would have the highest CFE. We found that this was the case (Figure 3.6). The same log linear relationship was seen between $\beta_{1}$ fluorescence and $C F E$ as had been seen with $\alpha_{2}$ ( $p<0.0001$ by analysis of covariance performed by D Altman using data from 4 experiments). The relative enrichment for colony forming cells was the same as that obtained by sorting on the basis of $\alpha_{2}$ expression. 
In contrast to the results obtained with the $\beta_{1}$ integrins there was no significant correlation between the level of $\alpha_{6}$ fluorescence and CFE (Figure 3.6c).

\section{CFE of keratinocytes that adhere most rapidly to extracellular matrix proteins}

Next we investigated whether there was a relationship between the rate at which keratinocytes attached to ECM proteins and their CFE. I chose proteins that had been previously shown to be integrin ligands in keratinocytes and used them at coating concentrations known to give maximal adhesion (Adams and Watt 1991). I also used a preparation of keratinocyte extracellular matrix (K-ECM) rich in laminin 5 (Rousselle, Lunstrum et al. 1991). Unfractionated keratinocytes were plated onto type IV collagen $(100 \mu \mathrm{g} / \mathrm{ml})$, laminin $(25 \mu \mathrm{g} / \mathrm{ml})$, fibronectin $(10$ or $100 \mu \mathrm{g} / \mathrm{ml})$ or $\mathrm{K}$ ECM. At different times the cells were detached with trypsin/EDTA, counted and plated onto feeders. Controls were plated directly onto feeders with no preselection. After 2 weeks of culture all colonies containing 32 or more cells were scored.

The results are illustrated in Figure 3.9. Cells that adhered most rapidly to type IV collagen, fibronectin and K-ECM had a higher CFE than controls. The maximum enrichment obtained was 5.5 fold in cells which adhered to type IV collagen within 20 min ( $10 \%$ of total basal cell population in the experiment shown). Adhesion to fibronectin was very rapid at both coating concentrations tested: cells adhering to fibronectin in 5 minutes ( $28 \%$ of total basal cell population in the experiment shown) showed a 2 fold increase in CFE over controls and it was not possible to recover the cells more quickly. Cells adhering to K-ECM (16\% of total basal cell population in the experiment shown) within 10 minutes were enriched 4 fold for CFE. In contrast the cells which adhered most rapidly to laminin 1 did not have the greatest CFE: the maximum enrichment seen with laminin was never more than 2 fold and occurred after $30 \mathrm{~min}$ (when 13\% of the total basal cell population had adhered in the experiment shown). The proportion of basal cells that attached at the shortest timepoints varied between experiments but the increase in CFE relative to the control

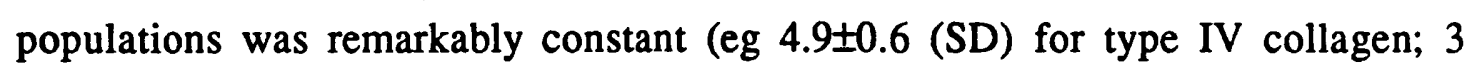
experiments). As illustrated in Figure $3.9 \mathrm{~B}$ the percentage of basal cells capable of forming colonies did not vary with time of plating on collagen. However the percentage of basal cells that attached and did not form colonies increased at later time points. 
These results could be explained in two ways. Firstly, the cells that adhered most rapidly to collagen, fibronectin and K-ECM represented a distinct subpopulation of basal cells. Alternatively the rate of attachment of individual cells was random, and either rapid adhesion provided a stimulus for proliferation, or slow adhesion resulting in differentiation and the loss of colony forming ability.

To distinguish between these we examined the surface integrin levels of cells that adhered most rapidly to collagen compared with unfractionated basal cells. The modal $\alpha_{2}$ integrin subunit fluorescence of the cells that adhered within 20 minutes was greater than that of the unfractionated basal cell population (Figure $3.9 \mathrm{c}$ ). Thus the rate at which cells attach was not random and the rapidly adhering cells represented the basal cell subpopulation with highest integrin expression. Further, when unfractionated keratinocytes were placed in suspension culture for intervals between 0 and 5 hours, the CFE showed no decrease until 2 hours in suspension (Figure 3.10) As adhesion of keratinocytes is almost complete by 2 hours (Adams and Watt 1991) differences in the rate of attachment do not in themselves account for the observed differences in CFE. These results are consistent with the observation that cells with the highest levels of $\beta_{1}$ integrins had the highest CFE in the cell sorting experiments (Figure 3.6 a).

I concluded that the cells with the highest CFE adhered most rapidly to several ECM proteins and had the highest level of $\beta_{1}$ integrins. Adhesion to type IV collagen was used in further experiments because it gave the greatest enrichment for colony forming cells in a convenient length of time ( 20 minutes).

For the adhesion experiments described above, cells were trypsinised twice: once prior to adhesion to ECM and once prior to plating onto feeder cells. I investigated the maximum CFE that could be achieved if the cells were treated more gently. Preconfluent, second passage cells were plated on to tissue culture plastic dishes that had been coated with type IV collagen and after 20 minutes nonadherent cells were washed off. Feeders were then added to some of the dishes and the cells cultured for 14 days; the other dishes were fixed and the number of adherent cells was counted. Under these conditions I obtained CFEs of up to $91.5 \%( \pm 2.8 \%, \mathrm{SEM})$ when the CFE of unfractionated basal cells plated directly onto feeders was $19.5 \%$ ( \pm $2.0 \%$, SEM). This represented a 4.7 fold enrichment in colony forming ability. $87 \%$ of the colonies founded by the rapidly adhering cells were large ( $>2 \mathrm{~mm}$ diameter, 
containing over 5000 cells) and all contained both basal, involucrin-negative, and suprabasal, involucrin-positive cells.

Having been able to isolate a population of basal cells that had a very high CFE, I went on to investigate if these cells possessed other predicted characteristics of epidermal stem cells.

\section{Differentiation and self renewal of rapidly adherent cells}

If dishes containing colonies founded by rapidly adhering cells were harvested and the cells plated on to type IV collagen, the population contained both rapidly and slowly adhering basal cells and differentiated non adherent suprabasal cells, in approximately the same proportions as in unselected keratinocyte cultures (see Figure 3.11). When analysed by flow cytometry the profile of integrin expression was identical to that of unselected keratinocytes. Thus rapidly adhering cells could both self renew and generate differentiated keratinocytes.

\section{Suspension culture of cells with high colony forming efficiency}

When studying 12-0-tetradecanoylphorbol-13-acetate (TPA) induced differentiation of cultured keratinocytes, Parkinson observed that some keratinocytes were relatively resistant to the effects of TPA (Parkinson et al. 1983). The TPA resistant cells were a subpopulation of clonogenic keratinocytes and were able to give rise to clonogenic TPA-sensitive cells. This was interpreted as evidence that the least differentiated cells were resistant to differentiation. A population of keratinocytes that appear resistant to differentiation is also seen after keratinocytes have been placed in suspension culture. 20-30\% of keratinocytes do not express involucrin after 24 hours in methyl cellulose (Adams and Watt 1989). Were these cells the rapidly adherent basal cells?

To investigate this question I placed cells that adhered to type IV collagen within 20 minutes in suspension in methyl cellulose for 24 hours (Green, 1977; Adams and Watt, 1989). Unfractionated keratinocytes were used as a control. In each of three experiments there was no significant difference between the percentage of involucrinpositive cells in the rapidly adhering cells and in the controls (Figure 3.12), indicating that basal cells with high CFE were as likely to undergo terminal differentiation when deprived of ECM as were unselected cells. 


\section{Tritiated thymidine incorporation by integrin-bright cells in post confluent cultures}

The stem cell model advocated by Lajtha and Potten predicts that when the rate at which cells leave the basal layer is constant, stem cells will be less likely to be in the cell cycle than transit amplifying cells (Lajtha, 1969; Potten, 1981). This is because several transit cell divisions are predicted for each stem cell division (see discussion in Chapter 1). I compared the uptake of tritiated thymidine ( ${ }^{3} \mathrm{HThy}$ ) in basal cells from post confluent cultures that had been pulse labelled for 1 hour with $20 \mu \mathrm{Ci} / \mathrm{ml}^{3} \mathrm{HThy}$ and then sorted into 3 groups on the basis of $\alpha_{2}$ integrin subunit expression as in Figure 3.1b. The results are shown in Figure 3.13. The cells with greatest tritiated thymidine uptake are those with mid level integrin expression. Both integrin-bright and integrin-dull cells are less likely to be in the cell cycle. An interpretation of these results is that the integrin-bright cells are mostly more slowly cycling stem cells, the integrin-dull cells are mostly post mitotic basal cells committed to undergo terminal differentiation and that the rapidly dividing transit cell population accounts for the increased thymidine uptake of the cells in the mid range of integrin expression

\section{Fate of cells which attach slowly to ECM}

Figure 3.6b illustrates that most of the keratinocytes capable of forming macroscopic colonies could be selected by their ability to adhere to type IV collagen for 20 minutes. If cells that did not attach to collagen within 60 minutes were plated onto feeders no colonies were visible (Figure 3.6b, central dish). What was the fate of keratinocytes that adhered slowly to ECM proteins?

I investigated this by panning keratinocytes onto type IV collagen for $60 \mathrm{~min}$ and then replating the unattached cells onto feeders. Dishes were fixed at intervals between 3 hr and 14 days. All adherent keratinocytes were detected by staining dishes with a broad spectrum anti-keratin antibody and keratinocytes that had initiated terminal differentiation were visualised with an anti-involucrin antibody. Anti-keratin staining 3 hours after plating established that over than $95 \%$ of cells attached as single cells.

Figure 3.14 illustrates the results of a typical experiment. By 14 days, the control (unfractionated) population had a colony forming efficiency (i.e. colonies of $>32$ cells) of $33 \% .70 \%$ of these colonies were greater than $2 \mathrm{~mm}$ diameter. In contrast, 
At 24 hours most of the attached cells that had not adhered to collagen were found as single cells, over half of which were involucrin-positive. There was a small proportion of doublets, most, but not all of which were involucrin-negative (Figure 3.14b). The fate of cells which did not form colonies of at least 32 cells was examined at intervals up to 14 days after plating (Figure 3.14c-f). Between 7 and 14 days the number of single cells fell by two thirds, but this appeared to reflect detachment of involucrin-positive cells as the proportion of 2-31 cell colonies did not increase. By 14 days all the cells in the $<32$ cell colonies were involucrin-positive. The appearance of several abortive colonies stained for involucrin is shown in Figure $3.6 \mathrm{c}-\mathrm{c}, \mathrm{g}$ and a colony of involucrin-negative cells is shown for comparison in Figure 3.6f. Thus the behaviour of slowly adhering cells is that which would be expected of committed progenitor cells.

\section{Discussion}

The hypothesised relationship between the proliferative potential of basal keratinocytes and their adhesiveness is supported by the results presented here. Cell sorting experiments demonstrated that the probability that a given basal cell would found a visible colony 2 weeks later was directly related to the level of $\beta_{1}$ integrin expression on its surface. Further cells that attached to ECM proteins rapidly were enriched for clonogenic cells. Consistent with the cell sorting results, these rapidly adherent cells are a subpopulation of basal cells with a higher than average level of surface $\beta_{1}$ integrins. An almost pure population of clonogenic cells was obtained by allowing cells to attach to type IV collagen for 20 minutes.

The definition of a stem cell offered at the start of this Chapter was based solely on the ability of a stem cell to found a colony of over 32 cells. However, most of the colonies formed were much larger and contained both differentiated and basal cells and had the morphology of holoclones and meroclones identified by Barrandon in single cell subcloning experiments (discussed in Chapter 1) (Barrandon and Green 1987b) . The integrin bright, rapidly adherent basal cells $\left(\beta_{1}{ }^{++}\right.$Ad fast $)$had other characteristics that matched those predicted for epidermal stem cells. They exhibited self renewal in that when cultured they produced new rapidly adherent cells. This is 
consistent with the holoclone and meroclone type morphology of most of the colonies as both of these colony types contain self renewing cells (Barrandon and Green 1987b). $\beta_{1}{ }^{++}$Ad fast cells also gave rise to slowly adhering cells which behave in the same manner as the transit amplifying population proposed by Potten (Potten and Hendry 1973; Potten 1974; Potten 1981; Potten and Morris 1988). These cells execute 1 to 5 rounds of cell division after which the founding cell and its progeny undergo terminal differentiation, revealed by their expression of involucrin. Consistent with the suggestion that stem cells are slow cycling in the steady state (Potten and Morris 1988; Cotsarelis et al. 1989), basal cells with the highest levels of surface $\beta_{1}$ integrin were less likely to be in the cell cycle in a post confluent culture than the basal cells with moderate expression levels.

Parkinson predicted that epidermal stem cells would be relatively resistant to stimuli that promoted terminal differentiation (Parkinson et al. 1983). Although the $\beta_{1}{ }^{++}$Ad fast cells had a high proliferative potential, they differentiated to the same extent as unselected basal cells when placed in suspension. DNA synthesis is irreversibly inhibited by 12 hours in suspension culture (Watt et al. 1988), so differentiation must have occurred without the cell having executed cell division. Thus stem cells can differentiate directly into post mitotic, terminally differentiated keratinocytes and do not have to complete a prerequisite number of cell divisions before the onset of terminal differentiation. Similar behaviour has been seen in haemopoietic precursor cell lines (Fairburn and Cowling 1993). The implications of this observation are discussed further in Chapter 7.

$\beta_{1}{ }^{++}$Adfast cells had good credentials as a population considerably enriched for epidermal stem cells. It was tempting to speculate that the same relationships between $\beta_{1}$ integrin mediated adhesiveness and proliferative potential may operate in vivo. If this was so it would offer an opportunity to localise stem cells in vivo and isolate them directly from epidermis. 
Chapter 3

Stem cells in vitro

Table 3.1: Involucrin expression and CFE of keratinocytes sorted on the basis of light scatter

\begin{tabular}{|c|c|c|c|}
\hline Region & $\begin{array}{c}\text { \% Involucrin } \\
\text { positive cells } \\
( \pm \text { SEM) }\end{array}$ & $\begin{array}{c}\text { Mean CFE } \\
(\% \pm \text { SEM) }\end{array}$ & $\begin{array}{c}\text { Relative CFE } \\
(\text { CFE of A/CFE of } \\
\text { B) }\end{array}$ \\
\hline A & $3.9( \pm 0.3)$ & $14( \pm 7.1)$ & 23.3 \\
\hline B & $51.5( \pm 3.6)$ & $0.4( \pm 0.2)$ & 1 \\
\hline
\end{tabular}


Table 3.2: Cell size and intensity of $\alpha_{2}$ integrin subunit staining in FACS sorted basal cells

\begin{tabular}{|c|c|c|c|}
\hline Sort group+ & $\begin{array}{c}\text { Mean cell } \\
\text { diameter }(\mu \mathrm{m} \pm \\
\text { SEM) }\end{array}$ & $\begin{array}{c}\text { Mean } \alpha_{2} \\
\text { fluorescence } \\
\text { (arbitrary } \\
\text { units) }\end{array}$ & $\begin{array}{c}\text { Relative } \\
\text { fluorescence } \\
\text { intensity * }\end{array}$ \\
\hline $0-20$ & $10.9 \pm 0.22$ & 12.2 & 1.00 \\
\hline $30-70$ & $11.0 \pm 0.26$ & 23.3 & 1.85 \\
\hline $80-100$ & $11.8 \pm 0.23$ & 43.2 & 2.98 \\
\hline
\end{tabular}

\section{Notes}

$+\quad$ See Figure 3.5A

* $\quad$ Ratio of (mean $\alpha_{2}$ fluorescence /(mean cell diameter) ${ }^{2}$ ) 
FIGURE 3.1: Flow cytometry of cultured keratinocytes

a) Dot plot showing the FSC and SSC of a single cell suspension of cultured keratinocytes. Each dot represents one cell. FSC and SSC are both measured in arbitrary units on a linear scale. 2 groups of cells were sorted, those in region A with low SSC and FSC and those in region $B$ with higher FSC and SSC. In the experiment shown, the mean CFE of cells from region $A$ was $28 \%( \pm 1.6 \%)$ and the mean CFE of cells from region B was $0.7 \%( \pm 0.3 \%)$.

b) Fluorescence histogram showing fluorescence of cells from region A which had been stained with HAS6-FITC, an antibody to the $\alpha_{2}$ integrin subunit that had been conjugated to FITC. Fluorescence, measured in arbitrary units on a log scale is shown on the $\mathrm{x}$ axis and cell number is shown on the $\mathrm{y}$ axis. The marker on the $\mathrm{x}$ axis indicates the upper limit of fluorescence of control cells stained with an anti CD8 antibody that had been conjugated to FITC. 


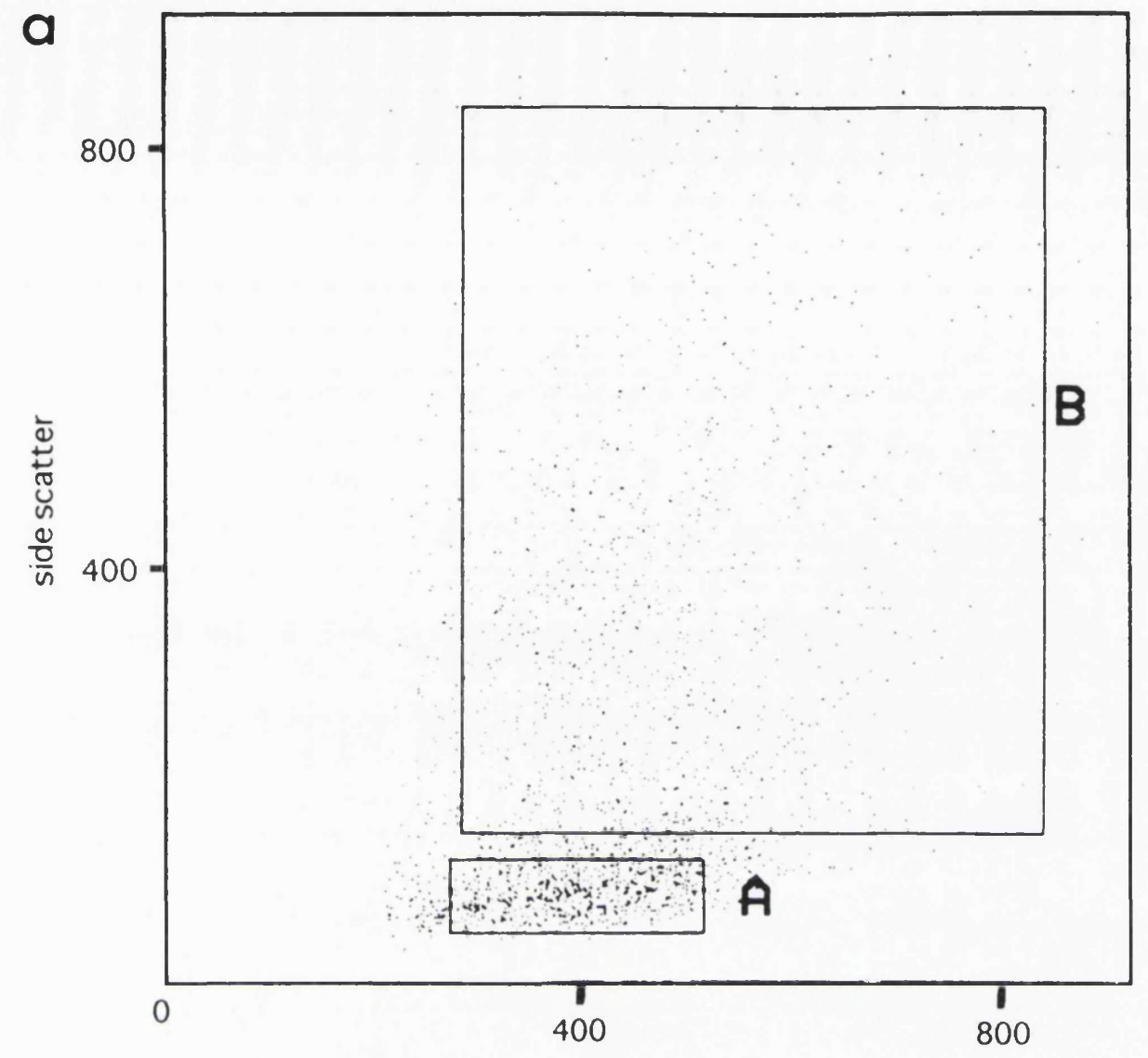

forward scatter

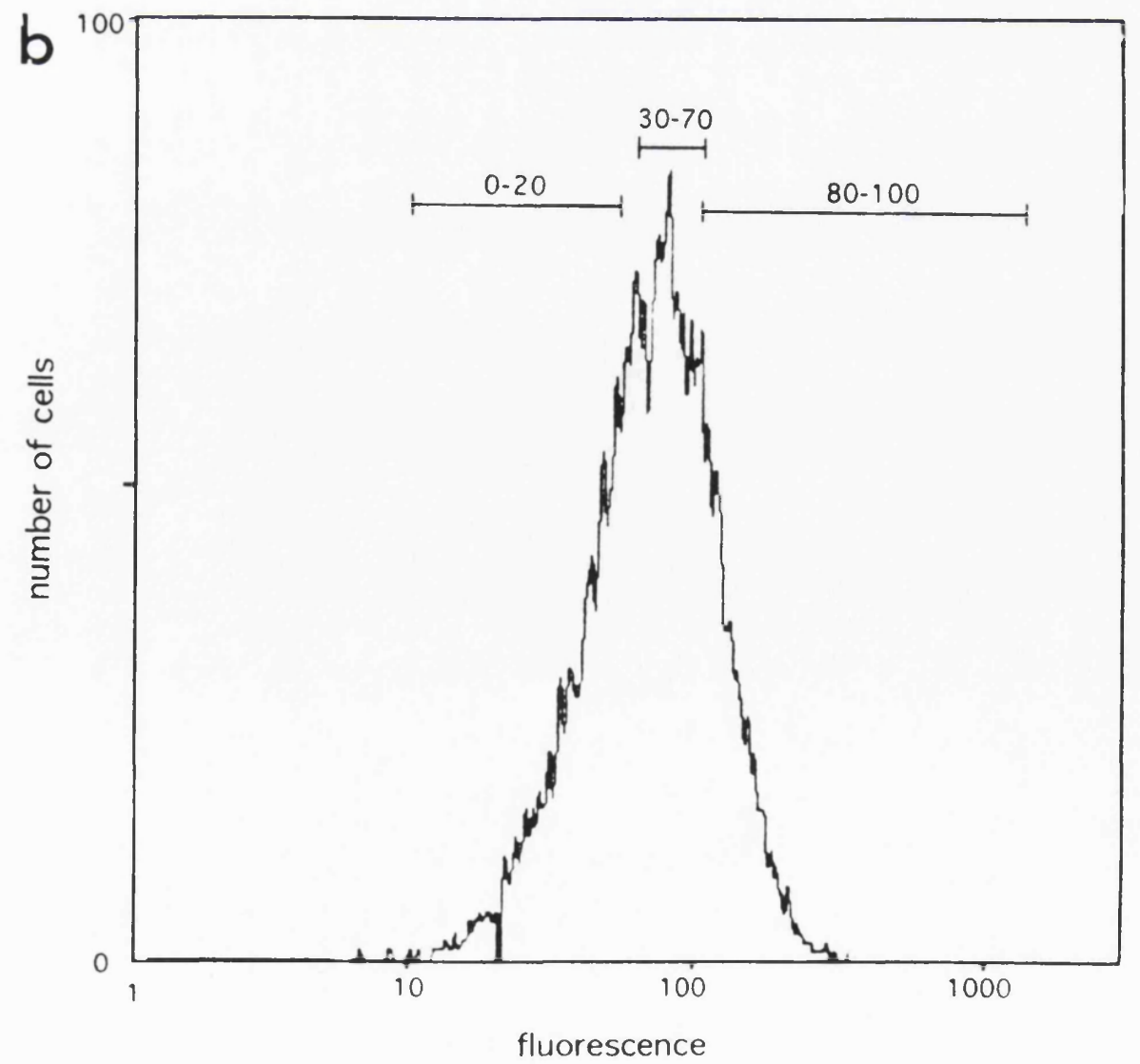


FIGURE 3.2: $\beta_{1}$ Integrin subunit expression and keratinocyte differentiation.

Cultured keratinocytes ( 2 days post confluence) were labelled with an antibody to the $\beta_{1}$ integrin subunit (anti CD 29) which was detected with FITC conjugated rabbit anti mouse IgG and with biotinylated PNA detected with streptavidin tricolor.

a-d Fluorescence histograms in which fluorescence is shown in arbitrary units on a $\log$ scale on the $\mathbf{x}$ axis and cell number is shown on the $y$ axis. The markers on the $x$ axis indicate the upper limit of fluorescence of control cells stained with CD8 antibody, detected with FITC conjugated rabbit anti mouse IgG (for CD29) and streptavidin tricolor alone (for PNA).

a, b: Fluorescence of unfractionated viable keratinocytes, stained for

a: The $\beta_{1}$ integrin subunit.

b: PNA.

c: $\beta_{1}$ integrin expression of cells gated for low PNA fluorescence, ie the left hand peak in panel $b$.

d: $\beta_{1}$ integrin expression of cells gated for high PNA fluorescence, ie the right hand peak in panel $b$.

The integrin dull cells are PNA bright and therefore suprabasal. 

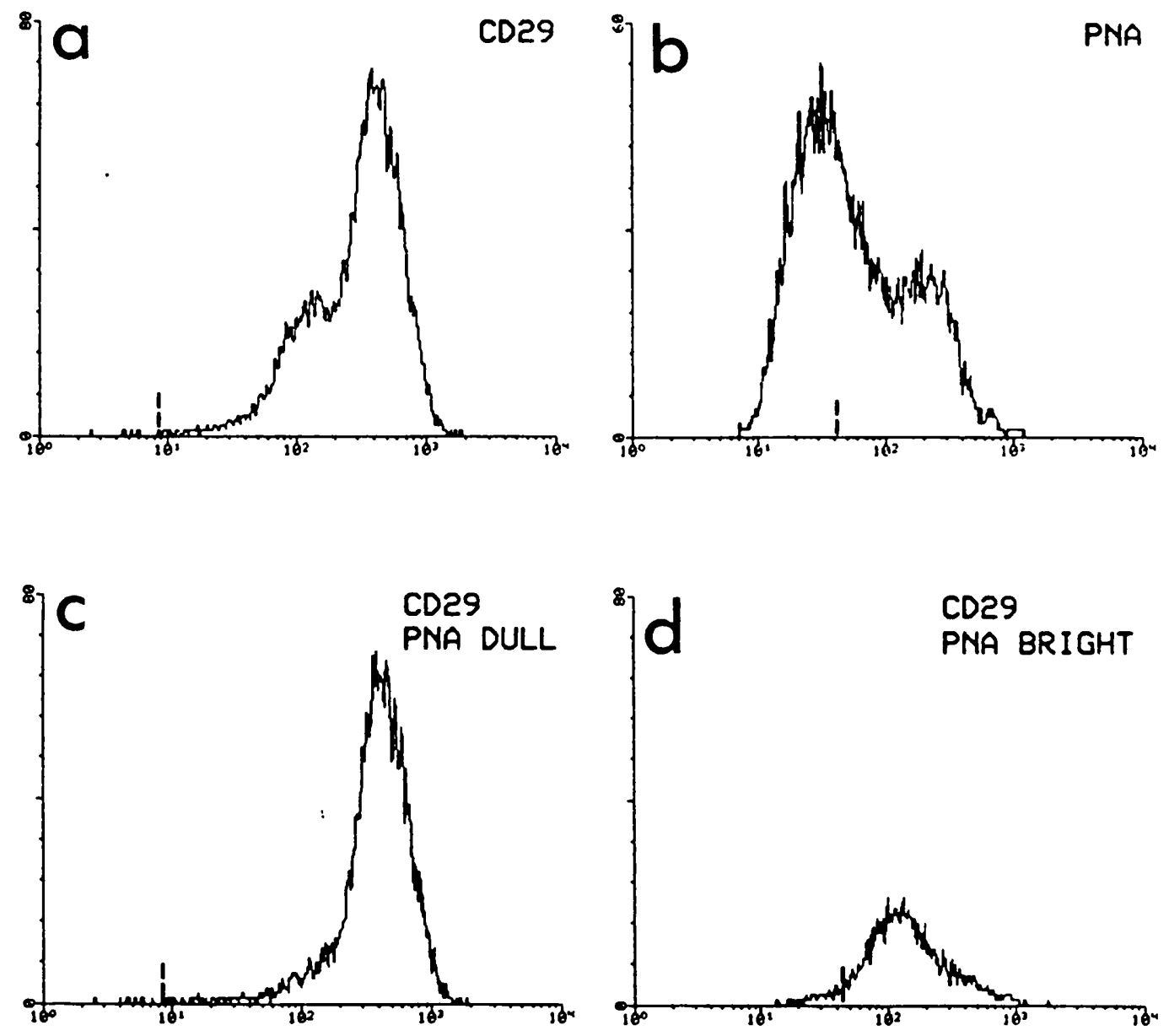

122 
FIGURE 3.3: $\beta_{1}$ Integrin subunit expression and keratinocyte differentiation.

Contour plot of PNA and $\beta 1$ integrin subunit expression. The same data for the unfractionated population as seen in Figure 3.2 panels $a$ and $b$ is shown as a contour plot. PNA fluorescence is on the $x$ axis and $\beta 1$ fluorescence on the $y$ axis, both in arbitrary units on a $\log$ scale. The number of cells with given fluorescence coordinates, is on the $\mathrm{z}$ axis, represented by the contour lines. The more contour lines the greater the number of cells. Integrin bright cells (A) are PNA dull basal cells and integrin dull cells (B) are PNA bright and therefore suprabasal. 


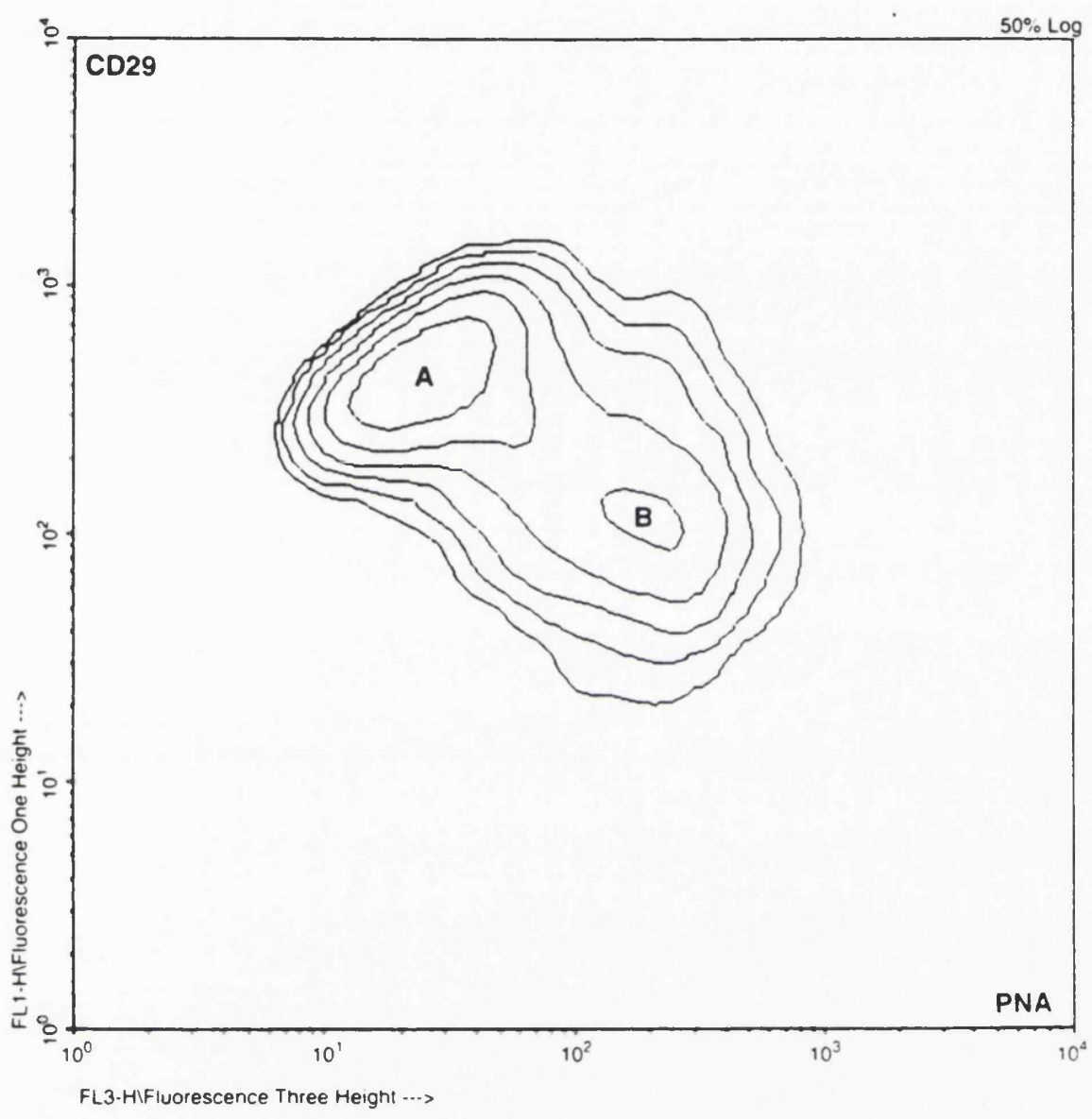


FIGURE 3.4: Expression of $\alpha_{2} \alpha_{3}, \alpha_{5}$ and $\alpha_{6}$ integrin subunits and keratinocyte differentiation.

Contour plots showing the fluorescence of unfractionated viable keratinocytes, harvested at confluence and double labelled for PNA and an integrin $\alpha$ subunit. A: $\alpha_{2}$, B: $\alpha_{3} ; C: \alpha_{5}$ and D: $\alpha_{6}$. Biotinylated PNA was detected with streptavidin. Integrin antibodies were HAS 6 and VM2, against the $\alpha_{2}$ and $\alpha_{3}$ integrin subunits respectively, both of which had been conjugated to FITC, and $\mathrm{mAb} 16$ and GoH3, against the $\alpha_{5}$ and $\alpha_{6}$ integrin subunits respectively, which were both detected with an FITC conjugated anti rat antibody. Fluorescence is shown in arbitrary units on a log scale with PNA on the $x$ axis and integrin on the $y$ axis. Cell number is on the $z$ axis, represented by contour lines. The markers on the axes show the upper limit of control fluorescence (anti CD8-FITC for $\alpha_{2}$ and $\alpha_{3}$, anti rat FITC for $\alpha_{5}$ and $\alpha_{6}$ and tricolor alone for PNA).

For each a subunit the level of expression decreases in PNA-bright suprabasal cells. For $\alpha_{3}$ and $\alpha_{6}$ there is a 10 fold decrease in fluorescence. $\alpha_{5}$ fluorescence decreases to a lesser extent and for $\alpha_{2}$ the decrease is only about 2 fold. 

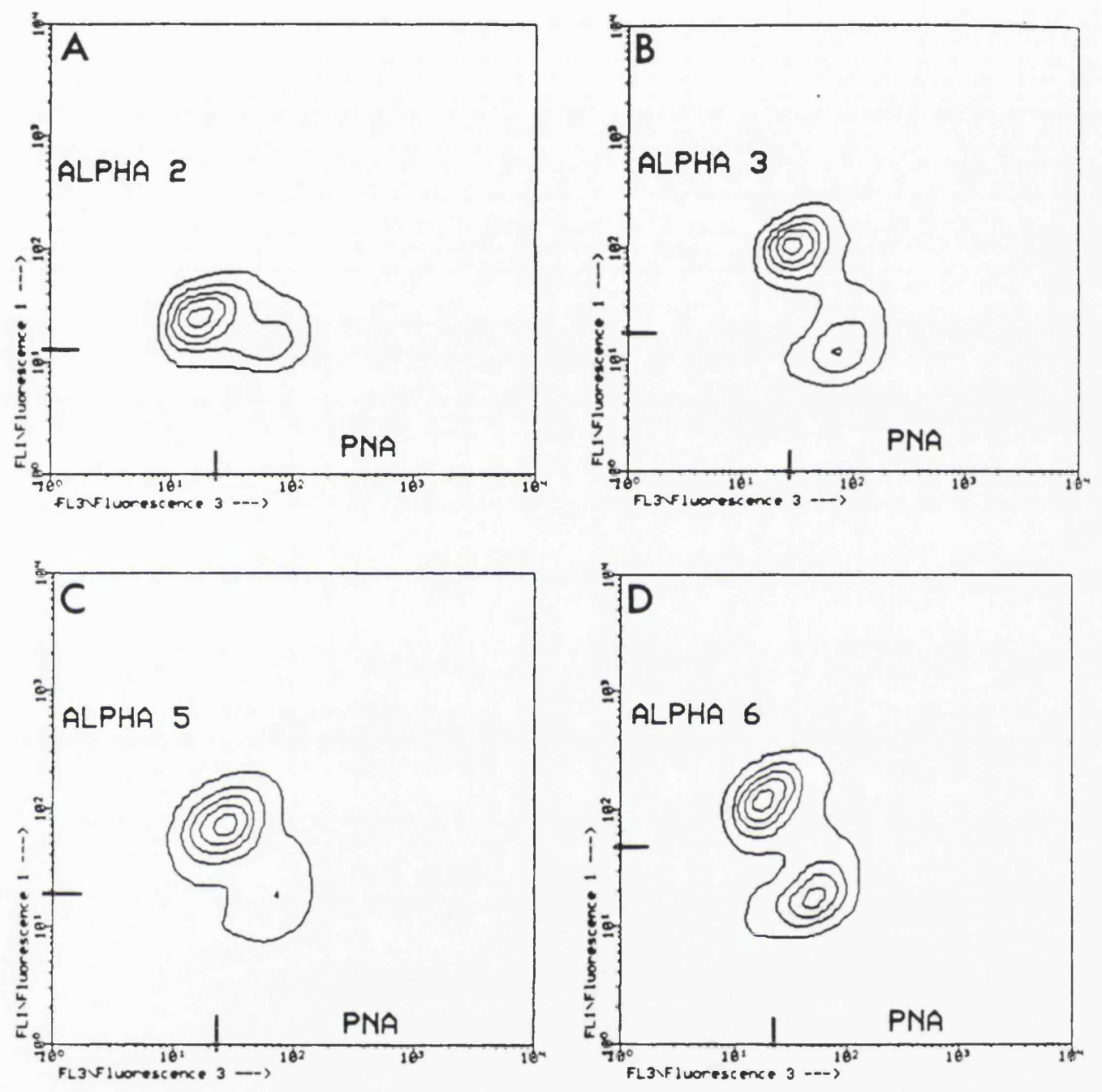

126 


\section{FIGURE 3.5: Effect of suspension-induced differentiation on integrin expression}

Preconfluent cultured keratinocytes were placed in suspension culture for 0 and 24 hours, harvested, stained for integrin subunits and analysed by flow cytometry.

A, B Dot plots showing the light scattering characteristics of keratinocytes after 0 hours (A) and 24 hours (B) in suspension. FSC is on the $x$ axis and SSC on the $y$ axis, both in arbitrary units on a linear scale. The regions containing involucrin negative cells (region A) and involucrin positive cells (region B) are shown in both panels (see Figure 3.1 and text). There is an increase in the proportion of cells in region B after 24 hours in suspension.

C-F Fluorescence histograms of unselected cells stained for integrin subunits. C: $\beta 1$, CD29-FITC; D $\alpha_{3}$, VM2-FITC; E $\alpha_{2}$, HAS6-FITC ; F $\alpha_{5}$ mAb 16 detected with anti rat IgG-FITC . Fluorescence is in arbitrary units on a log scale on the $x$ axis, cell number on the $y$ axis. The dotted line is the profile after 0 hours and the solid line the profile after 24 hours in suspension. The markers on the $x$ axis show the upper limit of fluorescence of control cells, the left hand marker for 0 hours and the right for 24 hours. Control staining was with CD8-FITC for $\beta 1, \alpha_{2}$ and $\alpha_{3}$ and with anti rat IgGFITC for $\alpha_{5}$.

After 24 hours in suspension a population of integrin-dull keratinocytes appeared, forming the left hand peak or shoulder in the 24 hour profiles. When the light scatter of cells in this population was examined, the cells were found to fall into region $B$ (see panel B). The modal fluorescence of cells in the right hand peak of integrin bright cells declines for $\alpha_{3}, \alpha_{5}$ and $\beta 1$ but remains unchanged for $\alpha_{2}$. 

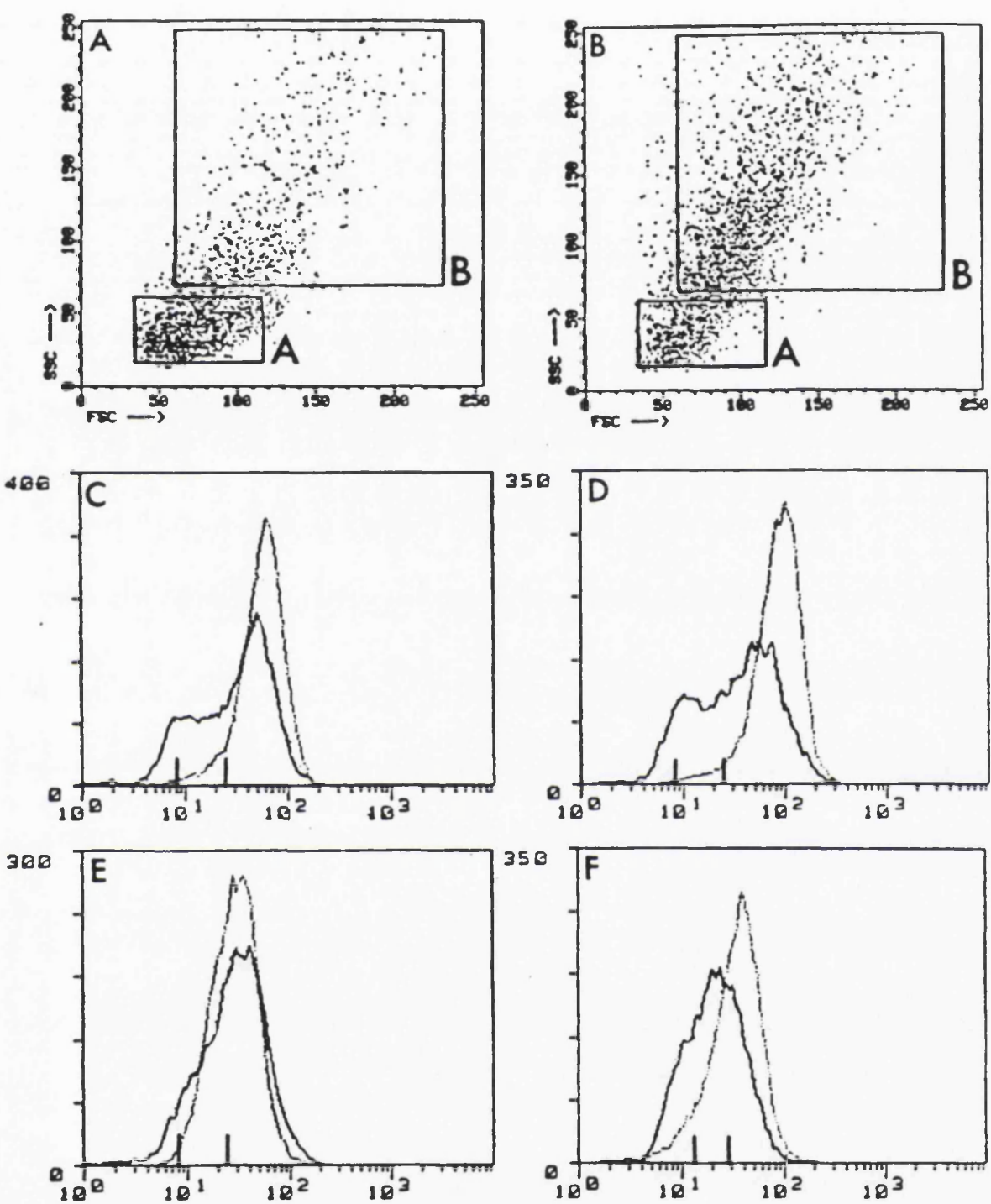


\section{FIGURE 3.6: Integrin expression and CFE in basal keratinocytes}

a) Basal keratinocytes stained with HAS6-FITC were sorted into 3 groups on the basis of expression of the $\alpha_{2}$ integrin subunit: the $20 \%$ with highest fluorescence (80-100), $40 \%$ with the modal fluorescence (30-70); and $20 \%$ of the population with lowest fluorescence (0-20), (see Figure 3.1b). Total basal cells were sorted as a control. Cells were plated onto feeders and colony forming efficiency determined after 14 days. Error bars show the standard error. The colony forming efficiencies of the cells with highest and lowest $\alpha_{2}$ expression were significantly different from control (both $\mathrm{p}<0.0005$ by $\chi 2$ test). Results shown are from a single experiment; two others gave similar results.

b) Cells were stained with anti CD29-FITC and sorted into 4 categories: the 5\% with highest fluorescence (95-100), the next 15\% (80-95), the mid 40\% (30-70) and the $20 \%$ with lowest fluorescence (0-20). Error bars show the standard error. The experiment shown is a typical example. Three others gave similar results. The colony forming efficiencies of the brightest $5 \%$ and the dullest $20 \%$ of cells were significantly different from control $\left(p<0.005\right.$ and $p<0.025$ respectively, $\chi^{2}$ test). There is a linear relationship between $\log$ fluorescence and CFE $(p<0.0001$, analysis of covariance, using data from 4 experiments).

c) Colony forming efficiencies of basal cells stained for the $\alpha_{6}$ integrin subunit and sorted into 3 groups: the $20 \%$ with highest fluorescence (100-80), mid 40\% (30-70) and the $20 \%$ with lowest fluorescence $(0-20)$ with all basal cells as a control. Results shown are from a single experiment; two others gave similar results. In 3 experiments no group had a CFE significantly different from the control CFE ( $>0.05$ by $\chi^{2}$ test).

d-f) Contour plots showing expression of $\alpha_{2}, \alpha_{3}$ and $\alpha_{5}$ integrin subunits in basal keratinocytes. Cells were labelled with a biotinylated anti $\alpha_{3}$ antibody detected with a streptavidin Tricolor conjugate, an anti $\alpha_{5}$ antibody detected with a phycoerythrin conjugated second antibody and an anti $\alpha_{2}$ antibody directly conjugated to FITC. Markers on each axis show the upper limit of fluorescence due to controls (anti CD8FITC for $\alpha_{2}$, PBS + Tricolor for $\alpha_{3}$ and PBS + anti rat phycoerythrin for $\alpha_{5}$ ). Cells that expressed the highest level of $\alpha_{2}$ also expressed the highest levels of $\alpha_{3}$ and $\alpha_{5}$. Results are a typical example of experiments. 

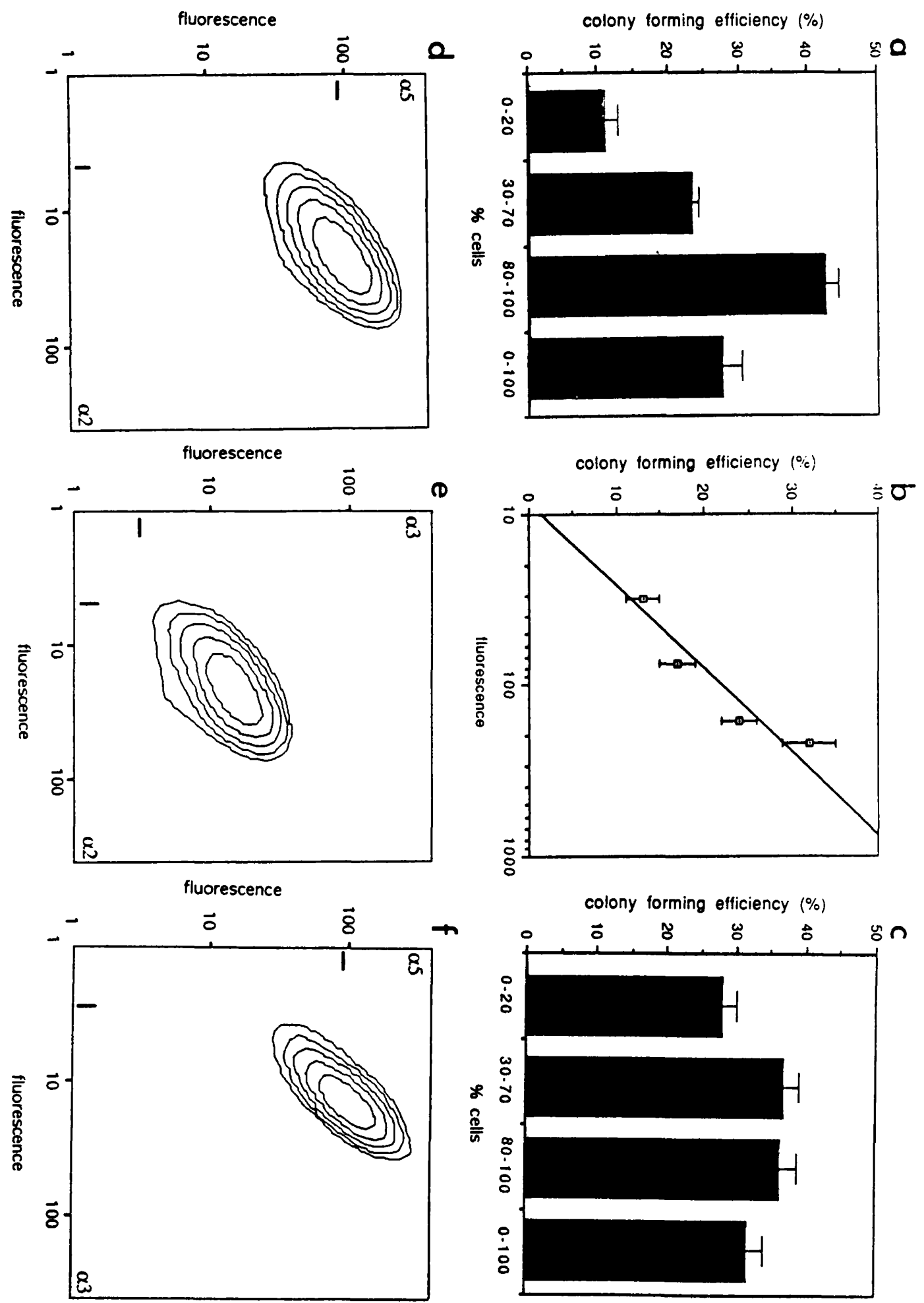


\section{FIGURE 3.7: Appearance of colonies formed by basal keratinocytes}

a) Basal keratinocytes were sorted on the basis of $\alpha_{2}$ integrin subunit expression (Figures 3.1b, 3.5a). 100 cells were sorted into each dish and cultured for 14 days. The upper dishes (from left to right were the $20 \%$ of cells with highest fluorescence, the mid $40 \%$ and the $20 \%$ with the lowest fluorescence; the lower dish is the control (all basal cells). Scale bar $=1 \mathrm{~cm}$. Dishes were stained with Rhodanile blue which stains keratinocyte colonies more intensely than the $3 \mathrm{~T} 3$ cells.

b) 1000 cells were plated onto type IV collagen-coated dishes for different lengths of time. In the left hand dish cells were allowed to adhere for $20 \mathrm{~min}$, non adherent cells were then removed and feeders added. Cells that failed to attach to collagen in 60 minutes were transferred into the middle dish. In the right hand (control) dish cells were allowed to adhere undisturbed. Scale bar $=1 \mathrm{~cm}$. Keratinocytes were detected by LP34 staining, visualised with anti mouse horseradish peroxidase and diaminobenzidine/ $\mathrm{CoCl}_{2}$, and counterstained with rhodanile blue.

c - e,g) Abortive colonies formed by cells which did not attach to type IV collagen in $60 \mathrm{~min}$. f: an actively growing 32 cell colony of involucrin-negative cells founded by a rapidly adherent cell. Cells were stained for involucrin and photographed under phase contrast. Scale bar $=40 \mu \mathrm{m}$.

c) 2 cell colony, both cells positive for involucrin, at 7 days.

d) 4 cell colony, all cells positive for involucrin, at 5 days.

e) 10 cell colony, 1 cell involucrin positive, at 5 days.

f) 32 cell colony, all cells involucrin-negative, at 3 days.

g) 24 cell colony, all cells involucrin-positive at 7 days. 


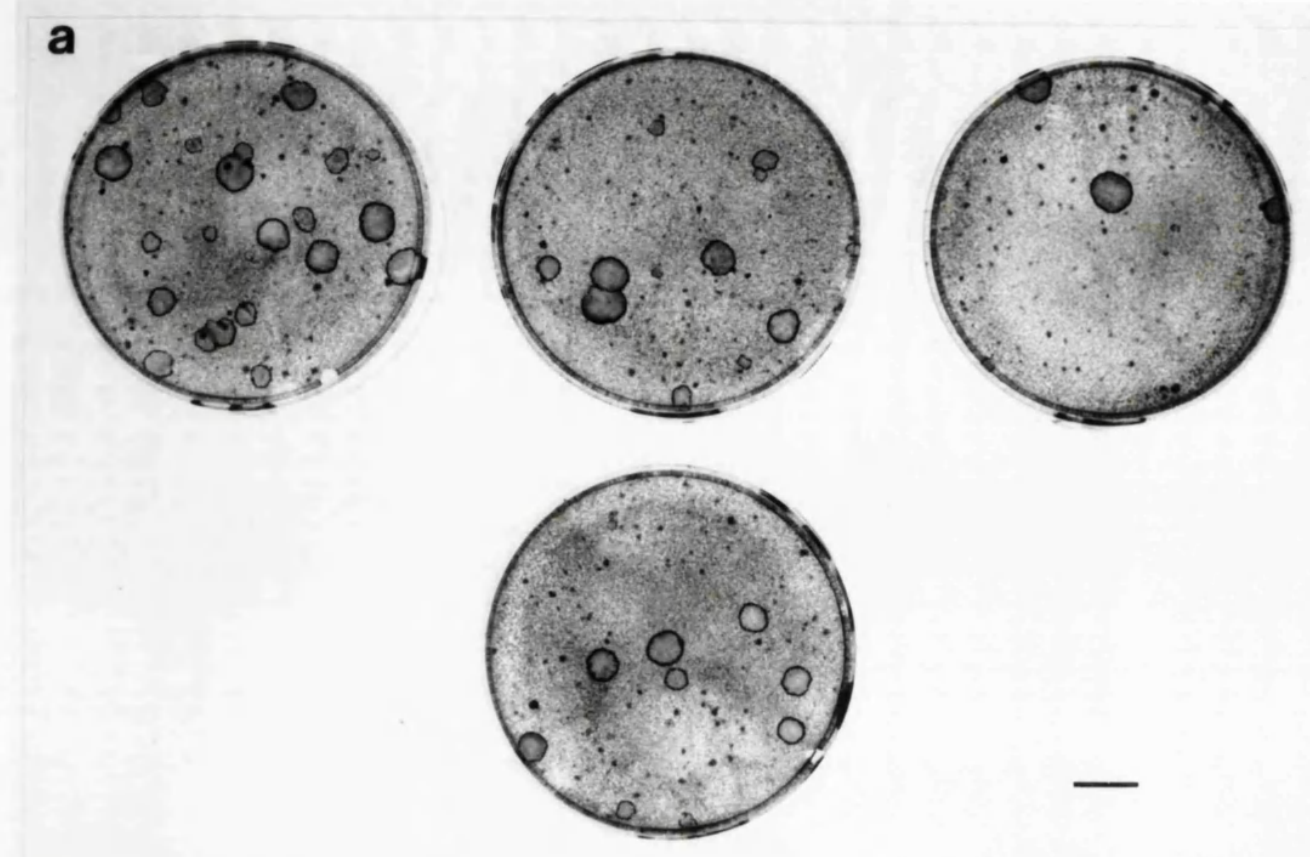

b
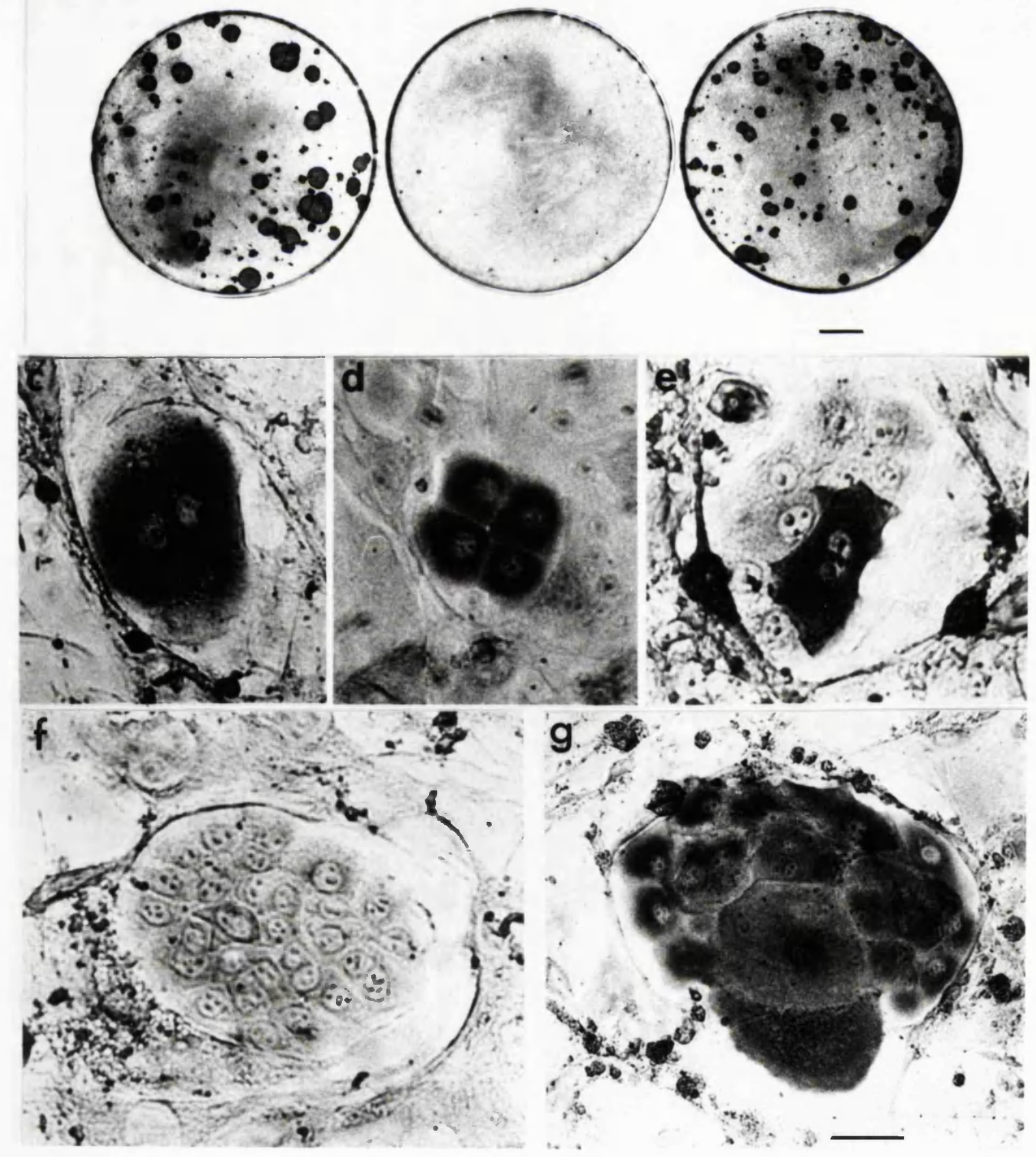
FIGURE 3.8: CFE of basal keratinocytes sorted simultaneously for $\alpha_{2}, \alpha_{3}$ and $\alpha_{5}$ integrin subunit expression

Cultured keratinocytes were sorted by flow cytometry after being stained for the $\alpha_{2}$, $\alpha_{3}$ and $\alpha_{3}$ integrin subunits using the same antibodies as in Figure 3.6, d-f. Basal cells were isolated by light scatter as in Figure 3.1 and the cells sorted into 4 groupsall basal cells (control), $20 \%$ of basal cells brightest in $\alpha_{2}$ subunit fluorescence $\left(\alpha_{2}{ }^{++}\right)$, the cells in the $\alpha_{2}{ }^{++}$group which were brightest for $\alpha_{3}$ and $\alpha_{5}\left(\alpha_{2}{ }^{++}, \alpha_{3}{ }^{++}\right.$, $\left.\alpha_{5}{ }^{++}\right)$and the cells in the $\alpha_{2}{ }^{++}$group which were dullest for $\alpha_{3}$ and $\alpha_{5}\left(\alpha_{2}{ }^{++}, \alpha_{3}{ }^{+}\right.$, $\left.\alpha_{5}^{+}\right)$.

a) Contour plot showing the $\alpha_{3}$ and $\alpha_{5}$ integrin subunit fluorescence of the $20 \%$ of basal cells brightest in $\alpha_{2}$ fluorescence. Fluorescence is on a log scale in arbitrary units for $\alpha_{3}$ (y axis) and $\alpha_{5}$ ( $x$ axis). Cell number is indicated by the number of contour lines. Gates were set as shown to sub fractionate the $\alpha_{2}$ bright cells into 2 groups with different $\alpha_{3}$ and $\alpha_{5}$ fluorescence intensity. The $\left(\alpha_{2}{ }^{++}, \alpha_{3}{ }^{++}, \alpha_{5}{ }^{++}\right)$ cells had 1.9 fold greater mean $\alpha_{3}$ fluorescence and 1.8 fold greater mean $\alpha_{5}$ fluorescence compared with the $\left(\alpha_{2}{ }^{++}, \alpha_{3}{ }^{+}, \alpha_{5}{ }^{+}\right)$group.

b) Graph showing the colony forming efficiencies of cells from each sort group after 2 weeks of culture. Error bars show the standard error of the mean.

There was no significant increase in CFE of the $\left(\alpha_{2}{ }^{++}, \alpha_{3}++, \alpha_{5}{ }^{++}\right)$cells as compared with the $\alpha_{2}{ }^{++}$cells $\left(\mathrm{P}>0.10, \chi^{2}\right.$ test), though the $\left(\alpha_{2}{ }^{++}, \alpha_{3}{ }^{++}, \alpha_{5}{ }^{++}\right)$cells had a significantly higher CFE than both the $\left(\alpha_{2}{ }^{++}, \alpha_{3}{ }^{+}, \alpha_{5}{ }^{+}\right)$cells $\left(\mathrm{P}=0.037 \chi^{2}\right.$ test) and the control group $\left(P=0.006, \chi^{2}\right.$ test). Three colour sorting does not offer a significant improvement in CFE over single colour sorting. 


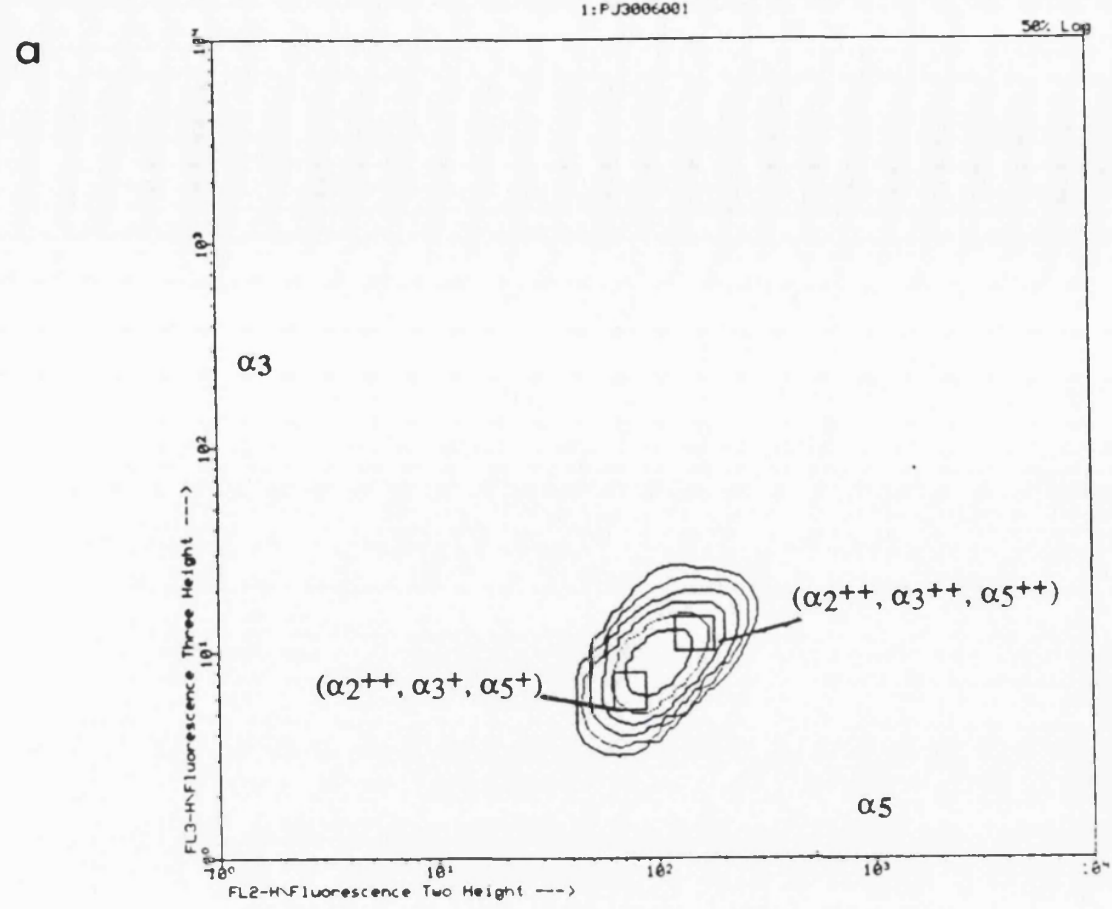

b

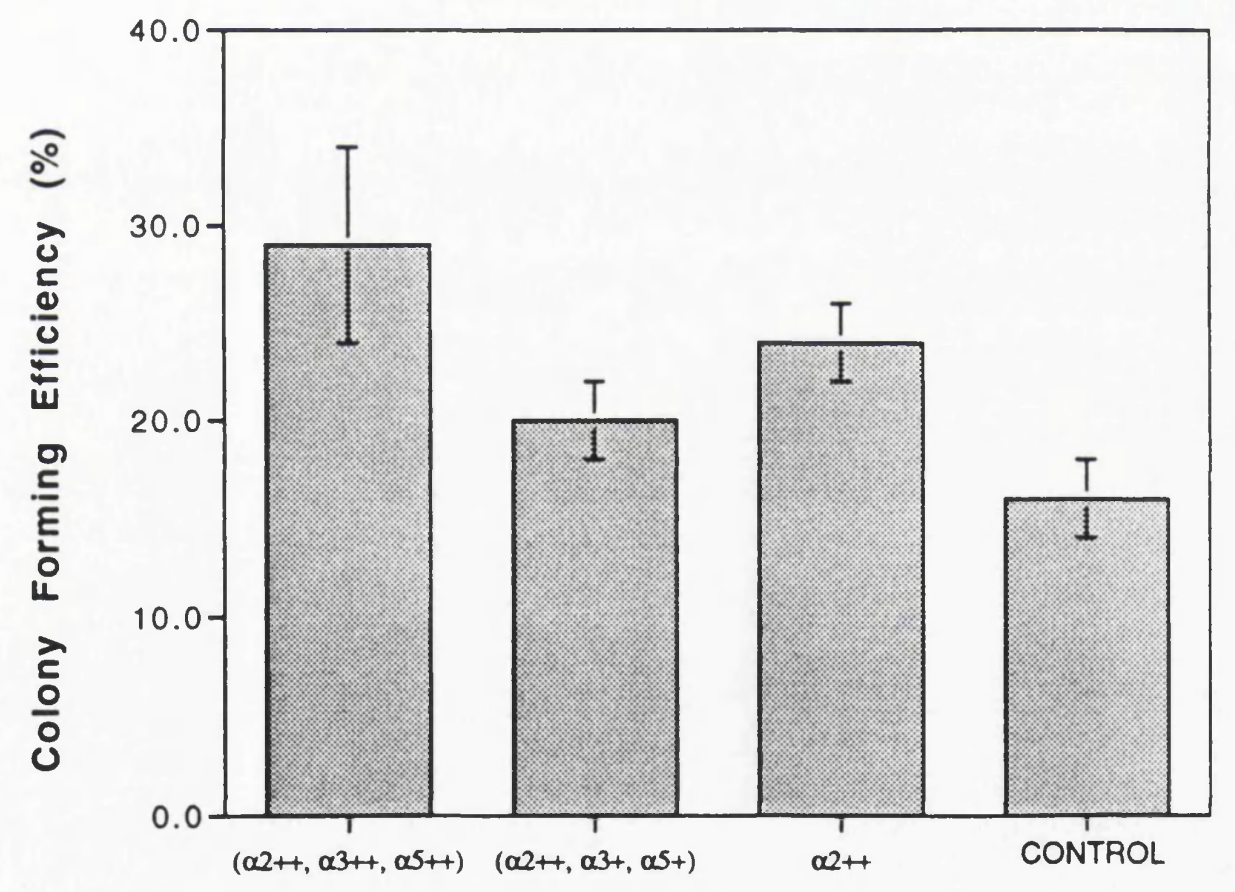

Sort Gate 
FIGURE 3.9: CFE of basal keratinocytes adhering to ECM proteins at different rates

A) CFE of cells plated for different lengths of time onto type IV collagen, $100 \mu \mathrm{g} / \mathrm{ml}$; laminin 1, $25 \mu \mathrm{g} / \mathrm{ml}$; fibronectin, $10 \mu \mathrm{g} / \mathrm{ml}$; and keratinocyte ECM. Unsorted cells were plated directly onto feeders as a control; the percentage of involucrin-positive cells in the control was determined and the control CFE calculated as the number of colonies/number of involucrin-negative cells in the control sample. CFEs are expressed as a ratio of the control CFE. Results show typical examples from 3 experiments on each ECM protein.

B) Unfractionated cells were plated onto dishes coated with type IV collagen (100 $\mu \mathrm{g} / \mathrm{ml}$ ) for various times and the attached cells were harvested and plated onto feeders. CFE was scored after 2 weeks. For the control sample unfractionated keratinocytes were plated directly onto feeders. The percentage of involucrin-positive cells in the total population was determined. CFE is shown in black and \% of total basal (i.e. involucrin-negative) cells plated that attached at each time point is shown with hatched markings.

C) Cells plated on type IV collagen for $20 \mathrm{~min}$ were harvested and stained for the $\alpha_{2}$ integrin subunit with HAS6-FITC antibody. A control sample of unsorted keratinocytes was stained with the same antibody. Samples were then analysed on a FACScan flow cytometer. The fluorescence of basal cells in the control sample was compared to that of the adherent cells. The marker shows the upper limit of control antibody fluorescence (anti CD8-FITC). Fluorescence is measured in arbitrary units on a log scale. 
a

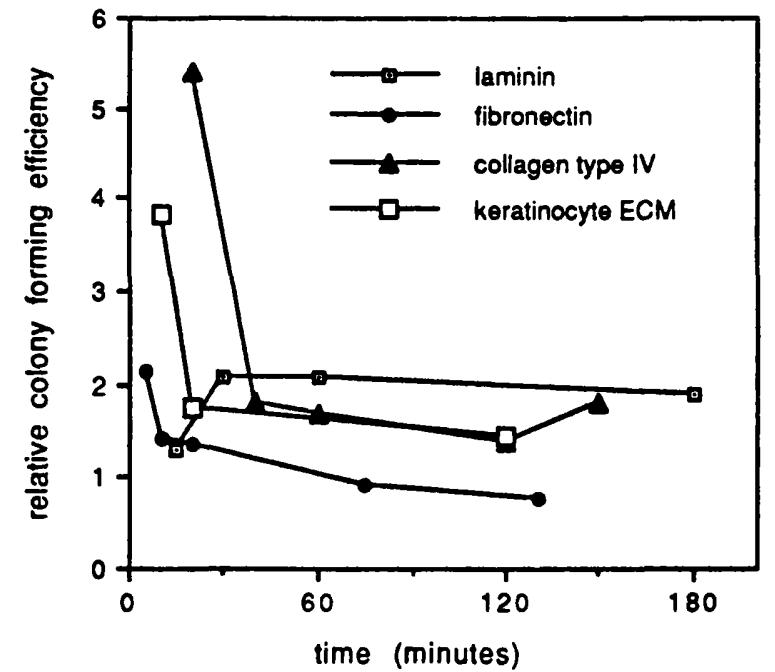

b

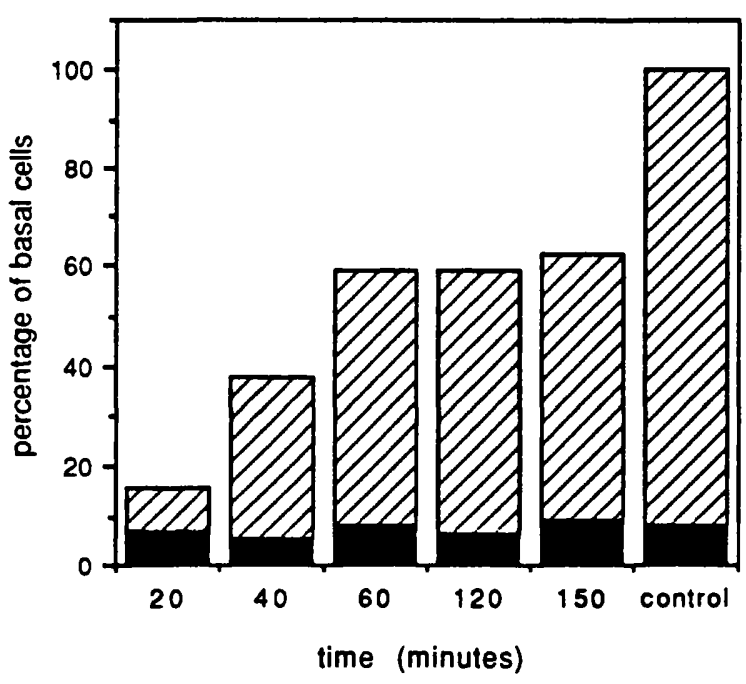

C

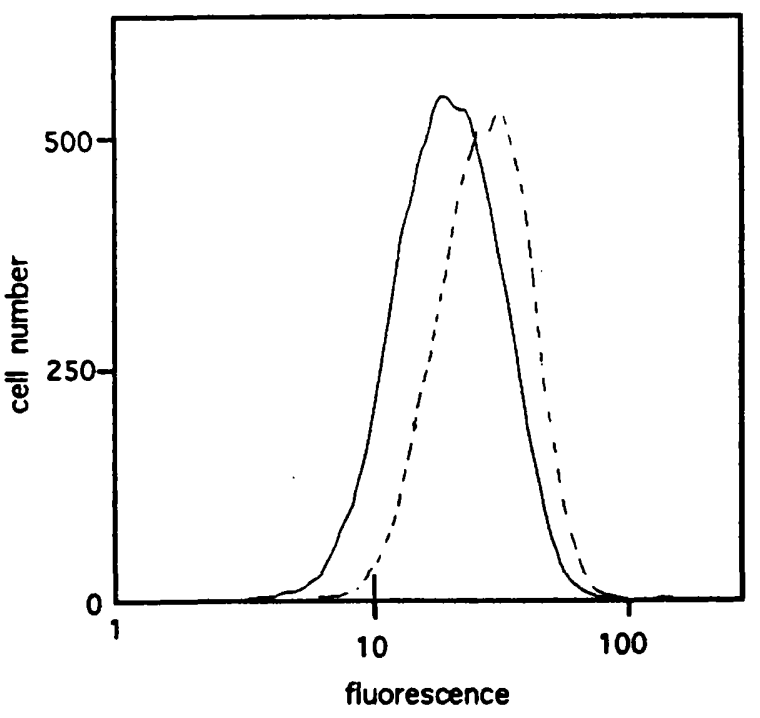


FIGURE 3.10: CFE of unfractionated basal cells placed in suspension culture for 0 to 5 hours.

Unfractionated keratinocytes were placed in suspension for up to 5 hours, plated on to feeders and the CFE determined after 14 days in culture. The results are expressed as a percentage of the CFE after 0 hours in suspension, error bars show the standard error. 


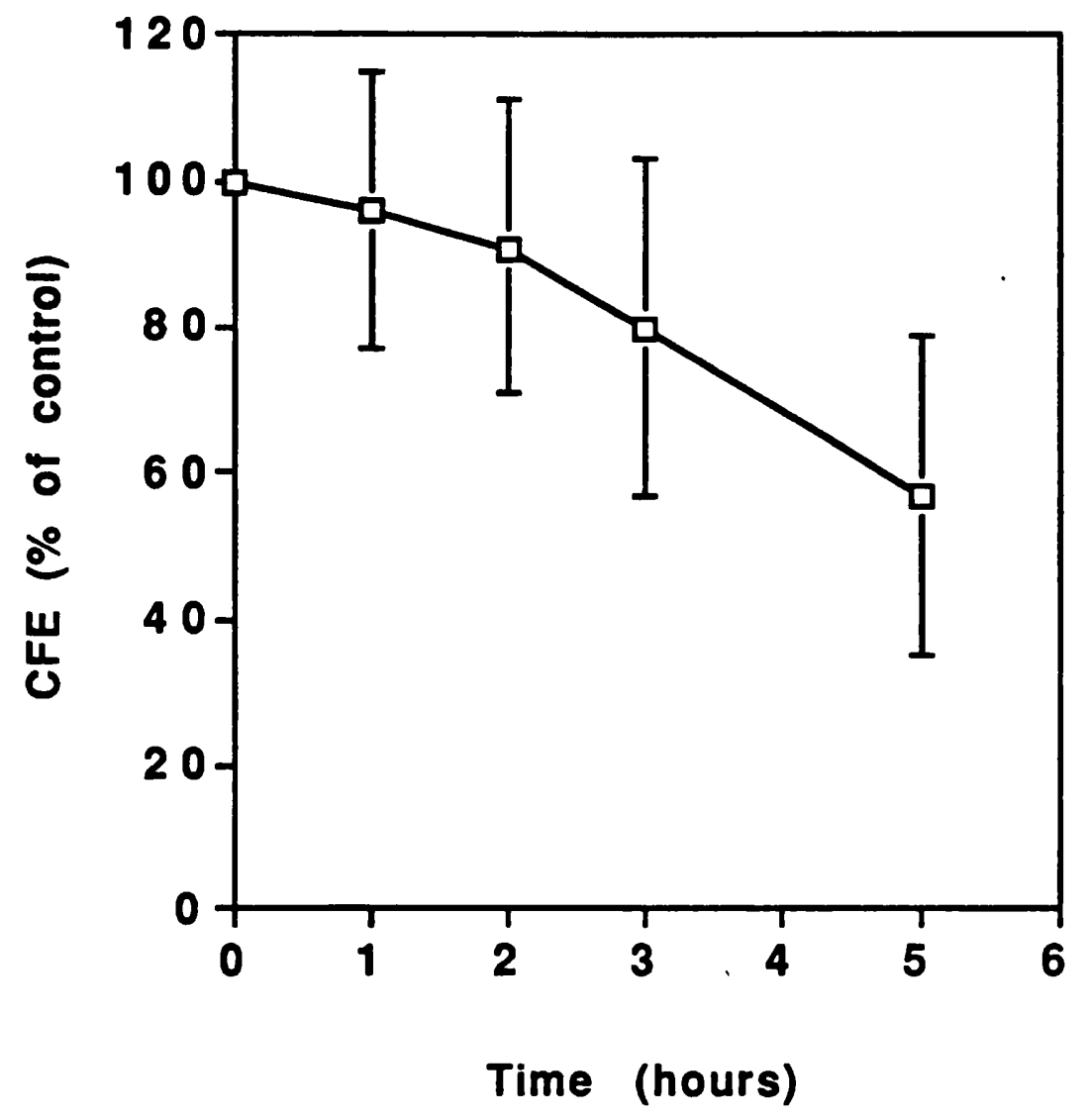




\section{FIGURE 3.11: Self renewal and differentiation of rapidly adherent cells}

$4 \times 10^{4}$ unfractionated keratinocytes were allowed to adhere for 20 minutes to a $100 \mathrm{~mm}$ diameter dish that had been coated with $100 \mu \mathrm{g} / \mathrm{ml}$ type IV collagen and then blocked with $0.5 \mathrm{mg} / \mathrm{ml}$ BSA. The non adherent cells were then removed and the dish cultured for 9 days, ie one day post confluence. The number of rapidly adherent cells that had founded the culture was determined by counting the number of cells in a duplicate dish after staining them with $1 \%$ methylene blue. The cultured cells were harvested. Some cells were stained for the $\alpha_{2}, \alpha_{3} \alpha_{6}$ and $\beta_{1}$ integrin subunits using the antibodies HAS6-FITC, VM2-FITC, GoH3-FITC and anti CD29-FITC respectively, and analysed by FACS. Cells stained with CD8-FITC were used as a control. The rest of the harvested cells were allowed to attach to dishes coated with $100 \mu \mathrm{g} / \mathrm{ml}$ type IV collagen and blocked with $0.5 \mathrm{mg} / \mathrm{ml} \mathrm{BSA}$ for 20,60 and 180 minutes. At each time point the non adherent cells were then removed and the adherent cells counted after staining with $1 \%$ methylene blue. The percentage of involucrin-positive cells was determined by staining cells air dried onto coverslips with SY3 visualised with rabbit anti mouse-FITC.

a) Light scatter characteristics of harvested cells. The $x$ axis shows FSC ion a linear scale and the $y$ axis SSC on a linear scale both in arbitrary units. Both suprabasal and basal cells are present (compare with Figure 3.1a).

b) and c) FACS profiles of cells stained for the $\beta_{1}(b)$ and $\alpha_{3}$ (c) integrin subunits. The $x$ axis shows fluorescence in arbitrary units on a log scale on and the $y$ axis cell number on a linear scale. The marker shows upper limit of fluorescence with anti CD8-FITC. The profiles closely resemble those seen with cultures from unfractionated cells (compare with Figure 3.5). Similar results were seen with $\alpha_{6}$ and $\alpha_{2}$ (not shown).

d) The average number of cells of different types generated by each rapidly adherent cell that founded the culture, calculated by dividing the number of each cell type in the culture by the number of rapidly adherent cells. 0-20: cells adherent to collagen within 20 minutes, 20-60: cells adhering between 20 and 20 minutes, 60-180: cells which adhere between 1 and 3 hours, non ad: non adherent basal cells, suprabasal: involucrin positive cells. A total of $1.2 \times 10^{7}$ cells of all types were produced by the 14000 rapidly adherent cells that founded the culture, an average of 880 keratinocytes each. 
a
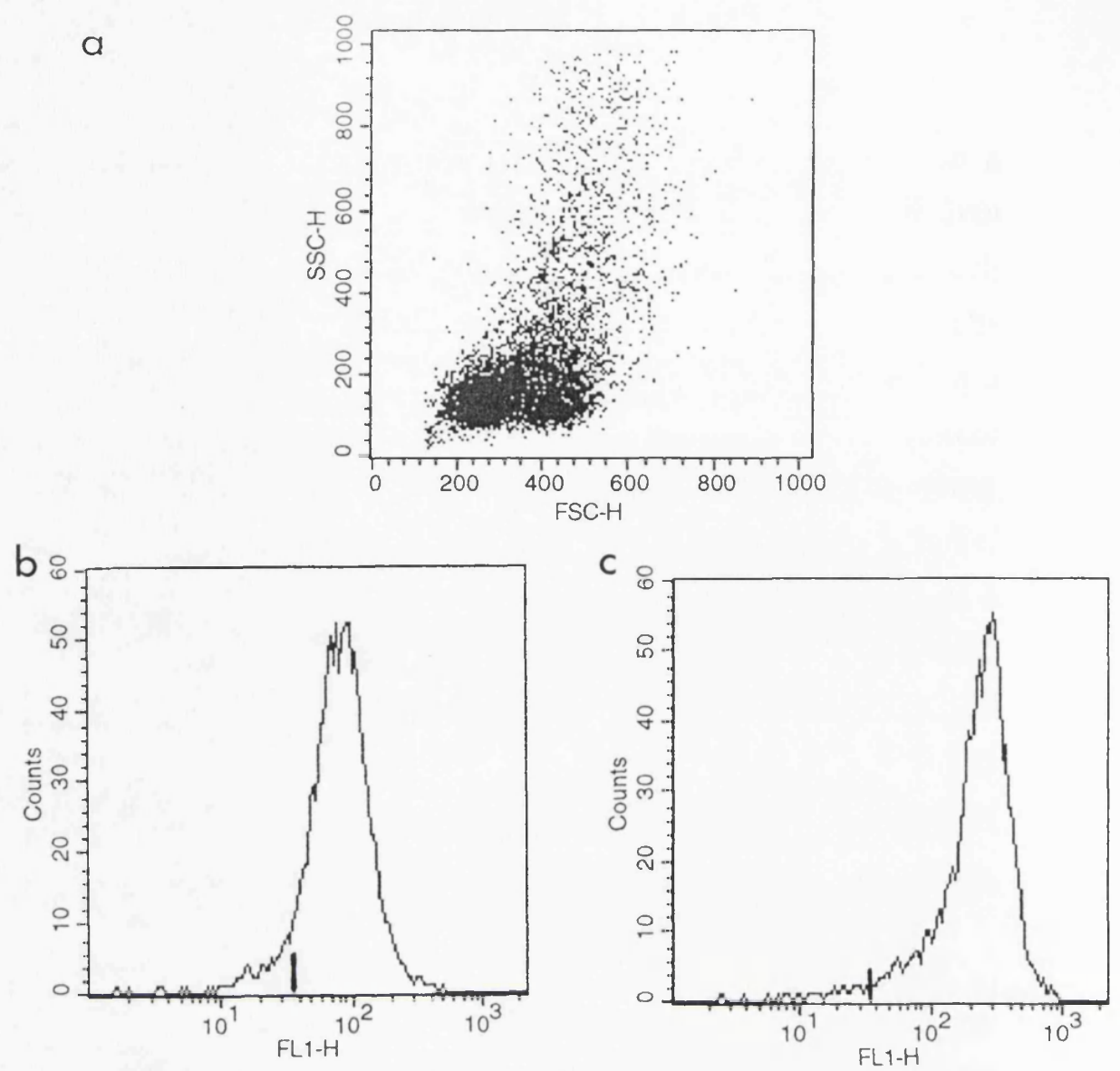

$d$
$=$
वे
वे
d
है

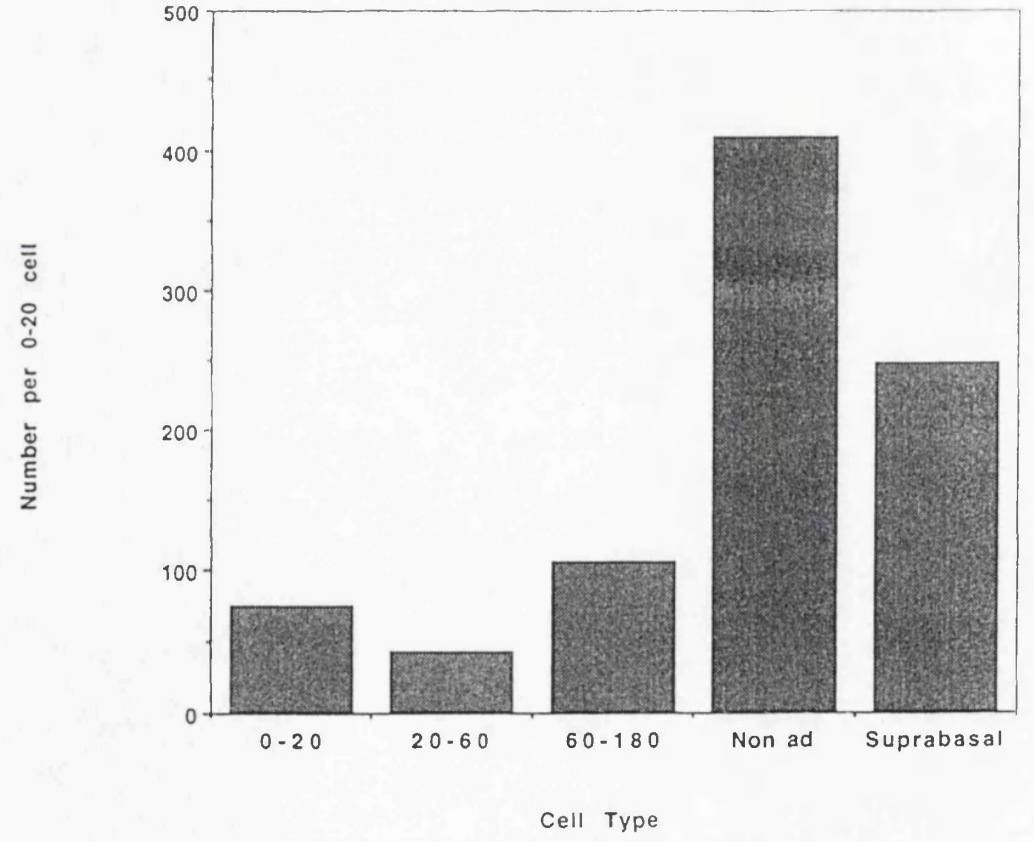




\section{FIGURE 3.12: Suspension induced differentiation of rapidly adherent and}

unselected basal cells

Cells which adhered to type IV collagen in 20 min were harvested and resuspended in methyl cellulose medium. Unfractionated cells were also suspended in methyl cellulose as a control. The percentage of involucrin-positive cells was measured at the start of the experiment and after 24 hours. The results of a typical experiment are shown \pm standard error of the mean. The percentage of involucrin-positive cells at 24 hours was not significantly different in the control and adherent cells in any of 3 replicate experiments ( $P>0.05, \chi^{2}$ test), despite the fact that the rapidly adherent cell population contained significantly fewer involucrin positive cells at the start of the experiment $\left(p<0.001, \chi^{2}\right.$ test).

Fast 0: rapidly adherent cells at time 0 .

Fast 24: rapidly adherent cells after 24 hours in suspension.

Con 0: unfractionated cells at time 0 .

Con 24: unfractionated cells after 24 hours in suspension. 


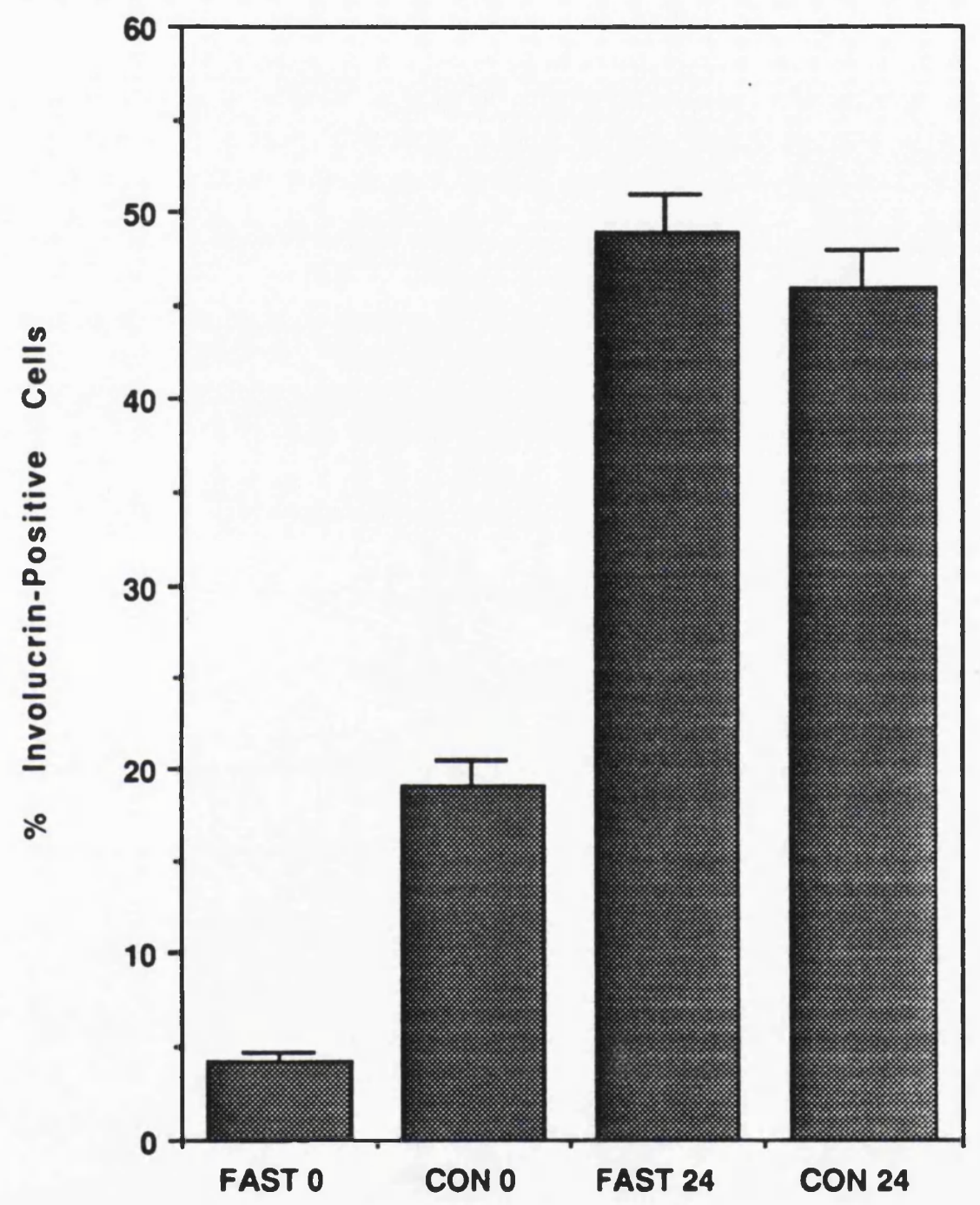


FIGURE 3.13: Cell cycle kinetics and integrin expression in post confluent keratinocyte cultures.

Post confluent cultures of neonatal foreskin keratinocytes were incubated with 20 $\mu \mathrm{Ci} / \mathrm{ml}$ tritiated thymidine for $1 \mathrm{hr}$. The cells were then harvested, stained with HAS6-FITC anti $\alpha_{2}$ integrin subunit antibody, and fixed in 1\% paraformaldehyde solution. Cells were then sorted into 3 groups: the $20 \%$ with highest integrin expression, the mid $40 \%$ of the population and the $20 \%$ with lowest expression. After sorting cells were resuspended in $5 \%$ trichloroacetic acid and the precipitated counts measured in scintillant.

The graph shows the incorporated counts per $10^{5}$ sorted cells in each group, on the $y$ axis, plotted against the relative mean $\alpha_{2}$ subunit fluorescence expressed as a ratio of the mean fluorescence of the dullest group of sorted cells, on the $x$ axis. The incorporated counts in the cells in the middle group were significantly greater than the cells in the integrin-dull and integrin bright groups $(\mathrm{P}=0.008$ and $\mathrm{P}=0.021$ respectively by Student's t-test). The results are from 1 experiment; 2 other experiments gave similar results. 


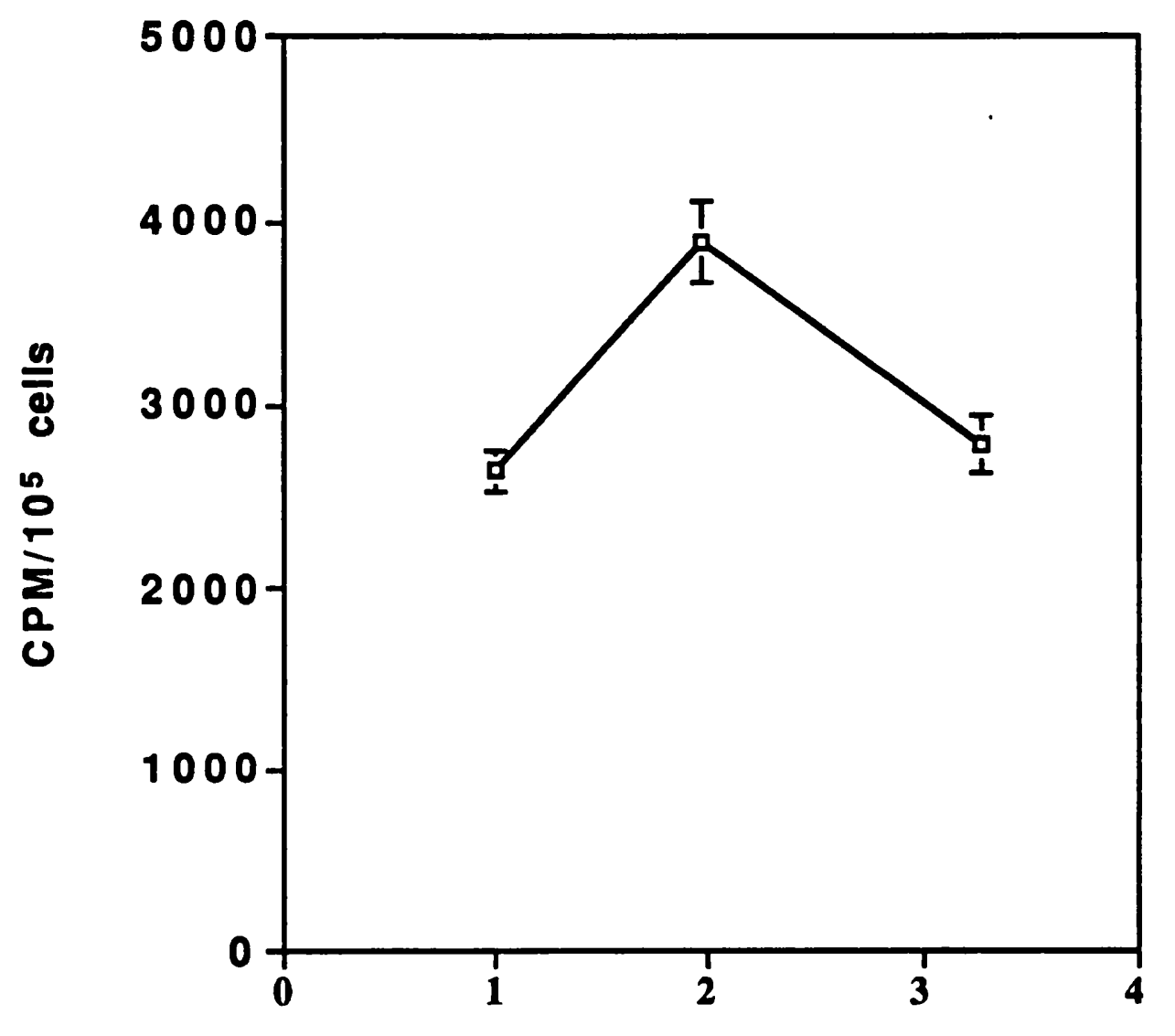

Relative Mean Fluorescence 
FIGURE 3.14 : Fate of cells that did not adhere rapidly to type IV collagen

Keratinocytes were plated onto a type IV collagen coated dish for $60 \mathrm{~min}$. The cells which did not attach were then plated onto feeders and cultured for up to 2 weeks. Unsorted cells were plated as a control.

\section{a) CFE}

Dishes were fixed and colonies counted at 14 days. The size and number of colonies and abortive colonies (under 32 cells) was scored. Colony size was divided into single cells (1), 2-3 cells (2), 4-7 cells (4), 8-15 cells (8), 16-31 cells (16), 32 or more cells less than $2 \mathrm{~mm}$ in diameter (32), and colonies with a diameter of over $2 \mathrm{~mm}$. The colony number is expressed as a percentage of the number of basal cells plated in each dish (1023 for the slowly adhering cells and 690 for control).

b-f) Terminal differentiation of abortive (ie less than 32 cell) colonies.

Identical dishes to that shown in (a) were fixed at 3 hours (not shown), 24 hours and at 3, 5, 7 and 14 days and stained for involucrin, as a terminal differentiation marker, and keratins, as a marker of all keratinocytes. The number and size of abortive colonies were scored as for the 14 day dishes. Colonies were classified as to whether they contained cells which were all involucrin negative (open bars) both positive and negative (shaded bars), or all positive (black bars). 

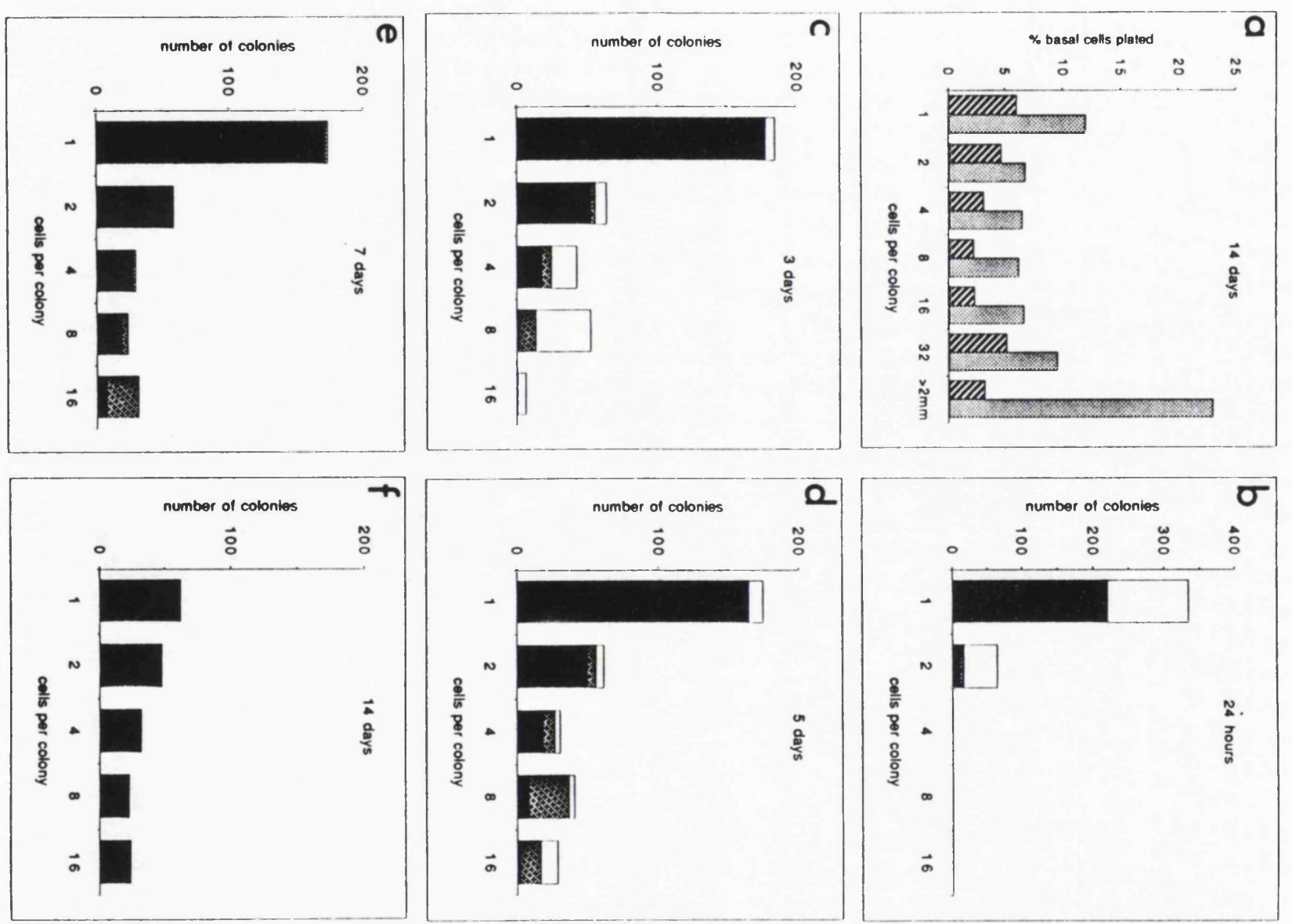


\section{CHAPTER 4 \\ EPidermal STem Cells in Vivo}

\section{INTRODUCTION}

The proliferative potential of a basal keratinocyte in vitro is related to its adhesiveness to ECM proteins. If the same relationship is present in vivo, it would allow the localisation of keratinocyte stem cells in vivo and the isolation of stem cells directly from the epidermis. There was some indirect evidence in support of keratinocyte stem cells being found in particular locations in the epidermis, especially within part of the hair follicle (see Chapter 1 for discussion). Hair follicle stem cells can be localised as they express keratin 19 (Stasiak, Purkis et al. 1989; Lane et al. 1991). However there are no reports of markers that identify interfolliclular stem cells or allow the isolation of viable stem cells from the epidermis.

Published studies of integrin expression in epidermal cells using indirect immunofluorescence had not looked for quantitative differences in integrin expression between basal cells in the epidermis (Peltonen, Larjava et al. 1989; De Luca, Tamura et al. 1990; Hertle, Adams et al. 1991). The difference in the level of integrin expression between stem cells and other basal cells in culture is only 2-3 fold (Chapter 3 and Jones and Watt, 1993). Indirect immunofluorescence techniques, involving a primary antibody and a secondary, fluorochrome conjugated antibody, are designed to maximise the signal from the primary antibody. Small but potentially relevant differences in integrin levels in tissue sections might be lost in the amplification of the primary antibody signal. I therefore labelled frozen sections of skin with anti-integrin antibodies which had been directly conjugated to fluorescein isothiocyanate (FITC), so that the fluorescence seen was in direct proportion to the number of antibody molecules bound at the cell surface.

Detecting small differences in fluorescence also required sections of epidermis of uniform thickness and an accurate method to quantify fluorescence. Both of these requirements were met by the use of a confocal microscope. This instrument can make thin $(1 \mu \mathrm{m})$ optical sections through tissue, thereby eliminating errors due to variations in thickness of histological sections. The image is captured digitally, 
allowing the quantitation of fluorescence intensity (White et al. 1987; Pawley and Centrose 1994).

Previous models of stem cells in the epidermis had assumed that in the steady state epidermal stem cells would be less likely to be in the cell cycle than transit amplifying cells (Holbrook and Hennings 1983; Potten and Morris 1988). The existence of stem and transit cells had been demonstrated in vitro and there was evidence that, in post confluent cultures, transit cells may indeed be more likely to be in $\mathbf{S}$ phase than stem cells (Chapter 3 ). If it were possible to localise stem cells in the epidermis it would be of interest to know their cell cycle status.

There are problems with applying the methods normally used to assess cell proliferation to human epidermis. Studies with tritiated thymidine have been performed in the past (Scheving 1959; Penneys, Fulton et al. 1970; Dover and Watt 1987) but would no longer be considered ethical. The same objection applies to in vivo injections bromodeoxyuridine (BRDU). Protein cell cycle markers are available, but little is known of how their expression is affected by cellular differentiation and other factors (Hall et al. 1990; Hall, Mckee et al. 1993). For example, proliferating cell nuclear antigen (PCNA) is induced by exposure of epidermis to ultraviolet light. The number of PCNA-positive cells rises whilst the mitotic index remains constant. I therefore opted to use in situ hybridisation for histone mRNA to detect $S$ phase cells. Cellular concentrations of histone mRNAs increase 20-100 fold during $S$ phase and rapidly decline in G2 (Heintz et al., 1983; Zhong et al., 1983; Harris et al., 1991). This method has been shown to correlate well with tritiated thymidine and BRDU pulse labelling in a variety of animal tissues including stratified squamous epithelia (Wong et al. 1990; Alison et al. 1994). I collaborated with Dr S Harper at Leicester General Hospital. Dr Harper carried out the in situ hybridisations and I analysed the results myself.

\section{RESULTS}

\section{Variation of integrin levels within the basal laver of the epidermis}

I began using the confocal microscope by examining sections of human epidermis stained with directly conjugated antibodies. Sections in which the plane of sectioning through the epidermis was not vertical, ie in which all cell borders of all basal cells could not be seen, were excluded from the analysis. 
Figure 4.1 shows how fluorescence levels were measured. Frozen sections of skin were labelled with FITC-conjugated antibodies to the $\alpha_{2}, \alpha_{3}, \alpha_{6}$ and $\beta_{1}$ integrin subunits. $\alpha_{5}$ was not examined because $\alpha_{5} \beta_{1}$ levels are very low or undectectable in mature, undamaged epidermis (Peltonen, Larjava et al. 1989; Hertle, Adams et al. 1991; Hertle, Kubler et al. 1992). The $\alpha_{6}$ subunit, which forms a heterodimer with $\beta_{4}$ and is a component of hemidesmosomes (Carter et al., 1990, Stepp et al., 1990), was included in the study because $\alpha_{6}$ levels are not correlated with proliferative potential in vitro (see Chapter 3, Jones and Watt, 1993). For the subunits of $\beta_{1}$ integrins, fluorescence was measured along a line drawn through the lateral borders of cells within the basal layer. Each cell-cell border appears as a peak of pixel intensity in arbitrary units on a linear scale (Figure 4.1). For the $\alpha_{6}$ subunit fluorescence was concentrated on the basal rather than the lateral or apical cell surfaces (Figure 4.2 D) and fluorescence was therefore measured across the basal surface of individual basal cells.

I examined skin from three body sites: neonatal foreskin, because this was the source of keratinocytes for the in vitro experiments descibed in Chapter 3; adult palm, because predictions about the location of epidermal stem cells in palm have been made from cell kinetic analysis (Lavker and Sun, 1982, 1983); and adult scalp, since the location of stem cells within hair follicles has been determined with some precision (Yang et al., 1993; Rochat et al., 1994). In epidermis from each site there was variation in the levels of the $\alpha_{2}$, and $\alpha_{3}$ integrin subunits (Figs. 4.1, 4.2, Table 4.1) but not in the level of the $\alpha_{6}$ subunit. (Figure 4.2D and Table 4.2). Although the specimens were studied using a confocal microscope, the variation in fluorescence levels was also seen using a conventional fluorescence microscope (eg. Fig. 4.2 E,F). In each site stained with antibodies to the $\alpha_{2}, \alpha_{3}$ or $\beta_{1}$ subunits integrin-bright basal cells had a non random distribution. Patches of brightly fluorescent basal cells were interspersed with stretches of basal cells of lower fluorescence.

The junction between the epidermis and underlying dermis undulates. Sites where the dermis comes closest to the skin surface are known as dermal papillae and sites where the epidermis projects furthest into the skin are known as rete ridges (Chacko and Vaidya 1968; Ham and Cormack 1979). In foreskin and scalp, rete ridges are relatively uniform in size, but in palm they have been classified as deep or shallow (Lavker and Sun, 1982, 1983). In foreskin (Fig. 2B) and interfollicular epidermis of scalp (Fig. 4.1, Fig. 4.2 C,E), the integrin-bright cells were found adjacent to the tips of the dermal papillae, whereas in palm (Fig. 4.2A) they were found at the tips 
of the deep rete ridges. In scalp a 'cuff of bright cells was also seen where hair follicles opened out onto the surface of the skin (Fig. 4.2F).

Table 4.1 presents quantification of the data for sections stained for the $\alpha_{2}$ or $\alpha_{3}$ integrin subunits. The proportion of brightly fluorescent cells in the basal layer was higher in foreskin and interfollicular scalp epidermis than in palm. The mean patch size for anti $\alpha_{2}$-stained foreskin was 14 cells, compared with 9 cells in scalp and palm (the difference was statistically significant, $P<0.001$, Mann-Whitney $U$ test). For anti- $\alpha_{3}$ stained sections, the mean patch size was 13 cells in foreskin and palm and 11 cells in scalp (this difference was not statistically significant). In foreskin the difference in the size of bright patches labelled with anti $\alpha_{2}$ or anti $\alpha_{3}$ antibodies was not significant; in palm and scalp the $\alpha_{3}$-bright patches were significantly larger than the $\alpha_{2}$-bright patches ( $\mathrm{P}=0.030$ and 0.0015 respectively, Mann-Whitney $\mathrm{U}$ test). Staining of serial sections with anti $\alpha_{2}$ and anti $\alpha_{3}$ antibodies showed that the $\alpha_{2}$ and $\alpha_{3}$-bright patches co-localised. In all sites and with both antibodies the variation in fluorescence intensity between 'bright' and 'dull' cells was approximately two-fold.

One region of the epidermis for which there is strong evidence for the location of stem cells is the hair follicle. In rodents, cells able to found keratinocyte colonies in vitro lie in a well defined bulge in the outer root sheath (Cotsarelis et al., 1990; Kobayashi et al., 1993). In humans the upper limit of the bulge is defined by the point of insertion of the arrector pili muscle, below which the outer root sheath broadens, but its lower limit is less clearly defined and the clonogenic cells are reported to be either close to the insertion of the muscle (Yang et al., 1993) or slightly below it (Rochat et al., 1994). Both regions of the human outer root sheath that are reported to contain clonogenic cells can be labelled with an antibody to keratin 19 (Stasiak, Purkis et al. 1989; Lane, Wilson et al. 1991; Narisawa et al. 1994). We therefore double labelled sections of scalp with antibodies to keratin 19 and the $\alpha_{2}$ or $\alpha_{3}$ integrin subunits (Fig. 4.2G). Keratin 19-positive outer root sheath cells had 1.4 ( \pm 0.1 standard error of the mean, SEM)-fold greater mean $\alpha_{2}$ and 1.6 ( \pm 0.1 SEM) -fold greater mean $\alpha_{3}$ integrin subunit fluorescence than keratin 19negative outer root sheath cells (both $P<0.001$, Mann-Whitney $U$ test). There was no significant difference in $\alpha_{6}$ integrin subunit fluorescence between keratin 19positive and -negative cells. 


\section{Isolation and cultivation of integrin-bright and -dull cells}

The criterion I used to define a stem cell in vitro was the ability to form a clone that is large enough to be seen under a dissecting microscope 14 days after plating. I used the same definition in experiments to determine whether or not the integrinbright population of cells isolated directly from the epidermis had high proliferative potential. Keratinocytes were isolated from foreskin epidermis and plated onto 100 $\mu \mathrm{g} / \mathrm{ml}$ type IV collagen for different lengths of time. Maximal attachment of freshly isolated basal keratinocytes occurred within $1 \mathrm{hr}$ (Fig. 4.3A), compared with 3-4 hours for keratinocytes maintained in culture through several passages (Adams and Watt, 1991). Adhesion of freshly isolated cells was mediated by the $\alpha_{2} \beta_{1}$ integrin, since it could be inhibited with antibodies to the $\alpha_{2}$ and $\beta_{1}$ subunits (Figure 4.4). Keratinocytes were distinguished from other epidermal cells such as melanocytes by staining with an anti-keratin antibody and basal keratinocytes were distinguished from suprabasal, differentiating cells by staining with an antibody to the $\beta_{1}$ integrin subunit (cf. Adams and Watt, 1991; Hertle et al., 1991).

The keratinocytes that adhered to type IV collagen, at a coating concentration of $100 \mu \mathrm{g} / \mathrm{ml}$, within 5 minutes were 28\% (mean; range 13-43\%) of basal cells and had a higher modal $\alpha_{2} \beta_{1}$ fluorescence than the total (unselected) basal population (Fig. 4.3B). We could therefore use rapid adhesion to collagen to isolate integrin-bright cells directly from the epidermis and examine the relationship between integrin levels and proliferative ability.

As shown in Fig. 4.3 C,D, most of the cells that founded actively growing colonies adhered to type IV collagen within $5 \mathrm{~min}$; the cells that took longer to adhere formed few colonies. The maximum CFE we obtained from cells that attached to $100 \mu \mathrm{g} / \mathrm{ml}$ type IV collagen within $5 \mathrm{~min}$ was $33 \%$ (mean $26 \pm 4.7 \%$ SEM, 4 experiments). By reducing the collagen concentration to $10 \mu \mathrm{g} / \mathrm{ml}$ we observed CFEs of up to $63 \%$ (mean $57 \pm 3 \%$ SEM, 3 experiments). However, whereas $77 \%$ $( \pm 10 \%$ SEM) of all colony forming cells attached to $100 \mu \mathrm{g} / \mathrm{ml}$ type IV collagen within $5 \mathrm{~min}, 40 \%$ ( $\pm 8 \% \mathrm{SEM}$ ) attached to $10 \mu \mathrm{g} / \mathrm{ml}$, the remainder being found in the more slowly adherent fractions. $100 \mu \mathrm{g} / \mathrm{ml}$ type IV collagen was therefore chosen for further experiments because it gave greater separation of colony-forming cells from other basal cells than the lower collagen concentration. These experiments show that the relationships between elevated $\beta_{1}$ integrin expression, enhanced adhesiveness and high proliferative potential that exist in cultured human 
keratinocytes (Chapter 3, Jones and Watt, 1993) also hold for keratinocytes isolated directly from the skin.

\section{Rapidly adhering keratinocytes are able to reconstitute an epidermis in vivo}

Keratinocytes selected by rapid adhesion to type IV collagen not only had high proliferative potential in vitro but were able to form a fully differentiated epidermis when grafted onto nude mice (Fig. 4.5, 4.6A). 14 confluent cultures generated by cells selected directly from 3 different foreskins were grafted onto mice and examined one week later. In 11 grafts an epithelium containing all four cell layers characteristic of epidermis (basal, spinous, granular and cornified) was formed (Fig $4.5,4.6 \mathrm{~A})$. In the remaining 3 cases no epithelium was recovered, and a dense inflammatory infiltrate surrounding amorphous eosinophilic material was seen.

\section{Stem cell patterning in epidermis grafted into nude mice}

I examined the grafted epidermis cultured from rapidly adherent primary keratinocytes to see if the basal keratinocytes had been able to reconstitute the pattern of integrin-bright and integrin-dullpatches in the absence of a human dermis. Sections were stained with the same directly conjugated antibodies to the $\alpha_{2}$ and $\alpha_{3}$ integrin subunits that had been used to stain the sections of normal human epidermis shown in Figures 4.1 and 4.2. When viewed on the confocal microscope integrin bright and dull patches were clearly seen for both subunits (Figure 4.7B and data not shown).

\section{The fate of slowly adhering basal cells}

The fate of individual keratinocytes isolated from foreskin epidermis was also examined and the results of one experiment are shown in Figure 4.7. I had previously defined committed cells as cells that undergo terminal differentiation without dividing and transit amplifying cells as those that form small ( $<32$ cell) colonies of differentiating cells by 14 days in culture (see chapter 3, Jones and Watt, 1993). Dishes of cells that had adhered to type IV collagen within $5 \mathrm{~min}$ or that took longer than $5 \mathrm{~min}$ to adhere were fixed at intervals between 3 hours and 14 days. All adherent keratinocytes were visualised by staining with a broad spectrum anti-keratin antibody and cells that were undergoing terminal differentiation were detected with an anti-involucrin antibody. Almost all the single cells that originally attached had either divided or differentiated by day 5 and many of the differentiated 
cells had detached from the dishes. At day 5 the number of colonies containing between 8 and 31 cells that were completely involucrin-negative, provided an accurate prediction of the number of large ( 232 cell) colonies at 14 days; the final CFEs were $16.5 \%$ for the rapidly adhering cells and $4.4 \%$ for the remaining basal cells. By day 14 the majority of colonies with less than 16 cells were entirely involucrin-positive in each population. The data show that both rapidly and slowly adhering populations contained transit amplifying and committed cells, but that the proportion was higher in the slowly adherent population.

\section{Cell cycle kinetics of basal keratinocytes}

I examined the proliferative status of basal keratinocytes in different body sites to see if the proportion of actively cycling basal keratinocytes in integrin-bright regions was lower than the proportion in integrin-dull regions as predicted. Cells in $S$ phase of the cell cycle were located by in situ hybridisation with a cocktail of deoxyoligonucleotide probes to histone $\mathrm{H} 2 \mathrm{~b}, \mathrm{H} 3$ and $\mathrm{H} 4$ mRNAs. In situ hybridisations were carried out by Dr $S$ Harper, Dept of Nephrology, Leicester General Hospital, Leicester. I analysed all the sections myself.

Figure 4.8 shows the results of controls. Several negative controls were performed on different specimens from each site. Four controls were used for the hybridisation step. RNAse A1 pretreatment was used to degrade RNA. The probe was omitted altogether. A digoxigenin labelled random 30 base oligonucleotide cocktail was used in the place of the histone probes. Finally a digoxigenin labelled non homologous probe cocktail to immunoglobulin kappa light chain mRNA, containing nine deoxyoligoprobes all 30 bases in length with the same guaninecytosine content as the histone cocktail (55\%), was substituted for the histone probes. As a contol for non specific antibody binding, the alkaline phosphatase reaction was performed with no antidigoxigenin antibody. No postively stained cells were seen with any negative control (Figure 4.8A).

As a positive control scalp sections containing the matrix region of hair follicles were examined. This region is known to have high mitotic activity in the anagen phase of the hair cycle (Weinstein and Mooney 1980; Ebling et al. 1991). There were numerous histone positive cells in the matrix of anagen follicles (Figure 4.8B). 
When sections of palm, foreskin and interfollicular scalp epidermis that had been hybridised with the histone probe were analysed, the areas corresponding to integrin-dull regions of the basal layer were found to contain a significantly higher proportion of $S$ phase cells than the integrin-bright regions. Thus in palm more $S$ phase cells were found at the tips of the dermal papillae and sides of rete ridges, whereas in scalp and foreskin there were more $S$ phase cells at the tips of the rete ridges (Fig. 4.9, Table 4.2).

\section{Discussion}

I was able to determine the location of epidermal stem cells in the basal layer of the epidermis in vivo as the relationship between integrin expression and function described in vitro also exists in vivo. When a single cell suspension of keratinocytes was prepared directly from the skin it was possible to isolate the cells that were capable of founding actively growing colonies by selecting for high surface expression of the $\alpha_{2} \beta_{1}$ integrin and rapid adhesion to type IV collagen. The cells with the highest levels of $\alpha_{2} \beta_{1}$ also expressed the highest levels of $\alpha_{3} \beta_{1}$, as had been seen in vitro. Also, just as with cultured keratinocytes, expression of $\alpha_{6} \beta_{4}$ did not correlate with proliferative potential. The keratinocytes isolated directly from the epidermis that had lower levels of $\alpha_{2} \beta_{1}$ and adhered more slowly to type IV collagen had characteristics of transit amplifying cells and committed cells, undergoing terminal differentiation within a few rounds of division. The differences in integrin levels that were significant in vivo were the same as in vitro (2-3 fold). The maximum enrichment for colony forming cells within the integrinbright population was $63 \%$ (range $52-63 \%$ ), which is comparable with the CFE of keratinocytes dissected from a region of the hair follicle enriched for stem cells (1845\%; Rochat et al., 1994).

About $40 \%$ of cells in the basal layer of the epidermis are integrin-bright, yet kinetic analysis would predict that the percentage of stem cells is closer to $10 \%$ (Potten and Morris, 1988) and the CFE of unselected basal cells in our experiments was $9.5 \%( \pm 2.3 \%$ SEM). Although the integrin-bright population of basal cells contained almost all the stem cells, it also contained some transit amplifying cells (see Fig. 4.3). Quantitative differences in integrin expression alone did not provide a $100 \%$ specific means to identify stem cells. Nevertheless, integrins are the first known surface markers of epidermal stem cells and confocal microscopy of epidermal sections with fluorochrome-conjugated antibodies to other antigens will provide a rapid and sensitive screen for additional markers. 
Integrin-bright cells within the epidermis were arranged in groups, 9-14 cells in diameter, indicating a clustering of stem cells within the basal epidermal layer. In mouse dorsal skin there are morphological and kinetic data to support the 'Epidermal Proliferative Unit' (EPU) model of Potten (1974) in which a single stem cell lies at the base of a column of suprabasal cells and is surrounded by transit amplifying and committed cells. In the EPU, suprabasal terminally differentiating keratinocytes are the progeny of the stem cells directly beneath them. In contrast, the clustering of stem cells we have observed suggests that in human epidermis there is extensive lateral cell movement (see Figure 4.10 and also Lavker and Sun, 1983).

The distribution of integrin-bright and -dull cells in sections of epidermis from different body sites was not random. Integrin-bright cells lay above the dermal papillae in foreskin and interfollicular scalp (and in breast and abdominal skin; data not shown) but were found at the tips of the deep rete ridges in palm. Cell kinetic data suggest that although epidermal stem cells have high proliferative potential, they may divide only rarely under normal steady state conditions (Potten and Morris, 1988; Cotsarelis et al., 1989, 1990) and in the three body sites I examined there were fewer $S$ phase cells in the regions of the basal layer where integrin-bright cells were found. Indeed, the location of stem cells in the deep rete ridges of the palm was previously suggested by the fact that few of these cells incorporate ${ }^{3} \mathrm{H}$ thymidine in pulse labelling experiments (Lavker and Sun, 1982, 1983). It is interesting that in palm, the morphology of basal keratinocytes differs between deep and shallow rete ridges (Lavker and Sun, 1982, 1983) as does the subcellular distribution of $\alpha_{3} \beta_{1}$, which is relatively less abundant on the apical surface of cells in the deep rete ridges and on the basal surface of cells in the shallow ridges (Symington et al., 1993, and see Figure 4.2A).

In human hair follicles, keratinocytes with high proliferative potential are reported to lie in the outer root sheath, either at the point of insertion of the arrector pili muscle (Yang et al., 1993), or lower down (Rochat et al., 1994). Both regions can be labelled with an antibody to keratin 19 (Stasiak et al., 1989; Lane et al., 1991). Keratin 19-positive outer root sheath cells expressed higher levels of $\alpha_{2} \beta_{1}$ and $\alpha_{3} \beta_{1}$ than keratin 19-negative cells. The fact that the difference in fluorescence (1.4-1.6 fold) was lower than observed in interfollicular epidermis (approximately 2 fold) would be consistent with only a subset of keratin 19-positive cells being stem cells. Staining longitudual sections of hair follicles with anti integrin antibodies may help to determine the location of the stem cells more precisely. 
That the stem cells, which are the only basal keratinocytes to persist throughout adult life, should be the cells that were most adhesive to the epidermal basement membrane is perhaps unsurprising. However, the highly patterned distribution of stem cells in the interfollicular epidermis is intriguing. Keratinocytes grafted into nude mice and cultured in contact with the reticular dermis were able to reconstitute the pattern of alternating integrin-bright and dull-patches seen in human epidermis. It follows that the presence of human papillary dermis with its architecture of dermal papillae and rete ridges is not essential for pattern formation (see Chapter 7 for further discussion).

Cell fate patterning has been intensively studied in developmental models but not in adult human epithelia. The next chapter explores the mechanisms involved in the production and regulation of epidermal stem cell patterning. 
Table 4.1: Integrin expression in basal cells in different body sites

\begin{tabular}{|c|c|c|c|}
\hline$\alpha_{2}$ subunit & Foreskin & Scalp & Palm \\
\hline \% bright cells & $43 \pm 1.7$ & $39 \pm 1.4$ & $25 \pm 2.2$ \\
\hline patch size & $14 \pm 1.4$ & $8.7 \pm 0.5$ & $8.7 \pm 0.7$ \\
\hline intensity ratio & $2.1 \pm 0.1$ & $2.2 \pm 0.3$ & $1.8 \pm 0.1$ \\
\hline
\end{tabular}

\begin{tabular}{|c|c|c|c|}
\hline$\alpha_{3}$ subunit & Foreskin & Scalp & Palm \\
\hline \% bright cells & $44 \pm 1.4$ & $48 \pm 2.5$ & $25 \pm 1.2$ \\
\hline patch size & $13 \pm 1.5$ & $11 \pm 0.7$ & $13 \pm 0.8$ \\
\hline intensity ratio & $2.1 \pm 0.2$ & $2.0 \pm 0.2$ & $1.9 \pm 0.1$ \\
\hline
\end{tabular}

Values are means \pm SEM.

$\%$ bright cells : \% of all basal cells with high integrin fluorescence.

Patch size: number of cells in each integrin-bright patch.

Intensity ratio: ratio of average fluorescence of cell- cell borders in bright patches to average fluorescence of cell- cell borders in dull patches. 


\section{Table 4.2: Expression of the $\alpha_{6}$ integrin subunit}

The $\alpha_{6}$ subunit appears evenly distributed along the basal surface of basal keratinocytes at each body site examined. To confirm this impression the fluorescence on the basal surface of 100 cells was measured in 4 specimens at each body site. The mean $\alpha_{6}$ subunit fluorescence of the cells lying in regions corresponding to the $\alpha_{2}$ and $\alpha_{3}$ integrin-bright patches (ie overlying the dermal papillae in scalp and foreskin and at the tips of the deep rete ridges in palm) is shown, expressed as a ratio of the mean fluorescence of cells in areas corresponding to $\alpha_{2}$ and $\alpha_{3}$ integrin-dull patches. In each case the ratios are not significantly different from 1.

\begin{tabular}{|c|c|}
\hline Site & $\begin{array}{c}\text { Ratio of mean } \alpha_{6} \\
\text { fuorescence }( \pm \text { SEM) }\end{array}$ \\
\hline Foreskin & $1.08 \pm 0.11$ \\
\hline Scalp & $1.05 \pm 0.07$ \\
\hline Palm & $1.01 \pm 0.06$ \\
\hline
\end{tabular}


Table 4.3: Distribution of $S$ phase cells in the basal epidermal layer as determined by in situ hybridisation with histone probes

\begin{tabular}{|c|c|c|c|c|c|}
\hline Tissue & $\begin{array}{c}\text { Integrin- } \\
\text { bright }^{2}\end{array}$ & Integrin-dull & $\begin{array}{c}\text { Combined } \\
\text { ratio }^{3}\end{array}$ & $\begin{array}{c}95 \% \\
\text { confidence } \\
\text { interval }\end{array}$ & $\mathrm{P}^{3}$ \\
\hline Foreskin (4) & 7.1 & 10.9 & 1.27 & $1.10-1.48$ & 0.001 \\
\hline Scalp (3) & 1.9 & 5.4 & 2.97 & $1.43-6.15$ & 0.003 \\
\hline Palm (4) & 0.78 & 2.2 & 4.00 & $2.00-7.69$ & $<0.0001$ \\
\hline
\end{tabular}

${ }^{1}$ Number of specimens examined is shown in brackets

$2 \%$ basal cells in $S$ phase (typical specimen from each site), in $\alpha_{2}$ subunit bright and $\alpha_{2}$ subunit dull patches.

${ }^{3}$ Ratio of S phase cells in integrin-dull: integrin-bright patches (combined values from all specimens).

Combined ratios, confidence intervals and P values calculated using method of Greenland and Robins (1985). 
FIGURE 4.1: Quantification of integrin levels by confocal microscopy

A) Section of human scalp stained with FITC-conjugated antibody to $\alpha_{3}$ integrin subunit. B) Fluorescence (on the $y$ axis, pixel intensity is in arbitrary units, linear scale) was measured along lines drawn through individual cells, each numbered peak corresponding to one numbered cell-cell border. $x$ axis represents distance along the basal layer in $\mu \mathrm{m}$. 1-4: brightly stained cells at tip of dermal papilla. 5-8: weakly stained cells at tip of rete ridge. Mean fluorescence of cell-cell borders is 105 units $(1-4)$ and 42 units (5-8). 


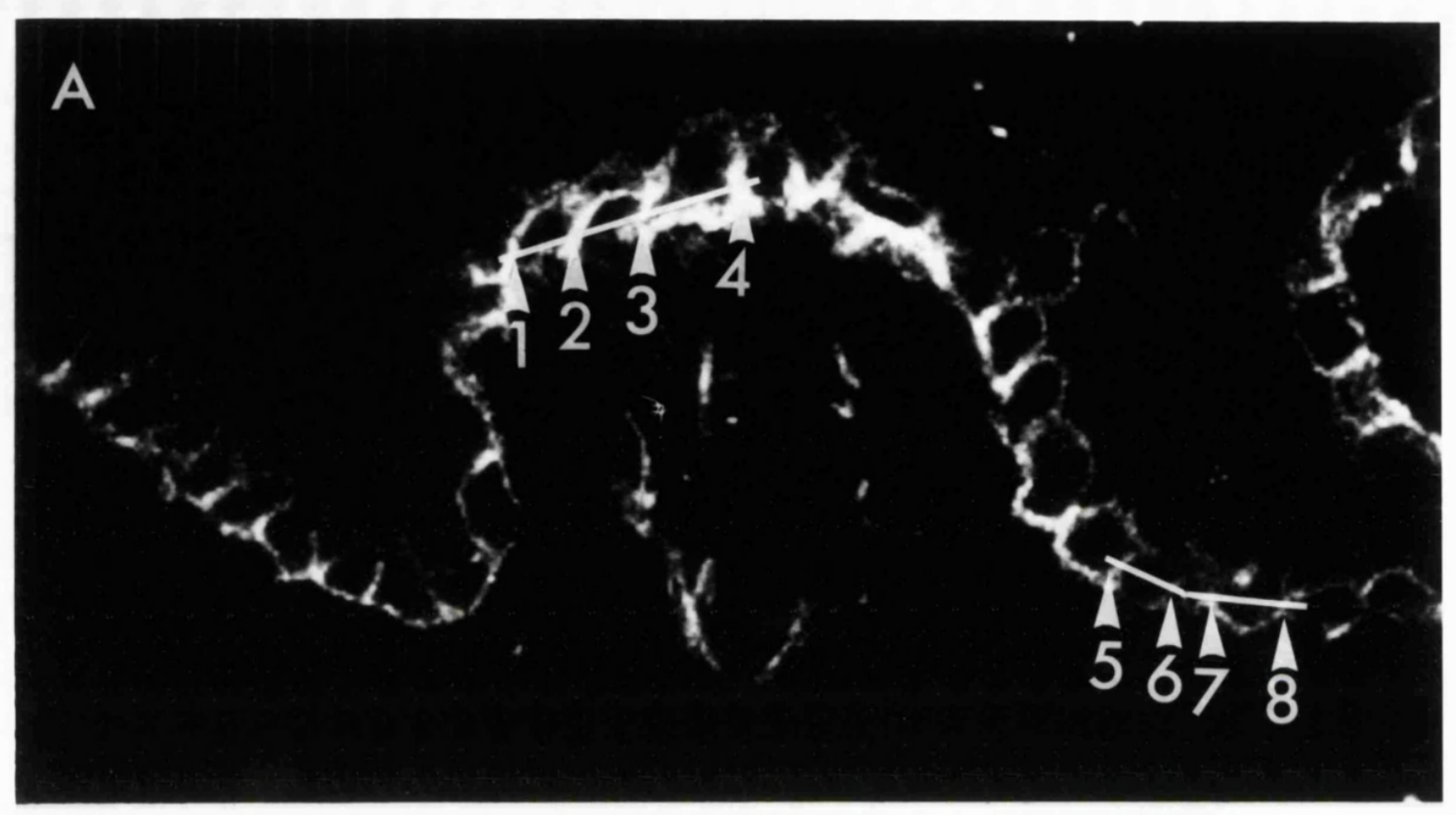

B
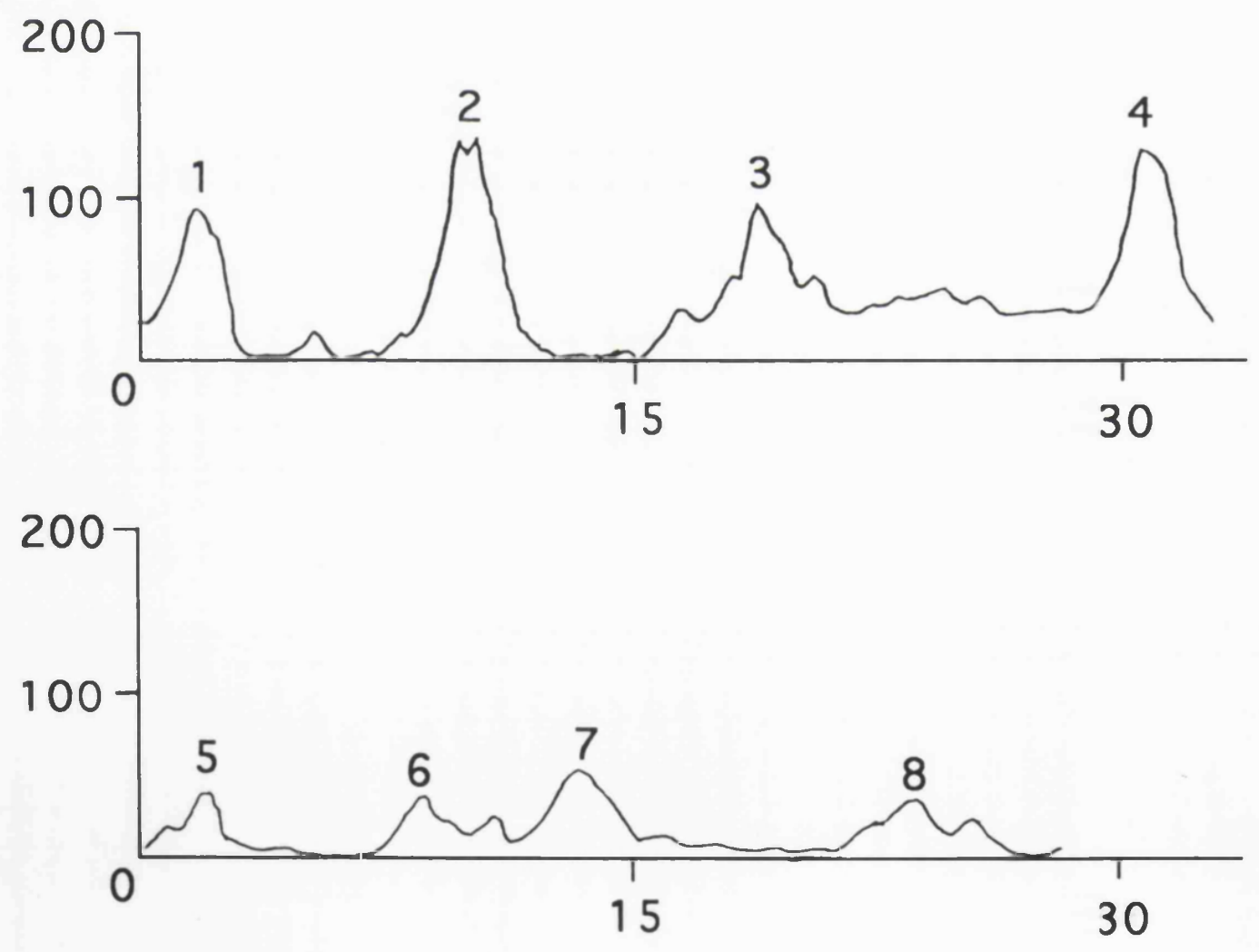
FIGURE 4.2: Variation in integrin levels in human skin from different body sites

Frozen sections were stained with FITC-conjugated antibodies to the integrin subunits indicated were viewed by confocal $(A-D, G)$ or conventional $(E, F)$ microscopy.
A) palm, $\alpha_{3}$ subunit;
B) foreskin, $\alpha_{3}$ subunit;
C) interfollicular scalp, $\alpha_{3}$ subunit;
D) palm, $\alpha_{6}$ subunit;
E) interfollicular scalp, $\alpha_{2}$ subunit;
F) scalp, including hair follicle, $\alpha_{2}$ subunit;
G) hair follicle outer root sheath double labelled with an FITC-conjugated antibody to the $\alpha_{3}$ integrin subunit (left panel) and an antibody to keratin 19 visualised with a rhodamine-conjugated second antibody (right panel). Scale bars $=50 \mu \mathrm{m}$. 


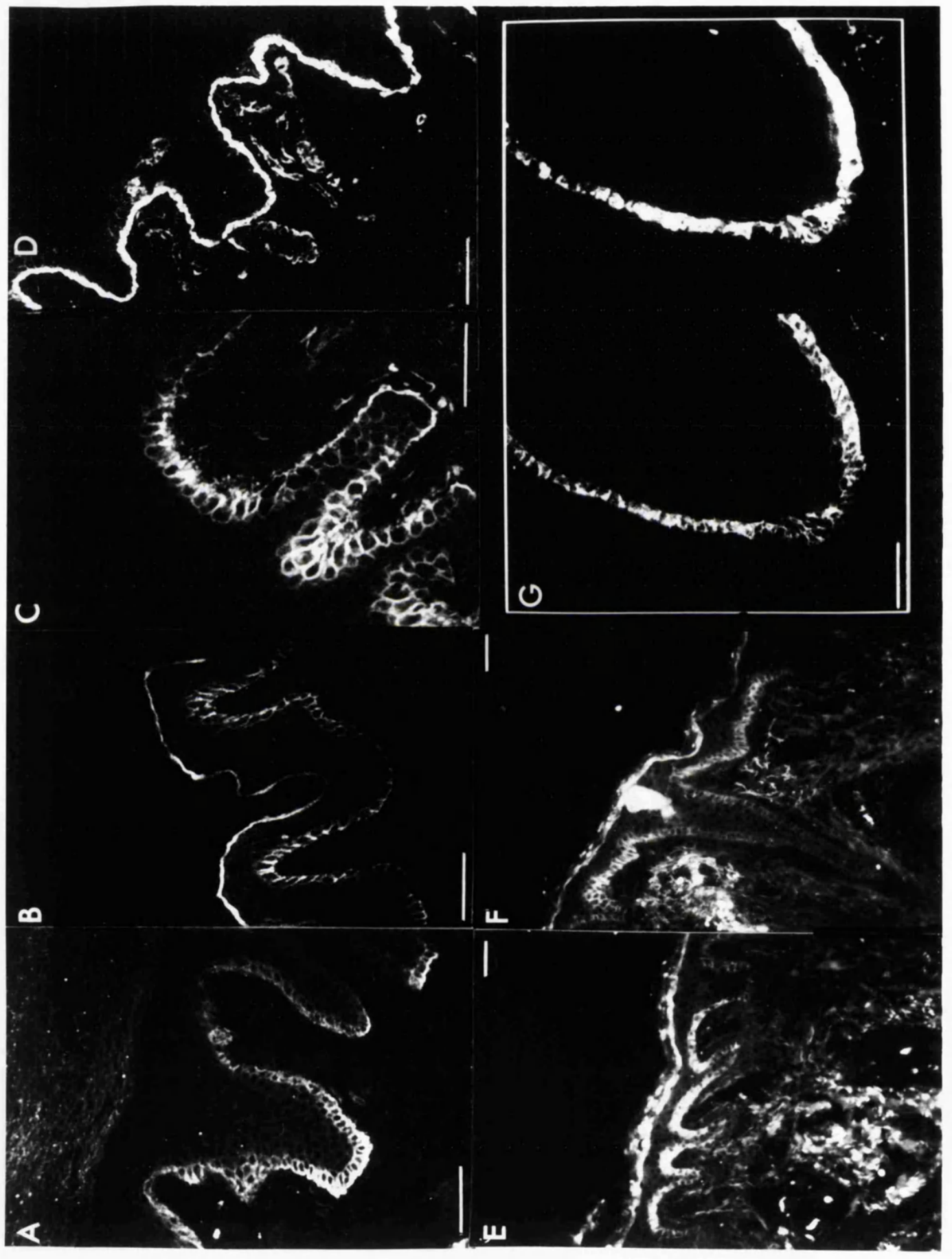


FIGURE 4.3: Relationship between integrin expression and CFE in keratinocytes isolated directly from neonatal foreskins

A) Freshly isolated cells were plated onto dishes coated with $100 \mu \mathrm{g} / \mathrm{ml}$ type IV collagen for different lengths of time. The graph shows the percentage of basal cells that attached against time after plating. A typical example of 3 experiments is shown.

B) Keratinocytes were labelled with an FITC-conjugated antibody to the $\alpha_{2}$ integrin subunit and analysed by flow cytometry. Fluorescence (in arbitrary units on a log scale) is shown on the $x$ axis and cell number on the $y$ axis. Dashed line : total keratinocyte population; solid line : cells that adhered to $100 \mu \mathrm{g} / \mathrm{ml}$ type IV collagen within 5 minutes. The marker on the $x$ axis shows the upper limit of fluorescence of a control antibody (CD8-FITC). The double peak in the total population comprises suprabasal, integrin-negative cells (left hand peak) and basal, integrin-positive cells (right hand peak).

C) Keratinocytes were plated onto $100 \mu \mathrm{g} / \mathrm{ml}$ type IV collagen for 5 minutes (0-5) or 20 minutes (0-20), and the nonadherent cells were then transferred to fresh collagencoated dishes (5+ and 20+ respectively) and allowed to attach overnight. After 14 days in culture all colonies larger than 32 cells in size were counted, and the CFE of each population was calculated and expressed relative to that of unfractionated basal cells $(=1.0)$. Results shown are the means of 3 experiments; error bars show the standard error of the mean. Cells which adhered within $5 \mathrm{~min}$ had a significantly higher CFE than those that adhered more slowly ( $p=0.007$, Student's $t-T e s t)$.

D) Colonies from one experiment performed as described in C), visualised by staining for involucrin and keratins. Left hand dish : colonies formed by cells that adhered to type IV collagen in $5 \mathrm{~min}$; centre dish : cells adhering after 5 minutes; right hand dish : unfractionated cells. Scale bar $=1 \mathrm{~cm}$. 


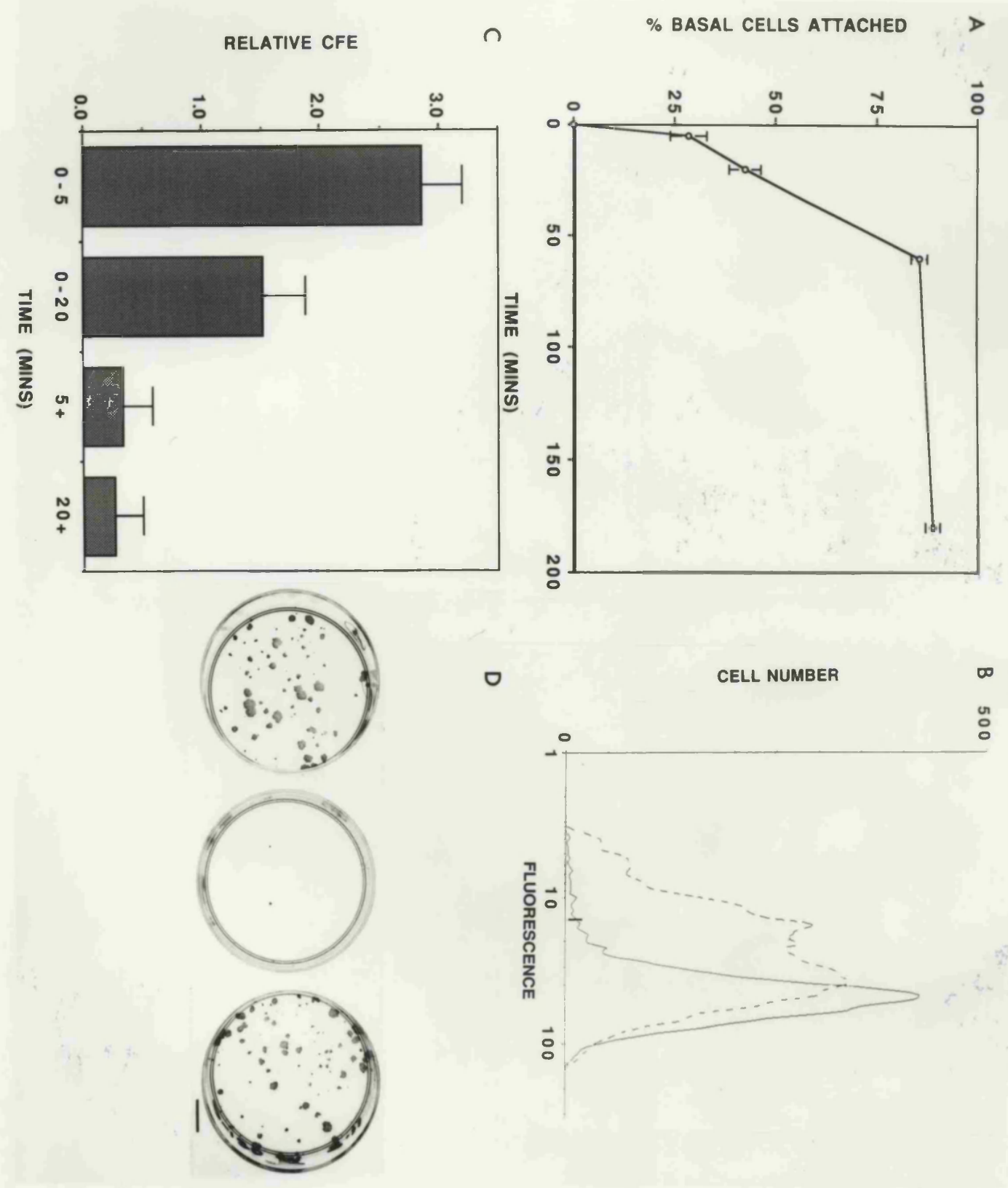


FIGURE 4.4: Blocking adhesion of freshly isolated foreskin keratinocytes to type IV collagen with anti integrin antibodies

Freshly isolated neonatal foreskin keratinocytes were plated onto 96 well plates coated with $100 \mu \mathrm{g} / \mathrm{ml}$ type IV collagen, in serum free FAD medium for 1 hour, at $37^{\circ} \mathrm{C}$, in the presence of the following anti integrin antibodies, used at the concentrations given:

DH12: anti $\beta_{1}$ subunit $200 \mu \mathrm{g} / \mathrm{ml}$, adhesion neutral (Hotchin, Kovach et al. 1993).

mAb 13: anti $\beta_{1}$ subunit, $200 \mu \mathrm{g} / \mathrm{ml}$, adhesion blocking (Larjava, Peltonen et al. 1990; Adams and Watt 1991).

HAS6: anti $\alpha_{2}$ subunit, $100 \mu \mathrm{g} / \mathrm{ml}$, adhesion blocking (Tenchini, Adams et al. 1993).

5E8: anti $\alpha_{2}$ subunit, 100 fold dilution of ascites, adhesion blocking (Adams and Watt 1991).

The number of cells attaching is expressed as a percentage of the number of cells that attached in the absence of antibody (Nil). 


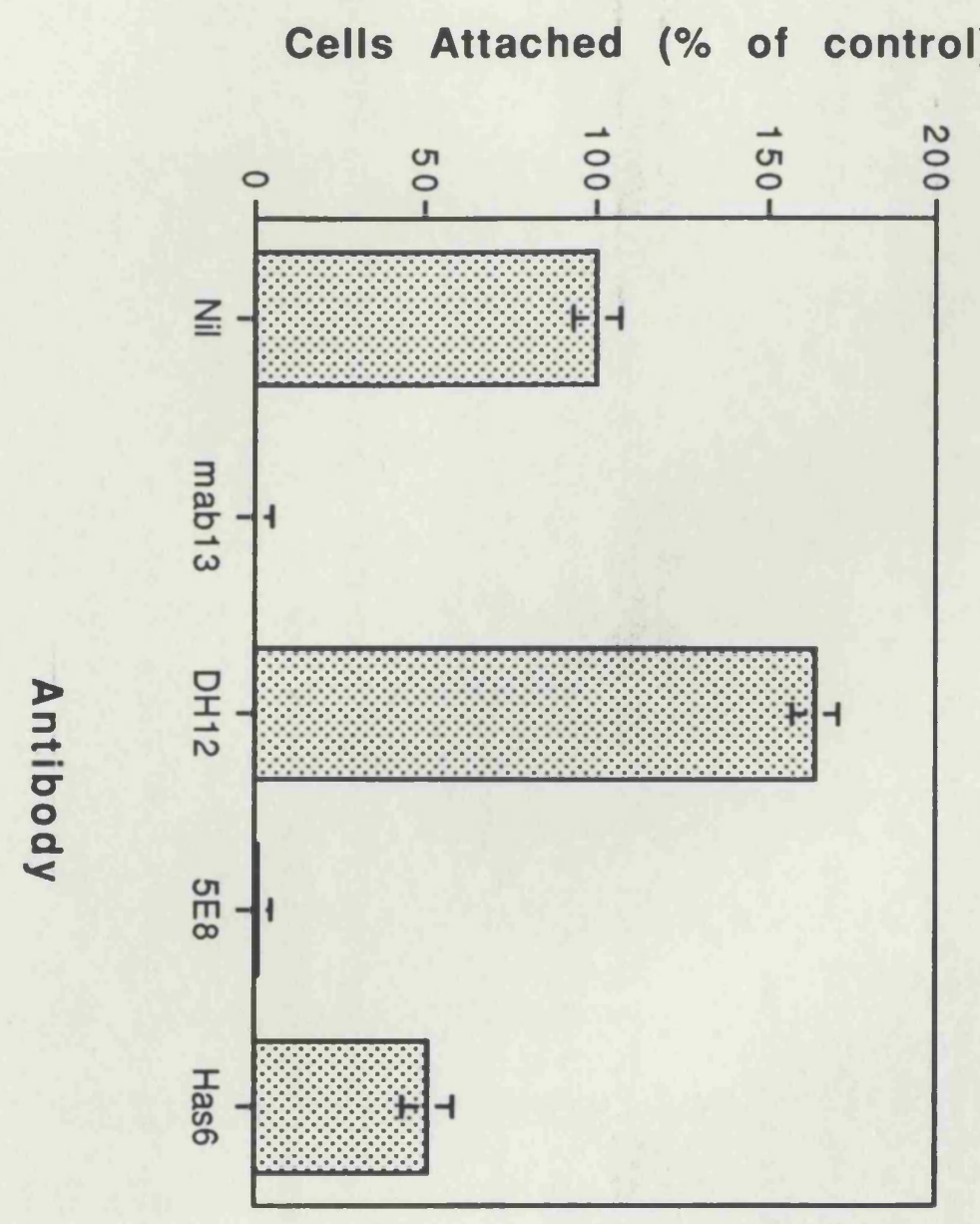


FIGURE 4.5: Grafting of rapidly adherent cells onto nude mice

Freshly isolated cells that adhered within 5 minutes to collagen type IV were cultured until they formed a confluent sheet. The cultured epidermis was removed from the dish with dispase and inserted under a subcutaneous flap on a nude mouse. After 1 week the animals were sacrificed and the grafts examined. The appearance of haematoxylin and eosin stained sections is shown. 11 of 14 mice grafted had a similar epidermis.

A) Appearance of graft: a, mouse dermis; b, mouse subcutaneous connective tissue including hair follicles; $c$ mouse panniculus carnosus; $d$, mouse deep fascia; $e$, human epidermis.

B) and C), appearance of epidermis formed by rapidly adherent cells. Basal, spinous, granular and cornified layers can be seen.

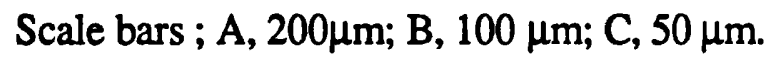



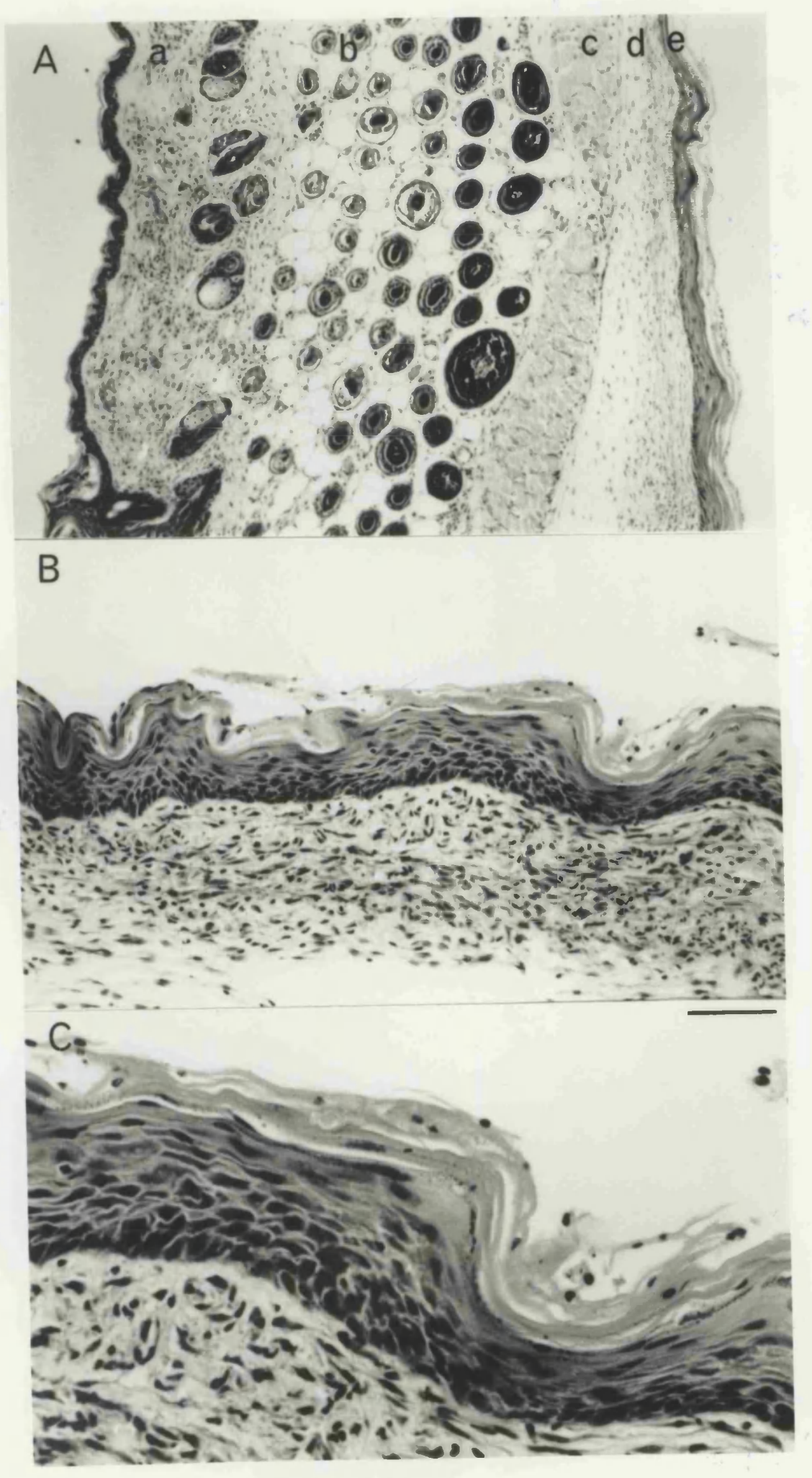
FIGURE 4.6: Rapidly adherent cells reconstitute epidermis in nude mice

\begin{abstract}
A) Haematoxylin and eosin stained section of epidermis formed by rapidly adhering cells in nude mice, as described in Figure 4.6.
\end{abstract}

B) Section of grafted epidermis stained for the anti $\alpha_{2}$ integrin subunit with HAS6FITC antibody, viewed at low power on the confocal microscope: The colour indicates the intensity of fluorescence, increasing from blue to magenta on a linear scale.

Scale bar: $45 \mu \mathrm{m}(\mathrm{A}), 100 \mu \mathrm{m}$ (B) 


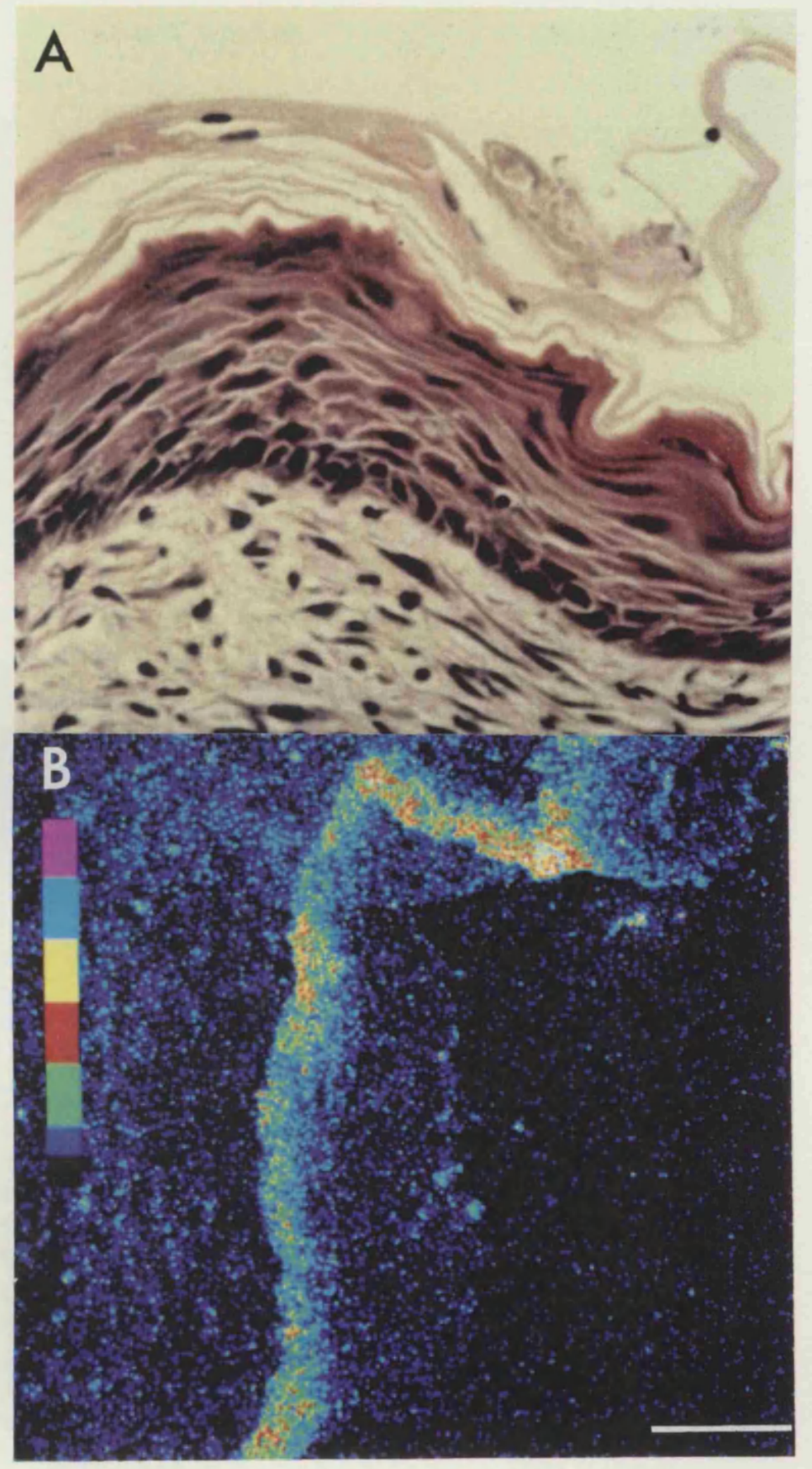


FIGURE 4 .7: Fate of individual cells isolated from foreskin epidermis.

Keratinocytes that adhered to $100 \mu \mathrm{g} / \mathrm{ml}$ type IV collagen within 5 minutes (0-5 MINS) were compared with the remaining basal keratinocytes (5+ MINS). The graphs show the number of cells per colony, 1-14 days after plating. White bars : all cells per colony were involucrin-negative; black bars : all cells were involucrinpositive; hatched bars : mixture of involucrin-positive and involucrin-negative cells. The $y$ axis shows colony number expressed as a percentage of the basal cells seeded per dish. 
0-5 MINS
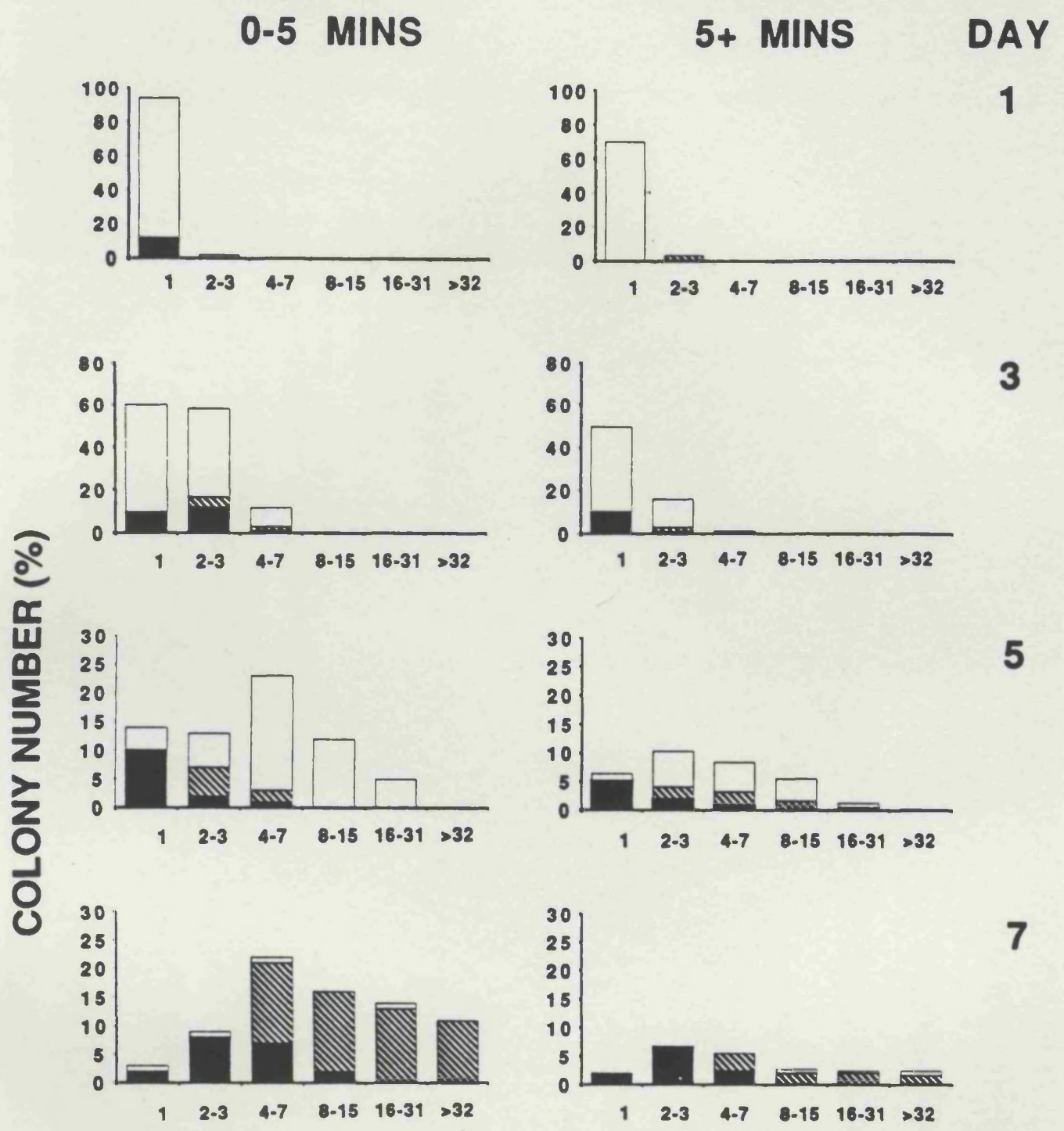

5

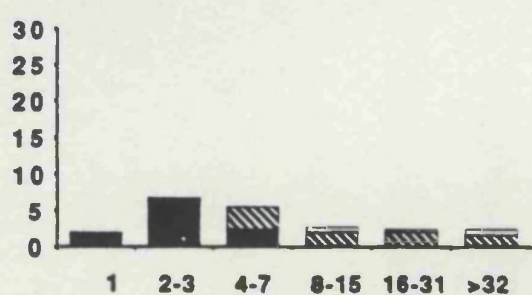

7
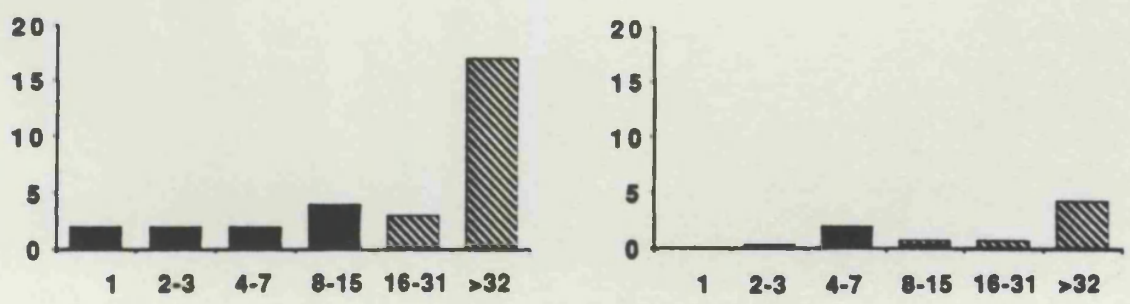
FIGURE 4.8: In situ hybridisation controls

\begin{abstract}
A) In situ hybridisation of human neonatal foreskin epidermis using a cocktail of 9 deoxyoligonucleotide probes to immunoglobulin mRNA. Each probe is of the same length and \% guanine and cytidine content as the probes used for histone mRNA. No positively stained cells were seen. Other negative controls had an identical appearance.
\end{abstract}

B) In situ hybridisation of human scalp epidermis with deoxyoligonucleotide probe to mRNA for histones 2-B, 3 and 4. The bulb region of an anagen hair follicle is shown. Numerous positive cells are seen.

Scale bar : $100 \mu \mathrm{m}$ 


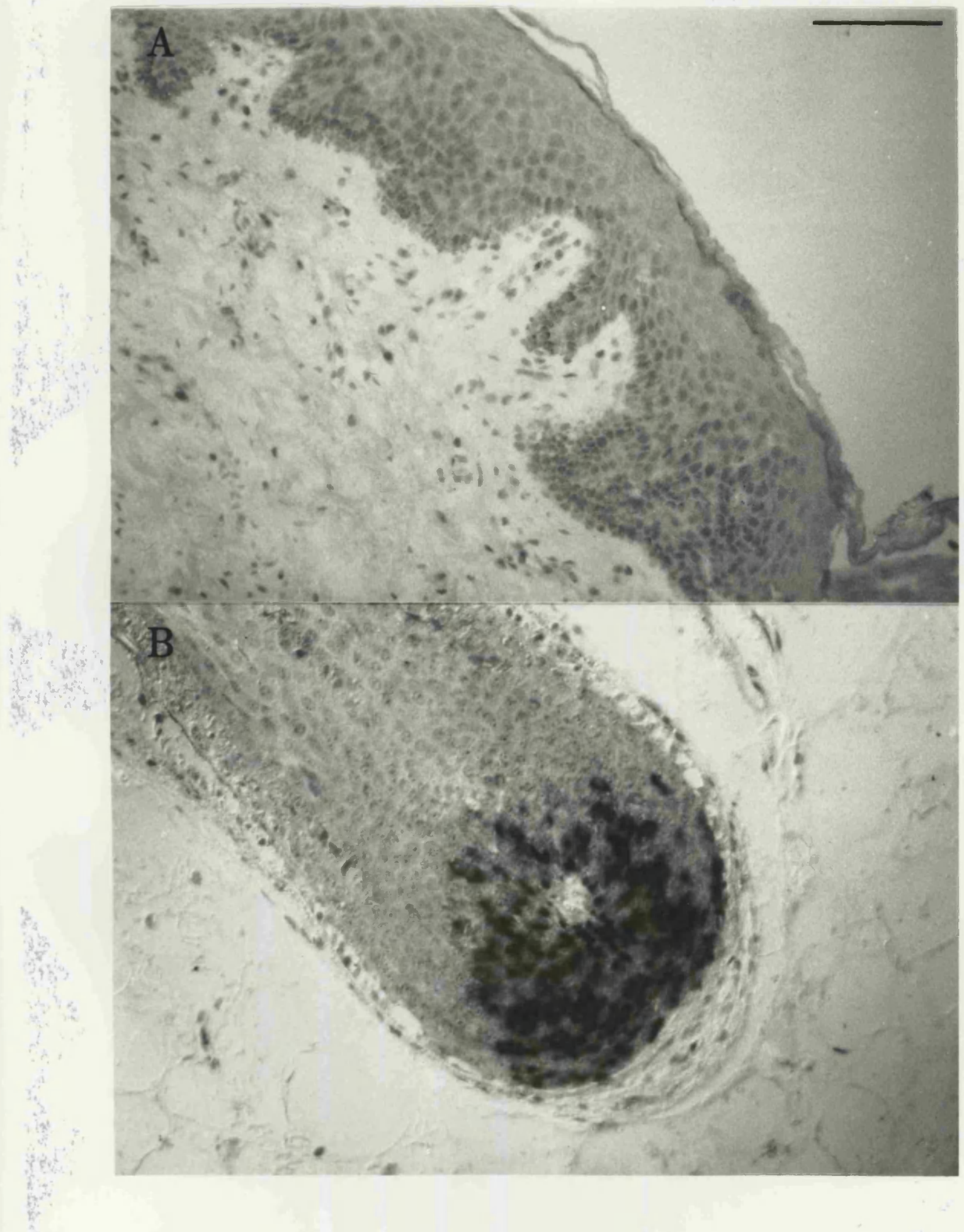


FIGURE 4.9: Distribution of $S$ phase cells within the epidermis

In situ hybridisation using deoxyoligonucleotide probes against mRNAs for histones 2-B, 3 and 4 on paraffin sections of epidermis.

A) Neonatal foreskin. Open arrows define group of cells at the tip of a dermal papilla, corresponding to the size and location of an 'integrin bright' patch (see Table 1).

B) Interfollicular scalp. Arrow indicates group of $S$ phase cells.

C) Palm. Arrows indicate individual $S$ phase cells.

Scale bars: $25 \mu \mathrm{m}(A), 50 \mu \mathrm{m}(B, C)$. 





FIGURE 4.10: Implications of stem cell patterning for cell migration in the epidermis

The patterned distribution of stem cells suggests that extensive lateral cell migration is occuring in the epidermis, probably in both basal and suprabasal layers, perhaps as shown here. 


\section{SCALP}
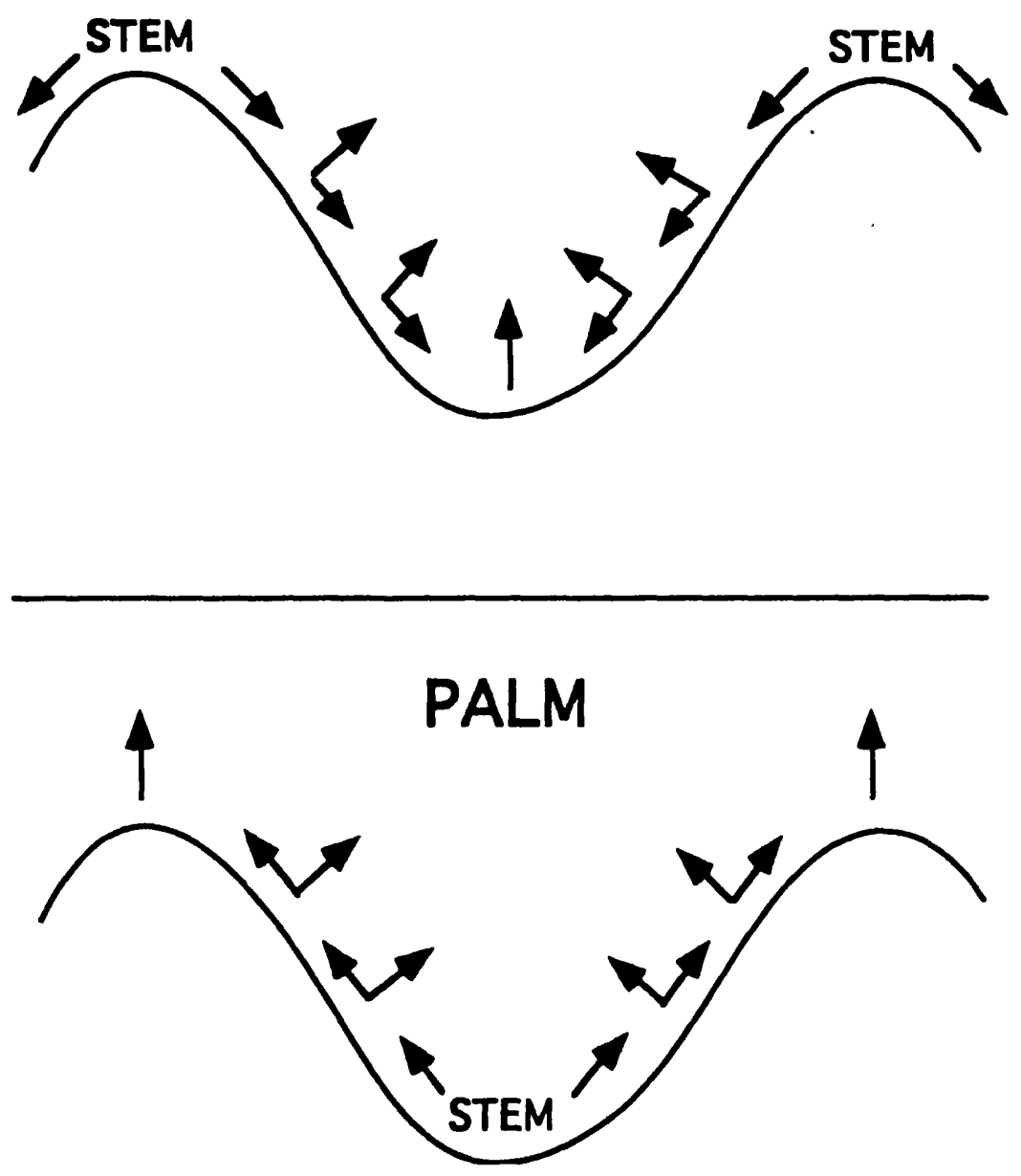


\section{CHAPTER 5 \\ Stem Cell Fate and Patterning}

\section{INTRODUCTION}

Stem cells are found in a highly patterned distribution within the epidermis (see Chapter 4). Such patterning may arise from interaction of keratinocytes with the underlying dermis, interactions between keratinocytes themselves, or a combination of both mechanisms. Stem cell patterning was found in epidermis grafted into nude mice, so is neither dependent on the presence of human dermis, nor on contact with papillary dermis. This raised the question as to whether patterning could be reconstituted by keratinocytes cultured in vitro on a feeder layer of 3T3 cells.

As discussed in Chapter 1, the mechanisms governing the cell fate decisions of keratinocyte stem cells and their progeny are unclear. I will describe the preliminary results of an approach to study keratinocyte stem cell fate using dye dilution.

\section{RESULTS}

\section{Reconstitution of Stem Cell Patterning in vitro}

I investigated whether or not patches of integrin-bright and -dull cells formed in confluent stratified sheets of keratinocytes cultured on plastic in the absence of dermis. Cells were isolated from foreskin and passaged at least once before use. I examined cultures prepared from keratinocytes enriched for stem cells, selected by adhesion to $100 \mu \mathrm{g} / \mathrm{ml}$ type IV collagen for $20 \mathrm{~min}$, as described previously (see Chapter 3 and Jones and Watt, 1993) and unselected keratinocytes. Intact sheets were detached from the plastic using Dispase (Boehringer Mannheim) and either sectioned prior to staining with FITC-conjugated anti-integrin antibodies (Figures $5.1 \mathrm{~A}$ and B) or stained as whole mounts (Fig. 5.1 C). Labelling with antibodies to the $\alpha_{2}$ or $\alpha_{3}$ integrin subunits revealed patches of integrin-bright cells whether the sheets were generated by an unselected cell population or by rapidly adherent cells (Figure. 5.1, Table 5.1). The variation in fluorescence intensity was similar to that observed in vivo (see Table 5.1): the ratios of mean fluorescence intensity of cells in the bright patches to cells in the dull patches were 1.7 ( \pm 0.04 SEM) and 1.9 ( \pm 0.09 SEM) for the $\alpha_{2}$ and $\alpha_{3}$ integrin subunits respectively. The presence of dermis is not required for pattern formation.

Is it possible to vary the pattern of bright and dull patches by using different keratinocyte subpopulations to establish the culture? I set up cultures with unselected 
keratinocytes or rapidly adhering cells, at 2 different seeding densities. As shown in Table 5.1, the size of the integrin-bright patches was the same whether unselected or rapidly adhering cells were plated and was not affected by a 10 -fold difference in plating density.

I investigated the relationship between patch size and plating density in more detail using rapidly adherent cells. Keratinocytes were seeded onto $100 \mu \mathrm{g} / \mathrm{ml}$ type IV collagen at densities ranging from 200 to $10^{5}$ per $8 \mathrm{~cm}^{2}$ dish and non-adherent cells were removed after $20 \mathrm{~min}$. The density of attached cells ranged from $6 \times 10^{\circ}-3.2 \times$ $10^{3}$ per $\mathrm{cm}^{2}$. As shown in Table 5.2, there was no significant difference in patch size or the percentage of integrin-bright cells over a 500 fold range of seeding densities. Patterning must therefore be regulated by keratinocyte-keratinocyte interactions (Figure 5.2).

As few as 50 cells were able to reconstitute a patterned array of integrin-bright and integrin-dull basal keratinocytes over an $8 \mathrm{~cm}^{2}$ dish (Table 5.2). This implied that multiple integrin bright and dull patches can be formed by the clonal progeny of a single stem cell. To confirm that this was the case I cultured rapidly adherent keratinocytes on slides for 1,3, 5 and 7 days and then stained the colonies for $\alpha_{2}$ and $\alpha_{3}$ integrin subunits. By 5 days colonies containing at least 2 discrete integrin-bright patches had formed (Figure 5.3).

\section{Regulation of stem cell fate}

The decision of a stem cell to differentiate might be stochastic, environmentally regulated, or predetermined, for example by a cell division counting clock (see Chapter 1, (Temple and Raff 1986; Barres and Raff 1994)). If keratinocyte differentiation is clock driven, it should follow that differentiated keratinocytes derived from single stem cells would have executed more rounds of cell division than undifferentiated keratinocytes derived from the same cell. The lineage of keratinocytes can be followed by labelling them with the fluorescent dye PKH 26, which covalently binds lipids in the cell membrane and is diluted at each successive cell division. The dye is very stable in living cells; in the absence of cell division it has a half life of 120 days in lymphocytes in vivo (Horan 1990). Cells which withdraw from the cycle retain higher levels of the dye than cells which continue to proliferate, as dye is partitioned between the daughter cells at each cell division (Ashley et al. 1993; Boyd 1993). This method offers an alternative to time lapse video microscopy of single colonies, which has considerable limitations (Dover and Potten 1988). 
The viability of labelled cells was over $95 \%$, as assessed by propidium iodide exclusion. Labelled cells were plated on type IV collagen $(100 \mu \mathrm{g} / \mathrm{ml})$ on multiwell slides or $60 \mathrm{~mm}$ dishes for 20 minutes, non adherent cells washed off, feeder cells added and the cells cultured for 1, 3,5 and 7 days. By 7 days the cultures had reached confluence. Cells on slides were then stained with anti-integrin antibodies conjugated to fluorescein and examined on the confocal microscope. Cells in dishes were harvested and analysed by FACS, the level of fluorescence in the cultured keratinocytes was compared with that of labelled cells from the start of the experiment which had been fixed in $1 \%$ paraformaldehyde and kept in the dark at $4^{\circ} \mathrm{C}$ until analysed.

The results of the FACS analysis are shown in Figure 5.4. Basal cell and terminally differentiated keratinocytes were identified by their light scatter (see Figure 3.1 and Chapter 3). The level of dye fluorescence was markedly higher in the differentiated cells, suggesting they had undergone fewer rounds of cell division than the basal cells.

The appearance of colonies formed by labelled cells is illustrated in Figure 5.5. In some transit cell derived colonies dye appeared evenly distributed between cells (Figure 5.5A). However in stem cell derived colonies of over 32 cells there was marked heterogeneity in the distribution of dye. Figures 5.5B shows a colony with a large cell that is PKH 26-bright. The diameter of the cell is over $75 \mu \mathrm{m}$, suggesting it is involucrin positive, as almost all cultured keratinocytes with a diameter over $25 \mu \mathrm{m}$ have been found to express involucrin (Watt and Green 1981). Similarly, in the colony shown Figure 5.5C there is a dye-bright cell that is suprabasal, and has therefore differentiated. When the integrin-bright basal cells are examined some appear relatively dye bright, whereas others have only a very low level of PKH 26 fluorescence (Figures 5.5B, C).

These results are preliminary. The involucrin expression of cells in dye labelled colonies will be analysed to confirm that the large dye bright cells are indeed terminally differentiated. The percentage of involucrin-positive cells in unlabelled controls will also be examined, to ensure that the dye is not affecting the differentiation of the cells. Nevertheless, these observations suggest that, in clonal growth in vitro, keratinocytes do not have to complete a predetermined number of rounds of cell division before terminally differentiating. 


\section{Discussion}

Keratinocytes are able to interact to produce a spatially patterned array of stem cells and more differentiated basal cells in the absence of an underlying dermis. The interaction is regulated so that the same pattern is produced over a wide range of seeding density and is not affected by whether cells are grown from stem cell enriched or unselected cell populations (Figure 5.2). The clonal progeny of a single stem cell can establish a discrete patches of integrin bright and dull cells. These observations show that the behaviour of stem cells and their progeny is regulated by cell-cell interactions.

Interactions between epithelial cells are known to regulate cell fate patterning in Drosophila (Peifer and Bejsovec 1992; Muskavitch 1995). In the epidermis of the Drosophila embryo cells that become committed to the neural lineage signal to their neighbours to differentiate into epidermal cells. This interaction, termed lateral inhibition, is mediated via the cell surface receptors Notch, Delta and Serrate. Two human Notch homologues have been identified, but their expression in cultured keratinocytes is not known. Homologues of Delta and Serrate have not yet been found in human epidermis. Nevertheless, lateral inhibition, possibly mediated by cell-cell contact, could account for generation of cell fate patterning in cultured epidermis.

The results of pilot studies with dye dilution show that PKH 26 will be very useful as a lineage marker in keratinocytes. The preliminary data show that cells that appear to be terminally differentiated have undergone fewer rounds of cell division than undifferentiated cells. These observations are consistent with the results of time lapse video microscopy and the analysis of cell cycle times in cultured keratinocytes (Albers et al. 1986; Albers et al. 1987; Dover and Potten 1988). The implications of the apparent dissociation between the number of rounds of cell division executed by a cell and the fate of its daughters are discussed in Chapter 7.

The further study of keratinocyte cell fate decisions would be facilitated by the availability of more specific markers for stem and transit cells. An approach to find such markers is set out in the next chapter. 
Table 5.1: Integrin-bright patches formed in sheets of cultured keratinocytes: comparison of unselected and rapidly adhering cells

\begin{tabular}{|c|c|c|c|c|}
\hline Cells & $\begin{array}{c}\text { Plating } \\
\text { density (per } \\
8 \mathrm{~cm}^{2} \text { dish) }\end{array}$ & $\begin{array}{c}\text { Days to } \\
\text { confluence }\end{array}$ & Patch size,4 & $\begin{array}{c}\text { \% bright } \\
\text { cells }\end{array}$ \\
\hline $\begin{array}{c}\text { unselected } \\
\text { rapidly } \\
\text { adhering1 }\end{array}$ & $2 \times 10^{5}$ & 4 & $11.0 \pm 1.1$ & $44.6 \pm 1.3$ \\
\hline $\begin{array}{c}\text { unselected } \\
\text { rapidly } \\
\text { adhering }\end{array}$ & $2 \times 10^{4}$ & 8 & $11.9 \pm 1.2$ & $46.5 \pm 1.3$ \\
\hline
\end{tabular}

Notes

1 Selected by attachment to $100 \mu \mathrm{g} / \mathrm{ml}$ type IV collagen for $20 \mathrm{~min}$ (see Jones and Watt, 1993)

2 Cultures were harvested 3 days post confluence

3 Vertical sections through the cultures were labelled with antibodies to the $\alpha_{2}$ integrin subunit

4 Values are mean \pm SEM 
Table 5.2: Integrin-bright patches formed in sheets of cultured keratinocytes: comparison of rapidly adhering cells plated at different densities

\begin{tabular}{|c|c|c|c|c|c|}
\hline $\begin{array}{c}\text { Plating } \\
\text { density1 (per } \\
8 \mathrm{~cm}^{2} \text { dish) }\end{array}$ & $\begin{array}{c}\text { Days to } \\
\text { confluence }^{2}\end{array}$ & $\begin{array}{c}\text { Patch } \\
\text { size }^{3}\left(\alpha_{2}\right)\end{array}$ & $\begin{array}{c}\% \text { bright } \\
\text { cells }\left(\alpha_{2}\right)^{3}\end{array}$ & $\begin{array}{c}\text { Patch } \\
\text { size }^{3}\left(\alpha_{3}\right)\end{array}$ & $\begin{array}{c}\text { \% bright } \\
\text { cells }\left(\alpha_{3}\right)^{3}\end{array}$ \\
\hline $10^{5}$ & 7 & $10.1 \pm 2.4$ & $45 \pm 1.4$ & $11.5 \pm 1.8$ & $53 \pm 1.5$ \\
\hline $10^{3}$ & 16 & $10.8 \pm 1.3$ & $52 \pm 1.4$ & $9.6 \pm 1.6$ & $49 \pm 1.6$ \\
\hline 200 & 19 & $9.6 \pm 1.5$ & $51 \pm 1.3$ & $12.0 \pm 2.0$ & $49 \pm 1.1$ \\
\hline
\end{tabular}

Notes

1 After attachment to $100 \mu \mathrm{g} / \mathrm{ml}$ type IV collagen for $20 \mathrm{~min}$ non-adherent cells were removed (see Jones and Watt, 1993)

2 Cultures were harvested 2-3 days post confluence

3 Values shown are mean \pm SEM. There was no statistically significant difference between patch size and \% bright cells at any plating density and for either integrin subunit (Mann Whitney U test). 
FIGURE 5.1: Integrin expression in cultured epidermal sheets

Keratinocytes were grown on tissue culture plastic to form a confluent stratified sheet, removed from the culture dish by incubation with Dispase and either sectioned prior to staining (A, B) or stained as a whole-mount (C).

A) low power view B) high power view of a section of a folded confluent sheet (in B sheet is folded so that basal layer is uppermost in top section), stained for $\alpha_{3}$ integrin subunit. Sheet was generated by cultured keratinocytes that adhered to $100 \mu \mathrm{g} / \mathrm{ml}$ type IV collagen within $20 \mathrm{~min}\left(2 \times 10^{4}\right.$ cells plated per $35 \mathrm{~mm}$ dish $)$.

C) Epidermal sheet stained for $\alpha_{3}$ integrin subunit. $10^{5}$ cells were plated onto 100 $\mu \mathrm{g} / \mathrm{ml}$ type IV collagen and allowed to attach for $24 \mathrm{hr}$.

Specimens were examined with a confocal microscope; colour indicates fluorescence intensity, increasing from dark blue through to pink as shown. Scale bars $=50 \mu \mathrm{m}$. 


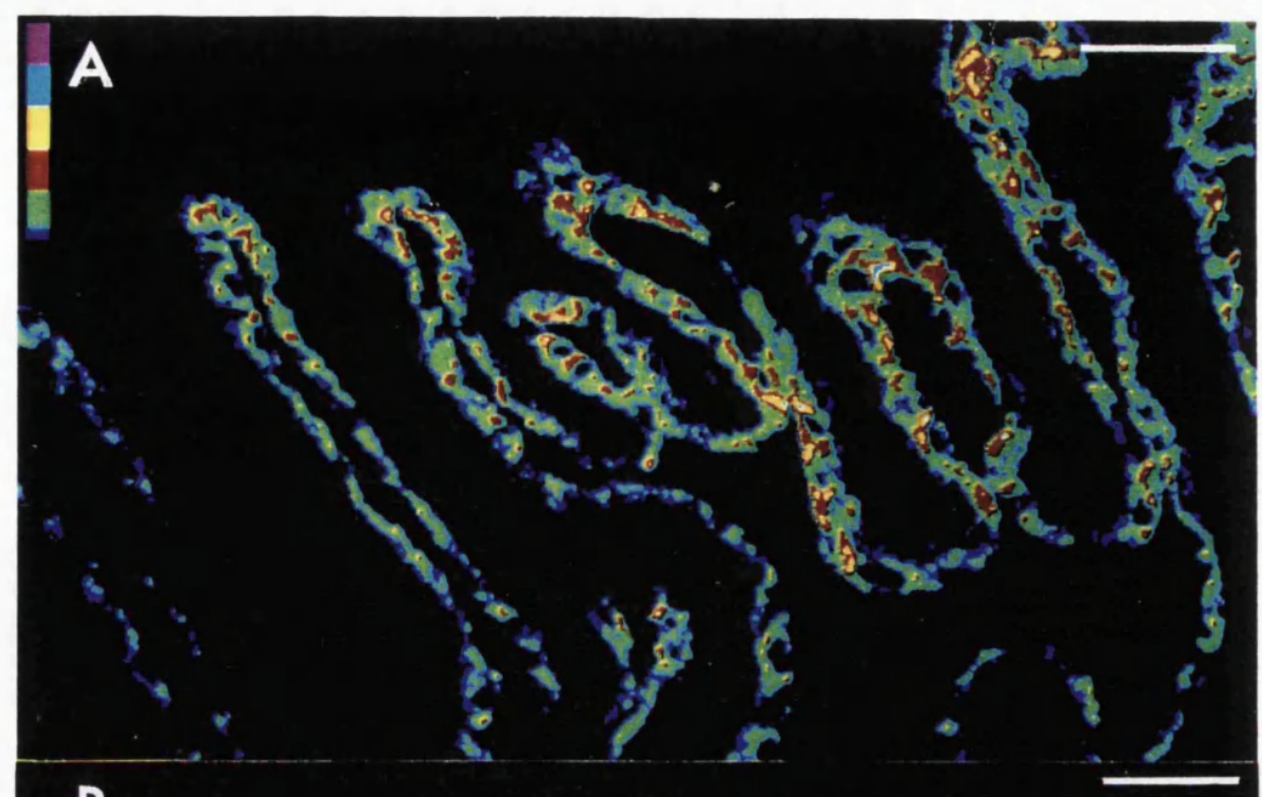

B

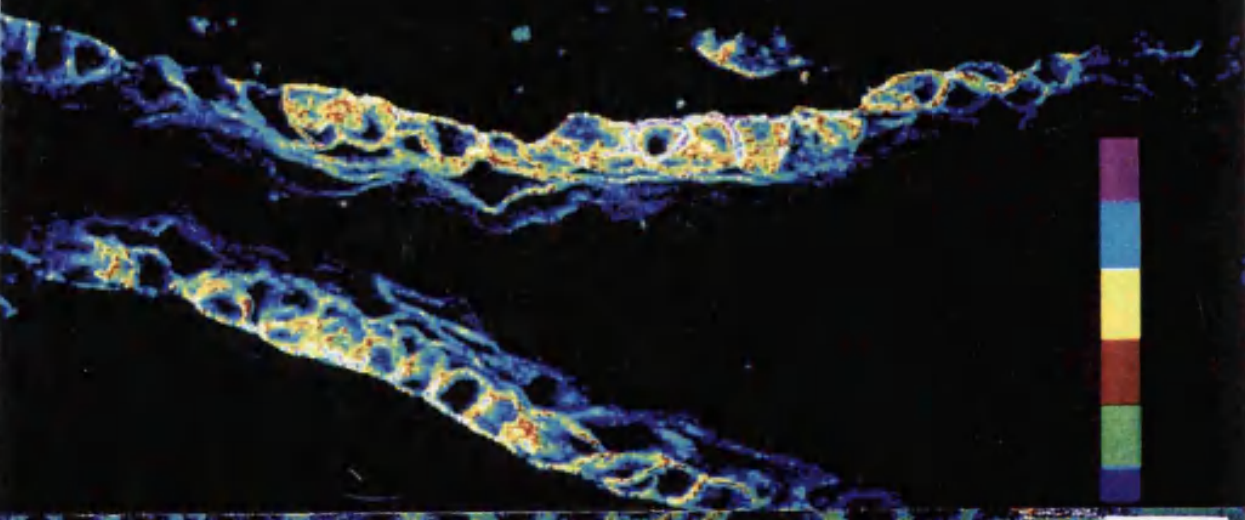

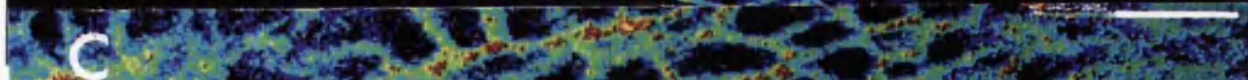
28
3 


\section{FIGURE 5.2: Pattern formation in cultured keratinocytes}

The same pattern of integrin bright patches (red) and integrin dull cells (blue) is seen over a 500 fold range of seeding density of rapidly adherent keratinocytes This difference is equivalent to 8 rounds of cell division for each stem cell. Randomly arrayed stem cells produce the same pattern at either seeding density. At the lower density each stem cell produces an array of stem and non stem cells covering an average of $17 \mathrm{~mm}^{2}$. 

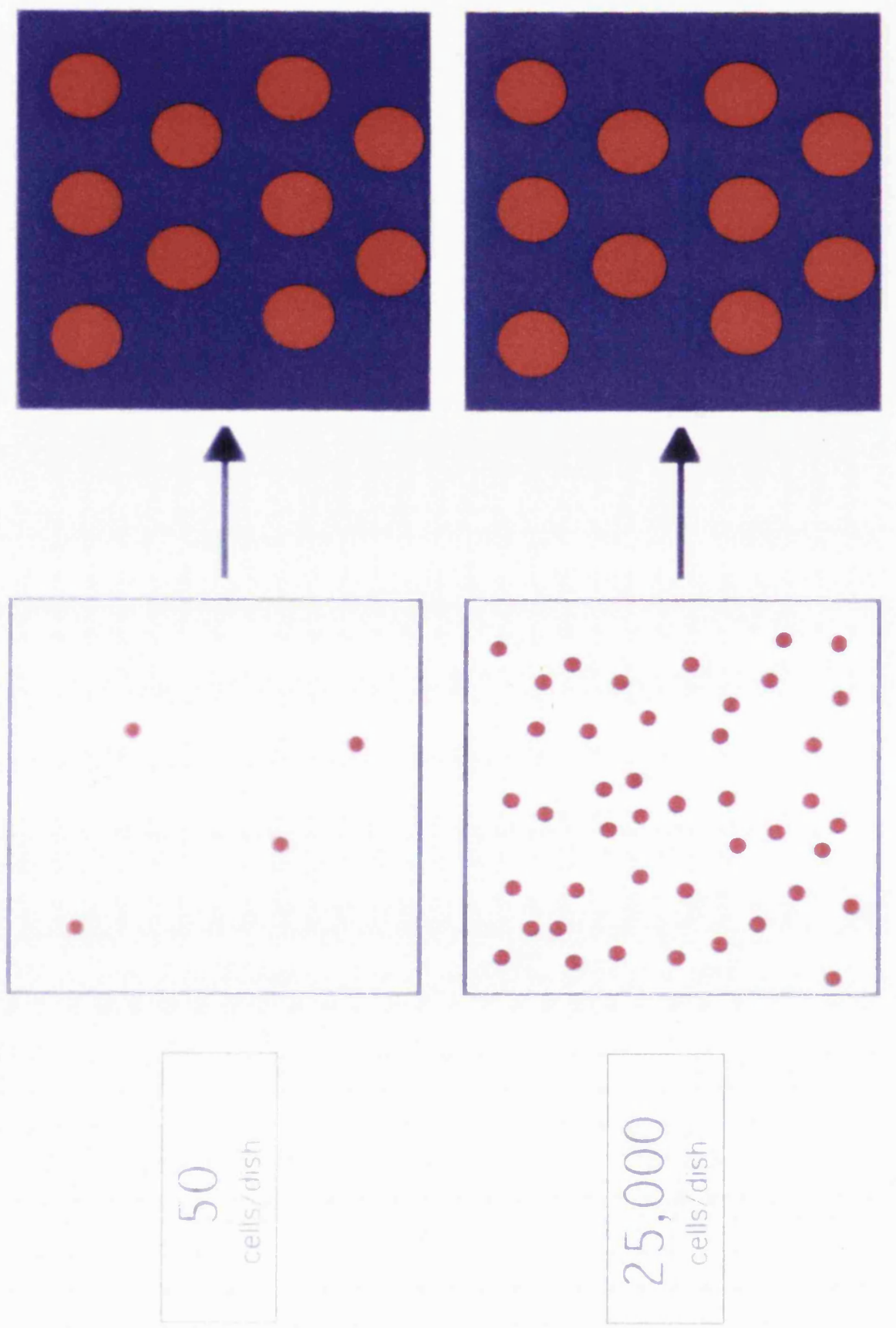
FIGURE 5.3: Colony containing multiple integrin bright and dull patches

Cultured keratinocytes were allowed to attach to slides coated with $100 \mu \mathrm{g} / \mathrm{ml}$ type IV collagen for 20 minutes. Non adherent cells were removed and feeders were added. The cells were cultured for 5 days and then stained with anti integrin antibodies conjugated to fluorescein. The colony shown, which contains over 150 cells, has been stained with the anti $\alpha_{3}$ integrin subunit antibody, VM2-FITC. The colour corresponds to the intensity of staining, increasing from blue through to pink on a linear banded scale as shown. $\mathrm{S}$ indicates the position of suprabasal cells, which are integrin-negative.

Scale bar: $50 \mu \mathrm{m}$. 


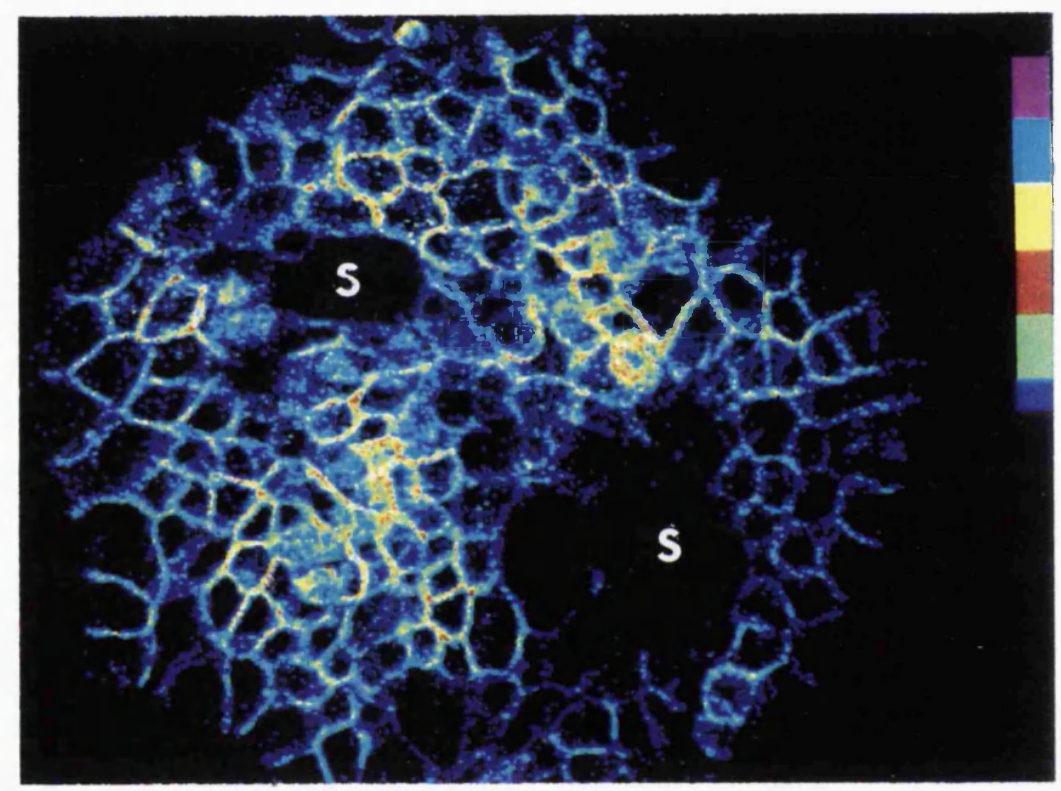




\section{FIGURE 5.4: Analysis of PKH 26 dilution by FACS}

Keratinocytes were labelled with PKH 26. An aliquot of labelled cells fixed in $1 \%$ PFA and stored at $4^{\circ} \mathrm{C}$ in the dark. $5 \times 10^{4} \mathrm{PKH} 26$ labelled keratinocytes were allowed to attach to $60 \mathrm{~mm}$ diameter dishes coated with $100 \mu \mathrm{g} / \mathrm{ml}$ type IV collagen for 20 minutes. The non adherent cells were then removed, and the adherent cells cultured. After 5 and 7 days of culture the cells were harvested and analysed on a FACStar plus flow cytometer, with one laser tuned to $488 \mathrm{~nm}$ and a second laser to $515 \mathrm{~nm}$, the secondary absorption peak of PKH26.

A and B) Fluorescence histograms showing PKH26 fluorescence in arbitrary units on a $\log$ scale on the $x$ axis and cell number on a linear scale on the $y$ axis. Basal and suprabasal cells were identified by light scatter (Figure 3.1). The solid red line shows the fluorescence of labelled basal cells at the start of experiment, the pink line the fluorescence of suprabasal cells and the blue line the fluorescence of basal cells, at 5 days (A) and at 7 days (B).

Unlabelled cells were used as a negative control: the upper limit of control fluorescence is shown by the marker on the $\mathrm{x}$ axis. The proportion of dye-positive suprabasal cells was $76 \%$ at 5 days and $48 \%$ at 7 days. In contrast the proportion of dye-positive basal cells was $10 \%$ at 5 days and only $1 \%$ at 7 days. 
$\infty$

D
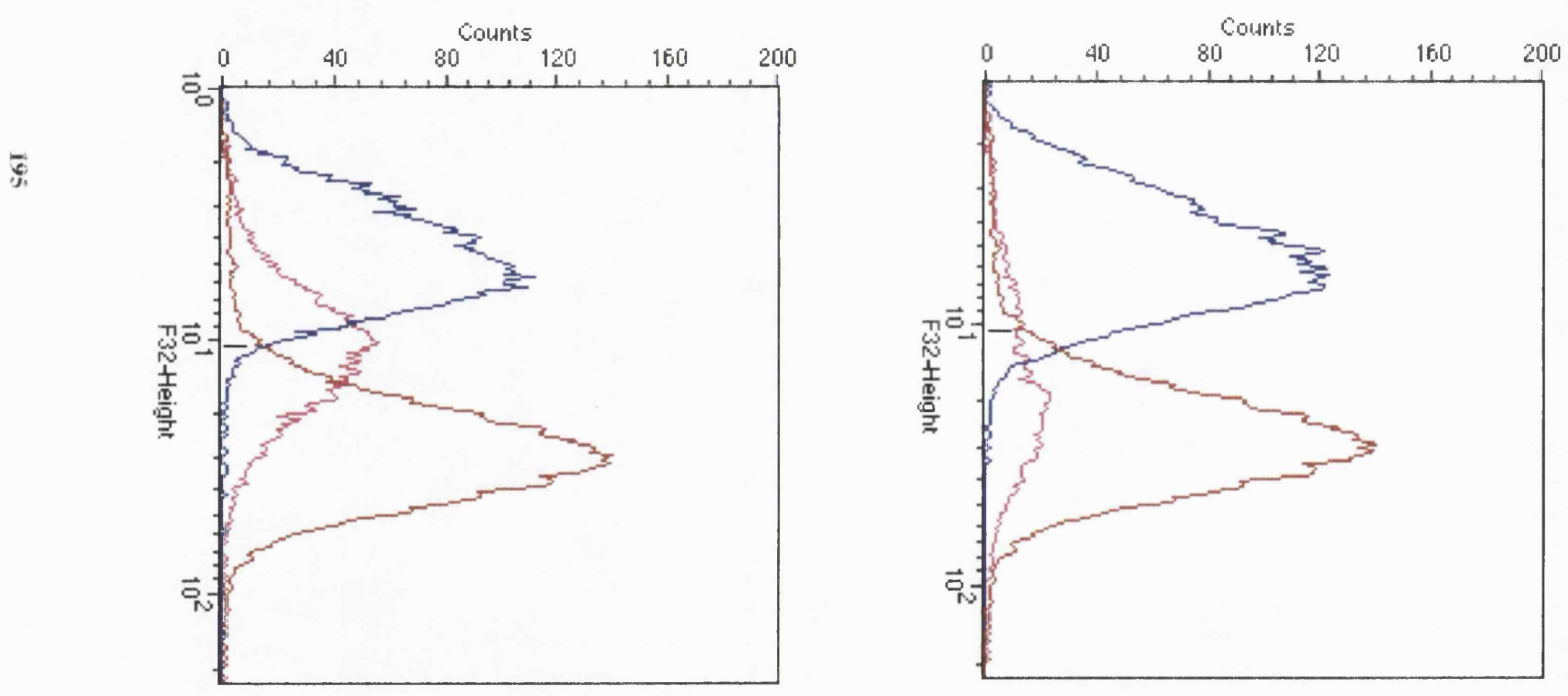


\section{FIGURE 5.5: Appearance of PKH26 labelled colonies}

Cultured keratinocytes labelled with the red dye PKH26 were allowed to attach to slides coated with $100 \mu \mathrm{g} / \mathrm{ml}$ type IV collagen for 20 minutes. Non adherent cells were removed and feeders were added. The cells were cultured for 3 days (A) or 5 days, (B and $C$ ), stained with a directly conjugated antibody to the $\alpha_{3}$ integrin subunit, VM2FITC, fixed in $1 \%$ PFA, and viewed on the confocal microscope.
A) 4 cell colony. Dye has redistributed from the cell membrane to the interior of each, and appears evenly distributed between cells.
B) 42 cell colony. A single large dye bright cell with a diameter of over $75 \mu \mathrm{m}$ is seen.
C) A colony of over 115 cells. A single dye bright suprabasal cell is seen.

Scale bars: $A=25 \mu \mathrm{m}, \mathrm{B}, \mathrm{C}=50 \mu \mathrm{m}$. 


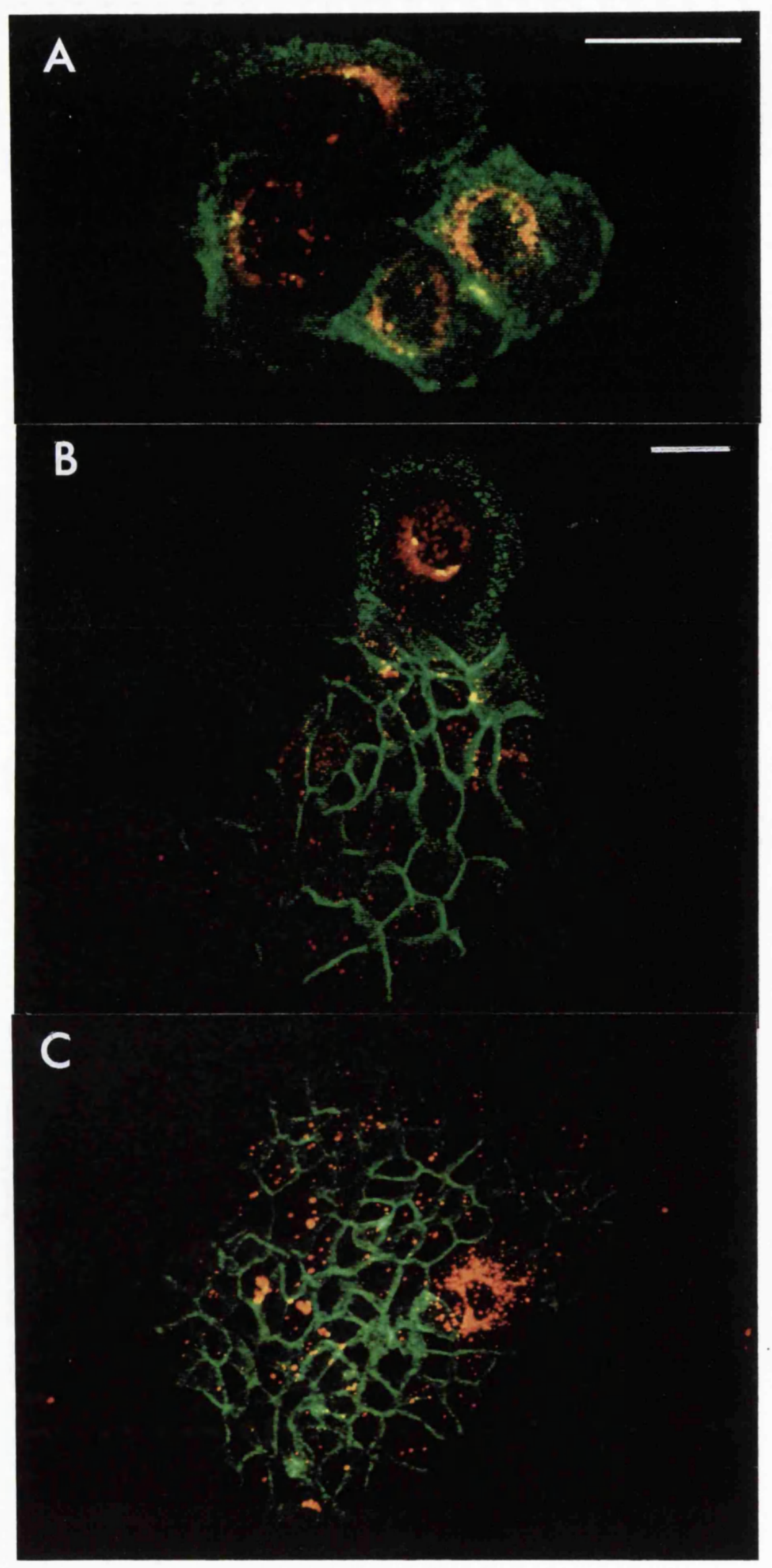




\section{CHAPTER 6 \\ STRATEGY FOR IDENTIFICATION \\ OF NOVEL STEM CELL MARKERS \\ AND REGULATORY GENES}

\section{INTRODUCTION}

Stem cells can be distinguished from transit cells in vitro and in vivo on the basis of differences in surface integrin expression and adhesiveness (see Chapters 3 and 4). Although 2 fold quantitative differences in the surface levels of $\beta_{1}$ integrins enable stem cells to be localised in vitro and in vivo, only about 1 in 4 of the cells in an integrin-bright patch in vivo is clonogenic in vitro. Further studies of pattern formation and stem cell behaviour will require more specific molecular markers of stem cells that define the stem cell population more precisely. For this reason I set out to isolate genes that are differentially expressed between stem and transit cells. As there are several examples of differential in gene expression determining the fate of cells this approach may yield genes that regulate differentiative decisions as well as novel stem cell markers.

Several approaches have been used to isolate differentially expressed genes (Sambrook et al. 1989; Kriegler 1990), each with its own limitations. The differential display polymerase chain reaction (Liang and Pardee 1992; Liang et al. 1993; Utans et al. 1994) is one approach but I was concerned that differences in gene expression may be masked in the amplification process. Cultured keratinocytes that attach to type IV collagen within 20 minutes ( $0-20$ cells) only differ about 10-12 fold in CFE from those that adhere in over 1 hour (60+ cells). The alternative is to use subtractive hybridisation, in which differentially expressed genes are detected by making a probe that only contains sequences unique to the cell population of interest. To do this a small quantity of single stranded cDNA from the cell population of interest (the target) is hybridised with an excess of RNA from another cell population (the driver). Driver-target hybrids are removed leaving cDNAs unique to the target.

Efficient subtractive hybridisation requires conditions where hybridisation between the genes expressed in both target and driver is as near $100 \%$ as possible. Under conditions where the driver is in over 10 fold excess over the target, if the 
concentration of unhybridised target DNA is D and the starting concentration of target is $D_{0}$, the proportion of unhybridised target, $D / D_{0}$ is given by the expression

$$
D / D_{0}=e^{-\left(k R_{0} t\right)}
$$

in which $\mathrm{k}$ is a constant, $\mathrm{R}_{\mathbf{0}}$ is the initial concentration of RNA driver and the time of hybridisation. To achieve $99.9 \%$ subtraction typically requires an $R_{0 .} t$ product of over 1000 moles.s..$^{-1}$ (Sargent 1987). Once driver-target hybrids have formed it is essential they be efficiently removed from the reaction mixture.

There are many published methods of subtractive hybridisation. Protocols using hydroxylapatite chromatography and biotinylated driver RNA require large quantities of RNA (Kriegler 1990). Another approach is to conjugate the driver to magnetic beads (Rodriguez and Chardre, 1992). Although this enables efficient removal of driver-target hybrids, hybridisation cannot be carried out to very high $R_{\text {o.t values. }}$

I opted to use chemical cross linking subtraction hybridisation (CCLS, see Figure 6.1), which has the advantages of efficient hybridisation and driver-target hybrid removal and does not require prohibitive quantities of RNA (Hampson, et al. 1992). CCLS was used to isolate the WAF1 gene from a human brain tumour line (ElDeiry et al. 1993). Hybridisation is carried out in a single tube to $R_{0} . t>2500$ mole.seconds/l (Young and Anderson 1985; Kriegler 1990). This corresponds a hybridisation time of at least 24 hours using $20 \mu \mathrm{g}$ mRNA in $10 \mu 10.5 \mathrm{M} \mathrm{NaCl}$. The cDNA/RNA hybrids are then covalently cross-linked using 2,5 diaziridinyl-1,4benzoquinone and the hybridisation repeated with fresh driver RNA to a similar $\mathbf{R}_{\mathbf{0}}$.t. The cross-linking is highly efficient and irreversible. The radiolabelled probe is synthesised with Sequenase, which only uses single stranded cDNA as a template.

The method requires at least $40 \mu \mathrm{g}$ poly $\mathrm{A}^{+} \mathrm{RNA}$ as driver. As $60+$ keratinocytes only comprise $5-10 \%$ of the cells in a preconfluent culture, it was necessary to construct a cDNA library from the $60+$ cells to produce the driver RNA by in vitro transcription. This library will also be useful for detection of markers of transit cells. 
The probe was used to screen a cDNA library prepared from 0-20 cells to maximise the probability of detecting rare transcripts. Having the 0-20 cell library also makes it possible to use $0-20$ cell RNA as a driver and 60+ cell cDNA as a target, to probe for early markers of differentiation.

Preconfluent cultures were used as a source of RNA for library and probe construction as up to $90 \%$ of the keratinocytes in such cultures that adhere to collagen type IV within 20 minutes are stem cells. Furthermore stem and transit cells are actively proliferating in preconfluent cultures. This is an advantage over confluent cultures where stem cells are less proliferative than transit cells. A subtraction using confluent cells might detect genes upregulated in quiescent cells (Del Sal et al. 1992), as well as markers of proliferative potential.

\section{RESULTS}

Library construction and the making of the subtracted probe are detailed in Chapter 2. The subtracted probe was used to screen 100000 colonies of the $x 1$ amplified 0 20 cell cDNA library (equivalent to approximately 50,000 independent transformants (Kriegler 1990)). 50 positive colonies were detected. Clones were picked and a secondary screen carried out using the same batch of subtracted probe (see Figures 6.2 and 6.3). The positive clones await further characterisation.

\section{Discussion}

Once clones are isolated I plan to cut out inserts to use them to probe Northern blots prepared from 0-20,60+ and non adherent (ie committed and suprabasal) cells. Differentially expressed genes will then be sequenced. In situ hybridisation may provide information as to whether the genes are expressed by stem cells in vivo (Jones et al. 1995), provided the copy number of a gene is sufficient to allow detection. Gene function could be assayed by stably expressing the genes in keratinocytes using retroviral vectors. 
FIGURE 6.1: Production of a subtracted probe

Outline of method for production of subtracted probe (for details see Chapter 2).

Target was single stranded cDNA reverse transcribed from 0-20 cell mRNA (hatched red bar) and extracted from cells adhering to type IV collagen within 20 minutes. cDNA species unique to stem cells are shown as red solid bars. cDNA species common to stem and non stem cells are shown as solid blue bars:

Driver RNA (hatched blue bars) was transcribed from a linearised $60+$ cell library in pSport, using SP6 RNA polymerase. RNA species unique to $60+$ cells are shown as green hatched bars.

Target and driver were allowed to hybridise in solution for at least 24 hours, and then RNA-DNA hybrids are covalently cross linked using DZQ (pink bars). The process was then repeated with fresh driver RNA.

After the second round of cross linking, the radioactive probe was synthesised using random priming with the enzyme Sequenase, which only labels single stranded DNA.

The probe was then used to screen a 0-20 cell library (Figure 6.2). 
TARGET

Synthesise first strand CDNA

0-20 cell mRNA, ,...AAAAAA

CDNA unique to $0-20$ cells

CDNA in 0.20

and $60+$ cells
DRIVER

Transcribe RNA from non stem library

Linearised non stem library

$\begin{array}{lll}\text { SP6 TTITT Sal } 1 & \end{array}$

'ÓÁÁÁM"

RNA unique to "and $60+$ cells

$60+$ cells

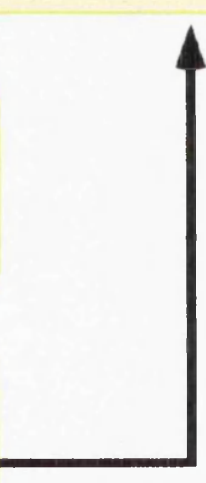

REPEAT WITH FRESH DRIVER

3010101010

1001001

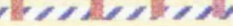

eversible cross linking

H

HYBRIDISE in SOLUTION
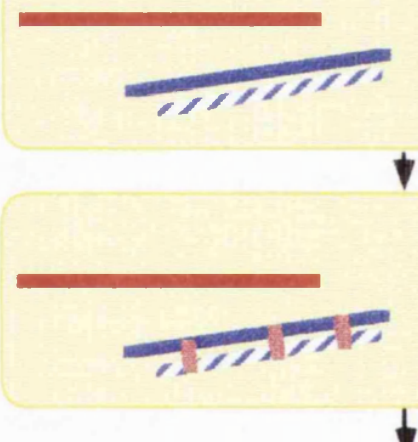

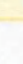

RADIOLABEL with SEQUENASE

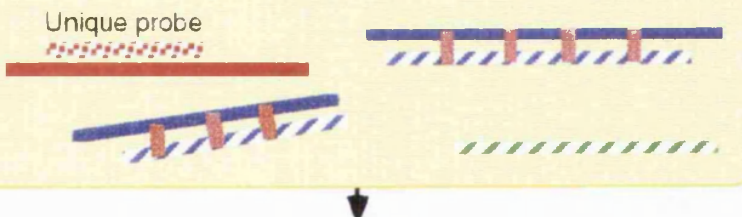

SCREEN LIBRARY 
FIGURE 6.2: Primary Screening of 0-20 cell library with subtracted probe

$10^{5}$ colonies of a $x 1$ amplified 0-20 cell cDNA library (approximately 50,000

independent transformants) were grown on a Hybond (Amersham) nylon filter.

Duplicate replica filters were then made from the master filter. DNA was denatured and the filters were baked. After hybridisation with the subtracted probe filters were washed and autoradiographed. Positive clones were identified from signals that matched on both autoradiographs. After picking, bacteria were cultured and streaked on agar plates, and screened as in Figure 6.3. 


\section{Grow colonies}

on filter

Make duplicate replica filters

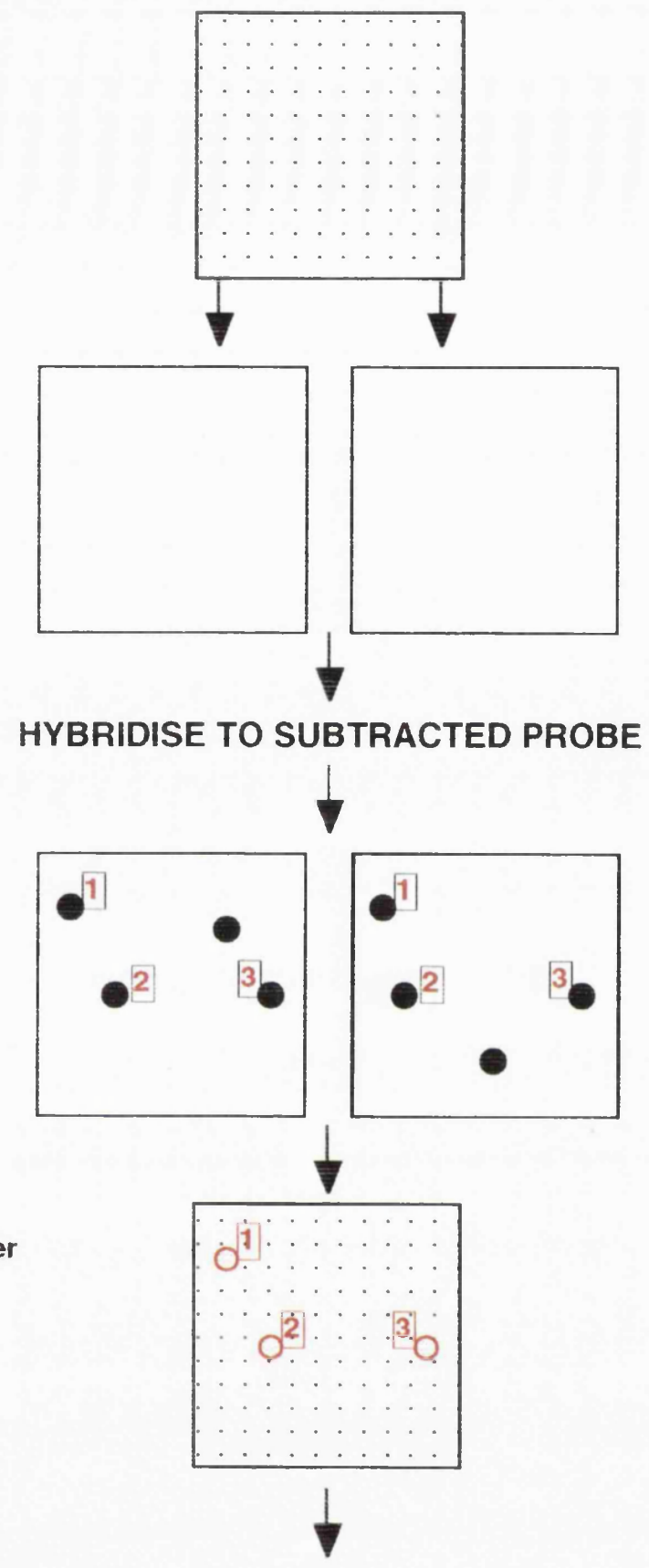

Culture Positive isolates

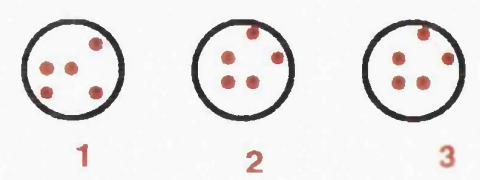


FIGURE 6.3: Secondary screening of positive isolates from primary screen

10 discrete colonies were picked from each primary screen culture plate (only 5 are shown for simplicity, Figure 6.2). These were spotted onto a gridded filter and grown for 2 hours. The same isolates were also inoculated into a 96 well plate, numbered in the same fashion as the filter. DNA on the filter was then denatured, the filter baked and hybridised with subtracted probe. Positive clones were identified by autoradiography and then grown in culture from the corresponding stock in the 96 well plate. Miniprep DNA of each positive isolate was then digested with restriction enzymes (Pst 1 and Hinf1). The fragment sizes were checked by agarose gel electrophoresis to ensure that the positive colonies from each primary screen dish were identical and to ascertain the insert size. 
Pick single colonies from primary screen plates, 10 from each filter

\section{Grow on gridded filter} Culture in 96 well plate

Make duplicate filter hybidise to subtracted probe Develop autorad

Identify positives and pick 1rom 96 well plate

Culture each postive clone Miniprep DNA

Restriction digest to ensure identity of positives
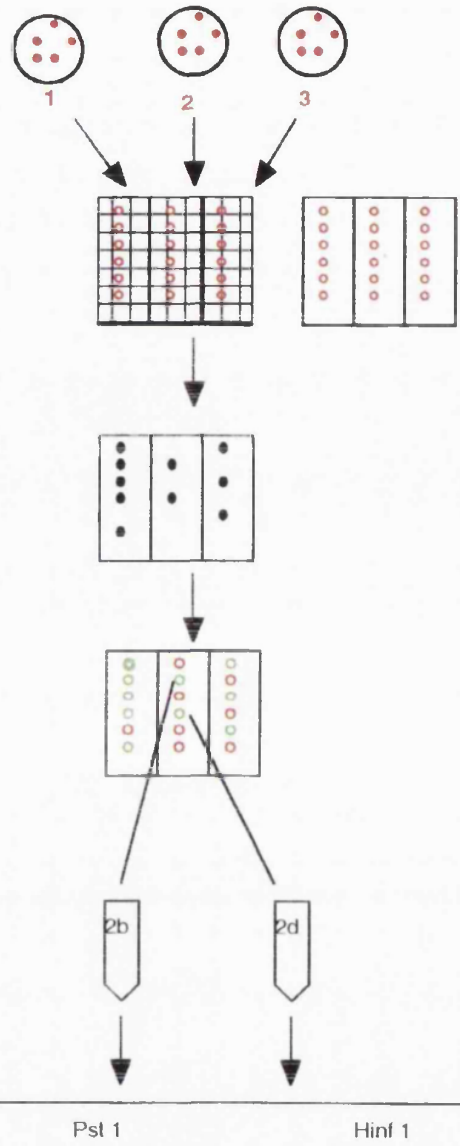

plasmid $2 b \quad 2 d$ plasmid $2 b \quad 2 d$

- $- \pm-\square-$ 


\section{CHAPTER 7 \\ GENERAL DISCUSSION}

I have shown that basal keratinocytes with the characteristics of stem cells epidermal stem cells can be isolated in vitro and in vivo because they express high levels of functional $\beta_{1}$ integrin receptors for extracellular matrix (ECM) proteins found in the epidermal basement membrane and adhere more rapidly than other basal cells when plated onto ECM proteins (Chapters 3 and 4; Jones and Watt 1993; Jones et al. 1995). The stem cells are clonogenic, exhibit self renewal in vitro and are able to reconstitute an epidermis in vivo when grafted onto nude mice. They give rise to a population of transit cells which adhere more slowly to ECM and have a lower level of surface $\beta_{1}$ integrins (Jones and Watt 1993; Jones et al. 1995). In accordance with the predictions of Lajtha and Potten they are less likely to be proliferating than transit cells in the steady state in vivo (Lajtha 1979; Potten 1981; Potten and Morris 1988). Stem cells have a patterned distribution in vivo. The patterning can be reconstituted in vitro suggesting that interaction between keratinocytes regulates cell fate (Chapter 5, Jones et al. 1995). Being able to isolate stem cells I was able to perform subtractive hybridisation to isolate stem cell specific cDNAs (Chapter 6). A model of the subpopulations of cells in the basal layer of the in the epidermis is shown in Figure 7.1.

\section{Stem cell fate}

The mechanism of stem cell fate determination will be studied further in subcloning experiments. If stem cell division is stochastic the subcloning of stem cell colonies should generate stem cells, transit cells and post mitotic cells in varying proportions. The daughters of a single stem cell would differentiate or self renew at random, and form a range of different colony types. The number of stem cell colonies would be determined solely by the probability of stem cell self renewal. If stem cells differentiated in response to an internal clock the fate of the daughters of a stem cultured separately would be identical (Temple and Raff 1986).

Whether stem cell fate is stochastic or predetermined the existence of patterning in vitro suggests that stem cell fate is modulated by the microenvironment of the stem cell. Contact mediated lateral inhibition, similar to the Notch/Delta system in Drosophila, may operate in keratinocytes. It may be possible to demonstrate this by placing PKH26 marked stem cells in direct contact with unlabelled populations of purified stem or transit cells in vitro. Progeny of the labelled cells could be recovered by FACS sorting and placed in culture, to see if cell contact mediated signals had changed their fate. 
Growth factors modulate the fate of both cells whose cell fate decisions are stochastic and those in which differentiation is clock driven (Fairburn and Cowling 1993; Barres et al. 1994). There is indirect evidence that the presence of factors such as TGF $\alpha$ or EGF can increase the promote the self renewal of keratinocyte stem cells (Green 1978; Barrandon and Green 1987a). It will now be possible to examine the effect of growth factors on keratinocyte stem cells directly.

\section{Integrins and stem cells}

Integrins are likely to be more than just stem cell markers. Recent work has shown that $\beta_{1}$ integrins can activate the ras/mitogen activated kinase signalling pathway, via a protein kinase called focal adhesion kinase (FAK), which is localised in focal adhesions (see Figure 1.6). (Schaller et al. 1992). In fibroblasts plated on fibronectin FAK is phosphorylated and then bound by the GRB2 adaptor protein and the c-Src protein tyrosine kinase (Schlaepfer et al. 1994). The GRB2 protein is then activates the Ras/mitogen associated protein kinase signal transduction cascade. This signalling pathway is known to mediate cell fate decisions and proliferation in a wide range of cells in vertebrates and invertebrates (Hafen et al. 1993).

FAK is present in focal contacts in cultured keratinocytes. It is phosphorylated in keratinocytes adhering to fibronectin via $\alpha_{5} \beta_{1}$ integrin, but not in keratinocytes adhering to polylysine, where attachment is integrin independent (Gates et al. 1994). In vivo, FAK is localised to the epidermal-dermal junction at the edge of healing wounds (Gates et al. 1994), where the cells are migrating and highly proliferative (Grinnell 1992). This evidence suggests that integrin receptors on stem cells may play a role in transducing signals that regulate stem cell proliferation and or cell fate. Integrins also transduce signals that block differentiation independent of focal contact formation (Adams and Watt 1989; Hotchin et al. 1993). Retroviral transfection could be used to increase or decrease the level of $\beta_{1}$ integrins in stem cells, to see if the altering the level of $\beta_{1}$ integrin expression in stem cells changes their behaviour.

Integrins may also be implicated in stem cell patterning in development. Patches of bright and dull integrin expression are found in developing epidermis as well as in adult skin. In humans patchy expression of the $\alpha_{2}$ subunit is seen in basal keratinocytes coinciding with the onset of stratification at 9 weeks estimated gestational age (EGA) (Hertle et al. 1991). At 15 weeks EGA intensely bright $\alpha_{2}$ patches are seen at the sites of developing sweat ducts. $\alpha_{3}, \alpha_{6}$ and $\beta_{1}$ integrin subunit fluorescence appeared uniform in all basal cells from 9 weeks EGA. The indirect immunofluorescence techniques used in this study may not have detected the 2 fold 
variation in integrin expression seen in the basal keratinocytes of adults (Hertle et al. 1991). Examination of sections developing epidermis stained with directly conjugated antibodies by confocal microscopy may reveal integrin-bright and integrin-dull patches for other integrin subunits as well as $\alpha_{2}$. In interpreting such results it would be important to confirm that high $\beta_{1}$ integrin expression is a marker of stem cells in foetal keratinocytes as well as in adult cells.

There is also evidence that integrins may interact with proteins that are homologous to genes involved in cell fate determination in Drosophila. Integrins and cadherins interact via $\beta$ catenin in keratinocytes in vitro (Figure 7.2) (Hodivala and Watt 1994, K Hodivala, V Braga, F Watt, unpublished observations). $\beta$ catenin a the mammalian homologue of Drosophila Armadillo (Peifer and Wieschaus 1990; Peifer et al. 1992), one of the genes in the Wingless signalling pathway that determines intrasegmental cell fate patterning in the Drosophila embryo (Peifer and Bejsovec 1992; Bejsovec and Wieschaus 1993; Peifer et al. 1994). The mammalian homologues of Wingless are the members of the wnt family of secreted proteins, that appear to have a role in short range signalling over a range of several cell diameters (McMahon 1992). There is evidence that wnt-1 can regulates cadherin function by altering the binding of $\beta$ catenin to cadherin cytoplasmic tails (Bradley et al. 1993; Hinck et al. 1994a; Hinck et al. 1994b). Co-culture of purified stem cell and transit cell populations with wnt secreting fibroblasts will allow the effects of wnt on stem cell patterning to be determined.

\section{Novel stem cell markers}

$\beta_{1}$ integrins are not ideal markers for epidermal stem cells. The difference in integrin expression between bright and dull patches of basal cells is only 2 fold and only 25 $50 \%$ of cells in integrin-bright patches in vivo or in vitro are clonogenic. Anti $\beta_{1}$ integrin antibodies that only recognise the functionally active form of the receptor maybe more specific stem cell markers

The clones obtained by subtractive hybridisation may encode new stem cell markers. They may also include gene products involved in the regulation of stem cell behaviour. The positive clones from the secondary screen will be used to screen Northern blots of poly A RNA from rapidly adherent, slowly adherent and non adherent keratinocytes. If found to be differentially expressed the cDNAs will be sequenced. The function of novel genes could be assayed by retroviral transfection of keratinocytes, followed by organotypic culture of the transfected cells, a technique used to look at proto oncogene function in keratinocytes (A Gandarillias, personal communication). 
The prospects for the study of epidermal stem cells are exciting. New stem cell markers and genes that regulate keratinocyte stem cell behaviour are likely to be discovered. Important questions about stem cell fate decisions that were previously unanswerable can now be addressed. The answers to these questions are likely to yield insights into the function of normal epidermis and the pathogenesis of common diseases such as psoriasis and cancer. 
FIGURE 7.1: Stem cells, transit cells and committed cells in the epidermis

Stem cells shown in dark green, transit cells in light green, committed and differentiating cells in white. Integrin-bright patches contain stem and transit cells, and the integrin-dull patches transit and committed cells. 


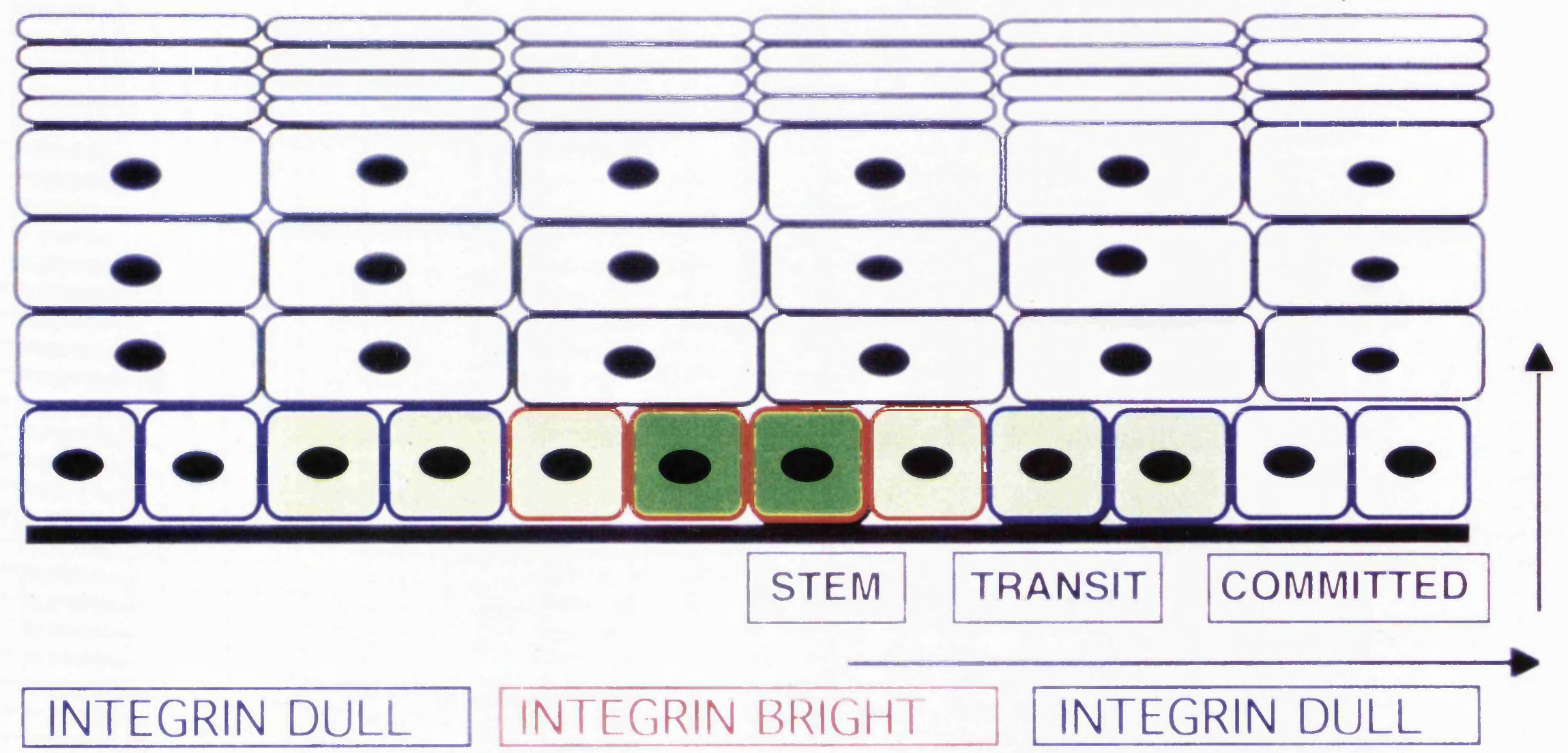


FIGURE 7.2: Possible interactions between integrins, cadherins and the Wnt signalling pathway.

For details see text. 


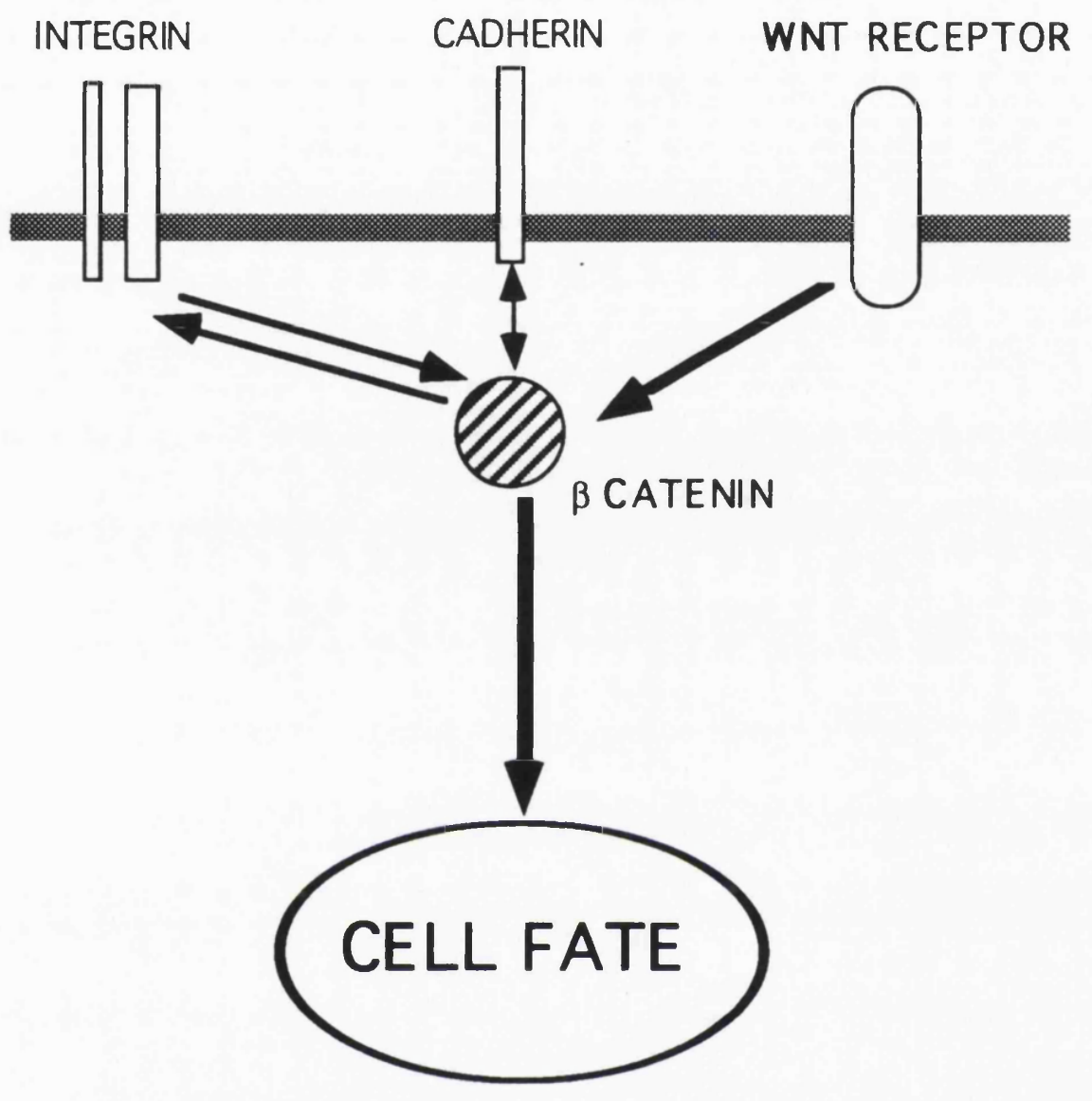




\section{Acknowledgements}

I am very grateful to everyone who has helped me over the 4 years of my research.

Dr Fiona Watt, my external supervisor has been unstinting in her support and encouragement. Her determination always to follow an argument to its logical conclusion has been inspiring. David Hudson has been a constant source of practical advice, friendship and wit. All the past and present members of the keratinocyte lab have helped me with their advice and their encouragement and their friendship. In particular Dr Mark Hertle, Dr Claire Linge, Dr Neil Hotchin, Dr Ed Rytina, Dr Kairbain Hodivala-Dilke, and more recently Dr Jean-Pierre Moles have debated ideas about stem cells.

Outside the Keratinocyte lab, I have to thank the staff in the ICRF FACS laboratory for their advice, in particular Derek Davies, who operated the FACSstar plus cell sorter for me. Peter Jordan taught me about confocal microscopy. Dr Steve Goodbourn, Dr Sebastian Meyer Ewart and Justin Blau guided my first steps in molecular biology. Dr Diana Barnes discussed the merits of different proliferation markers. The in situ hybridisations were carried out by Dr Steve Harper at Leicester General Hospital, who has been a good friend as well as a collaborator. Gill Hutchinson in the ICRF animal unit carried out the mouse surgery. Doug Altman in the ICRF statistics unit gave invaluable advice on statistics and data analysis. Tissue was obtained with the generous assistance of Dr Herbert Barry and Mr S Gluck, and Dr Ed Rytina's colleagues at Guy's Hospital mortuary.

Finally I have to express my thanks my family and Marion for all their love and support. 


\section{BIBLIOGRAPHY}

Aberdam, D., Galliano, M. F., Vailly, J., Pulkkinen, L., Bonifas, J., Christiano, A. M., Tryggvason, K., Uitto, J., Epstein, E., Jr., and Ortonne, J. P. (1994). Herlitz's junctional epidermolysis bullosa is linked to mutations in the gene (LAMC2) for the gamma 2 subunit of nicein/kalinin (LAMININ-5). Nature Genet. 6: 299-304.

Adami, J. G. (1901). The causation of cancerous and other new growths. British Medical Journal. i: 621-628.

Adams, J. C. and Watt, F. M. (1988). An unusual strain of human keratinocytes which do not stratify or undergo terminal differentiation in culture. J Cell Biol. 107: 1927-1938.

Adams, J. C. and Watt, F. M. (1989). Fibronectin inhibits the terminal differentiation of human keratinocytes. Nature, Lond. 340: 307-309.

Adams, J. C. and Watt, F. M. (1990). Changes in keratinocyte adhesion during terminal differentiation: reduction in fibronectin binding precedes $\alpha 5 \beta 1$ integrin loss from the cell surface. Cell. 63: 425-435.

Adams, J. C. and Watt, F. M. (1991). Expression of $\beta 1, \beta 3, \beta 4$, and $\beta 5$ integrins by human epidermal keratinocytes and non-differentiating keratinocytes. J Cell Biol. 115: 829-841.

Adams, J. C. and Watt, F. M. (1993). Regulation of development and differentiation by the extracellular matrix. Development. 117: 1183-1198.

Akiyama, S. K., Yamada, S. S., Chen, W. T. and Yamada, K. M. (1989). Analysis of fibronectin receptor function with monoclonal antibodies: roles in cell adhesion, migration, matrix assembly, and cytoskeletal organisation. J Cell Biol. 109: 863-875.

Albers, K. M., Greif, F., Setzer, R. W. and Taichman, L. B. (1987). Cell-cycle withdrawal in cultured keratinocytes. Differentiation. 34: 236-240.

Albers, K. M., Setzer, R. W. and Taichman, L. B. (1986). Heterogeneity in the replicating population of cultured human epidermal keratinocytes. Differentiation. 31: $134-140$.

Alison, M., Chaudry, Z., Baker, J., Lauder, I. and Pringle, H. (1994). Liver regeneration: a comparison of in situ hybridisation for histone mRNA with bromodeoxyuridine labelling for the detection of $S$ phase cells. J Histochem Cytochem. 42: 1603-1608.

Arch, R., Wirth, K., Hofman, M., Ponta, H., Matzku, S., Herrlich,P., Zoller, M. (1992). Participation in normal immune responses of a metastasis-inducing splice variant of CD44. Science. 257: 682-685.

Archambeau, J. O. (1987). Relative radiation sensitivity of the integumentary system: dose response of the epidermal, microvascular and dermal populations. Advances in radiation biology. Orlando, Academic Press. 147-204. 
Ashley, D. M., Bol, S. J., Waugh, C. and Kannourakis, G. (1993). A novel approach to the measurement of different in vitro leukemic cell growth parameters the use of PKH-GL fluorescent dyes. Lukemia Res. 17: 873-882.

Aviezer, D., Hecht,D.,Safran,M.,Eisinger,M., David,G.and Yayon,A. (1994). Perlecan, basal lamina proteoglycan, promotes basic fibroblast growth factorreceptor binding, mitogenesis and angiogenesis. Cell. 79: 1005-1013.

Baker, H. and Kligman, A. M. (1967). Technique for estimating turnover time in human stratum corneum. Arch Dermatol. 95: 408-411.

Balzac, F., Belkin,A.M., Koteliansky,V.Ė.,Balabanov,Y.V., Altruda,F., Silengo,L.

and Tarone,G. (1993). Expression and functional analysis of a cytoplasmic domain variant of the $\beta 1$ integrin subunit. J Cell Biol. 121: 171-178.

Banks Schlegel, S. and Green, H. (1981). Involucrin synthesis and tissue assembly by keratinocytes in natural and cultured human epithelia. J Cell Biol. 90: 732-737.

Barrandon, Y. and Green, H. (1985). Cell Size as a determinant of the cloneforming ability of human keratinocytes. Proc Natl Acad Sci U S A. 82: 53905394.

Barrandon, Y. and Green, H. (1987a). Cell migration is essential for sustained growth of keratinocyte colonies: the roles of transforming growth factor- $\alpha$ and epidermal growth factor. Cell. 50: 1131-1137.

Barrandon, Y. and Green, H. (1987b). Three clonal types of keratinocyte with different capacities for multiplication. J Cell Biol. 84: 2302-2306.

Barrandon, Y., Li, V. and Green, H. (1988). New techniques for the grafting of cultured human epidermal cells onto athymic animals. J Invest Dermatol. 91: 315318.

Barrandon, Y., Morgan, J. R., Mulligan, R. C. and Green, H. (1989). Restoration of growth potential in paraclones of human keratinocytes by a viral oncogene. Proc Natl Acad Sci U S A. 86: 4102-4106.

Barres, B. A., Lazar, M. A. and Raff, M. C. (1994). A novel role for thyroid hormone, glucocorticoids and retinoic acid in the timing of oligodendrocyte development. Development. 120: 1097-1108.

Barres, B. A. and Raff, M. C. (1994). Control of oligodendrocyte number in the developing rat optic nerve. Neuron. 12: 935-942.

Becker, A. J., McCulloch, E. A. and Till, J. E. (1963). Cytological demonstration of the clonal nature of spleen colonies derived from transplanted mouse marrow cells. Nature. 197: 452-454.

Becker, A. J., McCulloch, E. A. and Till, J. E. (1965). The effect of differing demands for blood cell production on DNA synthesis by hemopoietic colonyforming cells of mice. Blood. 26: 296-308. 
Bejsovec, A. and Wieschaus, E. (1993). Segment polarity gene interactions modulate epidermal patterning in drosophila embryos. Development. 119: 501507.

Belkin, V. M., Belkin, A. M. and Koteliansky, V. E. (1990). Human smooth muscle VLA-1 integrin: purification, substrate specificity, localisation in aorta, and expression during development. J Cell Biol. 111: 2159-2170.

Benson, M., McDougal, D. C. and Coffey, D. S. (1984). The application of perpendicular and forward light scatter to assess nuclear and cellular morphology. Cytometry. 5: 515-522.

Bereiter-Hahn, J. (1986). Epidermal cell migration and wound repair. Biology of the integument. 2. Vertebrates. Berlin, Springer-Verlag. 443-471.

Berenblum, I. (1954). A speculative review: the probable nature of promoting action and its significance in the understanding of the mechanism of carcinogenesis. Cancer Research. 14: 471-477.

Beverly, P. C. L. and Callard, R. D. (1981). Distinctive functional characteristics of human 'T' lymphocytes. Eur J Immunol. 11: 329-334.

Bickenbach, J. R. (1981). Identification and behaviour of label retaining cells in oral mucosa and skin. J Dental Res. 60: 1620-1622.

Bossy, B., Bossy-Wetzel, E. and Reichardt, L. F. (1991). Characterisation of the integrin $\alpha 8$ subunit: a new integrin $\beta 1$-associated subunit, which is prominently expressed on axons and on cells in contact with basal laminae in chick embryos. EMBO J. 10: 2375-2385.

Boyd, F. T. (1993). Identification of growth inhibited cells by retention of a lipophillic fluorescent dye. Cell Growth and differentiation. 4: 777-784.

Bradley, R. S., Cowin, P. and Brown, A. M. C. (1993). Expression of Wnt-1 in PC12 cells results in modulation of plakoglobin and E-cadherin and increased cellular adhesion. The Journal of Cell Biology. 123: 1857-1865.

Brandt, J., Baird, N., Lu, L., Srour, E. and Hoffman, R. (1988). Characterization of a human hematopoietic progenitor cell capable of forming blast cell containing colonies in vitro. J Clin Invest. 82: 1017-1027.

Briggaman , R. and Wheeler, C. E. J. (1975). The epidermal-dermal junction. J Invest Dermatol. 65: 71-84.

Briggaman, R. A., Yoshiike, T. and Cronce, D. J. (1991). The Epidermal-Dermal Junction and Genetic Disorders of this Area. Physiology, Biochemistry and Molecular Biology of the Skin. Ed. Goldsith L.A. Oxford, Oxford University Press. 2nd ed. p1243-1266.

Buck, C., Albelda, S., Damjanovich, L., Edelman, J., Shih, D. T. and Solowska, J. (1990). Immunohistochemical and molecular analysis of $\beta 1$ and $\beta 3$ integrins. Cell Differ Dev. 32: 189-202.

Burgeson, R. E. (1993). Type VII collagen, anchoring fibrils and epidermolysis bullosa. J Invest Dermatol. 101: 252-255. 
Burgeson, R. E., Chiquet, M., Deutzman, R., Eckblom, P., Engel, J., Kleinman, H., Martin, G. R., Meneguzzi, G., Paulsson, M., Sanes, J., Timpl, R., Tryggvason, K., Yamada, Y. and Yurchenco, P. D. (1994). A new nomenclature for laminins. Matrix Biol. 14: 209-211.

Cairns, J. (1975). Mutational selection and the natural history of cancer. Nature. 255: $197-200$.

Carter, W. G., Kaur, P., Gil, S. G., Gahr, P. J. and Wayner, E. A. (1990). Distinct functions for integrins $\alpha 3 \beta 1$ in focal adhesions and $\alpha 6 \beta 4 /$ bullous pemphigoid antigen in a new stable anchoring contact (SAC) of keratinocytes: relation to hemidesmosomes. J Cell Biol. 111: 3141-3154

Carter, W. G., Ryan, M. C. and Gahr, P. J. (1991). Epiligrin, a new cell adhesion ligand for integrin $\alpha 3 \beta 1$ in epithelial basement membranes. Cell. 65: 599-610.

Carter, W. G., Wayner, E. A., Bouchard, T. S. and Kaur, P. (1990). The role of integrins $\alpha 2 \beta 1$ and $\alpha 3 \beta 1$ in cell-cell and cell-substrate adhesion of human epidermal cells. J Cell Biol. 110: 1387-1404.

Castoldi, G. 1. and Beutler, E. (1988). Erythrocytes. Atlas of blood cells. Philadelphia, Lea and Febiger. 2, ed. 47-156.

Caughman, S. W., Kreig, T., Timpl, R., Hinter, H. and Katz, S. I. (1987). Nidogen and heparan sulpate proteoglycan: detection of newly isolated basement membrane components in normal and epidermolysis bullosa skin. J Invest Dermatol. 89: 547-550.

Chacko, L. W. and Vaidya, M. C. (1968). The dermal papillae and ridge patterns in human volar skin. Acta Anat. 70: 99-108.

Chan, F. L., Inoue, S. and Leblond, C. P. (1993). The basement membranes of cryofixed or aldehyde-fixed, freeze -substituted tissues are composed of a lamina densa and do not contain a lamina lucida. Cell Tissue Res. 273: 41-52.

Chapman, R. E. (1986). Hair, wool, quill, nail, claw, hoof and horn. Biology of the integument. 2. Vertebrates. Berlin, Springer-Verlag. 293-317.

Charbord, P. (1994). Hemopoietic stem cells: analysis of some parameters critical for engraftment. Stem Cells. 12: 545-562.

Chen, F. A., Repasky, E. A. and Bankert, R. B. (1991). Human lung tumour associated antigen identified as an extracellular matrix adhesion molecule. J Exp Med. 173: 1111-1119.

Cheng, J., Syder, A. J., Yu, Q-C., Letai, A.,Paller, A., Fuchs, E. (1992). The genetic basis of epidermolytic hyperkeratosis, a disorder of differentiation-specific keratin genes. Cell. 70: 811-819.

Chervenick, P. A., Zucker-Franklin, D. and Moore, M. A. S. (1988). In vitro and in vivo hematopoiesis. Atlas of blood cells. Philadelphia, Lea and Febiger. 2, ed. 346.

Choi, Y. and Fuchs, E. (1990). TGF- $\beta$ and retinoic acid: regulators of growth and modifiers of differentiation in human epidermal cells. Cell Regul. 1: 791-809.

Church, G. M. and Gilbert, W. (1984). Genomic sequencing. Proc Natl Acad Sci U.S.A. 81: 1991-1995. 
Compton, C. C. (1992). Current concepts in pediatric burn care - the biology of cultured epithelial autografts- an 8 year study in pediatric burns patients. Eur $\mathbf{J}$ Pediatric Surgery. 2: 216-222.

Compton, C. C. (1993). Wound-healing potential of cultured epithelium. Wounds. 5: $97-111$.

Compton, C. C., Gill, J. M., Bradford, D. A., Regauer, S., Gallico, G. G., and O'Connor, N. E. (1989). Skin regenerated from cultured epithelial autografts on full-thickness burn wounds from 6 days to 5 years after grafting. A light, electron microscopic and immunohistochemical study. Lab Invest. 60: 600-12.

Cooper, Z. K. and Franklin, H. C. (1938). Mitotic rhythms in human epidermis. Proc Soc Exp Biol Med. 39: 323-324.

Cotsarelis, G., Cheng, S.-Z., Dong, G., Sun, T.-T. and Lavker, R. M. (1989). Existence of slow cycling limbal epithelial basal cells that can be preferentially stimulated to proliferate: implications on epidermal stem cells. Cell. 57: 201-209.

Cotsarelis, G., Sun, T.-T. and Lavker, R. M. (1990). Label-retaining cells reside in the bulge area of pilosebaceous unit: implications for follicular stem cells, hair cycle, and skin carcinogenesis. Cell. 61: 1329-1337.

Couchman, J. R., Austria, M. R. and Woods, A. (1990). Fibronectin-cell interactions. J Invest Dermatol. 94: 7S-14S.

Coulombe, P. A., Kopan, R. and Fuchs, E. (1989). Expression of keratin 14 in the epidermis and hair follicle: insights into complex programs of differentiation. J Cell Biol. 109: 2295-2312.

Cowin, P. (1994). Intercellular Junctions. In The keratinocyte handbook. Eds Leigh, I. M., Lane, E. B. and Watt, F. M. Cambridge, Cambridge University Press. p165-180.

Cowin, P., Kapprell, H.-P., Franke, W. W., Tamkun, J. and Hynes, R. O. (1986). Plakoglobin: a protein common to different kinds of intercellular adhering junctions. Cell. 46: 1063-1073.

Curry, J. L. and Trentin, J. J. (1967). Hemopoietic spleen colony studies 1. Growth and differentiation. Devl Biol. 15: 395-413.

D'Andrea, A. D. (1994). Hematopoietic growth factors and the regulation of differentiative decisions. Curr Opinion in Cell Biology. 6: 804-808.

D'Souza, S. E., Haas, T.A., Piotrowicz, R. S., Byers-Ward, V., Mcgrath, D. E., Soule, H. R., Cierniewski, C., Plow, E. F., and Smith, J .S.(1994). Ligand and cation binding are dual functions of a discrete segment of the integrin $\beta 3$ subunit: cation displacement is involved in ligand binding. Cell. 79: 659-667.

Dale, B. A., Resing, K. A. and Presland, R. B. (1994). Keratohyalin granule proteins. In The keratinocyte handbook. Eds Leigh, I. M., Lane, E. B. and Watt, F. M.Cambridge, Cambridge University Press. p323-350.

De Luca, M., Tamura, R. N., Kajiji, S., Bondanza, S., Rossino, P., Cancedda, R., Marchisio, P. C. and Quaranta, V. (1990). Polarised integrin mediates human keratinocyte adhesion to basal lamina. Proc Nat Acad Sci U S A. 87: 6888-6892. 
De Strooper, B., Saison, M., Jaspers, M., Spaepen, M., Van Leuven, F., Van den Berghe, H. and Cassiman, J.-J. (1988). Monoclonal antibody DH12 reacts with a cell surface and a precursor form of the $\beta$ subunit of the human fibronectin receptor. Cell Biol Int Rep. 12: 9-16.

Del Sal, G., Ruaro, M. E., Philipson, L. and Schneider, C. (1992). The growth arrest-specific gene, gas 1 , is involved in growth supression. Cell. 70: 595-607.

Dominey, A. M., Wang, X.-J., King, L. E. J., Nanney, L. B., Gagne, T. A., Sellheyer, K., Bundman, D. S., Greeenhalgh, D. A. and Roop, D. R. (1993). Targeted overexpression of transforming growth factor alpha in the epidermis of transgenic mice elicits hyperplasia, hyperkeratosis and spontaneous, squamous papillomas. Cell Growth and differentiation. 4: 1071-1082.

Dover, R. (1994). Cell kinetics of epidermis. In The keratinocyte handbook. Eds Leigh, I. M., Lane, E. B. and Watt, F. M. Cambridge, Cambridge University Press. p 203-234.

Dover, R. and Potten, C. S. (1983). Cell Cycle Kinetics of Cultured Human Epidermis. J Invest Dermatol. 80: 423-429.

Dover, R. and Potten, C. S. (1988). Heterogeneity and cell cycle analyses from time-lapse studies of human keratinocytes in vitro. J Cell Sci. 89: 359-364.

Dover, R. and Watt, F. M. (1987). Measurement of the Rate of Epidermal Terminal Differentiation: Expression of Involucrin by $S$ phase Keratinocytes in culture and in Psoriatic Plaques. J Invest Dermatol. 89: 349-352.

Ebling, F. J. G., Hale, P. A. and Randall, V. A. (1991). Hormones and hair growth. Physiology. Biochemistry and Molecular Biology of the Skin. Ed. Goldsmith L. A. Oxford, Oxford University Press. 2nd ed. p660-696.

El-Deiry, W. S., Tokino, T., Velculescu, V. E., Levy, D. B., Parsons, R., Trent, J. M., Lin, D., Mercer, W. E., Kinzler, K. W. and Vogelstein, B. (1993). WAF1, a potential mediator of p53 tumour suppression. Cell. 75: 817-825.

Epstein, W. L. and Maibach, H. I. (1965). Cell renewal in human epidermis. Arch Dermatol. 92: 462-468.

Ewing, J. S. (1907). Cancer problems. Harvey Lectures. 3: 34-88.

Fairburn, L. J. and Cowling, G. J. (1993). Suppression of apoptosis allows differentiation and development of a multipotent hemopoietic cell line in the absence of growth factor. Cell. 74: 823-832.

Fava, R. A. and McClure, D. B. (1987). Fibronectin associated transforming growth factor. J Cell Physiol. 131: 184-189.

Flanagan, J. G., Chan, D. C. and Leder, P. (1991). Transmembrane form of the kit ligand growth factor is determined by alternative splicing and is missing in the $\mathrm{Sl}^{\mathrm{d}}$ mutant. Cell. 64: 1025-1035.

Fleischmayer, R. and Timpl, R. (1984). Ultrastructural localisation of fibronectin to different anatomic structures of the human skin. J Histochem Cytochem. 32: 315321. 
Foidart, J. M. and Yaar, M. (1981). Type IV collagen, laminin and fibronectin at the dermo-epidermal junction. Front Matrix Biol. 9: 175-188.

Ford, C. E., Hamerton, J. L. and Loutit, J. F. (1956). Cytological identification of radiation chimeras. Nature. 177: 452-454.

Fox, J. W., Mayer, U., Nischt, R., Aumailley, M., Rheinhardt, D., Weideman, H., Mann, K., Timpl, R., Kreig, T., Engel, J. and Chu, M.-L. (1991).

Recombinant nidogen consists of 3 globular domains and mediates binding of laminin to collagen type IV. EMBO J. 10: 3137-3146.

Fuchs, E. (1990). Epidermal Differentiation: the bare essentials. J Cell Biol. 111: 2807-2814.

Fuchs, E. (1994). Intermediate filaments and disease: mutations that cripple cell strength. J Cell Biol. 125: 511-516.

Fuchs, E. and Byrne, C. (1994). The epidermis: rising to the surface. Current Opinion in Cell Biology. 6: 725-736.

Funk, P. E., Kincade, P. W. and Witte, P. L. (1994). Native associations of early hematopoietic stem cells and stromal cells isolated in bone marrow aggregates.

Blood. 83: 361-369.

Gallico III, G. G., O'Connor, N. E., Compton, C. C., Kehinde, O. and Green, H. (1984). Permanent coverage of large skin wounds with autologous cultured epithelium. New Engl J Med. 311: 448-451.

Gates, R. E., King, L. E., Hanks, S. K. and Nanney, L. B. (1994). Potential role for focal adhesion kinase in migrating and proliferating keratinocytes near epidermal wounds and in culture. Cell Growth and Differentiation. 5: 891-899.

Geiger, B. and Ayalon, O. (1992). Cadherins. Annual Review Cell Biol. 8: 307322 .

Germain, L., Rouabhia, M., Guignard, R., Carrier, L., Bouvard, V. and Auger, F. A. (1993). Improvement of human keratinocyte isolation and culture using thermolysin. Burns. 19: 99-104.

Gerrard, A. J., Hudson, D. L., Brownlee, G. G. and Watt, F. M. (1993). Towards gene therapy for haemophilia B using primary human keratinocytes. Nature Genetics. 3: 180-183.

Goding, J. W. (1976). Conjugation of antibodies to fluorochrome: modifications to the standard methods. J Immunol Methods. 13: 215-226.

Green, H. (1977). Terminal Differentiation of cultured human epidermal cells. Cell. 11: 405-416.

Green, H. (1978). Cyclic AMP in relation to proliferation of the epidermal cell: a new view. Cell. 15: 801-11.

Greenhalgh, D. A., Rothnagel, J. A. and Roop, D. R. (1994). Epidermis: an attractive target tissue for gene therapy. J Invest Dermatol. 103: 63S-69S. 
Gregory, C. J. and Eaves, A. C. (1977). Three stages of erythropoietic progenitor cell differentiation distinguished by a number of physical and biological properties. Blood. 51: 527-537.

Gretch, D. R., Suter, M. and Stinski, M. F. (1987). The use of biotinylated monoclonal antibodies and streptavidin affinity chromatography to isolate Herpesvirus hydrophobic proteins or glycoproteins. Anal Biochem. 163: 270-277.

Grinnell, F. (1992). Wound repair, keratinocyte activation and integrin modulation. J Cell Sci. 101: 1-5.

Guo, L., Yu, Q.-C. and Fuchs, E. (1993). Targeting expression of keratinocyte growth factor to keratinocytes elicits striking changes in epithelial differentiation of transgenic mice. EMBO J. 12: 973-986.

Haake, A. R. and Polakowska, R. R. (1993). Cell death in epidermal biology. J Invest Dermatol. 101: 107-112.

Haas, T. A. and Plow, E. F. (1994). Integrin ligand interactions: a year in review. Current Opinion in Cell Biology. 6: 656-662.

Hafen, E., Dickson, B., Raabe, T., Brunner, D., Oellers, N. and van der Straten, A. (1993). Genetic analysis of the sevenless signal transduction pathway or drosophila. Development. Supplement: 41-46.

Hall, P. A., Levison, D. A., Woods, A. L., Yu, C. C.-W., Kellock, D. B., Watkins, J. A., Barnes, D. M., Gillet, C. E., Camplejohn, R., Dover, R., Wassem, N. H. and Lane, D. P. (1990). Proliferating cell nuclear antigen (PCNA) immunolocalization in paraffin sections: an index of cell proliferation with evidence of deregulated expression in some neoplasms. J Pathol. 162: 285-294.

Hall, P. A., Mckee, P. H., Menage, H. D. P., Dover, R. and Lane, D. P. (1993). High levels of p53 protein in UV-irradiated normal human skin. Oncogene. 8: 203207.

Ham, A. W. and Cormack, D. H. (1979). Histology. Philadelphia, J B Lippincott.

Hampson, I. N., Pope, L., Cowling, G. J. and Dexter, T. M. (1992). Chemical cross linking subtraction (CCLS): a new method for the generation of subtraction hybridisation probes. Nucleic Acids Res. 20: 2899.

Hanahan, D. (1983). Studies on the transformation of escherichia coli with plasmids. J Mol Biol. 166: 557-580.

Harlow, E. and Lane, D. (1988). Antibodies: a laboratory manual. New York, Cold Spring Harbour Laboratory.

Hassel, J. R., Kimura, J. H. and Hascall, V. C. (1986). Proteoglycan core protein families. Ann Rev Biochem. 55: 539-567.

Hauser, C., Elbe, A. and Stingl, G. (1991). The Langerhans cell. In The physiology, biochemistry and molecular biology of the skin. Ed. Goldsmith L.A. Oxford, Oxford University Press. 2nd ed. p1144-1163. 
Hemler, M. E., Elices, M. J., Chan, B. M., Zetter, B., Matsuura, N. and Takada, Y. (1990). Multiple ligand binding functions for VLA-2 ( $\alpha 2 \beta 1)$ and VLA-3 ( $\alpha 3 \beta 1)$ in the integrin family. Cell Differ Dev. 32: 229-238.

Hemler, M. E., Weitzman, J. B., Pasqualine, R., Kawaguchi, S., Kassner, P. D. and Berdichevski, F. B. (1994). Structure, biochemical properties, and biological functions of integrin cytoplasmic domains. Integrins: the biological problems. Boca Raton, CRC Press. 2-35.

Hennings, H., Glick, A. B., Greenhalgh, D. A., Morgan, D. L., Strickland, J. E., Tennenbaum, T. and Yuspa, S. H. (1993). Critical aspects of initiation, promotion and progression in multistage epidermal carcinogenesis. Proc Soc Exp Biol. 202: $1-18$.

Hertle, M. D., Adams, J. C. and Watt, F. M. (1991). Integrin expression during human epidermal development in vivo and in vitro. Development. 112: 193-206.

Hertle, M. D., Kubler, M. D., Leigh, I. M. and Watt, F. M. (1992). Aberrant integrin expression during epidermal wound healing and in psoriatic epidermis. $J$ Clin Invest. 89: 1892-1901.

Hibbs, R. G. and Clark, W. H. (1959). Electron microscope studies of the human epidermis. The cell boundaries and topography of the stratum malphigi. J Biophys Biochem Cytol. 6: 71-76.

Hinck, L., Nathke, I. S., Papkoff, J. and Nelson, W. J. (1994a). Dynamics of cadherin / catenin complex formation: novel protein interactions and pathways of complex assembly. The Journal of Cell Biology. 125: 1327-1340.

Hinck, L., Nelson, J. W. and Papkoff, J. (1994b). Wnt-1 modulates cell-cell adhesion in mammalian cells by stabilizing $\beta$-catenin binding to the cell adhesion protein cadherin. The Journal of Cell Biology. 124: 729-741.

Hodivala, K. J. and Watt, F. M. (1994). Evidence that cadherins play a role in the downregulation of integrin expression that occurs during keratinocyte terminal differentiation. J Cell Biol. 124: 589-600.

Holbrook, K. and Hennings, H. (1983). Keratinocyte Ultrastructure in vitro. J Invest Dermatol. 81: 11s-24s.

Holbrook, K. A. (1994). Ultrastructure of the epidermis. The keratinocyte handbook. Eds Leigh, I. M., Lane, E. B. and Watt, F. M. Cambridge, Cambridge University Press. p3-39.

Holbrook, K. A. and Odland, G. F. (1974). Regional differences in the thickness (cell layers) of human stratum corneum: an ultrastructural analysis. J Invest Dermatol. 62: 15-22.

Holbrook, K. A., Smith, L. T., Kaplan, E. D., Minami, S. A., Hebert, G. P. and Underwood, R. A. (1993). Expression of morphogens during human follicle development in vivo and a model for studying morphogenesis in vitro. J Invest Dermatol. 101, supplement: 39S-49S.

Horan, P. (1990). Fluorescent cell labeling for in vivo and in vitro cell tracking. Flow cytometry. Academic Press. 33: 469. 
Hotchin, N. A., Kovach, N. L. and Watt, F. M. (1993). Functional down regulation of integrins is reversible but commitment to terminal differentiation is not. J Cell Sci. 106: 1131-1138.

Hotchin, N. A. and Watt, F. M. (1992). Transcriptional and post-translational regulation of $\beta 1$ integrin expression during keratinocyte terminal differentiation. $J$ Biol Chem. 267: 14852-14858.

Hsu, S.-M. and Soban, E. (1982). Color modification of Diaminobenzidine (DAB) precipitation by metallic ions and its application for double immunohistochemistry. J Histochem Cytochem. 30: 1079-1082.

Hudson, D. H. and Watt, F. M. (In press). CD44 is the major peanut lectin binding protein of keratinocytes and plays á role in cell-cell adhesion. J Cell Science.

Hudson, D. L., Weiland, K. L., Dooley, T. P., Simon, M. and Watt, F. M. (1992). Characterisation of eight monoclonal antibodies to involucrin. Hybridoma. 11: $367-379$.

Hynes, R. O. (1989). Fibronectins. New York, Springer Verlag.

Hynes, R. O. (1992). Integrins: versatility, modulation, and signalling in cell adhesion. Cell. 69: 11-25.

Isacke, C. M. (1994). The role of the cytoplasmic domain in regulating CD44 function. J Cell Sci. 107: 2353-2359.

Jakic-Razumovic, J., Browne, M. D. and Sale, G. E. (1992). Proliferation rates in epidermis of patients with graft versus-host disease, non specific inflammation and normal skin. Bone marrow transplant. 10: 27-31.

Jansen, L. H., Hojyo-Tomoko, M. T. and Kligman, A. M. (1974). Improved fluorescence staining technique for estimating turnover of the human stratum corneum. Br J Dermatol. 90: 9-12.

Jimbow, K., Fitzpatrick, T. B. and Wick, M. M. (1991). Biochemistry and physiology of melanin pigmentation. Physiology, biochemistry and molecular biology of the skin. Ed Goldsmith L.A. Oxford, Oxford University Press. 2nd. p873-909.

Johnson, R. P. and Craig, S. W. (1995). F-actin binding site masked by the intramolecular association of vinculin head and tail domains. Nature. 373: 261 264.

Jones, P. H., Harper, S. and Watt, F. M. (1995). Stem cell fate and patterning in human epidermis. Cell. 80: 83-93.

Jones, P. H. and Watt, F. M. (1993). Separation of human epidermal stem cells from transit amplifying cells on the basis of integrin expression and function. Cell. 73: 713-724.

Jones, P. H. and Watt, F. M. (1994). Applications of flow cytometry in the study of keratinocytes. Keratinocyte Methods. Eds Leigh, I. M., Lane, E. B. and Watt, F. M.Cambridge, Cambridge University Press. p105-111. 
Kaiser, H. W., Ness, W., Jungblut, I., Briggaman, R. A., Kreysel, H. W. and O'Keefe, E. O. J. (1993). Adherens junctions: demonstration in human epidermis. J Invest Dermatol. 100: 180-185.

Karasek, J. (1988). Nuclear morphology of transitional keratinocytes in normal human epidermis. J Invest Dermatol. 91: 243-246.

Kassner, P. D. and Hemler, M. E. (1993). Interchangeable $\alpha$-chain cytoplasmic domains play a positive role in control of cell-adhesion mediated by vla-4, a $\beta(1)$ integrin. J Exp Med. 178: 649-660.

Kaufmann, R., Frosch, D., Westphal, C., Weber, L. and Klein, C. E. (1989). Integrin VLA-3: ultrastructural localization at cell-cell contact sites of human cell cultures. J Cell Biol. 109: 1807-1815.

Kawaguchi, S. and E., H. M. (1993). Role of the $\alpha$-subunit cytoplasmic domain in regulation of adhesive activity mediated by the integrin vla-2. J Biol Chem. 268: $16279-16285$.

Kealy, T. and Philpot, M. P. (1994). Human pilosebaceous culture: the background. In The keratinocyte handbook. Eds Leigh, I. M., Lane, E. B. and Watt, F. M. Cambridge, Cambridge University Press. p 102-129.

Keeble, S. and Watt, F. M. (1990). Characterisation of the peanut lectin binding glycoproteins of human epidermal keratinocytes. Differentiation. 43: 139-145.

Keene, D. R., Sakai, L. Y., Lunstrum, G. P., Morris, N. P. and Burgeson, R. E. (1987). Type VII collagen forms an extended network of anchoring fibrils. J Cell Biol. 104: 611-621.

Kerker (1983). Elastic and Inelastic light scattering in Flow Cytometry. Cytometry. 4: $1-10$.

Kerr, J. F. R., Wyllie, A. H. and Currie, A. R. (1972). Apoptosis: a basic biological phenomenon with widespread clinical applications. $\mathrm{Br} \mathrm{J}$ Cancer. 26: 239-257.

Kirchhofer, D., Gailit, J., Ruoslahti, E., Grzesiak, J. and Pierschbacher, M. D. (1990). Cation-dependent changes in the binding specificity of the platelet receptor GPIIb/IIIa. J Biol Chem. 265: 18525-18530.

Kirchhofer, D., Grzesiak, J. and Pierschbacher, M. D. (1991). Calcium as a potential physiological regulator of integrin-mediated cell adhesion. J. Biol. Chem. 266: 4471-4477.

Kirchhofer, D., Languino, L. R., Ruoslahti, E. and Pierschbacher, M. D. (1990). $\alpha 2 \beta 1$ integrins from different cell types show different binding specificities. J Biol Chem. 265: 615-618.

Kjellen, L. and Lindahl, U. (1991). Proteoglycans: structures and interactions. Ann Rev Biochem. 60: 443-447.

Kobayashi, K., Rochat, A. and Barrandon, Y. (1993). Segregation of keratinocyte colony-forming cells in the bulge of the rat vibrissa. Proc Natl Acad Sci U S A. 90: 7391-7395. 
Koenigsmann, M., Griffin, J. D., DiCarlo, J. and Cannistra, S. A. (1992). Myeloid and Erythroid Progenitor Cells From Normal Bone Marrow Adhere to Collagen Type 1. Blood. 79: 657-665.

Kovach, N. L., Carlos, T. M., Yee, E. and Harlan, J. M. (1992). A monoclonal antibody to $\beta 1$ integrin (CD29) stimulates VLA-dependent adherence of leukocytes to human umbilical vein endothelial cells and matrix components. J Cell Biol. 116: 499-509.

Kovach, N. L., Lin, N., Yednock, T., Harlan, J. M. and Broudy, V. C. (1995).

Stem cell factor modulates activity of $\alpha 4 \beta 1$ and $\alpha 5 \beta 1$ integrins expressed on haemopoietic cell lines. Blood. 85: 159-167.

Kriegler, M. (1990). Gene expression and transfer - a laboratory manual. New York, Stockton Press.

Krishan, A. (1975). Rapid flow cytometric analysis of mammalian cell cycle by propidium iodide staining. J Cell Biol. 66: 188-193.

Kubler, M. D. and Watt, F. M. (1993). Changes in the distribution of actin -associated proteins during epidermal wound healing. J Invest Dermatol. 100: 785789.

Lajtha, L. G. (1979). Stem cell concepts. Differentiation. 14: 23-24.

Lammeli, U. K. (1970). Cleavage of structural proteins during the assembly of the head of bacteriophage T4. Nature. 227: 680-685.

Lane, E. B. and Alexander, C. M. (1990). Use of keratin antibodies in tumour diagnosis. Seminars in Cancer Biology. 1: 165-179.

Lane, E. B., Rugg, E. L., Navisaria, H., Leigh, I. M., Heagerty, A. H. M., Ishada-Yamamoto, A. and Eady, R. A. J. (1992). A mutation in the conserved helix termination peptide of keratin 5 in hereditary skin blistering. Nature. 356: 244246.

Lane, E. B., Wilson, C. A., Hughes, B. R. and Leigh, I. M. (1991). Stem cells in hair follicles. Cytoskeletal studies. Annals NY Acad Sci. 642: 197-213.

Larjava, H., Peltonen, J., Akiyama, S. K., Yamada, S. S., Gralnick, H. R., Uitto, J. and Yamada, K. M. (1990). Novel function for $\beta 1$ integrins in keratinocyte cellcell interactions. J Cell Biol. 110: 803-815.

Lavker, R. M. and Sun, T.-T. (1982). Heterogeneity in Epidermal Basal Keratinocytes: Morphological and Functional Correlations. Science. 215: 12391241.

Lavker, R. M. and Sun, T.-T. (1983). Epidermal stem cells. J Invest Dermatol. 81: 121S-127S.

Lee, E.C., Lotz, M.M., Steele, G.D. and Mercurio, A.M. (1992). The integrin $\alpha 6 \beta 4$ is a laminin receptor. J Cell Biol. 117: 671-678.

Legan, P. K., Collins, J. E. and Garrod, D. R. (1992). The molecular biology of desmosomes and hemidesmosomes: "What's in a name?". Bioessays. 14: 385393. 
Leigh, I. M. and Watt, F. M. (1994). The culture of human epidermal keratinocytes. In The keratinocyte handbook. Eds Leigh, I. M., Lane, E. B. and Watt, F. M.Cambridge, Cambridge University Press. p43-51.

Lever, W. F. and Schaumberg -Lever, G. (1983). Histopathology of the skin. Philadelphia, Lippincott.

Liang, P., Averboukh, L. and Pardee, A. B. (1993). Distribution and cloning of eukaryotic mRNAs by means of differential display: refinements and optimization. Nucleic Acids Research. 21: 3269-3275.

Liang, P. and Pardee, A. B. (1992). Differential display of eukaryotic messenger RNA by means of the polymerase chain reaction. Science. 257: 967-971.

Lotan, R., Suktelsky, E., Danon, D. and Sharon, N. (1975). The purification, composition, and specificity of the anti-T lectin from peanut (arachis hypogaea). J Biol Chem. 250: 8518-8523.

Luna, E. J. and Hitt, A. L. (1992). Cytoskeleton-plasma membrane interactions. Science. 258: 955-964.

Mackenzie, I. C. (1970). Relationship between mitosis and the ordered structure of the stratum corneum in mouse epidermis. Nature. 26: 653-655.

Mackenzie, I. C., Zimmerman, K. and Peterson, L. (1981). The pattern of cellular organisation in human epidermis. J Invest Dermatol. 76: 459-461.

Magee, A. I., Lytton, N. A. and Watt, F. M. (1987). Calcium-induced changes in cytoskeleton and motility of cultured human keratinocytes. Exp Cell Res. 172: 4353.

Marchisio, P. C., Cancedda, R. and De, L. M. (1990). Structural and functional studies of integrin receptors in cultured human keratinocytes. Cell Differ Dev. 32: 355-359.

Marinkovich, M. P., Keene, D. R., Rimberg, C. S. and Burgeson, R. E. (1993). Cellular origin of the dermal-epidermal basement membrane. Dev Dyn. 197: 25567.

Marinkovitch, P. M., Lunstrum, G. P., Keene, D. R. and Burgeson, R. E. (1992). The dermal epidermal junction of human skin contains a novel variant laminin. $J$ Cell Biol. 119: 695-703.

McCall, C. A. and Cohen, J. J. (1991). Programmed cell death in terminally differentiating keratinocytes: role of endogenous endonuclease. J Invest Dermatol. 97: 111-114.

McMahon, A. P. (1992). The Wnt family of developmental regulators. Trends in Genetics. 8: 236-242.

Messenger, A. G., Elliot, K., Temple, A. and Randall, V. A. (1991). Expression of basement membrane proteins and interstitial collagens in dermal papillae of human hair follicles. J Invest Dermatol. 96: 93-97.

Metcalf, D. (1984). The hemopoietic colony stimulating factors. Amsterdam, Elsevier. 
Metcalf, D. (1992). The hemopoietic regulators - an embarrassment of riches. BioEssays. 14: 799-805.

Metcalf, D. (1993). Hematopoietic regulators: redundancy or subtlety. Blood. 82: 3515-3523.

Mihara, M., Miura, M., Suyama, Y. and Shimao, S. (1992). Scanning electron microscopy of the epidermal lamina densa in normal human skin. J Invest Dermatol. 99: 572-578.

Milstone, L. M., Hough-Monroe, L., Kugelman, L. C., Bender, J. R. and Haggerty, J. G. (1994). Epican, a heparan/chondroitin sulphate proteoglycan form of CD44, mediates cell-cell adhesion. J Cell Science. 107: 3183-3190.

Miyake, K., Weissman, I. L., Greenberger, J. S. and Kincade, P. W. (1991). Evidence for a role of the integrin VLA-4 in lympho-hemopoiesis. J Exp Med. 173: 599-607.

Morely, S. M. and Lane, E. B. (1994). The keratinocyte cytoskeleton. The keratinocyte handbook. Eds Leigh, I. M., Lane, E. B. and Watt, F. M. Cambridge, Cambridge University Press. p 293-321.

Morisson-Graham, K. and Takahashi, Y. (1993). Steel factor and c-kit receptor from mutants to a growth factor system. Bioessays. 15: 77-83.

Morrison, A., Keeble, S. and Watt, F. M. (1988). The Peanut Lectin-Binding Glycoproteins of Human Epidermal Keratinocytes. Exp Cell Research. 177: 247256.

Mullaney, P. F. and Dean, P. N. (1970). The Small Angle light Scattering of Biological Cells. Biophysical J. 10: 764-772.

Munger, B. L. (1991). The biology of Merkel cells. Physiology, biochemistry and molecular biology of the skin. Ed Goldsmith, L.A. Oxford, Oxford University Press. 2, ed. 836-856.

Murdoch, A. D., Liu, B., Schwarting, R., Tuan, R. S. and Iozzo, R. V. (1994). Widespread expression of perlecan proteoglycan in basement membranes and extracellular matrices of human tissues as detected by a novel monoclonal antibody against domain III and in situ hybridisation. J Histochem Cytochem. 42: 239-249.

Muskavitch, M. A. T. (1995). Delta-Notch signalling and Drosophila cell fate choice. Dev Biol. 166: 415-430.

Nakahata, T., Gross, A. J. and Ogawa, M. (1982). A stochastic model of self renewal and commitment to differentiation of the primitive haemopoietic cells in culture. J Cell Physiol. 113: 455-458.

Narisawa, Y., Hashimoto, K. and Kohda, H. (1994). Immunohistochemicasl demonstration of keratin 19 expression in isolated human hair follicles. J Invest Dermatol. 103: 191-195.

Nicholas, J. F., Chamchick, N., Thivolet, J., Wijdenes, J., Morel, P. and Revillard, J. P. (1991). CD4 antibody treatment of severe psoriasis. Lancet. 338: 321. 
Nickoloff, B. J., Nestle, F. O., Zheng, X.-G. and Turka, L. A. (1994). T lymphocytes in skin lesions of psoriasis and mycosis fungoides express B7-1, a ligand for CD28. Blood. 83: 2580-2586.

Nose, A. and Takeichi, M. (1986). A novel cadherin cell adhesion molecule: its expression patterns associated with implantation and organogenesis of mouse embryos. The Journal of Cell Biology. 103: 2649-2658.

O'Keefe, E. J., Briggaman, R. A. and Herman, B. (1987). Calcium-induced assembly of adherens junctions in keratinocytes. The Journal of Cell Biology. 105: 807-817.

Odland, G. F. (1958). The fine structure of the interrelationship of cells in the human epidermis. J Biophys Biochem Cytol. 4: 529-538.

Odland, G. F. (1991). Structure of the skin. Physiology, biochemistry and molecular biology of the skin. Oxford, Oxford University Press. Ed. Goldsmith L. A. 2nd ed. 3-62.

Ogawa, M. (1993). Differentiation and proliferation of hematopoietic stem cells. Blood. 81: 2844-2853.

Otey, C.A., Pavalko, F.M. and Burridge, K. (1990). An interaction between $\alpha$ actinin and the $\beta 1$ integrin subunit in vitro. $\mathrm{J}$ Cell Biol. 111: 721-9.

Overduin, M., Harvey, T. S., Bagby, S., Tong, K. I., Yau, P., Takeichi, M. and Ikura, M. (1995). Solution structure of the epithelial cadherin domain responsible for selective cell adhesion. Science. 267: 386-389.

Palmer, E.L., Ruegg, C., Ferrando, R., Pytela, R. and Sheppard, D. (1993). Sequence and tissue distribution of the integrin $\alpha 9$ subunit, a novel partner of $\beta 1$ that is widely distributed in epithelia and muscle. J Cell Biol. 123: 1289-1297.

Parakkal, P. F. (1969). Ultrastructural changes of the basal lamina during the hair cycle. J Cell Biol. 40: 561-564.

Parkinson, K., Grabham, P. and Emmerson, A. (1983). A subpopulation of human keratinocytes which is resistant to the induction of terminal differentiation -related changes by phorbol, 12-myristate, 13 -acetate: evidence for an increase in the resistant subpopulation following transformation. Carcinogenesis. 4: 857-853.

Parkinson, E. K., Graham, G. J., Daubersies, P., Burns, J. E., Heufler, C., Plumb, M., Schuler, G. and Pragnell, I. B. (1993). Hematopoietic stem-cell inhibitor (sci mip-1- $\alpha$ ) also inhibits clonogenic epidermal keratinocyte proliferation. J Invest Dermatol. 101: 113-117.

Pawley, J. B. and Centrose, V. E. (1994). Practical laser-scanning confocal microscopy. Cell Biology, a laboratory handbook. Ed. Celis, J. E. .San Diego, Academic Press. 44-64.

Peifer, M. and Bejsovec, A. (1992). Knowing your neighbours: cell interactions determine intrasegmental patterning in drosophila. Trends in Genetics. 8: 243-249.

Peifer, M., McCrea, P. D., Green, K. J., Wieschaus, E. and Gumbiner, B. M. (1992). The vertebrate adhesive junction proteins $\beta$-catenin and plakoglobin and the Drosophila segment polarity gene armadillo form a multigene family with similar properties. J Cell Biol. 118: 681-691. 
Peifer, M., Sweeton, D., Casey, M. and Wieshaus, E. (1994). wingless signal and Zeste-white 3 kinase trigger opposing changes in the intracellular distribution of Armadillo. Development. 120: 369-380.

Peifer, M. and Wieschaus, E. (1990). The segment polarity gene armadillo encodes a functionally modular protein that is the drosophila homologue of human plakoglobin. Cell. 63: 1167-1178.

Pellegrini, G., De Luca, M., Orecchia, G., Balzac, F., Cremona, O., Savoia, P., Cancedda, R. and Marchisio, P. C. (1992). Expression, topography, and function of integrin receptors are severely altered in keratinocytes from involved and uninvolved psoriatic skin. J Clin Invest. 89: 1783-1795.

Peltonen, J., Larjava, H., Jaakkola, S., Gralnick, H., Akiyama, S. K., Yamada, S. S., Yamada, K. M. and Uitto, J. (1989). Localization of integrin receptors for fibronectin, collagen, and laminin in human skin. Variable expression in basal and squamous cell carcinomas. J Clin Invest. 84: 1916-1923.

Penneys, N. S., Fulton, J. E., Weinstein, G. D. and Frost, P. (1970). Location of proliferating cells in human epidermis. Arch Dermatol. 101: 323-327.

Pierard-Franchimont, C. and Pierard, G. E. (1989). Stereotyped distribution of proliferating keratinocytes in human epidermis. Am J Dermatopathology. 11: 233237.

Pierce, G. B. and Speers, W. C. (1988). Tumours as caricatures of the process of tissue renewal: prospects for therapy by directing differentiation. Cancer Res. 48: 1996-2004.

Polakowska, R. R. and Goldsmith, L. A. (1991). The cell envelope and transglutaminases. In the Physiology, biochemistry and molecular biology of the skin. Ed. Goldsmith L. A. Oxford, Oxford University Press. 2nd ed. 168-201.

Polakowska, R. R., Piacentini, M., Bartlett, R., Goldsmith, L. A. and Haake, A. R. (1994). Apoptosis in human skin development: morphogenesis, periderm and stem cells. Developmental Dynamics. 199: 176-188.

Potten, C. S. (1974). The epidermal proliferation unit - the possible central role of the basal cell. Cell Tiss Kinet. 7: 77-88.

Potten, C. S. (1975). Epidermal cell production rates. J Invest Dermatol. 65: 488500 .

Potten, C. S. (1976). Identification of clonogenic cells in the epidermis and the structural arrangement of the epidermal proliferative unit (EPU). Stem cells of renewing cell populations. New York, Academic Press. 91-102.

Potten, C. S. (1981). Cell replacement in the epidermis (keratopoiesis) via discrete units of proliferation. Int Rev Cytol. 69: 271-318.

Potten, C. S. and Hendry, J. H. (1973). Clonogenic cells and stem cells in the epidermis. Int J Radiat Biol. 24: 537-540.

Potten, C. S. and Morris, R. J. (1988). Epithelial stem cells in vivo. J Cell Sci Suppl. 10: 45-62. 
Potts, J. R. and Campbell, I. R. (1994). Fibronectin structure and assembly. Current Opinion in Cell Biology. 6: 648-655.

Pringle, J. H., Ruprai, A. K., Primrose, L., Keyte, J., Potter, L., Close, P. and Lauder, I. (1990). In situ hybridisation of immunoglobulin light chain mRNA in paraffin sections using biotinylated or hapten-labelled oligonucleotide probes. J Pathology. 162: 197-207.

Prinz, J., Braun-Falco, О., Meurer, M., Daddona, P., Reiter, C., Rieber, P. and Riethmuller, G. (1991). Chimaeric CD4 monoclonal antibody in treatment of generalised pustular psoriasis. Lancet. 338: 320 .

Prinz, J. C., Gros, B., Vollmer, S., Trommler, P., Strobel, I., Meurer, M. and Plewig, G. (1994). T cell clones from psoriasis skin lesions can promote keratinocyte proliferation in vitro via secreted products. Eur J Immunol. 24: 593598.

Pulkkinen, L., Christiano, A. M., Airenne, T., Haakana, H., Tryggvason, K. and Uitto, J. (1994). Mutations in the gamma 2 chain gene (LAMC2) of kalinin/laminin 5 in the junctional forms of epidermolysis bullosa. Nat Genet. 6: 293-297.

Read, J. and Watt, F. M. (1988). A model for in vitro studies of epidermal homeostasis: proliferation and involucrin synthesis by cultured human keratinocytes during recovery after stripping off the suprabasal layers. J Invest Dermatol. 90: 739-743.

Reily, J. T. and Nash, J. R. (1988). Vitronectin (serum spreading factor): its localisation in normal and fibrotic tissue. J Clin Pathol. 41: 1269-1272.

Reis, A., Hennies, H. C., Langbein, L., Digweed, M., Mischke, D., Drechsler, M., Schrock, E., Royker-Pokora, B. and Franke, W. W. (1994). Keratin 9 gene mutations in epidermolytic palmoplantar keratoderma. Nature Genet. 6: 174-179. Reszka, A. A., Hayashi, Y. and Horwitz, A. F. (1992). Identification of amino acid sequences in the integrin $\beta 1$ cytoplasmic domain implicated in cytoskeletal association. J Cell Biol. 117: 1321-1330.

Rheinwald, J. G. and Green, H. (1977). Epidermal growth factor and the multiplication of cultured human keratinocytes. Nature. 265: 421-424.

Rheinwald, R. (1989). Methods for clonal growth and serial cultivation of normal human epidermal keratinocytes and mesothelial cells. Cell Growth and Division. A Practical Approach. Oxford, IRL Press. 1st, ed. 81-94.

Rheinwald, R. G. and Green, H. (1975). Serial cultivation of strains of human epidermal keratinocytes: the formation of keratinizing colonies from single cells. Cell. 6: 331-344.

Rice, R. H. and Green, H. (1978). Relation of protein synthesis and transglutaminase activity to formation of the cross-linked envelope during terminal differentiation of the cultured human keratinocyte. J Cell Biol. 76: 705-711.

Rice, R. H. and Green, H. (1979). Presence in human epidermal cells of a soluble protein precursor of the cross-linked envelope: activation of the cross-linking by calcium ions. Cell. 18: 681-694.

Roberts, D. and Marks, R. (1980). The determination of regional and age variations in the rate of desquamation: A comparison of four techniques. J Invest Dermatol. 74: 13-16. 
Rochat, A., Kobayashio, K. and Barrandon, Y. (1994). Location of stem cells of human hair follicles by clonal analysis. Cell. 76: 1063-1073.

Rodriguez, I. R. and Chadre, G. J. (1992). A novel method for the ioslation of tissue specific genes. Nucleic Acids Research. 20: 3528.

Rousselle, P. and Aumailley, M. (1994). Kalinin is more efficient than laminin in promoting adhesion of primary keratinocytes and some other epithelial cells and has a different requirement for integrin receptors. J Cell Biol. 125: 205-214.

Rousselle, P., Lunstrum, G. P., Keene, D. R. and Burgeson, R. E. (1991). Kalinin: an epithelium-specific basement membrane adhesion molecule that is a component of anchoring filaments. J Cell Biol. 114: 567-576.

Ryan, T. J. (1991). Cutaneous circulation. In Physiology, biochemistry and molecular biology of the skin. Ed Goldsmith L.A. Oxford, Oxford University Press. 2nd ed. p1019-1084.

Ryynanen, M., Ryynanen, J., Sollberg, S., Iozzo, R. V., Knowlton, R. G. and Uitto, J. (1992). Genetic linkage of type VII collagen (COL7A1) to dominant dysplastic epidermolysis bullosa in families with abnormal anchoring fibrils. J Clin Invest. 89: 974-980.

Salzman, G. C., Crowell, J. M., Martin, J. C., Trujillo, T. T., Romero, A., Mullaney, P. F. and LaBauve, P. M. (1975). Cell classification by Laser Light Scattering: Identification and Separation of Unstained Leucocytes. Acta Cytologia. 19:

Salzman, G. C., Mullaney, P. F. and Price, B. J. (1979). Light scattering approaches to cell characterization. Flow Cytometry and Sorting. New York, John Wiley. 105-124.

Sambrook, J., Fritsch, E. F. and Maniatis, T. (1989). Molecular cloning- a laboratory manual. Cold Spring Habour Laboratory Press.

Sargent, T. D. (1987). Isolation of differentially expressed genes. Guide to molecular cloning techniques. San Diego, Academic Press. 423-432.

Schaller, M. D., Borgman, C. A., Cobb, B. S., Vines, R. V., Reynolds, A. B. and Parsons, J. T. (1992). pp125FAK, a structurally distinctive protein-tyrosine kinase associated with focal adhesions. Proc Natl Acad Sci USA. 89: 5192-5196.

Schaller, M. D. and Parsons, J. T. (1994). Focal adhesion kinase and associated proteins. Curr Opinion in Cell Biol. 6: 705-710.

Scheving, L. E. (1959). Mitotic activity in the human epidermis. Anatomical Record. 135: 7-14.

Schlaepfer, D. D., Hanks, S. K., Hunter, T. and van der Geer, P. (1994). Integrin mediated signal transduction linked to Ras pathway by GRB2 binding to focal adhesion kinase. Nature. 372: 786-791. 
Schmidt, G. H., Blount, M. A. and Ponder, B. A. (1987). Immunochemical demonstration of the clonal organisation of mouse epidermis. Development. 100: 535-541.

Schwartz, M. A., Owaribe, K., Kartenbeck, J. and Franke, W. W. (1990). Desmosomes and hemidesmosomes: constitutive molecular components. Ann Review Cell Biol.

Schwartzbauer, J. E. (1991). Identification of the fibronectin sequences required for assembly of a fibrillar matrix. J Cell Biol. 113: 1463-1473.

Scothorne, R. J. and Hunter, J. A. A. (1981). Structure and function of skin. In $\underline{A}$ companion to medical studies. Oxford, Blackwell Scientific Publications. 3, ed.

Sellheyer, K., Bickenbach, J. R., Rothnagel, J. A., Bundman, D., Longley, M. A., Krieg, T., Roche, N. S., Roberts, A. B. and Roop, D. R. (1993). Inhibition of skin development by overexpression of transforming growth factor $\beta 1$ in transgenic mice. Proc Natl Acad Sci USA. 90: 5237-5241.

Setoguchi, Y., Jaffe, A.H., Danel, C. and Crystal, R.G. (1994). Ex vivo and in vivo gene transfer to the skin using replication-deficient recombinant adenovirus vectors. J Invest Dermatol. 102: 415-421.

Shih, D. T., Edelman, J.M., Horwitz, A.F., Grunwald, G.B. and Buck, C.A. (1993). Structure/function analysis of the integrin $\beta 1$ subunit by epitope mapping. $J$ Cell Biol. 122: 1361-1371.

Shimoyama, Y., Hirohashi, S., Hirano, S., Nogushi, M., Shimosato, Y., Takeichi, M. and Abe, O. (1989). Cadherin cell-adhesion molecules in human epithelial tissues and carcinomas. Cancer Research. 49: 2128-2133.

Simon, M. (1994). The epidermal cornified envelope and its precursors. In The keratinocyte handbook. Eds Leigh, I. M., Lane, E. B. and Watt, F. M. Cambridge, Cambridge University Press. p 275-292.

Simon, M. and Green, H. (1984). Participation of membrane-associated proteins in the formation of the cross-linked envelope of the keratinocyte. Cell. 36: 827-34.

Shipley, G. T., Pittelkow, M. R., Wille, J. J. J., Scott, R. E. and Moses, H. L. (1986). Reversible inhibition of normal human prokeratinocyte proliferation by type beta transforming growth factor-growth inhibitor in serum free medium. Cancer Res. 46: 2068-2071.

Sklar, L.A., Omann, G. M. and Painter, R. G. (1985). Relationship of actin polymerisation and depolymerisation to light scattering in human neutrophils: Dependence on receptor occupancy and intracellular $\mathrm{Ca}^{++}$. J Cell Biol. 101: 11611166.

Sollberg, S., Peltonen, J. and Uitto, J. (1992). Differential expression of laminin isoforms and b4 integrin epitopes in the basement membrane zone of normal human skin and basal cell carcinomas. J Invest Dermatol. 98: 864-870.

Sonnenberg, A., de Melker, A. A., de Velasco, A. M. M., Janssen, H. and Calafat, J. (1993). Formation of hemidesmosomes in cells of a transformed murine mammary tumor cell line and mechanisms involved in adherence of these cells to laminin and kalinin. J Cell Sci. 106: 1083-1 102. 
Sonnenberg, A., Linders, C. J. T., Daams, J. H. and Kennel, S. J. (1986).

Development of mouse mammary gland: identification of stages in differentiation of luminal and myoepithelial cells using monoclonal antibodies and polyvalent serum against keratin. J Histochem Cytochem. 34: 1037-1046.

Spangrude, G. J., Heimfeld, S. and Weissman, I. L. (1988). Purification and Characterisation of Mouse Hematopoietic Stem Cells. Science. 241: 58-62.

Stanley, J. R. (1995). Autoantibodies against adhesion molecules and structures in blistering skin diseases. J Exp Med. 181: 1-4.

Stanley, J. R., Foidart, J.-M., Murray, J. C., Martin, G. R. and Katz, S. I. (1980). The epidermal cell which adheres selectively to collagen substrate is the basal cell. J Invest Dermatol. 74: 54-58.

Stasiak, P. C., Purkis, P. E., Leigh, I. M. and Lane, E. B. (1989). Keratin 19: predicted amino acid sequence and broad tissue distribution suggests it evolved from keratinocyte keratins. J Invest Dermatol. 92: 707-716.

Stepp, M. A., Spurr, M. S., Tisdale, A., Elwell, J. and Gipson, I. K. (1990). $\alpha 6 \beta 4$ integrin heterodimer is a component of hemidesmosomes. Proc Natl Acad Sci U S A. 87: 8970-4.

Strange, P., Cooper, K. D., Hansen, E. R., Fisher, G., Larsen, J. K., Fox, D., Krag, C., Voorhees, J. J. and Baadsgaard, O. (1993). T-lymphocyte clones initiated from lesional psoriatic skin release growth factors that induce keratinocyte proliferation. J Invest Dermatol. 101: 695-700.

Suda, T., Suda, J. and Ogawa, M. (1984). Disparate differentiation in mouse hemopoietic colonies derived from paired progenitors. Proc Natl Acad Sci USA. 81: 2520-2524.

Sun, T. T. and Green, H. (1978). Immunofluorescent staining of keratin fibres in cultured cells. Cell. 14: 469-76.

Suzuki, S. and Naitoh, Y. (1990). Amino acid sequence of a novel integrin $\beta 4$ subunit and primary expression of the mRNA in epithelial cells. EMBO J. 9: 75763.

Symington, B.E., Takada,Y. and Carter, W.G. (1993). Interaction of integrins $\alpha 3 \beta 1$ and $\alpha 2 \beta 1$ : potential role in keratinocyte intercellular adhesion. J Cell Biol. 120: $523-535$.

Tamura, R. N., Rozzo, C., Starr, L., Chambers, J., Reichardt, L. F., Cooper, H. M. and Quaranta, V. (1990). Epithelial integrin $\alpha 6 \beta 4$ : complete primary structure of $\alpha 6$ and variant forms of $\beta 4$. J Cell Biol. 111: 1593-1604.

Temple, S. and Raff, M. C. (1986). Clonal analysis of oligodendrocyte differentiation in culture; evidence for a developmental clock that counts cell divisions. Cell. 44: 773-779.

Tenchini, M. L., Adams, J. C., Gilbert, C., Steel, J., Hudson, D. L., Malcovati, M. and Watt, F. M. (1993). Evidence against a major role for integrins in calciumdependent intercellular adhesion of epidermal keratinocytes. Cell Adhesion and Communication. 1: 55-66. 
Tharp, M. D. (1991). The mast cell and its mediators. In . Physiology, biochemistry and molecular biology of the skin. Ed. Goldsmith L.A.Oxford, Oxford University Press. 2nd ed. p1099-1120.

Thomas, T. and Dziadek, M. (1993). Genes coding for basement membrane glycoproteins laminin, nidogen and collagen IV are differentially expressed in the nervous system and by epithelial, endothelial and mesenchymal cells of the mouse embryo. Exp Cell Res. 208: 54-67.

Thuringer, J. M. (1928). Studies on cell division in the human epidermis. Anat Rec. 40: 1-13.

Tidman, M. J. and Eady, R. A. J. (1985). Evaluation of anchoring fibrils and other components of dermo-epidermal junction in dystrophic epidermolysis bullosa by a quantitative ultrastructural technique. J Invest Dermatol. 84: 374-377.

Till, J. E. and McCulloch, E. A. (1961). A direct measurement of the radiation sensitivity of normal bone marrow cells. Radiation Res. 14: 213-222.

Till, J. E., McCulloch, E. A. and Siminovitch, L. (1964). A stochastic model of stem cell proliferation based on the growth of spleen colony forming cells. Proc Natl Acad Sci USA. 51: 29-36.

Toda, K. and Grinnell, F. (1987). Activation of human keratinocyte fibronectin receptor function in relation to other ligand-receptor interactions. J Invest Dermatol. 88: $412-417$.

Turner, C. E. and Burridge, K. (1991). Transmembrane molecular assemblies in cell-extracellular matrix interactions. Curr Opinion Cell Biol. 3: 849-853.

Utans, U., Liang, P., Wyner, L. R., Karnovsky, M. J. and Russell, M. E. (1994). Chronic cardiac rejection: identification of five upregulated genes in transplanted hearts by differential mRNA display. Proc Natl Acad Sci USA. 91: 6463-6467.

Van den Born, J., Van den Heuval, L. P. W. J., Bakker, M. A. H., Veerkamp, J. H., Assmann, J. M. and Berden, J. H. M. (1994). Monoclonal antibodies against the protein core and glycosaminoglycan side chain of glomerular basement membrane heparan sulfate proteoglycan: characterisation and immunohistological application to human tissues. J Histochem Cytochem. 42: 89-102.

Vassar, R., Coulombe, P. A., Degenstein, L., Albers, K. and Fuchs, E. (1991). Mutant keratin expression in transgenic mice causes marked abnormalities resembling a human genetic skin disease. Cell. 64: 365-80.

Verrando, P., Blanchet-Bardon, C., Pisani, A., Thomas, L., Cambazard, F., Eady, R. J., Schofield, O. and Ortonne, J.-P. (1991). Monoclonal antibody GB3 defines a widespread defect of several basement membranes and a keratinocyte dysfunction in patients with lethal junctional epidermolysis bullosa. Lab Invest. 64: 85-91.

Verrando, P., Pisani, A. and Ortonne, J.-P. (1988). The new basement membrane antigen recognised by the monoclonal antibody GB3 is a large size weight glycoprotein: modulation of its expression by retinoic acid. Biochim Biophys Acta. 942: 45-56. 
Ward, G. K., Stewart, S. S., Price, G. B. and Mackillop, W. J. (1986). Cellular heterogeneity in Normal Human Urothelium: An analysis of optical properties and lectin binding. J Histochem Cytochem. 34: 841-846.

Watt, F. M. (1993a). Human epidermal keratinocytes in culture: Role of integrins in regulating adhesion and terminal differentiation. Molecular basis of morphogenesis. New York, Wiley-Liss. 241-254.

Watt, F. M. (1993b). Involucrin and other markers of keratinocyte terminal differentiation. J Invest Dermatol. 81, Supplement: 100s-103s.

Watt, F. M. (1994a). Cultivation of human epidermal keratinocytes with a 3T3 feeder layer. Cell Biology, a laboratory handbook. Academic Press. p83-89.

Watt, F. M. (1994b). Suspension induced differentiation of keratinocytes. Keratinocyte Methods. Eds Leigh, I. M., Lane, E. B. and Watt, F. M. Cambridge, Cambridge University Press. p113.

Watt, F. M. and Green, H. (1981). Involucrin Synthesis is Correlated with Cell Size in Human Epidermal Cultures. J Cell Biol. 90: 738-742.

Watt, F. M. and Green, H. (1982). Stratification and terminal differentiation of cultured human cells. Nature, Lond. 295: 434-436.

Watt, F. M. and Jones, P. H. (1992). Changes in cell surface carbohydrate during terminal differentiation of human epidermal keratinocytes. Biochem Soc Trans. 20: 285-288.

Watt, F. M. and Jones, P. H. (1993). Expression and function of the keratinocyte integrins. Development. 1993 Supplement: 185-192.

Watt, F. M., Jordan, P. W. and O'Neill, C. H. (1988). Cell shape controls terminal differentiation of human epidermal keratinocytes. Proc Natl Acad Sci U S A. 85: 5576-5580.

Watt, F. M., Mattey, D. L. and Garrod, D. R. (1984). Calcium-induced reorganisation of desmosomal components in cultured human keratinocytes. J Cell Biol. 99: 2211-2215.

Watt, F. M., Reichelt, K. L. and Elgjo, K. (1989). Pentapeptide inhibitor of epidermal mitosis: production and responsiveness in cultures of normal, transformed and neoplastic human keratinocytes. Carcinogenesis. 10: 2249-53.

Weinstein, G. D. and Mooney, K. (1980). Cell proliferation in the human hair root. J Invest Dermatol. 50: 245-249.

Werb, Z., Tremble, P. M., Behrendtsen, O., Crowley, E. and Damsky, C. H. (1989). Signal transduction through the fibronectin receptor induces collagenase and stromelysin gene expression. J Cell Biol. 109: 877-89.

Wertz, P. W. and Downing, D. (1991). Epidermal lipids. In Physiology, biochemistry and molecular biology of the skin. Ed Goldsmith L.A. Oxford, Oxford University Press. 2nd ed. p205-236.

White, J. G., Amos, W. B. and Fordham, M. (1987). An evaluation of the confocal versus conventional imaging of biological structures by fluorescence light microscopy. J Cell Biol. 105: 41-48. 
Williams, D. A., Rios, M., Stephens, C. and Patel, V. P. (1991). Fibronectin and VLA-4 in haematopoietic stem cell-microenvironment interactions. Nature. 352: 438-441.

Wilson (1896). The cell in development and inheritance. New York, Macmillan.

Wilson (1927). The cell in development and inheritance. New York, Macmillan.

Withers, H. R. (1967). Recovery and repopulation in vivo by the mouse skin epithelial cells during fractionated irradiation. Radiat Res. 32: 227-239.

Wong, D. T. W., Chou, M. Y., Chang, L.-C. and Gallagher, G. T. (1990). Use of intracellular $\mathrm{H} 3$ messenger RNA as a marker to determine the proliferation of normal and 7,12-dimethylbenz[a]anthracence transformed hampster oral epithelium. Caner Res. 50: 5107-5111.

Wright, N. A. and Alison, M. (1984). The biology of epithelial cell populations. Oxford, Clarendon Press.

Wyllie, A. H. (1980). Glucocorticoid-induced thymocyte apoptosis is associated with endogenous nuclease activation. Nature. 284: 555-556.

Yang, Y. S., Lavker, R. M. and Sun, T.-T. (1993). Upper human hair follicle contains a subpopulation of keratinocytes with superior in vitro proliferative potential. J Invest Dermatol. 101: 652-659.

Yanai, N., Sekine, C., Yagita, H. and Obinata, M. (1994). Roles for integrin very late activation antigen-4 in stroma-dependant erythropoiesis. Blood. 83: 22842850 .

Yoshioka, K., Hino, S., Takemura, T., Maki, S., Wieslander, J., Takekoshi, Y., Makino, H., Kagawa, M., Sado, Y. and Kashtan, C. E. (1994). Type IV collagen alpha 5 chain. Normal distribution and abnormalities in X-linked Alport syndrome revealed by monoclonal antibody. Am J Pathol. 144: 986-96.

Young, B. D. and Anderson, M. L. M. (1985). Quantitative analysis of solution hybridisation. Nucleic acid hybridisation - a practical approach. Oxford, IRL Press. 47-71.

Yurchenco, P. D. and Furthmayer, H. (1984). Self assembly of basement membrane collagen. Biochemistry. 23: 1839-1850.

Yurchenco, P. D. and O'Rear, J. J. (1994). Basal lamina assembly. Current Opinion in Cell Biology. 6: 674-681.

Yurchenco, P. D. and Schittney, J. C. (1990). Molecular architecture of basement membranes. FASEB J. 4: 1577-1590.

Yurcheno, P. D., Cheng, Y. and Colognato, H. (1992). Laminin forms an independant network in basement membranes. J Cell Biol. 117: 1119-1133.

Zhong, R., Roeder, R. G. and Heintz, N. (1983). The primary structure and expression of four cloned human histone genes. Nucleic Acid Res. 11: 7409-7425.

Ziegler, A., Jonason, A. S., Leffel, D. J., Simon, J. A., Sharma, H. W., Kimmelman, J., Remington, L., Jacks, T. and Brash, D. E. (1994). Sunburn and p53 in the onset of skin cancer. Nature. 372: 773-776. 
Zimmermann, D. R., Dours-Zimmermann, M. T., Schubert, M. and BrucknerTuderman, L. (1994). Versican is expressed in the proliferating zone in the epidermis and in association with the elastic network of the dermis. J Cell Biol. 124: 817-825. 